\title{
Site U1324
}

\author{
Expedition 308 Scientists $^{2}$
}

\section{Chapter contents}

Background and objectives. . . . . . . . 1

Summary of operations. .............2

Lithostratigraphy.............4

Biostratigraphy . . . . . . . . . . .

Paleomagnetism ................ 11

Geochemistry and microbiology. . . . . . . 12

Physical properties .............. 14

Downhole measurements............. 17

References...................24

Figures................. 25

Tables. . . . . . . . . . . . . . . . . . . . . 107

'Expedition 308 Scientists, 2006. Site U1324. In Flemings, P.B., Behrmann, J.H., John, C.M., and the Expedition 308 Scientists, Proc. IODP, 308: College Station TX (Integrated Ocean Drilling Program Management International, Inc.). doi:10.2204/iodp.proc.308.108.2006

'Expedition 308 Scientists' addresses.

\section{Background and objectives Geological setting of Mars-Ursa Basin}

The geological framework of Mars-Ursa Basin is treated in detail in the "Site U1322" chapter. The reader is referred to this chapter regarding detailed background information, and a more extensive compilation of the data available before drilling operations began (Figs. F1, F2, F3, F4 in the "Site U1322" chapter; Table T1 in the "Site U1322" chapter).

\section{Overview of seismically mapped surfaces}

Site U1324 is the westernmost of the sites drilled in Ursa Basin during Expedition 308 (see Figs. F2, F3 in the "Site U1322" chapter), is at the shallowest water depth (1057 meters below sea level [mbsl]), and has the deepest sediment penetration (612 meters below seafloor [mbsf]). It is located within Mississippi Canyon Lease Block 897. Eight seismic surfaces are mapped along the Ursa Basin transect (Fig. F1; see also Fig. F4 and Table T1 in the "Site U1322" chapter). Among those, seismic Reflectors S10, S20, S30, and S80 are regional surfaces that span all three drill sites. Seismic Reflector S10 at $1458 \mathrm{~ms}$ two-way traveltime (TWT) (35 mbsf) represents the probable base of the hemipelagic drape sediments. Seismic Reflector S20 at 1548 ms TWT (105 mbsf) separates distal levee muds from the underlying fine-grained clastics of the eastern Southwest Pass Canyon levee. Seismic Reflector S30 (1623 ms TWT; $165 \mathrm{mbsf}$ ) is a detachment surface that underlies one of the mass transport deposits (MTDs). Between seismic Reflectors S30 and S60-1324 (2136 ms TWT; $612 \mathrm{mbsf}$ ) horizontal parallel reflectors alternate with chaotic zones. The top of the Blue Unit (S80) is delineated by a weak, negative polarity reflector of irregular geometry $20 \mathrm{~ms}$ TWT beneath the terminal depth (TD) of Holes U1324A and U1324B.

\section{Local summary of borehole expectations}

Latest Pleistocene to Holocene sedimentation at Site U1324 is characterized (from youngest to oldest) by a hemipelagic drape underlain by a packet of muddy sediments belonging to distal levee deposits. Beneath this, the deposits of the eastern levee of Southwest Pass Canyon are underlain by sediments belonging to the western levee of Ursa Canyon. The Ursa Canyon levee deposits cut into the underlying sand-dominated Blue Unit (Fig. F1; see also Fig. F4 in the "Site U1322" chapter). 


\section{Drilling objectives}

The primary drilling objectives at this site were the following:

- Characterize temperature and pressure as a function of depth in this part of the Ursa Basin sediment wedge.

- Characterize porosity and other key physical and geotechnical properties as a function of depth.

- Elucidate controls on slope stability, especially in the slumped lithostratigraphic intervals.

- Understand the timing of hemipelagic and muddy turbidite background sedimentation and the slumping events.

- Characterize lithology and depositional processes within the Southwest Pass canyon and Ursa channelized turbidite systems.

To fully achieve these objectives, Hole U1324B was continuously cored to TD at 608 mbsf. Advanced piston coring (APC) was used to $357.90 \mathrm{mbsf}$, followed by extended core barrel (XCB) coring to $368 \mathrm{mbsf}$. From there, further APC coring was carried out to 394.50 mbsf, again followed by XCB coring to TD. Special tool deployments included five deployments of the temperature/dual pressure (T2P) probe and seven deployments of the Davis-Villinger Temperature-Pressure Probe (DVTPP). Before coring operations, a dedicated hole (Hole U1324A) was drilled to conduct logging-while-drilling/measurement-whiledrilling (LWD/MWD) operations to a TD of 612 mbsf. This was followed by wireline logging and a vertical seismic profile to generate a complete set of logging parameters for correlation with core data and observations from Hole U1324A. After coring in Hole U1324B, a dedicated third hole (Hole U1324C) was drilled to 511.8 mbsf in order to obtain additional temperature and pressure measurements, followed by one spot core at each measurement station. There were five T2P probe and three DVTPP deployments in Hole U1324C.

\section{Summary of operations}

\section{Hole U1324A}

A summary of operations in Hole U1324A is found in Table T1. A beacon was deployed at Site U1324 at $1040 \mathrm{~h}$ on 17 June 2005 . Hole U1324A was spudded at $1610 \mathrm{~h}$ when the driller tagged the seafloor at 1066.0 meters below rig floor (mbrf) (precision depth recorder $[\mathrm{PDR}]=1078.0 \mathrm{mbrf})$. After the bit was washed ahead to $5.0 \mathrm{mbsf}$, MWD drilling advanced without incident to $333.4 \mathrm{mbsf}$ at a rate of penetration (ROP) of $30 \mathrm{~m} / \mathrm{h}$, where a wiper trip was made back to 60.8 mbsf. MWD drilling resumed to 477.7 mbsf, where another wiper trip was made back to
330.4 mbsf. Because of the potential for interbedded levee sands below 481 mbsf, we used heavy mud from this depth to the TD of $612 \mathrm{mbsf}$ ( $20 \mathrm{~m}$ above the top of the Blue Unit). At $\sim 2045 \mathrm{~h}$ on 18 June, MWD drilling advanced slowly at an ROP of $20 \mathrm{~m} / \mathrm{h}$, gradually increasing to $30 \mathrm{~m} / \mathrm{h}$ while "pumping and dumping" $10.0 \mathrm{ppg}$ mud. Drilling advanced to the depth objective of 612 mbsf by $0410 \mathrm{~h}$ the next morning. The hole was plugged with cement and heavy mud and abandoned. A free-fall funnel (FFF) was made up and deployed at $0808 \mathrm{~h}$ on 19 June with the bit at $\sim 80$ mbsf. The vibration-isolated television (VIT) camera was deployed and a visual inspection confirmed that there was no flow emanating from the top of the FFF and that the funnel was upright. The bit was pulled free of the seafloor at $0853 \mathrm{~h}$. It was decided in view of the good hole conditions that wireline logging should be attempted in Hole U1324A. A logging/cementing bottom-hole assembly (BHA) was made up with the $97 / 8$ inch polycrystalline diamond bit, bit, bit sub, controlledlength drill collar (CLDC), modified top sub, four CLDCs, tapered drill collar, six joints of $5 \frac{1}{2}$ inch drill pipe, and a crossover sub (length $=116.6 \mathrm{~m}$ ). The second reentry of the expedition was made at $1828 \mathrm{~h}$ on 19 June, and the bit placed at the logging depth of 54.2 mbsf. A tool string consisting of the Hostile Environment Gamma Ray Sonde (HNGS), Dipole Sonic Imager (DSI), and General Purpose Inclinometer Tool (GPIT) was deployed. A more detailed description of wireline logging and LWD/MWD operations in Hole U1324A can be found in "Downhole measurements."

\section{Hole U1324B}

A summary of operations in Hole U1324B is found in Table T2. The BHA was reconfigured to an APC/XCB array by replacing two of the CLDCs with a seal bore drill collar and nonmagnetic drill collar. This array was identical to the BHA used to core the BrazosTrinity sites. After a VIT camera survey of the seafloor, the driller tagged the bottom at $1066.8 \mathrm{mbrf}$. Hole U1324B was spudded with the APC at $0250 \mathrm{~h}$ on 21 June 2005 . The recovery of the first core established the seafloor depth at 1067.5 mbrf. Piston coring advanced without incident to $17.8 \mathrm{mbsf}$, where the corer did not achieve a complete stroke but did recover $9.91 \mathrm{~m}$ (recovery $=104 \%)$. APC coring continued to 357.9 mbsf by advancing by recovery. We observed that downhole pressure measurements from the previous day indicated pressures below hydrostatic, and the readings were consistent between both the T2P probe and the DVTPP. Comparing these abnormal readings with the deformation seen at the base of the APC cores, it was inferred that the suction applied to retrieve the piston cores may have 
deformed the material sufficiently to influence pressure readings in the formation. Hence, one XCB core was obtained prior to a deployment of the DVTPP and $\mathrm{T} 2 \mathrm{P}$ probe. However, $\mathrm{XCB}$ coring did not improve pressure measurements; the subhydrostatic pressure readings continued to afflict most of the subsequent DVTPP measurements up to the eighth run in the hole. Just prior to the eighth measurement, a small interior leak in the DVTPP unit was discovered and repaired. This fixed the problem.

Piston coring continued to a TD of 394.5 mbsf by advancing by recovery. A total of 48 piston cores were shot in order to penetrate to this depth, and the average recovery was $101.3 \%$. Nonmagnetic core barrels were used for all piston cores. The cores were oriented starting with Core $4 \mathrm{H}$. The APC temperature (APCT) tool was deployed at Cores $6 \mathrm{H}, 9 \mathrm{H}, 12 \mathrm{H}$, and $15 \mathrm{H}$ (see Tables T2, T16). Fluorescent microspheres were deployed in the core catchers of Cores $1 \mathrm{H}-11 \mathrm{H}$, $13 \mathrm{H}, 15 \mathrm{H}, 17 \mathrm{H}, 19 \mathrm{H}, 21 \mathrm{H}-23 \mathrm{H}, 26 \mathrm{H}, 29 \mathrm{H}-32 \mathrm{H}, 35 \mathrm{H}$, $38 \mathrm{H}-41 \mathrm{H}, 44 \mathrm{H}, 47 \mathrm{H}$, and $50 \mathrm{H}$ (see Table T2). The Fugro cutting shoe that was sent out on the work boat was deployed on Cores $4 \mathrm{H}$ and $7 \mathrm{H}$ and odd-numbered piston cores up to and including Core $49 \mathrm{H}$ (see Table T2).

Coring resumed with the $\mathrm{XCB}$ and deepened the hole to 608.2 mbsf. The XCB-cored portion of the hole was $223.8 \mathrm{~m}$ (average recovery $=80.8 \%$ ). The total cored interval was $608.2 \mathrm{~m}$ (average recovery = 93.7\%). In compliance with the operational protocol, heavy mud (10.5 ppg) was continuously pumped starting at 481 mbsf until the bottom of the hole. Fluorescent microspheres were deployed in 10 XCB cores: 53X, 56X, 59X, 62X, 64X, 66X, 68X, 70X, 72X, and 74X (see Table T2).

When drill pipe connections were made to recover or deploy tools or core barrels, the heavy mud would "U-tube," creating a large air gap in the pipe. The impact of the core barrel at the top of the mud level in the pipe tended to shatter the core liner as a result of the sudden deceleration. To avoid this, the core barrels were lowered on the coring line and then intentionally jarred and released by the core winch operator after the barrel landed. The sinker bars were then removed from the drill string to prevent oil saver leakage from spraying mud over the rig floor and derrick. Once the core was cut, the sinker bars were stabbed and the core barrel recovered. This resulted in two coring line roundtrips for each core.

The DVTPP was deployed 10 times in this hole (229.1, 362.4, 387.9, 464.3, 493.1, 522.0, 541.2, $560.4,589.2$, and $608.3 \mathrm{mbsf}$ ) (see Table T16). The pressure data prior to DVTPP Deployment 8 were not usable. The T2P probe was deployed 10 times $(\sim 30$ min each; $51.3,89.3,117.8,136.3,368.0,394.5$, and $593.2 \mathrm{mbsf})$. Because of deployment and electronic problems, none of the data obtained from the T2P in this hole were usable. It was observed that an additional benefit of filling the hole with heavy mud made DVTPP and T2P deployments easier because the tools and BHA became easier to extract from the bottom of the hole after sustained periods without rotation during the deployment process.

Because it was not possible to measure the equivalent circulating density (ECD) of the mud, as was effectively done in Hole U1324A, the conservative measure of pumping $10.5 \mathrm{ppg}$ mud was adopted. The mud engineer calculated that we expended $3880 \mathrm{bbl}$ of $10.5 \mathrm{ppg}$ mud while drilling this hole. In accordance with the operating protocol, the hole was plugged with $44 \mathrm{bbl}$ of $11.0 \mathrm{ppg}$ neat cement, forming a plug of $\sim 145 \mathrm{~m}$. The cement was followed by $40 \mathrm{bbl}$ of $10.5 \mathrm{ppg}$ mud and then chased with $50 \mathrm{bbl}$ of seawater. The hole was observed using the VIT camera with the bit at $\sim 80 \mathrm{mbsf}$ and no flow was detected. The bit was pulled free of the hole at $0025 \mathrm{~h}$ on 26 June. As the vessel was moved off location, a subsea release dart was pumped down to swab the inside of the pipe. This was followed by extensive seawater flushing of the drill string.

\section{Hole U1324C}

A summary of operations in Hole U1324C is found in Table T3. The vessel was repositioned $20 \mathrm{~m}$ west of Hole U1324A in dynamic positioning (DP) mode. After a VIT camera survey of the seafloor indicated no obstructions, Hole U1324C was spudded when the driller tagged the seafloor at 1066.5 mbrf. The hole was then drilled ahead to 50.0 mbsf, where the T2P probe was deployed with good results. Following the retrieval of the probe, a single APC core was obtained for physical property analyses. Following this procedure, three more T2P deployments were made at 100, 150.0, and 200.0 mbsf, each measurement followed by a single APC core. The hole was then drilled to 250.0 mbsf, where a DVTPP measurement was made, followed by a single piston core. Once again the hole was drilled from 250.0 to $300.0 \mathrm{mbsf}$, where the fourth T2P deployment was made, followed by a single APC core. The hole was then drilled to 405.0 and $505.0 \mathrm{mbsf}$, followed each time by a single piston core. The last piston cored advanced to a TD of $511.8 \mathrm{mbsf}$. When the driller advanced beyond 481.0 mbsf, heavy mud (10.5 ppg) was continuously pumped in accordance with the operating protocol for this site. A total of eight piston cores were obtained, the last seven were advanced by recovery. The cored interval was $55.1 \mathrm{~m}$ (average recovery $=100.9 \%$ ). The cores were not oriented and were all obtained with the nonmagnetic core barrel. The Fugro cutting shoe was deployed on even-numbered core barrels. Before the drill string 
was withdrawn from Hole U1324C, the hole was observed with the VIT camera and no flow was evident. Because penetration in the hole was terminated above the sand layers, it was not necessary to plug this hole with cement. The bit was pulled free of the seafloor at $0135 \mathrm{~h}$ on 28 June and positioned $204 \mathrm{~m}$ above the seafloor. The vessel was then offset in DP mode to Site U1322. The beacon was recovered before departing location at $0240 \mathrm{~h}$.

\section{Lithostratigraphy}

Drilling at Site U1324 penetrated Ursa Basin where the sediments above the Blue Unit are thicker than either to Site U1323 or Site U1322. Hole U1324B sampled the entire eastern levee deposits of the Southwest Pass Canyon channel-levee system and the overlying hemipelagic drape and distal turbidites of younger channel-levee systems (Fig. F4 in the "Site U1322" chapter). Sediment was recovered to 608 mbsf in Hole U1324B using APC and XCB coring with overall recovery $>90 \%$. The TD of 608 mbsf ties closely with seismic Reflector S60-1324, the top of the Ursa Canyon western levee. Therefore, sediment recovered at Site U1324 records the entire evolution of the eastern levee of Southwest Pass Canyon. Hole U1324C was spot-cored with the APC between 0 and 511.8 mbsf (Cores 308-U1324C-1H to 7H), but these cores were used primarily for geotechnical wholeround samples and were not used to define lithostratigraphic units.

The sedimentary succession at Site U1324 is dominated by clay and mud in the upper $360 \mathrm{~m}$ and by interbedded silt, sand, and mud in the lower $250 \mathrm{~m}$. Thus, we divided the succession into two lithostratigraphic units based on this distinction (Table T4). Both units were further divided into subunits based on the occurrence of intervals composed of contorted and faulted sediment and intervals composed of undeformed sediment.

Cores $308-\mathrm{U} 1324 \mathrm{~B}-4 \mathrm{H}$ to $44 \mathrm{H}$ were oriented, which allowed for detailed measurements of inclination and orientation of faults and dip of bedding planes (Table T5). Figure F2 summarizes the lithostratigraphic column, and Figures F3, F4, F5, F6, F7, F8, F9, F10, F11, F12, F13, F14, and F15 illustrate the range of features and variations in each of the lithostratigraphic units and subunits.

\section{Description of lithostratigraphic units}

\section{Unit I}

Interval: Sections 308-U1324B-1H-1, 0 cm, through $46 \mathrm{X}-2,75 \mathrm{~cm}$

Depth: 0-364.7 mbsf
Age: Holocene/late Pleistocene

Lithology: clay and mud

Lithostratigraphic Unit I extends from the seafloor to 364.7 mbsf and includes seven subunits (IA-IG). Lithostratigraphic Unit I is predominantly composed of terrigenous clay and mud with a marked paucity of silt and sand. Subunit divisions are based on the observation of distinct intervals composed of contorted and faulted sediment. Other than this distinction, the lithology throughout Unit I is very similar. The base of lithostratigraphic Unit I is defined as the top of a silt bed at 364.7 mbsf, marking a fundamental change in lithology to interbedded silt and very fine sand below, characteristic of lithostratigraphic Unit II.

\section{Subunit IA (0.0-43.9 mbsf)}

Lithostratigraphic Subunit IA is $43.9 \mathrm{~m}$ thick and is composed primarily of olive-green and reddish brown clay interbedded with centimeter- to decimeter-thick thin beds and laminae of black clay. Black clay is organic rich and shows transitions from black at the base to greenish gray at the top. The uppermost $0.38 \mathrm{~m}$ of this subunit is rich in nannofossils and foraminifers (Fig. F3). The base at 43.9 mbsf is marked by a fault that offsets parallel bedding surfaces (Table T5; Fig. F4A).

\section{Subunit IB (43.9-59.7 mbsf)}

Lithostratigraphic Subunit IB is composed of contorted and faulted greenish gray and reddish brown clay and centimeter- to decimeter-thick beds and laminae of black clay (Fig. F4). This lithology is similar to the lithology of Subunit IA but is deformed. Characteristics of faults were measured on the split core face and are summarized in Table T5. Generally, these are reverse faults with dips of $\sim 30^{\circ}$. The top of this subunit corresponds closely to seismic Reflector S10 (Fig. F2). The seismic character of this subunit is chaotic with low-amplitude reflections and is distinct from the otherwise laterally continuous seismic reflections above and below this subunit (Fig. F4 in the "Site U1322" chapter). This is discussed further in "Core-seismic intergration."

\section{Subunit IC (59.7-107.0 mbsf)}

Lithostratigraphic Subunit IC is composed of couplets of greenish gray and brownish gray laminae and beds up to $2-3 \mathrm{~cm}$ thick (Fig. F5). A minor component of silt occurs throughout this subunit as thin, discontinuous lenses and burrow fills a millimeter in diameter. Burrow fills are dominated by quartz grains with minor amounts of carbonate fragments and sponge spicules, as determined by smear slide analyses (Fig. F14). 


\section{Subunit ID (107.0-151.0 mbsf)}

Lithostratigraphic Subunit ID is composed of faulted and contorted reddish brown and greenish gray clay couplets (Fig. F6). Bed dips are typically $\sim 20^{\circ}$, and faults are mostly normal faults with small offset. Resistivity-at-the-bit (RAB) images of the formation in this subunit reveal dipping beds $\left(5^{\circ}-55^{\circ}\right)$ throughout the interval (see "Downhole measurements"). The base of this subunit occurs just above the prominent seismic Reflector S30.

\section{Subunit IE (151.0-264.8 mbsf)}

Lithostratigraphic Subunit IE is a thick interval composed of 1-2 cm thick couplets of dark gray to light gray clay laminae and thin beds (Fig. F7). At the base of each couplet, dark gray clay has a slightly higher content of silt and organic matter than light gray clay; the couplets are normally graded. Black clay layers are commonly irregular and mottled rather than forming continuous laminae (Fig. F7). This subunit contains scattered white silt specks (burrow fills), burrows highlighted by black iron sulfides, and rare silt laminae. An interval enriched in foraminifers and nannofossils occurs between 165.0 and 167.2 mbsf, which corresponds closely with seismic Reflector S30.

\section{Subunit IF (264.8-286.1 mbsf)}

Lithostratigraphic Subunit IF is composed of faulted and contorted couplets of green and brownish green clay. Beds are steeply dipping (up to $70^{\circ}$ ) with smalloffset faults and folding (Fig. F8). RAB images confirm the occurrence of deformed sediments in this subunit (see "Downhole measurements").

\section{Subunit IG (286.1-364.7 mbsf)}

Lithostratigraphic Subunit IG is composed of greenish gray, reddish brown, and black mottled clay (Fig. F9) commonly arranged in couplets $2-7 \mathrm{~cm}$ thick with black clay grading to brownish gray and greenish gray clay. The black clay has a slightly higher component of silt than the greenish gray and brownish gray clay, and each couplet is normally graded. Black color is possibly caused by precipitation of iron sulfides and red/brown color by precipitation of iron oxides. A single bed of massive gray medium sand occurs from 305.7 to $306.8 \mathrm{mbsf}$, but otherwise this subunit is dominated by clay (Fig. F9).

\section{Unit II}

Interval: Sections 308-U1324B-46X-2, $75 \mathrm{~cm}$, through $74 \mathrm{X}-7,40 \mathrm{~cm}$

Depth: 364.7-600.8 mbsf

Age: late Pleistocene
Lithology: silt and very fine sand

Lithostratigraphic Unit II extends from 364.7 to $600.8 \mathrm{mbsf}$ and includes four subunits (IIA-IID). The top of this unit is defined at the top of a normally graded thin bed of silt at 364.7 mbsf that marks a fundamental change in lithology in Hole U1324B. The unit predominantly includes interbedded silt and very fine sand with beds and laminae of mud and clay. Subunit divisions were distinguished by distinct intervals of contorted sediment.

\section{Subunit IIA (364.7-445.5 mbsf)}

Lithostratigraphic Subunit IIA is composed of bioturbated and mottled laminae and beds of greenish gray and reddish brown mud interbedded with normally graded reddish brown silt and very fine sand (Fig. F10). Laminae and bed thicknesses range from 1 to $45 \mathrm{~cm}$. X-ray diffraction (XRD) analyses of green and red clay show that the samples are dominated by quartz and contain calcite, dolomite, feldspars, mica (illite), kaolinite, and chlorite; the X-ray diffractograms are similar in the two types of clay (Fig. F15). Carbon analyses show total carbon content of 2.4 and $2.5 \mathrm{wt} \%$ for the red and green clay, respectively. Thus, the variations from reddish brown, greenish gray, and blackish gray appear to be related primarily to precipitation of iron oxides or sulfides, depending on the redox conditions within the sediment.

\section{Subunit IIB (445.5-481.9 mbsf)}

Lithostratigraphic Subunit IIB is composed of contorted interbeds of brown and gray silty sand and contorted beds of green and red clay (Fig. F11). Rare burrows filled with sandy silt occur throughout this subunit. Deformed beds are well expressed in Cores 308-U1324B-57X through 59X.

\section{Subunit IIC (481.9-578.9 mbsf)}

Lithostratigraphic Subunit IIC is composed of interbedded greenish gray and reddish brown mud with thin beds and light gray silt laminae (Fig. F12). Silt beds are normally graded with sharp bases and gradational tops to mud. A few silt beds have scoured bases. Very fine lower sand occurs in thin, discontinuous light gray and tan laminae. Figure F12E shows a photomicrograph of silt from this subunit that is dominated by quartz with abundant mica grains. Drilling mud was observed to penetrate silt/mud interbeds, and it lined the outside margins of the core sections.

\section{Subunit IID (578.9-600.8 mbsf)}

Lithostratigraphic Subunit IID is composed of contorted interbeds of silty sand with greenish gray mud (Fig. F13). Folds and tilted beds are observed in cores 
but XCB disturbance and biscuiting mask the original structures (Fig. F13). RAB images of this subunit reveal a striking three-dimensional (3-D) view of a fold with the fold axis trending north-south (see "Downhole measurements").

\section{Interpretation of lithostratigraphy}

Lithostratigraphic Unit I (0-364.7 mbsf) is interpreted to record a succession of rapidly deposited levee turbidite clay and mud with discrete intervals of MTDs. Lithostratigraphic Subunit IA is interpreted to be hemipelagic drape and very distal turbidites from the Old and Young Timbalier Canyon channellevee systems to the west (Winker and Shipp, 2002). The subtly graded couplets of light and dark gray clay in each subunit throughout lithostratigraphic Unit I may record fine-grained turbidity current overspill on the east levee of the Southwest Pass Canyon. Sedimentation rates for lithostratigraphic Unit I are estimated to be $\sim 0.4-0.6 \mathrm{~cm} / \mathrm{y}$ (see "Biostratigraphy"). Considering that the average thickness of clay laminae couplets is $\sim 2 \mathrm{~cm}$, the overspill events recorded at Site U1324 would occur, on average, every 4 y. Similar color bands and laminations in mud and clay sediment from the Amazon Fan levees were interpreted to record turbidity current overspill events occurring every 1-3 y (Piper and Deptuck, 1997; Pirmez and Isram, 2003). Lithostratigraphic Subunits IB, ID, and IF are only different compared to the other subunits within lithostratigraphic Unit I by being composed of tilted, contorted, and faulted beds. This suggests that these intervals have been remobilized downslope and they are thus interpreted as MTDs. We infer that the relatively mild deformation observed in these subunits indicates that they have remained relatively intact during transport and probably have not moved significant distances from their original deposition location.

The base of lithostratigraphic Unit I and top of lithostratigraphic Unit II at 364.7 mbsf marks a distinct lithologic change separating mud and clay above from interbedded sand, silt, and mud below. This boundary ties closely to seismic Reflector S40-1324, which also marks a fundamental change in seismic facies (Fig. F2). In lithostratigraphic Unit I, the seismic facies is predominantly characterized by intervals of continuous subparallel reflections and by transparent intervals. The seismic facies of lithostratigraphic Unit II is very chaotic and discontinuous. This major boundary also marks distinct character changes in the gamma ray and resistivity logs (Fig. F2; see "Downhole measurements"). Above this boundary, both logs do not show major variations. Below this boundary, resistivity varies frequently and ties well with the thin beds and laminae of silt and sand observed in lithostratigraphic Unit II. Gamma radiation indicates the presence of more silt and sand below this boundary as well.

A marked change in the evolution of the Southwest Pass Canyon is interpreted to be recorded at the lithostratigraphic Unit I/II boundary. Before a single confining channel was established in the Southwest Pass Canyon system, there were probably numerous low-relief channels that were unable to completely confine the turbidity currents, leading to abundant overspill of sand and silt. Thus, the sedimentary succession of lithostratigraphic Unit II is dominated by thin beds of silt and sand interbedded with mud representing overbank deposits. The sands and silts tie to discontinuous reflectors and lenses in seismic data and are not regionally extensive. Lithostratigraphic Subunits IIB and IID are interpreted to be MTDs consistent with a dynamic environment with high sedimentation rate and extensive overspill. It is possible that the triggering mechanisms for the MTDs in lithostratigraphic Unit I and those in lithostratigraphic II are different. The MTDs of lithostratigraphic Unit I were potentially related to low effective stresses developed in the thick levee assemblage above the Blue Unit. The MTDs of lithostratigraphic Unit II were probably associated with the dynamic depositional environment of the young Southwest Pass Canyon channel-levee system.

\section{Core-seismic integration}

Comparison of 3-D seismic survey Line 150 (Fig. F4 in the "Site U1322" chapter) with Site U1324 lithostratigraphy suggests a strong correlation between seismic facies and lithostratigraphic units. Lithostratigraphic Unit I extends from the seafloor to just below seismic Reflector S40-1324 at 364.7 mbsf and is characterized overall by intervals of laterally continuous, high-amplitude reflectors and intervals of acoustically transparent and/or chaotic and discontinuous reflectors.

Lithostratigraphic Subunits IB, ID, and IF are characterized by faulted and contorted bedding and tie closely to the transparent/chaotic seismic facies (Fig. F2; see also Fig. F4 in the "Site U1322" chapter). Such acoustically transparent/chaotic intervals are interpreted to be MTDs that were not transported very far but rather slumped and faulted during a short transport. The strong regional seismic Reflector S30 at the base of a thick transparent/chaotic interval ties to just below the base of lithostratigraphic Subunit ID. It is interpreted that this subunit represents a regional-scale MTD (Fig. F4 in the "Site U1322" chapter). This MTD can be correlated to Sites U1323 and U1322 in the seismic section. 
Lithostratigraphic Unit II extends from the base of lithostratigraphic Unit I just below seismic Reflector S40-1324 to the TD at $608 \mathrm{mbsf}$ and is characterized by intervals of high-amplitude chaotic facies and high-amplitude continuous reflections. Seismic Reflectors S50-1324 and S60-1324 occur within this unit.

Lithostratigraphic Subunits IIB and IID are characterized by faulted and contorted sediment and tie closely with the intervals of high-amplitude chaotic zones (Fig. F2). These subunits are interpreted to be MTDs but are not seismically transparent like the MTDs of lithostratigraphic Unit I. The high-amplitude signature may be related to the abundance of thin bedded silt, sand, and mud observed throughout lithostratigraphic Unit II. These subunits are not regionally extensive and do not correlate to Sites U1323 or U1322.

Lithostratigraphic Subunits IIA and IIC tie closely to high-amplitude continuous reflectors between seismic Reflectors S40-1324 and S60-1324 (Fig. F2). These subunits are not characterized by faulted and contorted sediment and contain interbedded silt, sand, and mud and thin laterally to the east and are truncated by MTDs (Fig. F4 in the "Site U1322" chapter).

\section{Summary interpretation}

Site U1324B recovered a thick sedimentary succession overlying the Blue Unit and records the evolution of the eastern levee of the Southwest Pass Canyon channel-levee system. Lithostratigraphic Unit I is composed of clay, mud, and three MTDs. Lithostratigraphic Unit II is composed of interbedded silt, sand, and mud and two MTDs. The boundary between these units reflects a fundamental change in the development of the Southwest Pass Canyon channel-levee system. Below this boundary, a transitional period characterized by relatively unconfined deposition of sand, silt, and mud reflects a young developing channel-levee system. Above this boundary, the Southwest Pass Canyon channel-levee system was firmly established west of Site U1324 and was effective in confining sands and silts to a main channel corridor. Overspill of mud and clay developed the thick levee assemblage recorded in lithostratigraphic Unit I. Core-seismic integration suggests that acoustically transparent intervals are regional MTDs composed of faulted and contorted mud and clay. However, close examination reveals that these MTDs contain levee clay and mud that are only mildly deformed and tilted and were not transported very far from their in situ position.

\section{Biostratigraphy}

Calcareous nannofossils and foraminifers were studied in all core catcher samples from Holes U1324B and U1324C plus several samples from Cores 308U1324B-9H, 14H, 19H, and 27H. Rare to common calcareous nannofossils and foraminifers with good to moderate preservation occur in samples above 350 mbsf, with reduced abundance toward the bottom of the holes.

We identified nannofossil Zone QAZ1 Emiliania huxleyi Acme with Subzones A and B, as well as planktonic foraminifer Zones $\mathrm{Z}$ and $\mathrm{Y}$ (including Subzones Y1-Y5) (Fig. F16). Nannofossil and planktonic foraminifer data indicate that, similar to Site U1322, the sediment sequence recovered at Site U1324 was deposited during the last $60 \mathrm{k} . \mathrm{y}$. However, the average sedimentation rate of $\sim 10 \mathrm{~m} / \mathrm{k} . \mathrm{y}$. , is 2.5 times higher than that for Site U1322. Benthic foraminifers are dominated by infaunal species that prefer low-oxygen "stress" environments, which is expected for such rapid sedimentation rates.

\section{Calcareous nannofossils}

Calcareous nannofossils were encountered in all samples from Holes U1324B and U1324C (Figs. F17, F18, F19, F20). Samples 308-U1324B-7H-2, $30 \mathrm{~cm}$, and $27 \mathrm{H}-1,13-18 \mathrm{~cm}$, contain abundant nannofossils. Preservation ranges from good to moderate throughout the holes. Coarse-grained samples typically contain poorly preserved nannofossils with low to barren overall abundance. Nannofossils in samples below 238.65 mbsf in Hole U1324B are less abundant, but it is unclear why. Nannoplankton assemblages contain rare to common in situ and reworked species. E. huxleyi is the dominant in situ species. Other species, Braarudosphaera bigelowii, Calcidiscus leptoporus, Coccolithus pelagicus, Discosphaera tubifera, Gephyrocapsa aperta, Gephyrocapsa caribbeanica, Gephyrocapsa ericsonii, Gephyrocapsa oceanica, Gephyrocapsa sinuosa, Helicosphaera carteri, Helicosphaera wallichii, Pontosphaera multipora, Reticulofenestra productella, Rhabdosphaera clavigera, Rhabdosphaera procera, Scapholithus fossilis, Syracosphaera histrica, Thoracosphaera spp., and Umbilicosphaera sibogae were sporadically encountered. G. oceanica is always more abundant than G. caribbeanica, although both rarely constitute $10 \%$ of the total abundance. The majority of reworked species are Cretaceous in age (>99\%) and occur throughout the section (Figs. F17, F19, F20). Samples 308-U1324B-1H-CC, 19-24 cm, through 7H-CC, $29-34 \mathrm{~cm}$, contain high numbers of other reworked Mesozoic species.

Generally, species abundances vary significantly from sample to sample. This could be due to cyclic 
fluctuations in sediment input from turbidity currents in Ursa Basin. This is supported by the relationship that we observed: the more abundant the in situ assemblages, the less abundant the reworked Mesozoic assemblages are, and vice versa (Fig. F17). We found that in situ nannofossils are better preserved in hemipelagic deposits, whereas deposits with higher terrigenous content are richer in reworked Mesozoic assemblages. Lower abundances of nannofossils toward the bottom of the holes point to the possibility that sedimentation rates (Subzone B) were very high in comparison to the upper section (Subzone A).

Based on the nannofossil stratigraphic subdivision of Hine and Weaver (1998), we recognized QAZ1 E. huxleyi Acme Zone in the sediment sequence recovered at Site U1324. The zone can be subdivided into Subzones A and B, which correlates well to Holes U1324B and U1324C.

\section{QAZ1 E. huxleyi Acme Zone}

We identified this zone in Samples 308-U1324B-1HCC, 7-12 cm, through 74X-CC, 36-43 cm, based on the high abundance of $E$. huxleyi (70\% or more). According to Berggren et al. (1995), the first occurrence datum of E. huxleyi acme is at $90 \mathrm{ka}$. In situ species have sporadic distribution throughout the holes. Reworked Mesozoic assemblages form $>50 \%$ of the total nannofossil abundance in most samples from Site U1324. They typically have higher values in MTDs (Fig. F18), lithostratigraphic Subunits IB, ID, IF, IIB, and IID (see "Lithostratigraphy").

\section{Subzone A}

We distinguished Subzone A in samples above 352.74 mbsf of Holes U1324B (308-U1324B-1H-CC through 43H-CC) and U1324C (308-U1324C-1H-CC through $6 \mathrm{H}-\mathrm{CC})$. This interval is characterized by higher abundances of both in situ and reworked nannofossils relative to the lower section. The in situ species E. huxleyi has a cyclic distribution throughout Subzone A. Subzone A correlates with lithostratigraphic Unit I between seismic Reflectors S10 and S40-1324.

\section{Subzone B}

Subzone B, with low abundances of in situ assemblages, was identified in samples below $357.79 \mathrm{mbsf}$ in Holes U1324B (Samples 308-U1324B-44H-CC through 74X-CC) and U1324C (Samples 308U1324C-7H-CC through 8H-CC). Reworked Mesozoic assemblages are less abundant relative to Subzone A. Two peaks of reworked Mesozoic assemblages are associated with MTDs. Subzone B correlates with lithostratigraphic Unit II between seismic Reflectors S50-1324 and S60-1324.

\section{Planktonic foraminifers}

Planktonic foraminifers are frequent to abundant in samples from core catchers and selected cores above Cores 308-U1324B-29H and 308-U1324C-4H (above $\sim 250$ mbsf). Further downhole, planktonic foraminifer abundances are rare to trace and even barren in Samples 308-U1324B-48H-CC, 52X-CC, and 71X-CC through $74 \mathrm{X}$-CC. In most samples, the preservation was good to excellent overall, and only a few specimens exhibit abraded features indicative of reworking. Semiquantitative data for planktonic foraminifers in Hole U1324B are presented in Table T6.

As at other Expedition 308 sites, the planktonic foraminifer assemblage found in samples from Site U1324 is dominated by typical subtropical to temperate taxa. The most abundant species is Globigerinoides ruber (both the pink and white forms), averaging $50 \%$ or more. Species found frequently include Globigerinoides sacculifer, Globigerinoides conglobatus, Neogloboquadrina dutertrei, Globorotalia truncatulinoides, Globorotalia inflata (older than $10 \mathrm{ka}$ ), Globorotalia crassaformis, Globigerinella siphonifera, Orbulina universa, Globigerina falconensis, and Globigerina quinqueloba. Globorotalia menardii and Globorotalia tumida are found only in Sample 308-U1324B-1HCC, 19-24 cm, whereas Pulleniatina obliquiloculata not only occurs in the same sample, but a single specimen of this species was also observed in three other widely separated samples from the lower part of the core: Samples 308-U1324B-40H-CC, 31-36 $\mathrm{cm}, 56 \mathrm{X}-\mathrm{CC}, 36-41 \mathrm{~cm}$, and 61X-CC, 37-42 cm (Fig. F21). Other species, including Globigerina bulloides, Globigerinita glutinata, Hastigerina pelagica, and Globigerinella calida, are very rare and may occur sporadically.

Planktonic foraminifer assemblage Zones $\mathrm{Z}$ and $\mathrm{Y}$ (including Subzones Y1, Y2, Y3, and Y3-Y6?) (Kennett and Huddlestun, 1972) were identified, suggesting that the sediment recovered at Site U1324 was deposited mainly during the last 60 k.y., during marine isotope Stages (MIS) 1-3 (4?) (Fig. F21). The bottom of the core cannot be dated because of the absence of planktonic foraminifers. The last occurrence datum of $G$. flexuosa at $68 \mathrm{ka}$ and the temporary last occurrence of consistent $P$. obliquiloculata at $\sim 65 \mathrm{ka}$ (Kennett and Huddlestun, 1972) were not found at Site U1324. Therefore, the sediments recovered at Site U1324 are likely younger than $65 \mathrm{ka}$. Abundant planktonic foraminifers found in Samples 308U1324B-10H-CC, 29-34 cm, and 19H-3, 53-58 cm, may have been influenced by warm interstadial events 2.1 and 3.1, respectively. 


\section{Zone Z}

This zone is represented only by Sample 308U1324B-1H-CC, 19-24 cm (Fig. F21). The planktonic foraminifer assemblage is characterized by abundant warm-water species including G. menardii, G. sacculifer, G. crassaformis, P. obliquiloculata, and G. ruber. The absence of the cool-water species $G$. inflata indicates an age younger than $10.5 \mathrm{ka}$ (Kennett and Huddlestun, 1972).

\section{Zone $\mathrm{Y}$}

From Cores 308-U1324B-2H through 74X and 308$\mathrm{U} 1324 \mathrm{C}-1 \mathrm{H}$ through $8 \mathrm{H}$, planktonic foraminifer assemblages are dominated by $G$. ruber and $G$. inflata, and the absence of warm-water species $G$. menardii (Zones X and Z), G. flexuosa (lower Subzone Y6 and below), and $P$. obliquiloculata (middle Subzone Y6 and below), collectively suggests that the sediment section spans Subzones Y1-Y6(?). Samples from Core $308-\mathrm{U} 1324 \mathrm{~B}-43 \mathrm{H}$ with very rare planktonic foraminifers are grouped together as representing an interval from the lower part of Subzone Y5 to probably Y6 (Fig. F21), approximately equating to lithostratigraphic Unit II (see "Lithostratigraphy"). Because of the semiquantitative nature of our work on board, the subdivision of Zone $\mathrm{Y}$ requires further studies to be confirmed or modified.

\section{Subzone Y1}

Samples 308-U1324B-2H-CC, 15-20 cm, and 3H-CC, $19-24 \mathrm{~cm}$, having abundant $G$. ruber and frequent $G$. crassaformis and G. siphonifera but reduced G. inflata, are assigned to Subzone Y1. According to Kennett and Huddlestun (1972), Subzone Y1 represents a short interval at the MIS $1 / 2$ transition between $\sim 10.5$ and $16 \mathrm{ka}$.

\section{Subzone Y2}

Although G. ruber remains frequent, the cool-water species $G$. inflata becomes frequent to common, especially in the lower part of the Subzone Y2, in Cores $308-U 1324 \mathrm{~B}-13 \mathrm{H}$ through $16 \mathrm{H}$. G. crassaformis and G. siphonifera are also consistently present and may become frequent only occasionally. Between Cores 308-U1324B-4H and 9H, G. truncatulinoides is very rare or absent. An increase in the number of planktonic foraminifers, especially G. crassaformis, G. falconensis, and G. conglobatus, in Sample 308-U1324B$10 \mathrm{H}-\mathrm{CC}, 29-34 \mathrm{~cm}$, may signal the influence of warmer climatic conditions such as those during MIS 2.21. Subzone Y2 represents deposition during MIS 2 (Kennett and Huddlestun, 1972) and spans the last 16-24 k.y. based on the timescale of Bassinot et al. (1994).

\section{Subzone Y3}

Cores 308-U1324B-17H through $29 \mathrm{H}$ are assigned to Subzone Y3 based on the consistent occurrence of many planktonic foraminifers, particularly G. sacculifer and G. inflata without G. menardii and its allied species. G. conglobatus, a species preferring warmer water conditions, occurs in three intervals: from Sample 308-U1324B-19H-2, 52-57 cm, through 19H$3,53-58 \mathrm{~cm}$; $22 \mathrm{H}-\mathrm{CC}, 29-34 \mathrm{~cm}$, through $25 \mathrm{H}-\mathrm{CC}$, $36-41 \mathrm{~cm}$; and $28 \mathrm{H}-\mathrm{CC}, 43-48 \mathrm{~cm}$, through $29 \mathrm{H}-\mathrm{CC}$, $50-55 \mathrm{~cm}$. Dominated by subtropical species, the planktonic foraminifer assemblage from Sample 308U1324B-25H-CC, 36-41 cm, shows all the characteristics of warm conditions within Subzone Y3 (Fig. F21; Table T7). Subzone Y3 represents deposition during the later part of MIS 3 (Kennett and Huddlestun, 1972) and has an age of $24-42$ ka based on the timescale of Bassinot et al. (1994).

\section{Subzone $Y 4$}

Subzone Y4, characterized by frequent $G$. inflata and G. falconensis, spans Samples 308-U1324B-30H-CC, $19-24 \mathrm{~cm}$, through $38 \mathrm{H}-\mathrm{CC}, 40-45 \mathrm{~cm}$. G. sacculifer and G. crassaformis are rare, and G. conglobatus is absent. The upper part of Subzone Y4 corresponds to lithostratigraphic Subunit ID (see "Lithostratigraphy"). Subzone Y4 represents deposition in the middle part of MIS 3 (Kennett and Huddlestun, 1972), which lasted from $\sim 42$ to $48 \mathrm{ka}$ on the timescale of Bassinot et al. (1994).

\section{Subzone Y5}

Samples 308-U1324B-39H-CC, 40-45 cm, through $42 \mathrm{H}-\mathrm{CC}, 31-36 \mathrm{~cm}$, with frequent $G$. sacculifer and $G$. crassaformis, can be assigned to Subzone Y5. Other species including G. ruber, G. sacculifer, G. siphonifera, $G$. inflata, and N. dutertrei are frequent or common. However, rare G. conglobatus occurs only in Sample 308-U1324B-39H-CC, 40-45 cm, whereas a single specimen of $P$. obliquiloculata is found in Sample $40 \mathrm{H}-\mathrm{CC}, 31-36 \mathrm{~cm}$. Overall, the planktonic foraminifer assemblage from Subzone Y5 supports interpretation of a gradually warming trend across the MIS 3/4 boundary (Kennett and Huddlestun, 1972) at 48-57 ka (Bassinot et al., 1994).

\section{Subzone Y5-Y6?}

Planktonic foraminifers are very rare or barren in samples from Cores 308-U1324B-43H through 74X in lithostratigraphic Unit II, characterized by interbedded thin silt and mud layers and MTDs (see "Lithostratigraphy"). The interval is collectively assigned to Subzone Y5-Y6? pending further studies. The absence of G. menardii (Zone X, $85 \mathrm{ka}$ and older) and G. flexuosa (lower Subzone Y6, $68 \mathrm{ka}$ and older) 
suggests that the sediment section must be younger than $68 \mathrm{ka}$. The temporary last occurrence of consistent $P$. obliquiloculata was $\sim 65$ k.y. ago, in Subzone Y6 (Kennett and Huddlestun, 1972; Mallarino et al., in press). Solid evidence of this event was not found at Site U1324, but sporadic $P$. obliquiloculata occurs in Samples 308-U1324B-56X-CC, 36-41 cm, and 61XCC, $37-42 \mathrm{~cm}$ (as well as $40 \mathrm{H}-\mathrm{CC}, 31-36 \mathrm{~cm}$, mentioned above) and may bear an age close to $65 \mathrm{ka}$, although we cannot rule out that these single specimens were reworked.

\section{Benthic foraminifers}

Benthic foraminifers are rare to common in core catcher samples from Cores 308-U1324B-1H through $43 \mathrm{H}$ and $308-\mathrm{U} 1324 \mathrm{C}-1 \mathrm{H}$ through $6 \mathrm{H}$, above $\sim 350$ mbsf, but are very rare or barren further downhole (Fig. F22). Preservation in most samples varies from good to very good except for displaced or reworked specimens. The assemblages include mainly calcareous taxa and only few species and specimens of porcelaneous taxa. The benthic foraminifers generally represent well-known neritic to "deepwater" taxa that prefer oxygen-poor, nutrient-rich environments. The Bolivina-Bulimina assemblage, which was described at Sites U1319 and U1320, is also found at Site U1324 (above 330 mbsf). A Valvulineria assemblage characterized by common occurrences of Valvulineria bradyana is newly identified in Sample 308U1324B-40H-CC, 31-36 cm. Below 350 mbsf, no assemblages can be recognized because few or no benthic foraminifers are present. Rare Ammonia beccarri, representing reworked inner neritic species, only occurs in Samples 308-U1324B-17H-CC, 33-38 $\mathrm{cm}$, and $18 \mathrm{H}-\mathrm{CC}, 31-36 \mathrm{~cm}$. Semiquantitative data of benthic foraminifers from Hole U1324B are listed in Table T6.

\section{Bolivina-Bulimina assemblage}

The Bolivina-Bulimina assemblage was recovered from Cores 308-U1324B-1H through $39 \mathrm{H}$ and 308U1324C-1H through $6 \mathrm{H}$. As already described from Sites U1319 and U1320, this assemblage is characterized by abundant small thin-shelled species including Bolivina spissa, Bolivina spp., Bulimina aculeata, Uvigerina spp., Fursenkoina bradyi, Stainforthia complanata, and Chilostomella ovoidea. Other species that also occur are Globobulimina affinis, Quinqueloculina spp., Gyroidina spp., Cibicidoides spp., Sphaeroidina bulloides, and Oridorsalis tenera. This infauna-dominated assemblage indicates upper slope to lower bathyal depths greater than $400 \mathrm{~m}$ with low oxygen content. Fluctuations in the relative abundance of these species, especially above 260 mbsf (Fig. F22), may reflect cyclic changes in sediment load and bottom water circulation.

\section{Valvulineria assemblage}

We recognized the Valvulineria assemblage in Sample 308-U1324B-40H-CC, 31-36 cm. Although species of the Bolivina-Bulimina assemblage remain frequent, the common occurrence of Valvulineria bradyana in Sample 308-U1324B-40H-CC, 31-36 cm, warrants a separation. Like many infaunal Bolivina and Bulimina species, the epifaunal Valvulineria spp. are also stress markers (van Hinsbergen et al., 2005), but the latter's epifaunal living mode suggests that the stress conditions were probably not caused by fast sediment loading and low oxygen content, as indicated by infaunal species, but were more likely a result of circulation change in the later part of Subzone Y5, across the MIS 3/4 boundary, as described above.

\section{Age model and sedimentation rates}

The age models developed during the expedition are preliminary. Biostratigraphic dating of Pleistocene sediments is difficult, and we had to rely on several assumptions to constrain age models and sedimentation rates. In the case of Site U1324, we took into consideration planktonic foraminifer biostratigraphic data and some magnetostratigraphic tie points (Table T8; Fig. F23). The magnetostratigraphic tie points were derived by matching the rock magnetic record with a global $\delta^{18} \mathrm{O}$ curve (see "Paleomagnetism" in the "Methods" chapter), and they are thus very interpretive. The biostratigraphic age constraints are mainly derived from the modified ages for the boundaries between planktonic foraminifer subzones according to the timescale of Bassinot et al. (1994) (see "Biostratigraphy" in the "Methods" chapter). The estimated sedimentation rates (Fig. F23) are $0.86 \mathrm{~m} / \mathrm{k} . \mathrm{y}$. between the seafloor and 8.65 mbsf (last occurrence [LO] of G. inflata), 10.0 $\mathrm{m} / \mathrm{k}$.y. between 8.65 and $163.0 \mathrm{mbsf}$ (Subzone Y2/Y3 boundary), $5.5 \mathrm{~m} / \mathrm{k} . \mathrm{y}$. between 163.0 and $252.0 \mathrm{mbsf}$ (Subzone Y3/Y4 boundary), and $12.0 \mathrm{~m} / \mathrm{k} . \mathrm{y}$. between 252.0 and 323.0 mbsf (Subzone Y4/Y5 boundary). The interval between 163.0 and 252.0 mbsf corresponds to lithostratigraphic Unit I, a unit with few MTDs. This can explain the comparatively low sedimentation rates for this interval $(5.5 \mathrm{~m} / \mathrm{k} . \mathrm{y}$.). Below 323.0 mbsf, no biostratigraphic datum was recovered. However, considering that we did not retrieve P. obliquiloculata specimens, we infer that the oldest sediment recovered is younger than the LO of this species (Subzone Y6, $65 \mathrm{ka}$ for the LO of consistent P. obliquiloculata [Kennett and Huddlestun, 1972; Mallarino et al., in press]). Thus, assuming that the oldest sediment recovered is $65 \mathrm{ka}$, we estimate a sedimentation rate $>25 \mathrm{~m} / \mathrm{k} . \mathrm{y}$., but this could be even greater (up to $50 \mathrm{~m} / \mathrm{k}$.y.) if we assumed that the sediment was deposited starting in Subzone Y6. We 
note that magnetic tie points 3 (10 mbsf; $26 \mathrm{ka}$ ) and 4 (470 mbsf; $52 \mathrm{ka}$ ) are in relative good agreement with the proposed age model (Table T8; Fig. F23). More rigorous postcruise work is needed to confirm this interpretation.

\section{Paleomagnetism}

Archive halves were measured in the pass-through cryogenic magnetometer to a peak alternating-field (AF) demagnetization of $20 \mathrm{mT}$ (see Table T9). APC coring was used from Cores $308-\mathrm{U} 1324 \mathrm{~B}-1 \mathrm{H}$ to $50 \mathrm{H}$; Cores $4 \mathrm{H}$ to $50 \mathrm{H}$ were oriented using the Tensor tool. The XCB drilling system was deployed (see "Summary of operations") beginning with Core 308U1324B-51X. The special geotechnical cutting shoe from Fugro Inc. was deployed in some cores (Table T9), which resulted in a considerable magnetic overprint (see discussion below).

\section{Paleomagnetic intervals}

Hole U1324B was divided into five intervals based on paleomagnetic measurements (Fig. F24).

\section{Interval 1 (0-260 mbsf)}

Paleomagnetic Interval 1 includes lithostratigraphic Subunits IA-IE. Natural remanent magnetization after $20 \mathrm{mT}$ AF demagnetization $\left(\mathrm{NRM}_{20 \mathrm{mT}}\right)$ in this interval averages $0.006 \mathrm{~mA} / \mathrm{m}$ (Fig. F24A). This interval can be separated into two paleomagnetic subintervals (1A and 1B) corresponding to lithostratigraphic Subunits IA-IC and ID-IE, respectively. In paleomagnetic Subinterval 1A (0-110 mbsf) $\mathrm{NRM}_{20 \mathrm{~m}}$ has a lower mean value $(0.004 \mathrm{~mA} / \mathrm{m})$ than in Subinterval 1B $(\sim 0.008 \mathrm{~mA} / \mathrm{m})$.

Declination in paleomagnetic Interval 1 is scattered between $0^{\circ}$ and $360^{\circ}$. The average declination in this interval changes from $90^{\circ}$ at 0 mbsf to $270^{\circ}$ at 260 mbsf (Fig. F24B). In general, the declination signal is very noisy and therefore unreliable. Inclination in paleomagnetic Interval 1 shows an average normal polarity of $20^{\circ}$ (Fig. F24C). The inclination signal exhibits the same level of noise as the declination data and is therefore not considered reliable in this interval. Two trends can be observed; inclination directions decrease from $60^{\circ}$ to $-30^{\circ}$ between 0 and 180 mbsf and revert to $\sim 30^{\circ}$ at 180 to 260 mbsf.

\section{Interval 2 (260-365 mbsf)}

Paleomagnetic Interval 2 spans lithostratigraphic Subunits IF-IG (260-365 mbsf) and has $\mathrm{NRM}_{20 \mathrm{mT}}$ intensity values $\sim 2.5$ times greater than those in Interval $1(0.015 \mathrm{~mA} / \mathrm{m})$ (Fig. F24A). The average declination of $330^{\circ}$ is comparatively stable in Interval 2 (Fig.
F24B). The same stable trend is observed in inclination, showing directions with an average value of $30^{\circ}$ (Fig. F24C).

\section{Interval 3 (365-440 mbsf)}

$\mathrm{NRM}_{20 \mathrm{~m}}$ values in paleomagnetic Interval 3 (corresponding to lithostratigraphic Subunit IIA) average $0.015 \mathrm{~mA} / \mathrm{m}$ and are comparable to those of Interval 2 (Fig. F24A). However, the noise level of $\mathrm{NRM}_{20 \mathrm{mt}}$ in Interval 3 is higher than in Interval 2. This may be due to changes in lithology (see "Lithostratigraphy") from mud and clay-rich sediments in lithostratigraphic Unit I to sand-silt interbedded facies in lithostratigraphic Unit II. Declination across Interval 2 to Interval 3 shows a sudden change from $330^{\circ}$ to $50^{\circ}$ (Fig. F24B), which clearly coincides with the change from APC to XCB coring. The Tensor tool is not deployed with $\mathrm{XCB}$ and hence declination data below Core 308-U1324B-51X could not be corrected. The inclination signal shows a relatively stable normal polarity of $40^{\circ}$ throughout Interval 3 (Fig. F24C).

\section{Interval 4 (440-490 mbsf)}

Paleomagnetic Interval 4 includes the highest variations of $\mathrm{NRM}_{20 \mathrm{mT}}$ in Hole U1324B. The upper part of Interval 4 (440-460 mbsf) reaches a maximum of $0.03 \mathrm{~mA} / \mathrm{m}$, which is 10 times that in the lower part of the interval (460-490 mbsf; $\mathrm{NRM}_{20 \mathrm{mT}}=\sim 0.003 \mathrm{~mA}$ / $\mathrm{m})$. This feature can be correlated with the sandy MTD of lithostratigraphic Subunit IIB. Declination in Interval 4 has a relatively stable average direction of $\sim 50^{\circ}$ (Fig. F24B). Inclination values have stable normal polarities of $65^{\circ}$ throughout Interval 4 (Fig. F24C).

\section{Interval 5 (490-608 mbsf)}

Paleomagnetic Interval 5 has an average $\mathrm{NRM}_{20 \mathrm{mT}}$ intensity of $0.01 \mathrm{~mA} / \mathrm{m}$ (Fig. F24A). This interval corresponds to lithostratigraphic Subunits IIC and IID. The noise level in the $\mathrm{NRM}_{20 \mathrm{~m}}$ signal is comparable to that in Interval 3. Declination shows relatively stable directions, slightly higher than $50^{\circ}$, and thus is similar to those in Interval 4 (Fig. F24B). Inclination values have stable normal polarities, very similar to those of Interval 4 (Fig. F24).

The Mono Lake Excursion, Lake Mungo Event, and Lachamps Excursion (Clark and Kennett, 1973; Freed and Healy, 1974; Stupavsky and Gravenor, 1984; Flood, Piper, Klaus, et al., 1995; Cisowski and Hall, 1997) were not identified in Hole U1324B.

Observed deviations of inclination and declination data in Hole U1324B often correspond to cores taken with the geotechnical cutting shoe from Fugro Inc. 
(applied during APC coring), which is magnetic (for more details see "Summary of operations") (Table T9; Fig. F24). The shoe caused a considerable magnetic overprint on the recovered sediments, resulting in inclination and declination outliers. Hence, data points from cores recovered using the Fugro cutting shoe are plotted in red in Figure F24 and not included in the data analysis. The drilling overprint in inclination and declination was not removed by the applied peak field of $20 \mathrm{mT}$.

\section{Magnetostratigraphy}

In general, the major trends in the $\mathrm{NRM}_{20 \mathrm{mT}}$ intensity correlate with magnetic volume susceptibility $(\kappa)$, although detailed features are often expressed differently between the two records (Fig. F25). As $\kappa$ is a measure of the bulk sediment, large amounts of paramagnetic clay minerals tend to increase the values, whereas diamagnetic components, such as quartz, dilute the signal of the ferrimagnetic mineral fraction. In comparison, the $\mathrm{NRM}_{20 \mathrm{mT}}$ intensity is carried exclusively by the ferrimagnetic particle fraction of the sediment. For example, the double peak occurring in $\mathrm{NRM}_{20 \mathrm{mT}}$ between 140 and $180 \mathrm{mbsf}$ is dampened in the $\kappa$ signal. Therefore, magnetostratigraphic tie points (MTP1, MTP2, MTP3, and MTP4; for details see "Paleomagnetism" in the "Methods" chapter) are primarily identified using the $\mathrm{NRM}_{20 \mathrm{~m}}$ intensity peaks.

The preliminary and tentative magnetostratigraphic interpretation in Hole U1324B is achieved by correlation of the identified magnetostratigraphic tie points to MIS 1.1-3.3 (Fig. F25A, F25B, F25C, F25D) (Bassinot et al., 1994). Comparison of the $\kappa$ signal of Hole U1324B with the Subtropical South Atlantic susceptibility (SUSAS) stack (von Dobeneck and Schmieder, 1999) (Fig. F25A) also supports our tentative correlation. MTP1 and MTP2 are primarily defined by $\mathrm{NRM}_{20 \mathrm{~m}}$ intensity but are not clearly identified in $\kappa$. MTP3 and MTP4 are identified in $\mathrm{NRM}_{20 \mathrm{mT}}$ intensity as well as $\kappa$.

MTP4 lies within an MTD belonging to lithostratigraphic Subunit IIB. Because this deposit is composed of interbedded sandy and silty layers (see "Lithostratigraphy"), the ferromagnetic fraction in this interval may be concentrated at $\sim 450 \mathrm{mbsf}$ and diluted at $\sim 470$ mbsf. Average values as extreme as those in paleomagnetic Interval 4 are not observed elsewhere in Hole U1324B, nor are they observed in sandy layers or other identified MTDs. Within the possible time frame estimated by biostratigraphic analysis in Hole U1324B (see "Biostratigraphy") magnetostratigraphic tie point MTP4 is thought to coincide with MIS 3.3. This is also consistent with the age of the base of the underlying Blue Unit to MIS 4 (Winker and Shipp, 2002). MTP3 and MTP4 are the only two tie points that are clearly expressed in both magnetic parameters and were therefore included in the age model (see Fig. F22; Table T10).

\section{Geochemistry and microbiology}

\section{Inorganic geochemistry}

\section{Interstitial water geochemistry}

Interstitial water chemical data are listed in Table T11 and shown in Figures F26, F27, F28, and F29. Interstitial water alkalinity shows limited variation between 4.61 and $11.35 \mathrm{mM}$ (Table T11). A downhole increase in alkalinity is observed with local maxima at $43,131,226,411,467,507$, and $584 \mathrm{mbsf}$ (Fig. F26). The $\mathrm{pH}$ of the interstitial water varies between 6.59 and 7.60. The acidic nature of the interstitial water $(\mathrm{pH}<7.0)$ above $200 \mathrm{mbsf}$ in this hole is peculiar and rare for pore water from deep-sea marine sediments. Below 200 mbsf to the bottom of the sampled section, the $\mathrm{pH}$ values are higher and center around $7.3 \pm 0.2$ (Fig. F26).

Salinity varies between 3.3 and 3.8 parts per hundred (pph) (Table T11). At depths above $50 \mathrm{mbsf}$, the salinity is higher and centers at 3.7-3.8 pph. Between 50 and 94 mbsf, salinity decreases from 3.8 to 3.4 pph, and then it remains constant to the bottom of the hole. Interstitial water chlorinity varies from 554 to $570 \mathrm{mM}$, quite similar to the standard seawater value (International Association of Physical Sciences of the Ocean [IAPSO] = 559 $\mathrm{mM}$ ), but a clear decrease in chlorinity is observed at 438 mbsf (Fig. F26).

Dissolved sulfate increases slightly from $30.6 \mathrm{mM}$ at the seafloor to a maximum of $37.3 \mathrm{mM}$ at $\sim 35 \mathrm{mbsf}$ (seismic Reflector S10). Below this depth, $\mathrm{SO}_{4}{ }^{2-}$ decreases to $0 \mathrm{mM}$ at $94 \mathrm{mbsf}$ (Fig. F27), the sulfate/ methane interface (SMI) depth. Interstitial water ammonium concentrations are very high, from 1109 to $6820 \mu \mathrm{M}$, and a general downhole increase is observed within lithostratigraphic Unit I. Variations of ammonium contents occur in lithostratigraphic Unit II, but the values are generally high. Dissolved phosphate concentrations are very low $(<4.0 \mu \mathrm{M})$ with one exception $(9.2 \mu \mathrm{M})$ at $507 \mathrm{mbsf}$ (Table T11). The interstitial water data also show elevated concentrations of dissolved silica $\left(\mathrm{H}_{4} \mathrm{SiO}_{4}\right)$ from 185 to $601 \mathrm{nM}$. Fluctuations similar to those in ammonium are also observed in dissolved silica, and both elements show a slightly antithetical relationship (Fig. F27). Although ammonium and silica contents are higher at greater depths, at shallower depths ammonium, silica, and sulfate show local maxima at the same depth of 25 mbsf (Fig. F27).

$\mathrm{Na}^{+}$concentrations of the interstitial water did not show significant downhole variation. However, significant increases of $\mathrm{Mg}^{2+}$ and $\mathrm{Ca}^{2+}$ and decreases of 
$\mathrm{K}^{+}$are observed from the seafloor to $\sim 35$ mbsf (i.e., seismic Reflector S10). Below 35 mbsf to $165 \mathrm{mbsf}$ (seismic Reflector S30), concentrations of $\mathrm{Mg}^{2+}, \mathrm{Ca}^{2+}$, and $\mathrm{K}^{+}$decrease. Between 240 and $280 \mathrm{mbsf}$, local maxima are obvious for $\mathrm{Na}^{+}, \mathrm{K}^{+}, \mathrm{Ca}^{2+}$, and $\mathrm{Mg}^{2+}$. Below $280 \mathrm{mbsf}$, the elemental concentrations stay relatively constant, except at 411 and 603 mbsf, where samples show significantly lower $\mathrm{Na}^{+}$and $\mathrm{Mg}^{2+}$ values (Fig. F28).

Downhole variations of $\mathrm{Li}^{+}, \mathrm{B}^{3+}$, and $\mathrm{Sr}^{2+}$ mimic those of $\mathrm{Ca}^{2+}$ and $\mathrm{Mg}^{2+}$. Concentrations of $\mathrm{Ba}^{2+}$ are generally low $(<1.7 \mu \mathrm{M})$ above $75 \mathrm{mbsf}$ in Hole U1324B. $\mathrm{Ba}^{2+}$ peaks at $23.2 \mu \mathrm{M}$ at $112 \mathrm{mbsf}$ (just below seismic Reflector S20) and decreases to $9.9 \mu \mathrm{M}$ at $150 \mathrm{mbsf}$. Between 150 mbsf and seismic Reflector S40, $\mathrm{Ba}^{2+}$ concentrations are constant at $\sim 10-12 \mu \mathrm{M}$. Below seismic Reflector S40, $\mathrm{Ba}^{2+}$ concentrations fluctuate between 9 and $21 \mu \mathrm{M}$. The deepest sample (603 mbsf) shows significantly lower $\mathrm{Sr}^{2+}$ and $\mathrm{Ba}^{2+}$ and higher $\mathrm{Li}^{+}$concentrations (Fig. F29). Dissolved $\mathrm{Mn}^{2+}$ concentrations decrease from $22.9 \mu \mathrm{M}$ at the seafloor to a minimum of $5.7 \mu \mathrm{M}$ by $\sim 25$ mbsf. Below 75 mbsf $\mathrm{Mn}^{2+}$ concentrations remain generally low, although the deepest sample shows an unusually high value of $25.2 \mu \mathrm{M}$. The interstitial water contains high concentrations of dissolved $\mathrm{Fe}^{2+}$ at shallow depths with local maxima of 479 and $354 \mu \mathrm{M}$ at 18 and 94 mbsf, respectively (Fig. F29). High dissolved $\mathrm{Fe}^{2+}$ caused iron oxyhydroxide precipitation (lepidocrocite, $\mathrm{FeO}[\mathrm{OH}]$, as deduced from XRD analyses of the precipitates) from the pore waters immediately after squeezing in the laboratory.

Eight pore water samples from Hole U1324C were also analyzed and show similar trends as the data from Hole U1324B.

In summary, the interstitial water chemistry at Site U1324 shows the largest variations at depths $<100$ mbsf. Below 100 mbsf, only limited changes are observed. Pronounced pore water chemical changes are particularly important from the seafloor to seismic Reflector $\mathrm{S} 10$ ( $\sim 35 \mathrm{mbsf}) . \mathrm{Li}^{+}, \mathrm{B}^{+}$, and $\mathrm{Sr}^{2+}$ maxima and $\mathrm{Mn}^{2+}$ minimum occur at $\sim 35-40 \mathrm{mbsf}$, whereas $\mathrm{H}_{4} \mathrm{SiO}_{4}$ and $\mathrm{Fe}^{2+}$ maxima occur between $\sim 20$ and 25 mbsf. Between seismic Reflectors S10 and S30, salinity, $\mathrm{Li}^{+}, \mathrm{B}^{3+}$, and $\mathrm{Sr}^{2+}$ decrease; $\mathrm{Ba}^{2+}, \mathrm{Fe}^{2+}$, and $\mathrm{NH}_{4}{ }^{+}$increase; and $\mathrm{Cl}^{-}, \mathrm{Mn}^{2+}$, and $\mathrm{H}_{4} \mathrm{SiO}_{4}$ remain constant. The extremely high $\mathrm{NH}_{4}{ }^{+}$content (up to $6820 \mu \mathrm{M}$ ) is consistent with more reducing conditions at this site in comparison with the sites drilled in Brazos-Trinity Basin IV. The general downhole increase in $\mathrm{NH}_{4}{ }^{+}$ likely reflects enhanced organic degradation at depth. The vertical profile, especially the surficial maximum and minimum in dissolved $\mathrm{Fe}^{2+}$ and $\mathrm{Mn}^{2+}$, are consistent with the hierarchy of redox reactions often observed in deep-marine sediments (Froelich et al., 1979). Elevated $\mathrm{Fe}^{2+}$ concentrations within shallow depths may reflect enhanced iron reduction and/or greater availability of detrital iron oxides/ oxyhydroxides or simply Fe-rich clays. The pore water chemistry at the seafloor is probably dominated by dissolution rather than organic matter degradation, which enhances alkalinity, $\mathrm{Ca}^{+}, \mathrm{Mg}^{2+}, \mathrm{Sr}^{2+}, \mathrm{B}^{3+}$, and $\mathrm{Li}^{+}$concentrations at $\sim 35 \mathrm{mbsf}$. The causes for the acidic nature of the pore water $(\mathrm{pH}<7)$ at depths above 200 mbsf are unclear.

\section{Solid-phase chemistry}

Initial results for total inorganic carbon (TIC), calcium carbonate $\left(\mathrm{CaCO}_{3}\right)$, total organic carbon (TOC), total nitrogen, molar ratio of organic carbon to total nitrogen $(\mathrm{C} / \mathrm{N})$, and total hydrogen analyses on sediment squeeze cakes are listed in Table T12 and presented in Figure F30. With the exception of total hydrogen concentrations above 205 mbsf, Hole U1324C elemental data are coincident with concentration data from Hole U1324B.

TIC concentrations range from 0.60 to $2.92 \mathrm{wt} \%$ (average $=1.85 \mathrm{wt} \%$ ). The organic-rich clays described in lithostratigraphic Subunit IA in the upper $15 \mathrm{mbsf}$ contain $<10 \mathrm{wt} \% \mathrm{CaCO}_{3}$. The color-banded laminations of green and red mud and clay within the remaining sections of lithostratigraphic Unit I are typically calcite rich, composed of $\sim 15 \mathrm{wt} \% \mathrm{CaCO}_{3}$. The TIC and $\mathrm{CaCO}_{3}$ curves exhibit a smooth transition between low and high concentrations from 49.3 to 332.1 mbsf. The excursion in inorganic carbon content observed in Section 308-U1324B-19H-3 at 166.5 mbsf is likely related to increased contribution of iron, indicated by the reddish color of the sediment (see Fig. F7). Inorganic carbon contents generally decrease with depth from 300 mbsf to 608 mbsf.

TOC contents are fairly uniform, ranging between 0.22 and $2.24 \mathrm{wt} \%$ (average $=0.75 \mathrm{wt} \%$ ). Results $\leq 0$ $\mathrm{wt} \%$ for Sections 308-U1324B-3H-3, 5H-5, 13H-3, and $69 \mathrm{X}-2$ and $308-\mathrm{U} 1324 \mathrm{C}-6 \mathrm{H}-2$ are an artifact of the method used to calculate TOC, where

$$
\mathrm{TOC}=\mathrm{TC}-\mathrm{TIC} \text {, }
$$

and are not included in the data analysis. TOC concentrations remain relatively constant downhole, with exception of a maximum in the upper $50 \mathrm{~m}$ that corresponds to organic-rich, black clays in lithostratigraphic Subunit IA. Mottled black sediments were observed throughout the color-banded laminations of lithostratigraphic Unit I and are likely related to increases in TOC concentrations at 198-227, 294-323, and 361 mbsf.

Nitrogen ranges from 0.10 to $0.53 \mathrm{wt} \%$ (average = $0.15 \mathrm{wt} \%)$. The total nitrogen curve is similar to the TOC curve, with the highest concentrations in or- 
ganic-rich layers. Hydrogen contents of the sediments range between 0.17 and $1.00 \mathrm{wt} \%$ (average = $0.64 \mathrm{wt} \%)$.

Molar C/N ratio ranges between 2.46 and 9.24 (average $=5.85$ ) (omitting results from Sections 308U1324B-3H-3, 5H-5, 13H-3, and 69X-2 and 308U1324C-6H-2). The broad range suggests fluctuations between hemipelagic and marine organic matter. The greatest $\mathrm{C} / \mathrm{N}$ variability in lithostratigraphic Unit I occurs within the organic-rich layers of Subunits IA and ID. C/N is fairly uniform within the carbonate-rich sediments. The jagged ratio trace below $300 \mathrm{mbsf}$ is associated with highly interbedded sand and silt layers in the lower portions of lithostratigraphic Unit I and throughout lithostratigraphic Unit II.

\section{Solid-phase initial interpretations}

TOC contents at Site U1324 are slightly higher than concentrations observed within sediments at Sites U1319 and U1320 (Brazos-Trinity Basin IV). An increase in available organic matter based on trends in the TOC, total nitrogen, and $\mathrm{C} / \mathrm{N}$ curves at $0-50$ and 320-608 mbsf suggests isolated periods of intensified organic matter sequestration possibly related to glacial-interglacial cycles and oxidation fronts associated with rapid sedimentation rates. The upper $60 \mathrm{~m}$ represents the Holocene/Pleistocene boundary (see Fig. F22). Within the top $50 \mathrm{~m}$, the maximum $\mathrm{C} / \mathrm{N}$ value of 9.09 suggests increased input of terrigenous material during sea level rise. Provenance of sedimentary organic matter may be better assessed with carbon and nitrogen isotopic analysis (Jasper and Gagosian, 1990). Rapid sedimentation rates estimated at $>25 \mathrm{~m} / \mathrm{k} . \mathrm{y}$. (see Fig. F22) may be responsible for the preservation of organic matter below 320 mbsf.

\section{Hydrocarbon gas composition}

\section{Organic geochemistry}

Headspace methane is shown in Figure F31. Rapid increases in methane concentration begin in the middle of lithostratigraphic Unit I, whereas there are only minor amounts of methane from seafloor to 160 mbsf. Methane was the predominant hydrocarbon species determined in Hole U1324B. Concentrations of hydrocarbon gas components are shown in Table T13. The calculated SMI depth is 94 mbsf (Fig. F32). This inverse correlation may suggest that methane results from methanogenesis, which is inhibited in the presence of sulfate. Minor amounts of ethane $(<3.5 \mathrm{ppmv})$ and ethylene $(<1.5 \mathrm{ppmv})$ were detected below $100 \mathrm{mbsf}$, coincident with localized peak methane concentrations (100-320 mbsf and/or 600 mbsf) (Fig. F31). No higher hydrocarbons were detected in Hole U1324B. When interpreting $\mathrm{C}_{1} / \mathrm{C}_{2}$ ratios, we need to consider that minor amounts of $\mathrm{C}_{2}$ (and $\mathrm{C}_{3}, \mathrm{C}_{4}$, and $\mathrm{C}_{5}$ ) compounds can also be generated in situ during early (low temperature) diagenesis of organic matter (e.g., Kvenvolden and Barnard, 1983). The $C_{1} / C_{2}$ ratios at Site U1324 are generally high, suggesting biogenic origin of the methane, which may be derived by in situ microbial activities or hydrogeologically driven migration. The almost exclusive presence of methane suggests that the hydrocarbon gases found at Site U1324 are of biogenic, not thermogenic, origin.

Methane concentrations fluctuate with depth. The two highest concentrations of methane were observed in the range of 40,339-41,620 ppmv at depths of 212 and 261 mbsf. According to the lithologic description, gas-bearing strata from 198 to $278 \mathrm{mbsf}$ are a mixed association of muds and clays within lithostratigraphic Unit I. These strata are positively correlated with slight increases in diagenetic ethane. In situ methanogenesis is expected to be minor considering the low abundance of subsurface microbes. Hence, the anomalously high concentrations in the middle part of lithostratigraphic Unit I are inferred to reflect fluid flow and transport. Stratigraphic accumulations occur in relatively permeable sediments and form largely from bacterial methane generated in situ or slowly migrated from depth in the section.

\section{Microbiology}

\section{Biomass enumeration}

The prokaryotic cell distribution in Hole U1329B was determined using whole-round core samples. The sampling frequency was one sample every 4-7 $\mathrm{m}$ between 2.8 and $27.2 \mathrm{mbsf}$, one sample every 8-10 m between 27.2 and $111.7 \mathrm{mbsf}$, and one sample every 15-30 m between 111.7 and 603.1 mbsf. The maximum cell density, which was $2.0 \times 10^{5}$ cells $/ \mathrm{mL}$, was observed at 2.8 mbsf. Cell density decreases with depth and was below detection limit $\left(1.0 \times 10^{4}\right.$ cells/ $\mathrm{mL}$ ) within $\sim 100$ mbsf with the exception of one sample at $131.8 \mathrm{mbsf}\left(2.8 \times 10^{4}\right.$ cells $\left./ \mathrm{mL}\right)$ (Fig. F33). The biomass of microbial cells at Site U1324 was unexpectedly small considering the location and high sedimentation rate of this site. The predominance of clay-rich sediment at Site U1324 is interpreted to explain the low microbial abundance (Table T14).

\section{Physical properties}

A downhole profile of physical properties was established for Site U1324 where the overburden above the Blue Unit is thickest relative to Sites U1322 and U1323. Physical properties are compared with those 
from Site U1322, where overburden above the Blue Unit is thinnest, and Site U1323, which has an intermediate overburden.

All cores were processed through the multisensor track (MST) before splitting. Initially, noncontact resistivity (NCR) and magnetic susceptibility measurements were taken at $2 \mathrm{~cm}$ intervals. $P$-wave logger (PWL) and gamma ray attenuation (GRA) densitometer measurements were taken at $4 \mathrm{~cm}$ intervals. All MST measurements were taken at $6 \mathrm{~cm}$ intervals from Core 308-U1324B-5H. PWL measurements were aborted after Core 308-U1324B-26H because of voids and cracks created by gas expansion.

Moisture and density (MAD) samples were selected from undisturbed cores at regularly spaced intervals $\sim 50 \mathrm{~cm}$ from the top of each section. They were used to calculate water content, bulk density, grain density, and porosity. An extra sample was taken $\sim 100$ $\mathrm{cm}$ from the top of each section from Cores 308U1324B-46X through 52X. The dry volume of these extra samples was not measured and, hence, grain density was not calculated because of time constraints and equipment capacity. Instead, the grain density of the sample from the MAD measurement at $50 \mathrm{~cm}$ in the same section was used to estimate the bulk density and porosity.

The discrete $P$-wave velocity (PWS) measurements only provided good data for cores above Core 308U1324B-28H due to extensive voids and fractures in the cores.

\section{Density and porosity}

Bulk density was determined from GRA on whole sections and from MAD measurements on discrete samples. Image-derived density (IDRO) from LWD data are discussed for comparison. Bulk densities determined from different methods are in good agreement in lithostratigraphic Unit I (Fig. F34A). There was considerable scatter of the LWD (IDRO) bulk density in lithostratigraphic Unit II. This is interpreted to be due to borehole washout when drilling through sandy-silty layers. The LWD (IDRO) densities had low values because it was partially measuring the water density when the borehole was washed out. LWD porosities were calculated assuming a grain density of $2.7 \mathrm{~g} / \mathrm{cm}^{3}$ and a pore water density of $1.024 \mathrm{~g} / \mathrm{cm}^{3}$. MAD porosities and LWD porosities are generally in good agreement.

MAD bulk densities rapidly increase from 1.27 to $\sim 1.7 \mathrm{~g} / \mathrm{cm}^{3}$ from the seafloor to $35 \mathrm{mbsf}$. Consequently, porosity values decrease from $80 \%$ to $55 \%$. A decrease in bulk density and increase in porosity at 35 mbsf correlates with seismic Reflector S10. From 35 to 160 mbsf, bulk density increases slightly from 1.7 to $2.0 \mathrm{~g} / \mathrm{cm}^{3}$. Correspondingly, porosity decreases from $55 \%$ to $45 \%$ (Fig. F34C). The sharp density decrease reflected by both the MAD and LWD data at 160 mbsf may be related to the silt layer above seismic Reflector S30 (see "Lithostratigraphy"). Below seismic Reflector S30 there is little increase in bulk density with depth; values range from $1.95 \mathrm{~g} / \mathrm{cm}^{3}$ immediately below seismic Reflector S30 to $2.05 \mathrm{~g} / \mathrm{cm}^{3}$ at the bottom of the hole. Porosity from MAD and LWD data shows little variation below seismic Reflector S30, with values decreasing gently from $48 \%$ to $40 \%$ with depth. Slight variations from this trend are observed at the top of lithostratigraphic Subunit IIA, with a small sudden increase in density, and within lithostratigraphic Subunit IIC, with a negative peak.

\section{Noncontact resistivity (NCR)}

NCR increases with depth from $0.36 \Omega \mathrm{m}$ at the seafloor to $\sim 1.5 \Omega \mathrm{m}$ at the bottom of the borehole (Fig. F35). NCR values increase with depth in lithostratigraphic Subunits IA and IB from $0.36 \Omega \mathrm{m}$ at the seafloor to $0.80 \Omega \mathrm{m}$ at $59.7 \mathrm{mbsf}$. In lithostratigraphic Subunits IC to IIB (59.7-481.9 mbsf), NCR values are more scattered than within the overlying lithostratigraphic units; these values range from 0.60 to $1.20 \Omega \mathrm{m}$. The scatter is more evident between 240 and 400 mbsf, which probably reflects gas voids and cracks, in addition to lithologic variability. The high variability in these intervals correlates with high methane concentrations in the pore water (see "Geochemistry and microbiology").

The lowest part of lithostratigraphic Subunit IIC (550-578.9 mbsf) has the highest resistivity values, while the sandy/silty layers within Subunit IID (578.9-608.0 mbsf) have NCR values similar to those of the upper part of Subunit IIC.

The resistivities from wireline logging data show a similar trend to that of MST measurements. However, wireline logging resistivities are generally higher, which probably results from measurement conditions, especially temperature contrast between laboratory and in situ conditions.

\section{Magnetic susceptibility logger}

Interpretations are based on uncorrected magnetic susceptibility (Fig. F36). Near-zero values or extremely high values were observed at the top and bottom of each section. These values are not included in the description of the data.

Lithostratigraphic Subunit IA shows an increase of magnetic susceptibility with depth from 0 to 22 mbsf that correlates with a rapid increase in bulk density (Fig. F34). From 22 mbsf to the base of litho- 
stratigraphic Subunit IA at 43.9 mbsf, a slight decrease in magnetic susceptibility can be observed (Fig. F36).

Magnetic susceptibility within lithostratigraphic Subunits IB (43.9-59.7 mbsf), IC (59.7-107 mbsf), and ID (107-116.8 mbsf) increases rapidly with depth until 160 mbsf and then, in lithostratigraphic Subunit IE (116.8-264.6 mbsf), decreases. The maximum value of magnetic susceptibility is correlated with a thin silt-rich interval that corresponds to seismic Reflector S30 (Fig. F36) almost at the top of lithostratigraphic Subunit IE. The lowest part of lithostratigraphic Unit I, including Subunits IF (264.8-288 mbsf) and IG (288-364.7 mbsf), shows again an increase in magnetic susceptibility from $\sim 65 \times 10^{-5}$ to $95 \times 10^{-5}$ SI. Magnetic susceptibility in lithostratigraphic Subunit IIA (364.7-445.5 mbsf) continues the trend of the interval above. This unit, corresponding to a thick interval of fining-upward silt/sand-rich turbidites alternating with muddy intervals (see "Lithostratigraphy"), does not display excursions as might be expected from the alternating lithologies.

Lithostratigraphic Subunit IIB (445.5-481.9 mbsf) is mainly composed of material deformed and remolded within MTDs (see "Lithostratigraphy"). This unit is characterized by very low magnetic susceptibility values, on the order of $45 \times 10^{-5}$ SI (Fig. F36). However, the rest of the MTDs at Site U1324 do not show similar excursions. The top of lithostratigraphic Subunit IIC shows values on the order of 100 $\times 10^{-5} \mathrm{SI}$, comparable to those in the lower part of Subunit IIA, and has decreasing values with increasing depth.

\section{Thermal conductivity}

Thermal conductivity increases rapidly with depth within lithostratigraphic Subunit IA and continues to increase with depth but less rapidly in lithostratigraphic Subunits IB and IC. Below lithostratigraphic Subunit IC, at 107 mbsf, there is almost no increase in thermal conductivity with depth, although the profile oscillates between 1 and $1.4 \mathrm{~W} /(\mathrm{m} \cdot \mathrm{K})$, centered around a mean of $1.2 \mathrm{~W} /(\mathrm{m} \cdot \mathrm{K})$ (Fig. F37). The trend in thermal conductivity mirrors that of the porosity: a rapid porosity decrease through lithostratigraphic Subunits IA-ID and a relatively constant porosity profile thereafter (Fig. F34).

\section{P-wave velocity}

The data from the PWS probes and the PWL correspond well (Fig. F38). The velocity rapidly and smoothly increases from 0 to 60 mbsf and then increases more moderately from 60 to 190 mbsf (Fig.
F38). No major shifts in $P$-wave velocity are observed when crossing from one lithostratigraphic unit to another. Velocity peaks in PWS data are relatively small in the uppermost $100 \mathrm{~m}$ and, from this depth downhole, the profile shows a more jagged pattern. The most important excursion recorded by PWS and PWL data is related to seismic Reflector S30, at $\sim 160$ mbsf. This low-velocity excursion is also evident in wireline logging data (Fig. F38).

$P$-wave velocities from wireline logging in Hole U1324B show substantial disagreement above seismic Reflector S20. Below this reflector the wireline logging values converge with PWS and PWL data (Fig. F38). This mismatch most probably results from the large borehole diameter above seismic Reflector S20, at 107 mbsf. The caliper log from LWD data in Hole U1324A shows a large hole diameter above 120 mbsf.

Below 220 mbsf, the wireline logging data show significant deviations from the smooth increase in velocity observed above. The first occurs between 220 and $260 \mathrm{mbsf}$, where wireline $P$-wave velocity decreases by $\sim 50 \mathrm{~m} / \mathrm{s}$ (Fig. F38). The caliper tool in Hole U1324A measured a large diameter in this interval, indicating that this decrease may be at least partially due to borehole washout. From 260 to 350 mbsf, near the top of lithostratigraphic Unit II, $P$ wave velocities continue to increase smoothly (Fig. F38). The wireline $P$-wave velocity $\log$ shows more irregular behavior from 350 mbsf downhole (lowest part of lithostratigraphic Subunit IG and lithostratigraphic Unit II). This is probably related to the alternating silt-sand-clay layers within this unit. Nevertheless, two intervals can be observed in Unit II. In the upper one (350-425 mbsf), velocities decrease from 1675 to $1650 \mathrm{~m} / \mathrm{s}$. The second one shows increasing velocities from 1675 to $1750 \mathrm{~m} / \mathrm{s}$.

$P$-wave velocity anisotropy was derived from PWS measurements. It is relatively small, with values $\sim 1 \%$, within lithostratigraphic Subunits IA, IB, and IC but increases in lithostratigraphic Subunit ID, especially below seismic Reflector S20, with mean anisotropies of $\sim 2 \%$.

\section{Undrained shear strength}

The undrained shear strengths measured by the AVS consistently match those measured with the pocket penetrometer (Fig. F39). Below 240 mbsf, the values measured by the penetrometer are systematically higher than those measured by the AVS, probably because the penetrometer measurements do not generate fractures whereas those of the AVS do.

Peak undrained shear strength increases downhole from near zero at the top of lithostratigraphic Unit I 
to $\sim 250 \mathrm{kPa}$ at $220 \mathrm{mbsf}$ (Fig. F39). The undrained shear strength is more scattered in lithostratigraphic Unit II. This is interpreted to be associated with the voids and fractures formed before and during measurements and the highly variable lithology. The upper part of the MTDs (440-480 mbsf) has higher undrained shear strength. This may result from a higher consolidation state of the sediments due to recompaction during the landslide process. An overall trend of decreasing shear strength with depth is shown in lithostratigraphic Subunits IIB and IIC. The shear strength increases from 540 to $580 \mathrm{mbsf}$ and then decreases to the bottom of the hole. The decrease in shear strength at the base of lithostratigraphic Subunit IIB is correlated to the presence of silty layers, whereas within lithostratigraphic Subunit IID, the low shear strengths correlate with the presence of sand layers within clay (measurements were always performed on the mudstone lithology).

Residual shear strength is highly variable (Fig. F39). This is partly explained by the difference in failure pattern after the shear vane reaches the undrained peak shear strength. Brittle failures isolate a plug around the shear vane, and the undrained residual shear strength is then very low. If the failure is caused without fracture the residual shear strengths are observed to be generally higher.

The sensitivity is generally intermediate (5-10) with a few peak values that indicate high sensitivity (Fig. F39). These peak values are associated with low residual shear strengths and reflect brittle failure rather than low disturbed shear strength.

In Figure F40, the peak shear strength is plotted and compared with iso-lines of the ratio between peak shear strength and the vertical hydrostatic effective stress (see "Physical properties" in the "Methods" chapter). The relation between the iso-lines and the peak undrained shear strength gives an indication of the consolidation state of the clay. At Site U1324 the peak undrained shear strength is not parallel to a particular iso-line. Within lithostratigraphic Subunits IA and IB, the undrained peak shear strength follows the 0.1 iso-line (Fig. F40). In Lithostratigraphic Subunit IC the peak shear strength moves toward the lower iso-lines 0.05 and 0.025 .

\section{Summary}

Variations in physical properties correlate with lithostratigraphic units (see "Lithostratigraphy"). The interbedded silt, sand, mud, and MTDs in lithostratigraphic Unit II are characterized by highly variable bulk density and porosity. Physical properties show much less scatter within the uniform hemipelagic mud and clay in lithostratigraphic Unit I.

Bulk density, porosity, noncontact resistivity, thermal conductivity, and $P$-wave velocity data are mutually dependent. Porosity decreases rapidly from the seafloor to $35 \mathrm{mbsf}$ and then slowly to $160 \mathrm{mbsf}$. There is only a slight decrease in porosity below 160 mbsf to the bottom of the hole. This trend is also reflected on the bulk density, NCR, $P$-wave velocity, and thermal conductivity data. Almost no decrease in porosity with depth below 160 mbsf suggests that these sediments are underconsolidated and overpressured. This explanation is supported by the high sedimentation rates described in "Biostratigraphy."

There is no significant difference in physical properties between the MTDs and the nondeformed sedimentary successions in lithostratigraphic Unit I at Site U1324, suggesting that these MTDs remained relatively intact during transport and probably have not moved significant distances from their original deposition location. This explanation is supported by the mild deformation observed in these intervals (see "Lithostratigraphy").

Undrained peak shear strength shows larger oscillations within lithostratigraphic Unit II. It generally increases with depth from a low at the boundary between lithostratigraphic Units I and II until the bottom of the hole. However, major reductions in shear strength occur at $\sim 520 \mathrm{mbsf}$, at the base of a major MTD, and at $\sim 590$ mbsf.

Lithostratigraphic Subunits IB and ID correspond to MTDs at Sites U1322 and U1324. The trends in porosity and undrained shear strength are similar at both sites. However, the porosity and undrained shear strength profiles at Site U1324 (Figs. F34C, F40B) show more subdued variations (or no variation at all) between MTDs and undisturbed units than those at Site U1322 (Figs. F34C, F40B). It is possible that at Site U1324, upslope on the Mississippi Canyon levee, the velocity of landslides might have been lower than that at Site U1322, in the center of the basin, and thus the amount of shearing and deformation might also have been lower. Higher shearing at Site U1322 would then translate into a higher degree of consolidation.

\section{Downhole measurements}

Downhole measurements at Site U1324 were used to characterize pressure, temperature, and rock properties within the mudstone-dominated sedimentary section above the Blue Unit. 


\section{Logging while drilling and measurement while drilling}

\section{Operations}

LWD/MWD operations in Hole U1324A used the same BHA, tool configuration, and protocols as those for at Sites U1322 and U1323. (see "Downhole measurements" and "Summary of operations" in the "Site 1322" chapter). Batteries were replaced in the LWD tools prior to drilling. The hole was initiated with a rapid jet-in to 8 mbsf before retrieving the VIT camera. After the VIT camera was recovered, bit rotation and pump rates of $50 \mathrm{rpm}$ and $60 \mathrm{gpm}$ were used to 25 mbsf while maintaining an ROP of $30 \mathrm{~m} / \mathrm{h}$. From 25 to $35 \mathrm{mbsf}$, pump rates were increased gradually to $400 \mathrm{gpm}$. Below 35 to $\sim 612$ mbsf, an ROP of $30 \mathrm{~m} / \mathrm{h}$ and pump rates of at least $400 \mathrm{gpm}$ were maintained. The interval from 472 to 612 mbsf was drilled using 10.5 ppg mud (seawater, sepiolite, and barite). One sand interval $>1.5 \mathrm{~m}$ was encountered, and as result the hole was cemented according to IODP Expedition 308 operations protocol.

\section{Logging data quality}

Figure F41 shows the LWD quality control logs. The target ROP of $30 \mathrm{~m} / \mathrm{h}( \pm 5 \mathrm{~m} / \mathrm{h})$ was achieved except during jet-in (Fig. F41). The density-derived caliper log (DCAV) documents good borehole conditions from 130 to 612 mbsf (Fig. F41). Enlarged borehole dimensions, however, existed from 378 to 420 and 509 to 520 mbsf. The bulk density correction (IDDR) for the entire borehole varies from -0.1 to $0.2 \mathrm{~g} / \mathrm{cm}^{3}$ $\left(\right.$ mean $\left.=0.02 \mathrm{~g} / \mathrm{cm}^{3}\right)$ (Fig. F41), which was larger than in previous holes. The largest variations are concentrated in enlarged borehole intervals.

LWD logs were depth-shifted by identifying the seafloor in the gamma ray data. For Hole U1324B, the gamma ray pick for the seafloor was at $1466.5 \mathrm{mbrf}$, $0.4 \mathrm{~m}$ deeper than the drillers depth. The rig floor logging datum was located $10.6 \mathrm{~m}$ above sea level.

\section{Annular pressure while drilling and equivalent circulating density}

Pressure within the borehole was monitored during MWD/LWD operations (see discussion in "Array resistivity compensated tool" in "Downhole measurements" in the "Methods" chapter) as annular pressure while drilling in excess of hydrostatic $\left(\mathrm{APWD}^{*}\right)$ and equivalent circulating density referenced to the seafloor $\left(\mathrm{ECD}_{\text {rsf }}\right) . \mathrm{ECD}_{\mathrm{rsf}}$ decreases from 0 to $300 \mathrm{mbsf}$ and then gradually increases from 300 to 470 mbsf (Fig. F42). APWD* gradually increases with depth from 0 to 470 mbsf. At 470 mbsf, 10.5 ppg mud (seawater, sepiolite, and barite) was circulated while drilling. The weighted mud created step increases in $\mathrm{ECD}_{\text {rsf }}$ and $\mathrm{APWD}^{*}$.

\section{LWD results}

Operations in Hole U1324A drilled through a series of interbedded clay, mud, and sand units as well as several MTDs from 0 to 612 mbsf. The hole quality from 0 to 65 mbsf is highly variable, with caliper measurements reaching at least $42 \mathrm{~cm}$. Below 65 mbsf, the caliper measured an average hole diameter of $25.9 \mathrm{~cm}$, with washouts at $\sim 244,328,378$, and 509 mbsf.

The GeoVision Resistivity (GVR) tool gamma ray log has minor variations through lithostratigraphic Unit I. Lithostratigraphic Unit I was predominantly composed of clay and mud with rare occurrences of silt and sand. Gamma radiation in lithostratigraphic Unit I increases with depth, and the most significant deviation occurs at $\sim 160 \mathrm{mbsf}$, which corresponds to seismic Reflector S30 (Fig. F43). This interval is characterized by lower gamma radiation and is interpreted as a silty sand layer. Lithostratigraphic Unit II, predominantly composed of interbedded silt and very fine sand with beds and laminae of mud and clay, shows more gamma ray variability than lithostratigraphic Unit I. Gamma radiation ranges from 26.4 to 92.4 gAPI, which suggests distinct changes in lithology from sand-rich to mud intervals (Fig. F43).

GVR deep button resistivity increases from 0.3 to 2.2 $\Omega \mathrm{m}$ from the seafloor to $365 \mathrm{mbsf}$ (Fig. F43). Variations in deep resistivity are interpreted as occurrences of sand and silt within lithostratigraphic Unit I. The GVR shallow button resistivity shows larger variations above 100 mbsf, due to variable hole conditions that are most likely caused by drilling disturbances (Fig. F43). Deep resistivity measurements show a wider range of values within lithostratigraphic Unit II (365-608 mbsf), where resistivity varies from 0.5 to $3.6 \Omega \mathrm{m}$ (mean $=1.5 \Omega \mathrm{m})$. These variations reflect greater sand content within lithostratigraphic Unit II.

Vision Density Neutron (VDN) bulk density increases from $1.0 \mathrm{~g} / \mathrm{cm}^{3}$ near the seafloor to $2.2 \mathrm{~g} / \mathrm{cm}^{3}$ near the bottom of the hole (Fig. F43). A comparison of LWD bulk density with core MAD measurements shows an excellent correlation throughout most of the hole except for washed-out intervals in lithostratigraphic Subunits IIA and IIC (Fig. F43). Neutron porosity decreases from $86.5 \%$ to $38 \%$, with the largest downhole porosity fluctuations occurring in sand-rich intervals within lithostratigraphic Subunit IIA (Fig. F43). The photoelectric factor log from Hole 
U1324B follows similar trends as those observed in the gamma ray profile except below $472 \mathrm{mbsf}$, when of heavy mud containing barite affected the measurements (Fig. F43).

Resistivity images show deformation in the hemipelagic drape and distal turbidites drilled in Hole U1324A (Fig. F43). Lithostratigraphic Subunit ID is composed of faulted and contorted reddish brown and greenish gray clay (see "Lithostratigraphy"). Resistivity images in Subunits ID and IE reveal dipping beds $\left(5^{\circ}-55^{\circ}\right)$ throughout these intervals that are consistent with core observations (Fig. F44). Steep deformed beds with dips as high as $65^{\circ}$, corresponding to the top of lithostratigraphic Subunit IE, exist just above seismic Reflector S30 (Fig. F44).

Lithostratigraphic Unit II shows large amounts of deformation as contorted and faulted beds indicative of downslope remobilization (Fig. F45). This unit is interpreted as MTDs (see "Lithostratigraphy"). Steep dips and folds in the resistivity images suggest the presence of overturned beds in lithostratigraphic Subunit IIA. Scoured surfaces, interpreted as erosional episodes, are imaged in lithostratigraphic Subunit IIC (Fig. F46). A fold with an east-west-trending axis found in lithostratigraphic Subunit IID confirms significant deformation in this subunit (Fig. F47). Most of the deformation features observed within Hole U1324A trend in an east-west direction, with the majority dipping to the north.

\section{Wireline logging}

\section{Operations}

Wireline tools were deployed in Hole U1324A to obtain velocity data (Fig. F48). A tool string consisting of the HNGS, DSI, and GPIT was deployed first (see "Downhole measurements" in the "Methods" chapter), with the drill pipe at $\sim 54$ mbsf. A downhole $\log$ was recorded at $550 \mathrm{~m} / \mathrm{h}$ from the seafloor to 59 mbsf. The tool string was then stuck either with the lower DSI centralizer on the lockable float valve or the go-devil at the end of the tool string hitting the borehole wall. We pulled the pipe up $5 \mathrm{~m}$ and then successfully lowered the tool string into the borehole. The pipe was left at 49 mbsf. We started the first logging pass from 507 mbsf. We measured gamma radiation, including spectral data, and $P$ - and $S$-wave (P\&S) mode at $15 \mathrm{~Hz}$ sampling rate. Logging proceeded at $275 \mathrm{~m} / \mathrm{h}$ to $84 \mathrm{mbsf}$. We then lowered the tool string for a second pass starting from 509.5 mbsf. The second pass recorded gamma radiation, $P \& S$, low-frequency lower dipole, and Stoneley modes at $15 \mathrm{~Hz}$ sampling rate.
The second wireline tool string deployed consisted of the Well Seismic Tool for a check shot survey (see "Downhole logging" in the "Methods" chapter).

Sixteen stations were targeted at $\sim 25 \mathrm{~m}$ intervals (Table T15). The generator-injector gun had a 45 in $^{3}$ generator chamber volume and a 105 in $^{3}$ injector chamber volume and a total pressure of 2000 psi. The recording length was $5 \mathrm{~s}$ with a $1 \mathrm{~ms}$ sampling rate and a $40 \mathrm{~ms}$ delay. The rig floor preparations for wireline logging operations began on 19 June 2005 at $1905 \mathrm{~h}$ and were completed by 20 June at $1255 \mathrm{~h}$.

\section{Logging data quality}

The wireline data were depth-shifted based on a seafloor depth of $1066.5 \mathrm{mbsf}$ determined by gamma ray logs. HNGS data were not corrected for borehole diameter variations or mud weight.

\section{Wireline results}

HNGS gamma ray measurements are in good agreement with those of the GVR. The spectral measurements $\left({ }^{40} \mathrm{~K},{ }^{232} \mathrm{Th}\right.$, and ${ }^{238} \mathrm{U}$ isotopes) show that the decay of ${ }^{232} \mathrm{Th}$ is the primary gamma ray contributor (Fig. F48.) The range of ${ }^{232} \mathrm{Th}$ values measured in Hole U1324A fall within values reported for illite and smectite (Rider, 1996).

In Hole U1324A we collected wireline sonic data and check shot data to evaluate velocity between 83.8 and 498.9 mbsf (Table T15; Fig. F48). Compressional wave velocities (wireline log) to $501.9 \mathrm{mbsf}$ generally increase from 1486 to $1834 \mathrm{~m} / \mathrm{s}$ with depth, whereas the interval velocities from the check shot increase from 1583 to $1852 \mathrm{~m} / \mathrm{s}$ (Fig. F48).

Before obtaining velocity measurements at Site U1324, the only available time-depth information for the Ursa Basin site was based on nearby check shot surveys (see Equation 1 in the "Site U1322" chapter). This time-to-depth conversion is plotted with check shot and sonic log data (Fig. F49).

\section{Core-log-seismic integration}

Lithostratigraphic Unit I (0-364.7 mbsf) is described as hemipelagic drape and very distal turbidites from channel-levee systems to the west and is divided into seven subunits (see "Lithostratigraphy"). Lithostratigraphic Unit II (364.7-600.8 mbsf) includes four subunits and marks a change in lithology that includes interbedded silt and very fine sand with beds and laminae of mud and clay. Several MTDs within this unit are potentially associated with the depositional environment of the Southwest Pass Canyon channel-levee system (see "Lithostratigraphy"). 
Most of the lithostratigraphic subdivisions correlate with log responses (Fig. F50). Based on gamma radiation, resistivity, bulk density, and compressional wave velocity log responses, five fining-upward and fining-downward sequences were identified within lithostratigraphic Unit II. This correlates well with variations in sand content in cores. Four out of five of these zones correlate closely with the tops of lithostratigraphic subunits; the exception is from 400 to 422 mbsf within lithostratigraphic Subunit IIA and seems to be the thickest sand sequence (Fig. F51).

We used LWD density data and the wireline sonic log to construct a synthetic seismogram for Hole U1324B (Fig. F50). Reflection coefficients were calculated using the LWD density data and a constant compressional wave velocity of $1600 \mathrm{~m} / \mathrm{s}$ from 0 to $50 \mathrm{mbsf}$ and the wireline velocity below $50 \mathrm{mbsf}$. A $150 \mathrm{~Hz}$ minimum-phase, Ricker wavelet was convolved with the reflection coefficients to create the synthetic seismogram. The correlation of events between the synthetic seismogram and the high-resolution seismic indicates that the time-depth model is appropriate for these sediments. An accurate timedepth model allows correlation of seismic reflections with observations in core and logging data.

A decrease in gamma radiation and bulk density correlates with seismic Reflector S10 (Figs. F24, F51). The top of lithostratigraphic Subunit ID is defined by an increase in velocity and a subtle change in resistivity (Figs. F50, F51). The top of lithostratigraphic Subunit IE is interpreted as a transition from an overlying MTD to a series clay laminae and thin beds enriched in foraminifers and nannofossils (see "Lithostratigraphy"). The upper part of this subunit is characterized by high gamma radiation, low density, and low velocity. A low-density zone correlates with seismic Reflector S30 (Figs. F50, F51). Seismic reflectors S40-1324 and S50-1324 correlate with zones interpreted as potential low-relief channels containing silt and sand deposits. The synthetic seismogram shows an apparent offset with the regional seismic data suggesting that the shallow velocity may have been too fast (Fig. F50). The synthetic seismogram matches the frequency and amplitude of signals observed in the seismic data except in lithostratigraphic Unit II, where the high-amplitude reflections, due to low densities, are frequent. These low densities may be the result of degraded borehole conditions.

\section{Temperature and pressure measurements}

In situ measurements made with the APCT tool, the T2P, and the DVTPP documented overpressure and a low thermal gradient relative to Site U1322.

\section{Advanced piston corer temperature tool}

The APCT tool was deployed four times in Hole U1324B (Table T16). Temperature was measured in the sediment for $10 \mathrm{~min}$ to establish the temperature decay curve. Extrapolation of the temperature decay curve with an assumed thermal conductivity of 1.2 $\mathrm{W} /(\mathrm{m} \cdot \mathrm{K})$ was used to estimate in situ formation temperatures. The first deployment at $51.3 \mathrm{mbsf}$ (Core 308-U1324B-6H) provided an in situ temperature of $5.66^{\circ} \mathrm{C}$ (Fig. F52). The second deployment (79.8 mbsf; Core 308-U1324B-9H) yielded an equilibrium temperature of $6.32^{\circ} \mathrm{C}$ (Fig. F53). The third deployment was at $108.3 \mathrm{mbsf}$ (Core 308-U1324B-12H) and yielded an equilibrium temperature of $6.40^{\circ} \mathrm{C}$ (Fig. F54). The final deployment occurred at $136.3 \mathrm{mbsf}$ (Core 308-U1324B-15H) and provided a formation temperature of $7.50^{\circ} \mathrm{C}$ (Fig. F55).

\section{Temperature/Dual Pressure Probe}

Twelve deployments of the T2P were completed at Site 1324 (Table T16). These measurements provided numerous constraints on in situ temperature and some constraints on formation pressures.

\section{T2P Deployment 5}

All sensors recorded an increase during penetration into the formation during T2P Deployment 5 (Table T17; Fig. F56). The tip pressure decreased after penetration and achieved nearly constant pressure at 11.0 $\mathrm{MPa}$. The hydrostatic reference was $11.13 \mathrm{MPa}$. The shaft sensor recorded a small pressure increase followed by minimal dissipation to $11.9 \mathrm{MPa}$. A pressure difference between the tip and shaft was recorded while lowering the tool downhole. The temperature record was continuous and smooth to its final temperature of $5.57^{\circ} \mathrm{C}$. Data recording stopped upon pulling the tool out of the formation. At the rig floor, it was noted that the T2P tip was bent and the thermistor and bottom porous stone were missing from the tool. We believe the tool was bent during penetration and broken when pulling the tool out of the formation. Data may not reflect in situ conditions because of probe damage.

\section{T2P Deployment 6}

Pressure and temperature data for T2P Deployment 6 show multiple pulses and decays (Table T18; Fig. F57). The first increase in all sensors occurred when the CDS landed in the BHA, the second increase in the tip and shaft pressure coincided with pushing into the formation, and the third increase occurred when circulation began (Table T18; Fig. F57). The tip pressure went subhydrostatic (hydrostatic pressure = $11.51 \mathrm{MPa}$ ), after which it slowly increased to 11.7 
MPa. Subhydrostatic pressure may have resulted from an internal leak or a small void near the tip caused when the drill bit was picked up. The shaft pressure dissipated to $12.7 \mathrm{MPa}$. The temperature was decreasing when the tool was recovered and did not reach an equilibrium value. This continual decrease in temperature suggested there was a leak in the system that removed heat.

\section{T2P Deployment 7}

During T2P Deployment 7, pressure and temperature responded to initial landing of the CDS in the BHA, pushing into to the formation, and circulation of drilling fluid (Table T19; Fig. F58). The tip pressure decreased to $12.0 \mathrm{MPa}$; however, the response was erratic. The shaft had a small pressure increase and declined to a final pressure of $13.3 \mathrm{MPa}$. Hydrostatic pressure was $11.80 \mathrm{MPa}$. The small shaft pressure increase may have indicated incomplete penetration into the formation. The temperature data provided an in situ temperature estimate of $6.81^{\circ} \mathrm{C}$.

\section{T2P Deployment 8}

The tip pressure and temperature increased with penetration during T2P Deployment 8 (Table T20; Fig. F59). The tip pressure eventually increased to $12.4 \mathrm{MPa}$. The hydrostatic reference was $11.99 \mathrm{MPa}$. The temperature profile equilibrated to a formation temperature of $7.20^{\circ} \mathrm{C}$. The shaft pressure response was erratic throughout the deployment, with multiple step increases and decreases in pressure that were not associated with deployment events. Because of the poor pressure readings the tool was disassembled and reassembled to establish good seals and electrical connections.

\section{T2P Deployment 9}

T2P Deployment 9 exhibited large pressure and temperature responses when the tool landed in the BHA and when it penetrated the formation (Table T21; Fig. F60). These responses were immediately followed by decreases. We interpreted that the tool was coupled with the drill bit; therefore, when the bit was picked up, the tool was pulled out of the sediment. A large offset between the tip and shaft pressure was also a problem. Because of deployment and calibration problems, no in situ conditions could be evaluated.

\section{T2P Deployment 10}

T2P Deployment 10 is documented in Table T22. An electronic problem that occurred after placing the tool on the rig floor precluded collection of any downhole data. Upon recovery of the tool, it was determined that the connection between the sensors and the data acquisition system was poor. To remedy this problem, the tool was dismantled, all connections were cleaned, and the tool was reassembled.

\section{T2P Deployment 11}

T2P Deployment 11 tested the sensors and data acquisition system. The probe was not pushed into the sediment (Table T23). Data recorded for the deployment show excellent agreement between the tip and shaft pressure sensors (Fig. F61). Two pressure decreases occurred at the tip. These may have been caused by the tip being partly embedded in the sediment. The shaft did not penetrate the formation. Overall, the Deployment 10 confirmed that the electronic failure from T2P deployment had been fixed.

\section{T2P Deployment 12}

T2P Deployment 12 showed pressure and temperature increases during landing of the CDS in the BHA and during penetration into the formation (Table T24; Fig. F62). The tip pressure decreased rapidly and then slowly dissipated to $11.0 \mathrm{MPa}$ (hydrostatic pressure $=11.10 \mathrm{MPa}$ ). The shaft pressure increased and then dissipated to $11.4 \mathrm{MPa}$. From the slow dissipation of shaft pressure we inferred low permeability of the sediments. The temperature profile recorded a final temperature of $5.46^{\circ} \mathrm{C}$, which was assumed to represent in situ conditions.

\section{T2P Deployment 13}

All sensors increased with penetration into the sediment during T2P Deployment 13 (Table T25; Fig. F63). Pressures then dissipated until the tool was pulled out of the formation. The tip had a pressure decrease coincident with picking up the bit. End pressures of $12.0 \mathrm{MPa}$ (tip) and $12.2 \mathrm{MPa}$ (shaft) exceeded hydrostatic pressure $(11.61 \mathrm{MPa})$. The temperature profile exhibited decay to an estimated in situ temperature of $6.40^{\circ} \mathrm{C}$.

\section{T2P Deployment 14}

Similar to Deployment 13, pressure and temperature increased with penetration into the sediment, followed by dissipation curves during T2P Deployment 14 (Table T26; Fig. F64). All sensors recorded a perturbation while in the formation that could not be attributed to deployment activities (Table T26). After this perturbation, temperature and shaft pressure continued to dissipate. The tip pressure had a larger decrease followed by a pressure increase. The end pressures of 12.7 MPa (tip) and 13.0 MPa (shaft) exceed hydrostatic $(12.11 \mathrm{MPa})$. The temperature $\left(7.31^{\circ} \mathrm{C}\right)$ appeared to be in equilibrium with the formation. 


\section{T2P Deployment 15}

T2P Deployment 15 provided useful shaft pressure and temperature data; however, tip pressure data were less reliable. All data increased during penetration followed by dissipation curves (Table T27; Fig. F65). No data were recorded during retrieval of the tool from the sediment. The tip pressure decreased after penetration, then recovered and dissipated to 13.8 MPa. The shaft pressure dissipated to $14.3 \mathrm{MPa}$. Hydrostatic pressure was $12.61 \mathrm{MPa}$. The temperature decay was rapid to $8.27^{\circ} \mathrm{C}$. We interpreted this to be the formation temperature. When the tool reached the rig floor, it was confirmed that the tip was bent and the drive tube was loose. The loosening of the drive tube most likely caused the failure to record data during tool retrieval.

\section{T2P Deployment 16}

The pressure and temperature data are excellent for T2P Deployment 16 (Table T28; Fig. F66). Pressure and temperature increased during penetration, which was followed by continuous dissipation curves. The end pressure of $13.9 \mathrm{MPa}$ (tip) may have been in equilibrium with the formation. The hydrostatic reference was $13.62 \mathrm{MPa}$. Temperature equilibrated with the formation at $9.97^{\circ} \mathrm{C}$.

\section{Davis-Villinger Temperature-Pressure Probe}

Thirteen DVTPP deployments were competed at Site U1324 (229.1-608.1 mbsf) to provide additional constraints on formation pressure and temperature (Table T16).

\section{DVTPP Deployment 3}

After penetration during DVTPP Deployment 3, the pressure rapidly decreased followed by a slow pressure increase (Fig. F67). It was believed an internal leak or a pressure drop caused by a void when picking up the drill string, caused this response. The slow, continuous pressure increase most likely indicated the latter. A final pressure of $13.1 \mathrm{MPa}$ was nearly constant and may be near in situ conditions; hydrostatic pressure was $12.92 \mathrm{MPa}$. The temperature profile provided an equilibrium temperature of $9.52^{\circ} \mathrm{C}$ (Fig. F67).

\section{DVTPP Deployment 4}

Similar to DVTPP Deployment 3, the temperature record provided in situ conditions during DVTPP Deployment $4\left(11.68^{\circ} \mathrm{C}\right)$, whereas the pressure record was problematic (Fig. F68). Pressure decreased rapidly after insertion and then had increase/decrease cycles. We interpreted this was caused by an internal leak; as the pressure reached a high value, fluid pres- sure leaked into the tool pressure housing, which in turn caused a rapid decrease; the pressure then slowly increased until it leaked again. This prompted a rebuild of the DVTPP to seal internal leaks.

\section{DVTPP Deployment 5}

No data were recorded for DVTPP Deployment 5.

\section{DVTPP Deployment 6}

DVTPP Deployment 6 provided an equilibrium temperature $\left(12.96^{\circ} \mathrm{C}\right)$ (Fig. F69). Pressure increased with penetration and then decreased rapidly when the bit was picked up from the bottom of the hole. A slow pressure rebound was then recorded. It was believed the tool was partly pulled up with the drill bit, and this created a void around the pressure sensor. As the void equilibrated with the formation, pressure increased to $14.9 \mathrm{MPa}$, which is less than hydrostatic pressure $(15.28 \mathrm{MPa})$. Pressure was still increasing when the DVTPP was retrieved.

\section{DVTPP Deployment 7}

During DVTPP Deployment 7 the temperature profile had a type dissipation curve but the pressure profile exhibited a low-pressure excursion after picking up the bit off the bottom of the hole (Fig. F70). The equilibrium temperature was estimated to be $13.46^{\circ} \mathrm{C}$. The pressure decreased to a value significantly below hydrostatic (hydrostatic pressure = $15.57 \mathrm{MPa}$ ) and then slowly increased to $12.9 \mathrm{MPa}$. The increase may have reflected charging of a void with formation fluids. Fluid pressure was still increasing at the end of the experiment.

\section{DVTPP Deployment 8}

In DVTPP Deployment 8 the temperature spiked at penetration followed by decay to an in situ temperature of $13.84^{\circ} \mathrm{C}$ (Fig. F71). The pressure record for this deployment was significantly less than hydrostatic (hydrostatic $=15.86 \mathrm{MPa}$ ) and did not record any penetration pressure or dissipation (Fig. F71). This poor pressure result prompted a change in the DVTPP being deployed while the tool used in this deployment was rebuilt.

\section{DVTPP Deployment 9}

A programming error occurred during DVTPP Deployment 9. No data were recorded.

\section{DVTPP Deployment 10}

Pressure and temperature dissipation profiles increased with penetration and then decreased during DVTPP Deployment 10 (Fig. F72). Temperature followed a decay curve to a formation temperature of 
$15.81^{\circ} \mathrm{C}$. Pressure dissipated while the tool was in the formation, but only to $19.9 \mathrm{MPa}$, in contrast to hydrostatic pressure of $16.75 \mathrm{MPa}$. The pressure dissipation was far from reaching equilibrium.

\section{DVTPP Deployment 11}

The temperature and pressure sensors recorded unreliable data during DVTPP Deployment 11 (Fig. F73).

\section{DVTPP Deployment 12}

During DVTPP Deployment 12, pressure increased during penetration, then quickly declined, and then recovered rapidly. The pressure ultimately dissipated to $18.9 \mathrm{MPa}$ (Fig. F74). This dissipation was not yet in equilibrium with the formation. The temperature increased rapidly during penetration and then dissipated. The equilibrium temperature was $17.16^{\circ} \mathrm{C}$ (Fig. F74).

\section{DVTPP Deployment 13}

Pressure and temperature profiles were recorded during and after penetration during DVTPP Deployment 13 (Fig. F75). Temperature decayed to an in situ value of $11.11^{\circ} \mathrm{C}$. The pressure profile dissipated to 14.7 MPa but had not yet equilibrated with the formation. Hydrostatic pressure was $13.12 \mathrm{MPa}$.

\section{DVTPP Deployment 14}

During DVTPP Deployment 14, pressure and temperature data had regular profiles. Pressure increased slightly during penetration and then dropped rapidly to $15.8 \mathrm{MPa}$ (Fig. F76), which exceeded hydrostatic $(14.67 \mathrm{MPa})$. Temperature increased rapidly and then decreased rapidly when the bit was picked up off the bottom of the hole. Near the end of the deployment, temperature increased to a final value of $11.2^{\circ} \mathrm{C}$. No explanation was available for the small temperature increase at the end of the deployment.

\section{DVTPP Deployment 15}

Similar to DVTPP Deployment 14, during DVTPP Deployment 15, pressure increased, then decreased, and slowly increased to $16.9 \mathrm{MPa}$ (Fig. F77), which exceeded hydrostatic pressure $(15.68 \mathrm{MPa})$. The temperature reading was more problematic than DVTPP Deployment 14 . The end temperature of $13.63^{\circ} \mathrm{C}$ most likely is not representative of in situ conditions.

\section{Temperature and pressure summary}

APCT, T2P, and DVTPP measurements help constrain the thermal gradient and the pressure field at Site U1324. Temperature measurements increased approximately linearly with depth (Fig. F78). Regression of temperatures provided a thermal gradient of $18.4^{\circ} \mathrm{C} / \mathrm{km}$. The largest scatter between the data and the average gradient occurred between 200 and 400 mbsf and below 550 mbsf. In the 200-400 mbsf interval, deviations may reflect lithology variation, deployment duration, or coupling between the probe and the sediment.

Two summaries of the pressure field were extracted from pressure measurements. The first included the pressure data (Fig. F79) where both pressure increases during penetration and dissipation curves were recorded. These data provided a maximum estimate of pressure, as complete dissipation was not achieved. Deviations of the last measured pressure (Fig. F79) and the in situ pressure were a function of the initial pressure spike (a function of probe geometry) and the amount of time the tool was left in the formation (Table T16).

The second pressure interpretation included reliable dissipation pressures (Fig. F79) and pressures measured that were interpreted as recovery from a void created near the tip of the probe. In multiple deployments, it was interpreted that a void was created near the tip of the probe when the drill bit was picked up. The pressure then rebounded as the void started to equilibrate with the formation fluid. The pressures (Fig. F80) were the final pressures measured by the probe prior to removal from the formation and represent a minimum bound on pressure. These data, although not finalized, were interpreted to document fluid overpressure from 50 to $608 \mathrm{mbsf}$ at Site U1324.

\section{Summary}

Site U1324 logging data provided a detailed picture of the bedding style and lithofacies overlying the Blue Unit. Detailed core-log data integration at Sites U1322 and U1323 will enable refinement of the interpretation, but our preliminary interpretation provided the following insights:

- The main lithostratigraphic units defined in cores correlate with variations in LWD and wireline logs responses.

- Gamma ray, resistivity, bulk density, and compressional wave velocity log responses define five intervals within lithostratigraphic Unit II that are associated with fining-upward and fining-downward sequences.

- Resistivity images show significant deformation (dipping beds from $5^{\circ}$ to $55^{\circ}$ ) of the overlying hemipelagic drape and distal turbidites from the Southwest Pass Canyon sediments. Steeply deformed beds with dips as high as $65^{\circ}$ and folded and faulted beds suggest downslope remobilization as MTDs. Resistivity images show evidence of these MTDs in lithostratigraphic Subunit IIA, 
where steep dips and folds suggest a succession of sand-silt-mud laminae. Most of the deformation features observed in Hole U1324A trend in an east-west direction with the majority dipping to the north.

- A correlation between seismic data, well logs, and synthetic seismograms shows a good match between seismic reflectors. In the case of lithostratigraphic Subunit IE, faulted and contorted clay units with steeply dipping beds show an acoustically transparent nature in both the seismic data and the synthetic model.

- In situ temperature and pressure measurements documented overpressure and a low thermal gradient at Site U1324. Successful fluid pressure measurements yield $\lambda^{*}$ values between 0.2 and 0.6 at the end of the deployment:

where

$$
\lambda^{*}=\left(P-P_{\mathrm{h}}\right) /\left(\sigma_{\mathrm{v}}-P_{\mathrm{h}}\right),
$$

$$
\begin{aligned}
& P=\text { pressure, } \\
& P_{\mathrm{h}}=\text { hydrostatic pressure, and } \\
& \sigma_{\mathrm{v}}=\text { total vertical stress. }
\end{aligned}
$$

- A thermal gradient of $18.4^{\circ} \mathrm{C} / \mathrm{km}$ was established for temperature data.

\section{References}

Bassinot, F.C., Labeyrie, L.D., Vincent, E., Quidelleur, X., Shackleton, N.J., and Lancelot, Y., 1994. The astronomical theory of climate and the age of the Brunhes-Matuyama magnetic reversal. Earth Planet. Sci. Lett., 126:91108. doi:10.1016/0012-821X(94)90244-5

Berggren, W.A., Hilgen, F.J., Langereis, C.G., Kent, D.V., Obradovich, J.D., Raffi, I., Raymo, M.E., and Shackleton, N.J., 1995. Late Neogene chronology: new perspectives in high-resolution stratigraphy. Geol. Soc. Am. Bull., 107:1272-1287. doi:10.1130/00167606(1995)107<1272:LNCNPI>2.3.CO;2

Cisowski, S.M., and Hall, F.R., 1997. An examination of the paleointensity record and geomagnetic excursions recorded in Leg 155 cores. In Flood, R.D., Piper, D.J.W., Klaus, A., and Peterson, L.C. (Eds.), Proc. ODP, Sci. Results, 155: College Station, TX (Ocean Drilling Program), 231-243.

Clark, H.C., and Kennett, J.P., 1973. Paleomagnetic excursions recorded in latest Pleistocene deep-sea sediments, Gulf of Mexico. Earth Planet. Sci. Lett., 19(2):267-274. doi:10.1016/0012-821X(73)90127-1

Flood, R.D., Piper, D.J.W., Klaus, A., et al., 1995. Proc. ODP, Init. Repts., 155: College Station, TX (Ocean Drilling Program).

Freed, W.K., and Healy, N., 1974. Excursions of the Pleistocene geomagnetic field recorded in Gulf of Mexico sediments. Earth Planet. Sci. Lett., 24:99-104. doi:10.1016/0012-821X(74)90013-2

Froelich, P.N., Klinkhammer, G.P., Bender, M.L., Luedtke, N.A., Heath, G.R., Cullen, D., Dauphin, P., Hammond,
D., Hartman, B., and Maynard, V., 1979. Early oxidation of organic matter in pelagic sediments of the eastern equatorial Atlantic: suboxic diagenesis. Geochim. Cosmochim. Acta, 43(7):1075-1090. doi:10.1016/00167037(79)90095-4

Hine, H., and Weaver, P.P.E., 1998. Quaternary. In Bown, P.R. (Ed.), Calcareous Nannofossil Biostratigraphy: Dordrecht, The Netherlands (Kluwer Academic Publ.), 266283.

Jasper, J.P., and Gagosian, R.B., 1990. The sources and deposition of organic matter in the Late Quaternary Pigmy Basin, Gulf of Mexico. Geochim. Cosmochim. Acta, 54:1117-1132. doi:10.1016/0016-7037(90)90443-O

Kennett, J.P., and Huddlestun, P., 1972. Late Pleistocene paleoclimatology, foraminiferal biostratigraphy, and tephrochronology, western Gulf of Mexico. Quat. Res., 2:38-69. doi:10.1016/0033-5894(72)90004-X

Kvenvolden, K.A., and Barnard, L.A., 1983. Gas hydrates of the Blake Outer Ridge, Site 533, Deep Sea Drilling Project Leg 76. In Sheridan, R.E., Gradstein, F.M., et al., Init. Repts. DSDP, 76: Washington (U.S. Govt. Printing Office), 353-365.

Mallarino, G., Droxler, A.W., Beaubouef, R.T., Abreu, V., and Laberye, L., in press. Sea level influence on the nature and timing of a mini-basin sedimentary fill (northwestern slope of the Gulf of Mexico). AAPG Bull.

Piper, D.J.W., and Deptuck, M., 1997. Fined-grained turbidites of the Amazon Fan: facies characterization and interpretation. In Flood, R.D., Piper, D.J.W., Klaus, A., and Peterson, L.C. (Eds.), Proc. ODP, Sci. Results, 155: College Station, TX (Ocean Drilling Program), 79-108.

Pirmez, C., and Isram, J., 2003. Reconstruction of turbidity currents in Amazon Channel. Mar. Petrol. Geol., 20(68):823-849. doi:10.1016/j.marpetgeo.2003.03.005

Rider, M., 1996. The Geological Interpretation of Well Logs (2nd ed.): Caithness (Whittles Publishing).

Stupavsky, M., and Gravenor, C.P., 1984. Paleomagnetic dating of Quaternary sediments: a review. In Mahaney, W.C. (Ed.), Quaternary Dating Methods: Amsterdam (Elsevier).

van Hinsbergen, D.J.J., Kouwenhoven, T.J., and van der Zwaan, G.J., 2005. Paleobathymetry in the backstripping procedure: correction for oxygenation effects on depth estimates. Palaeogeogr., Palaeoclimatol., Palaeoecol., 221(3-4):245-265. doi:10.1016/j.palaeo.2005.02.013

von Dobeneck, T., and Schmieder, F., 1999. Using rock magnetic proxy records for orbital tuning and extended time series analysis into the super- and sub-Milankovitch bands. In Fischer, G., and Wefer, G. (Eds.), Use of Proxies in Paleoceanography: Examples from the South Atlantic: Heidelberg (Springer-Verlag), 601-633.

Winker, C.D., and Shipp, R.C., 2002. Sequence stratigraphic framework for prediction of shallow water flow in the greater Mars-Ursa area, Mississippi Canyon area, Gulf of Mexico continental slope [22nd Annual GCSSEPM Foundation Bob F. Perkins Research Conference, Houston, TX, 8-11 December, 2002]. (Abstract)

Publication: 8 July 2006 MS 308-108 
Figure F1. Seismic strip chart, Site U1324. TD = total depth.

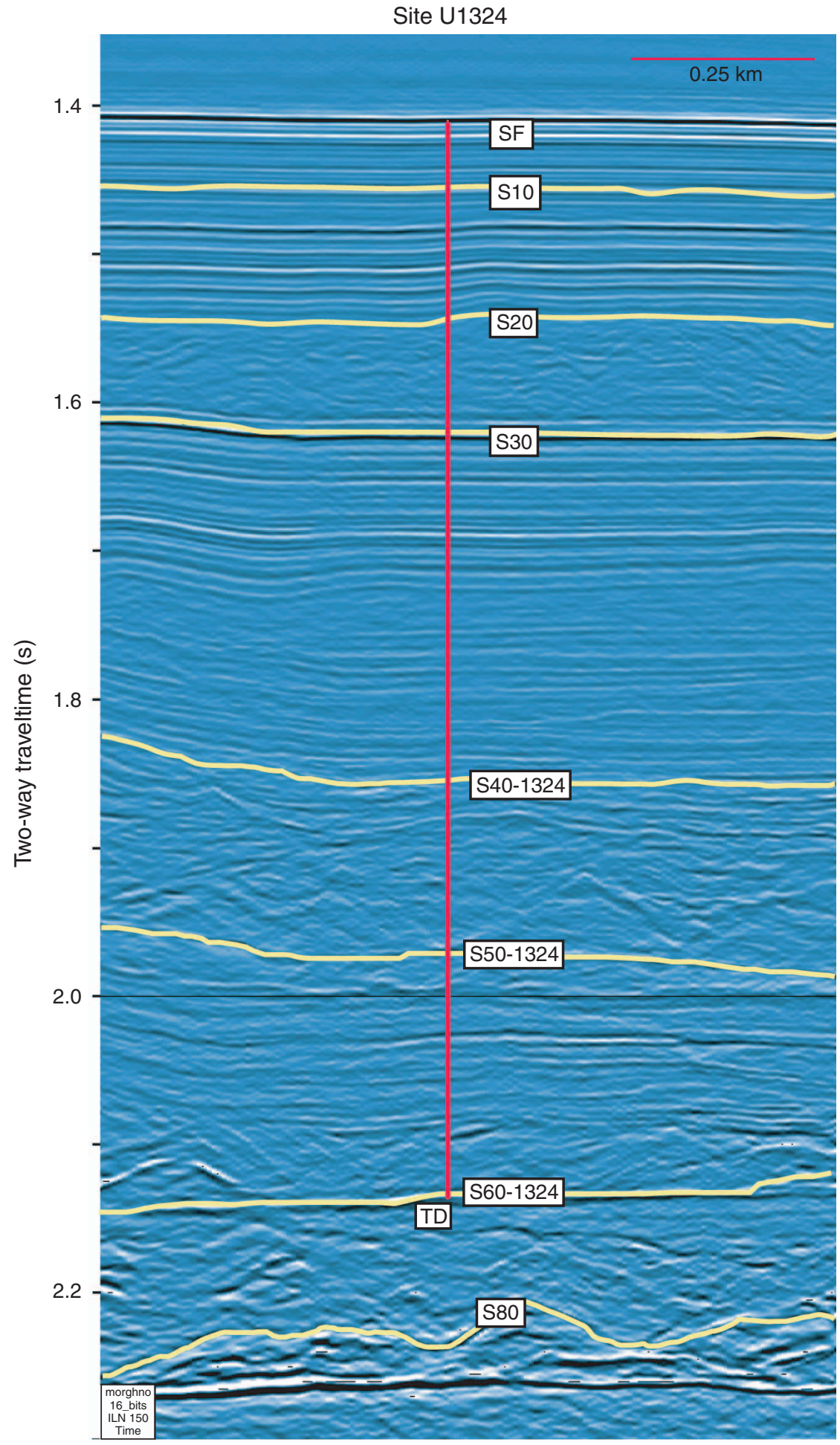


Figure F2. Lithostratigraphic summary with gamma ray (GR) and resistivity (RES) logs (LWD/MWD). Seismic panel was split at the location of Hole U1324B at Trace 72. Seismic data are approximately zero phase with peaks (black) and troughs (white) and are plotted in depth using the check shot generated from wireline logging in Hole U1324A. Key seismic reflectors are yellow/labeled.

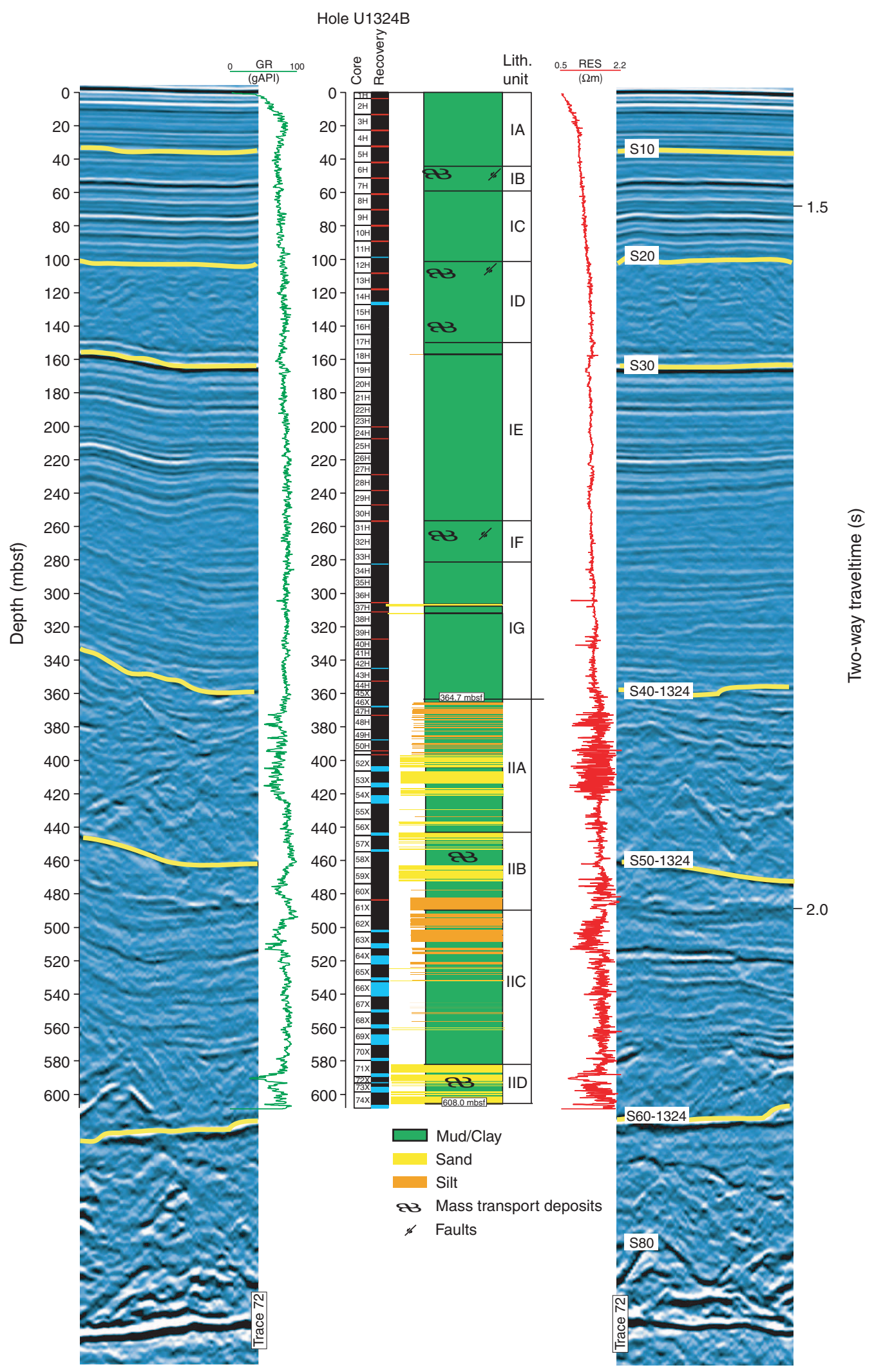


Figure F3. Lithostratigraphic Subunit IA. A. Greenish brown to reddish brown clay interpreted to be hemipelagic deposits (Section 308-U1324B-1H-1; DIS image). B. Light greenish gray near the top and greenish gray at the bottom (interval 308-U1324B-1H-1, 18-42 cm). (Continued on next page.)

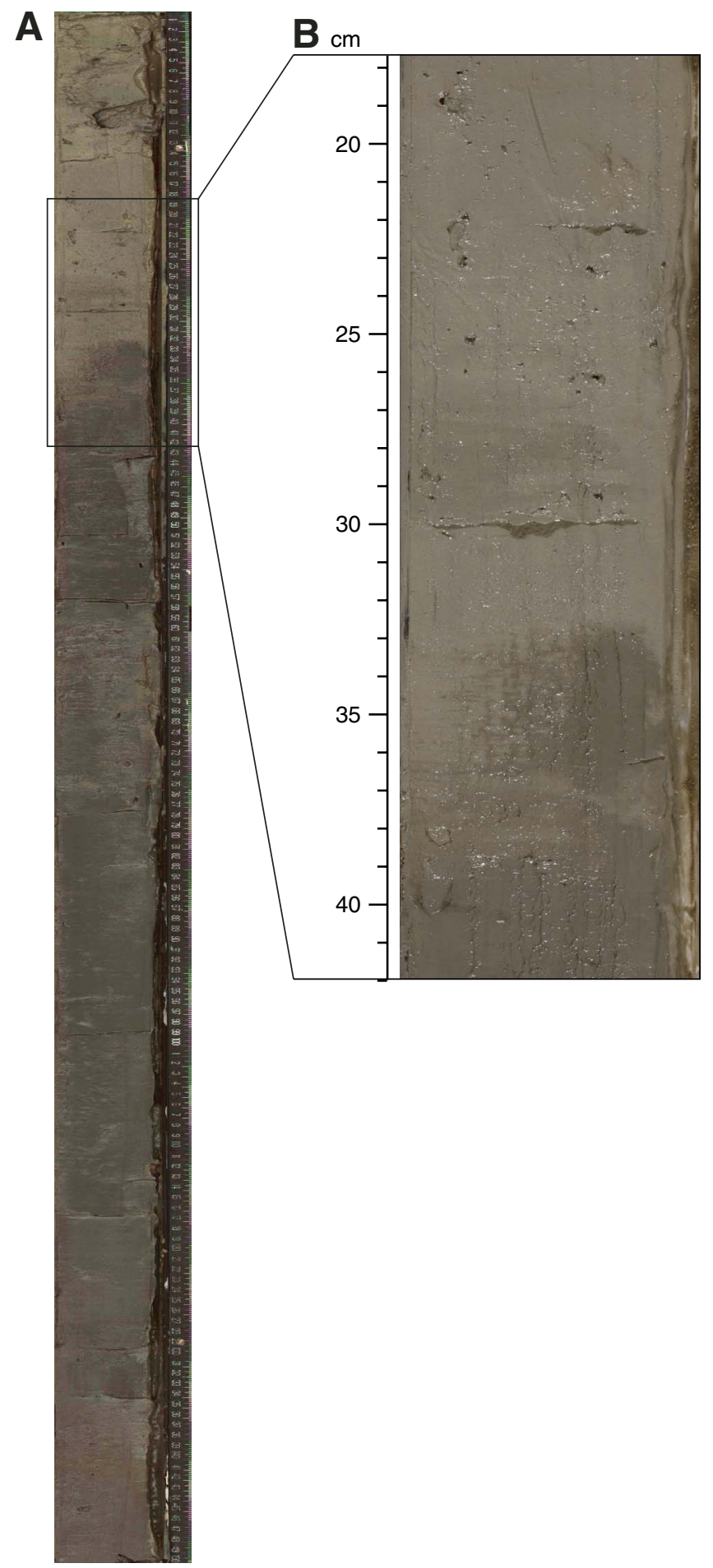


Figure F3 (continued). C. Globigerina falconensis in a foraminifer-rich clay (Sample 308-U1324B-1H-1, $20 \mathrm{~cm}$ ). D. Foraminifer-rich clay with Globigerina quinqueloba in Subunit IA (Sample 308-U1324B-1H-1, $20 \mathrm{~cm}$ ). E. Foraminifer-rich clay with Globorotalia quinqueloba, Globorotalia siphonifera, and Bolivina spissa in Subunit IA (Sample 308-U1324B-1H-1, 20 cm). F. Clay with sponge spicules in Subunit IA (Sample 308-U1324B-4H-4, $99.5 \mathrm{~cm})$.

C

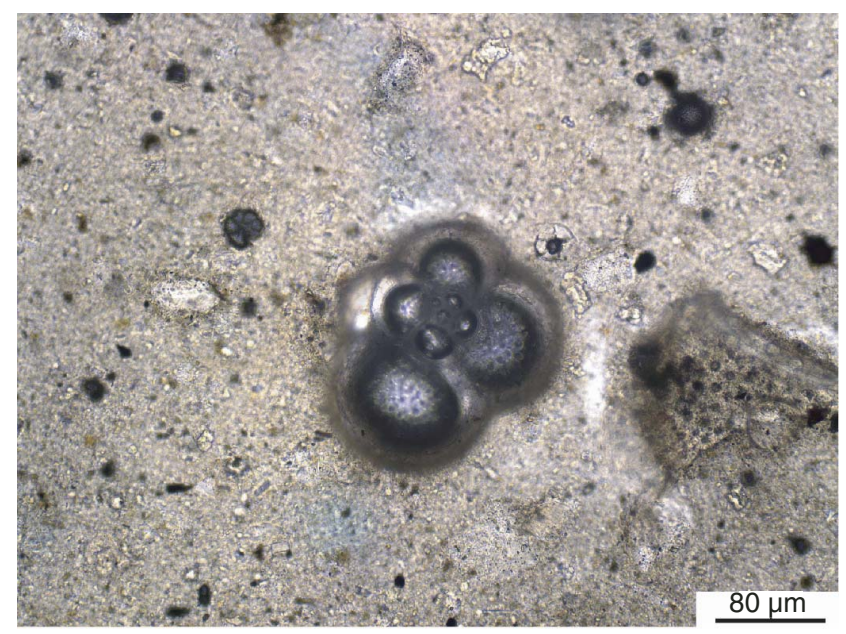

\section{E}

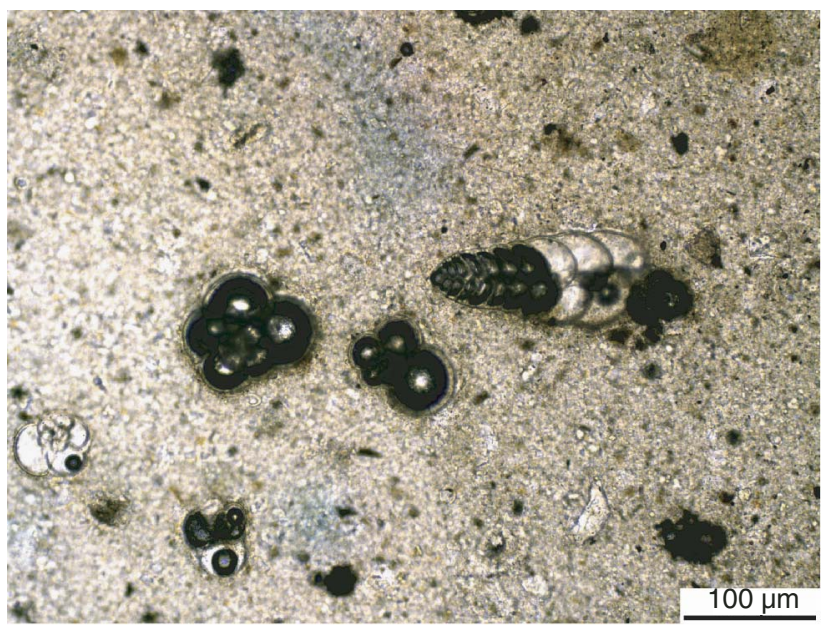

D

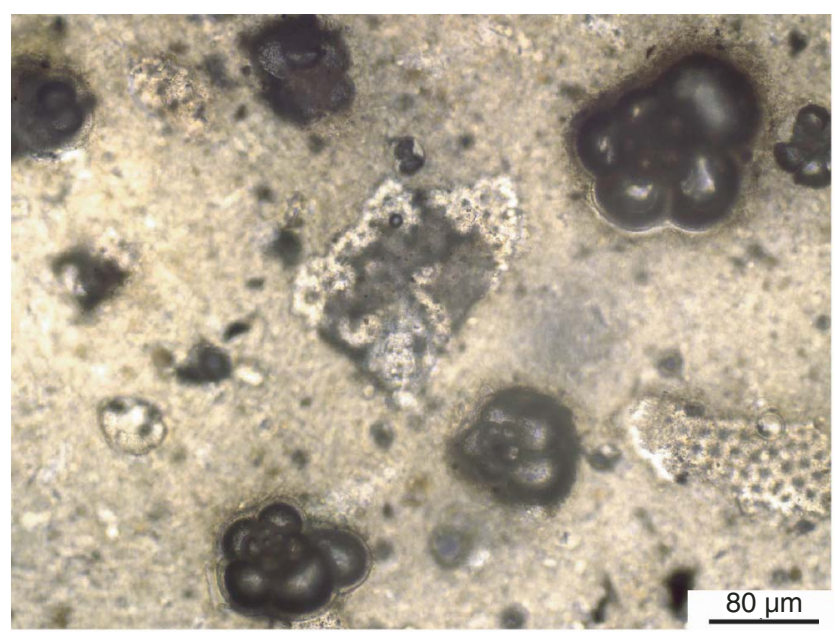

F

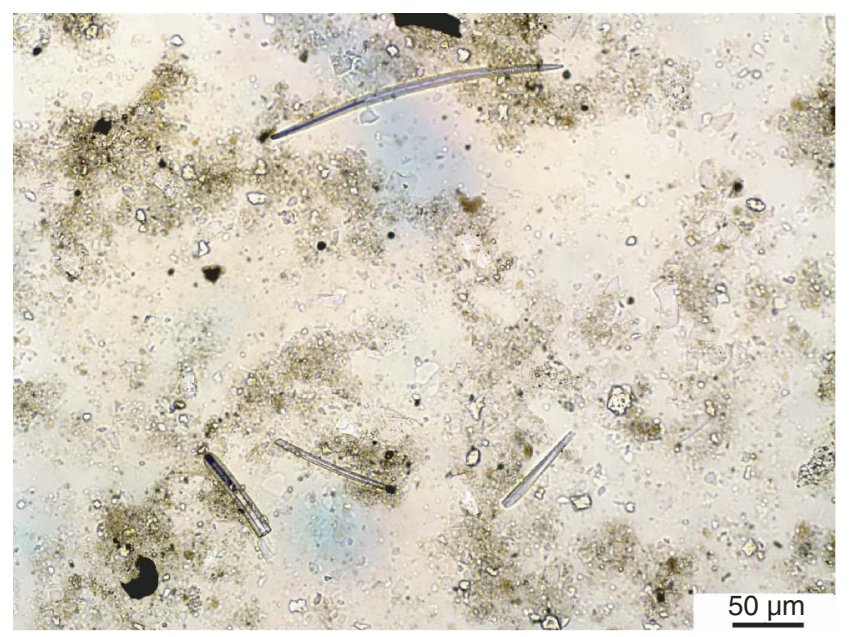


Figure F4. Gradation from dark gray to greenish gray and light gray clay in lithostratigraphic Subunit IB. A. Fault strike is $124^{\circ}$ (interval $308-\mathrm{U} 1324 \mathrm{~B}-6 \mathrm{H}-2,41-64 \mathrm{~cm}$ ). B. Fault strike is $150^{\circ}$ with a dip of $60^{\circ} \mathrm{NW}$ (interval 308-U1324B-6H-5, 93-117 cm).
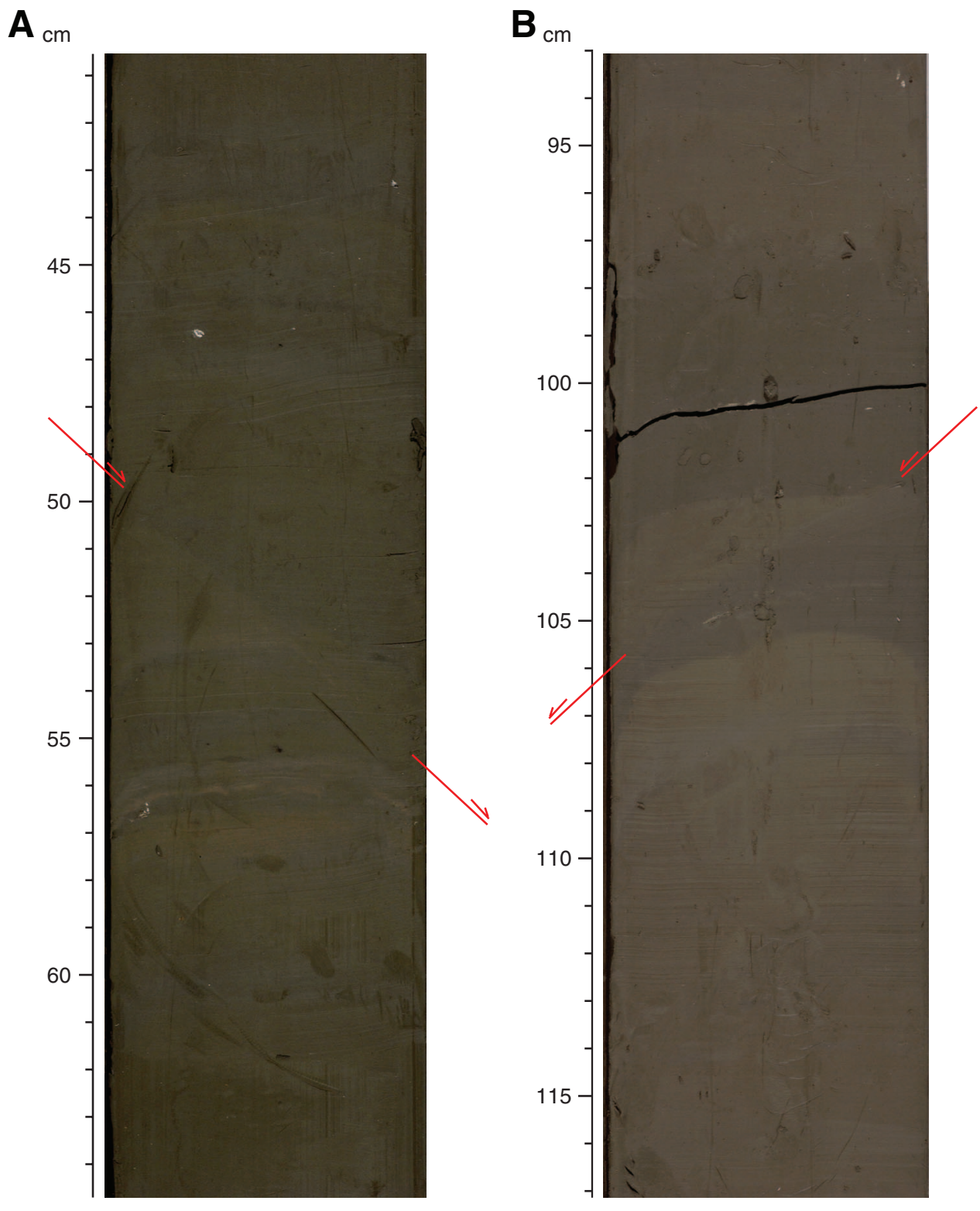
Figure F5. Alternation of greenish gray clay bands and light/dark clay laminae and thin beds in lithostratigraphic Subunit IC. A. Silt occurs as disrupted laminae $(58 \mathrm{~cm}$ ) and 44.5, 49.5, and $52 \mathrm{~cm}$ filled burrows (interval 308-U1324B-8H-4, 28-63 cm). B. Color-banded clay in interval 308-U1324B-10H-2, 72-108 cm.
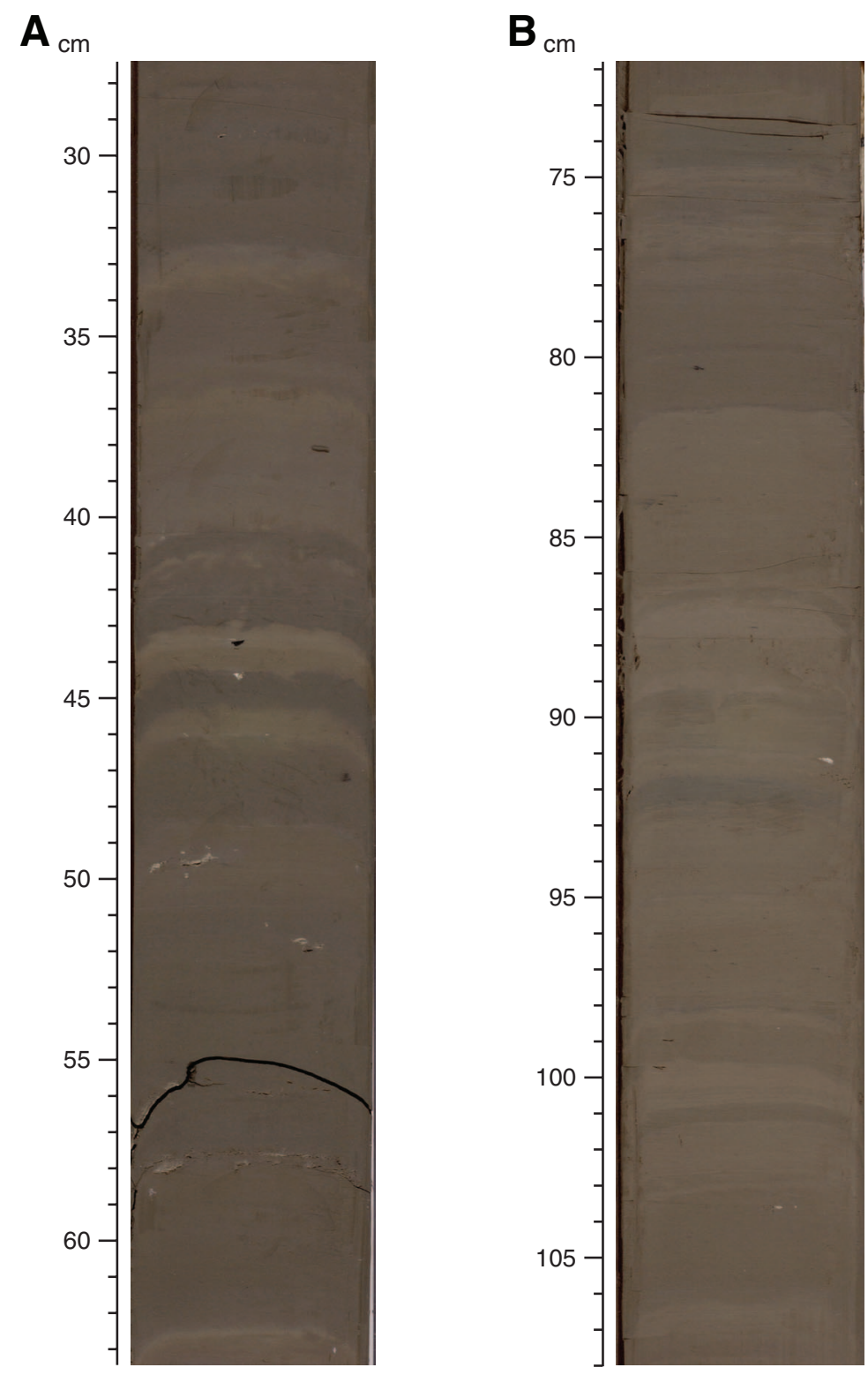
Figure F6. Couplets of greenish gray and brownish gray dipping beds in lithostratigraphic Subunit ID. A, B. Faults (intervals 308-U1324B-15H-2, 29-64 cm, and 15H-2, 8-32 cm). C. Dipping beds (interval 308U1324B-13H-2, 98-134 cm).

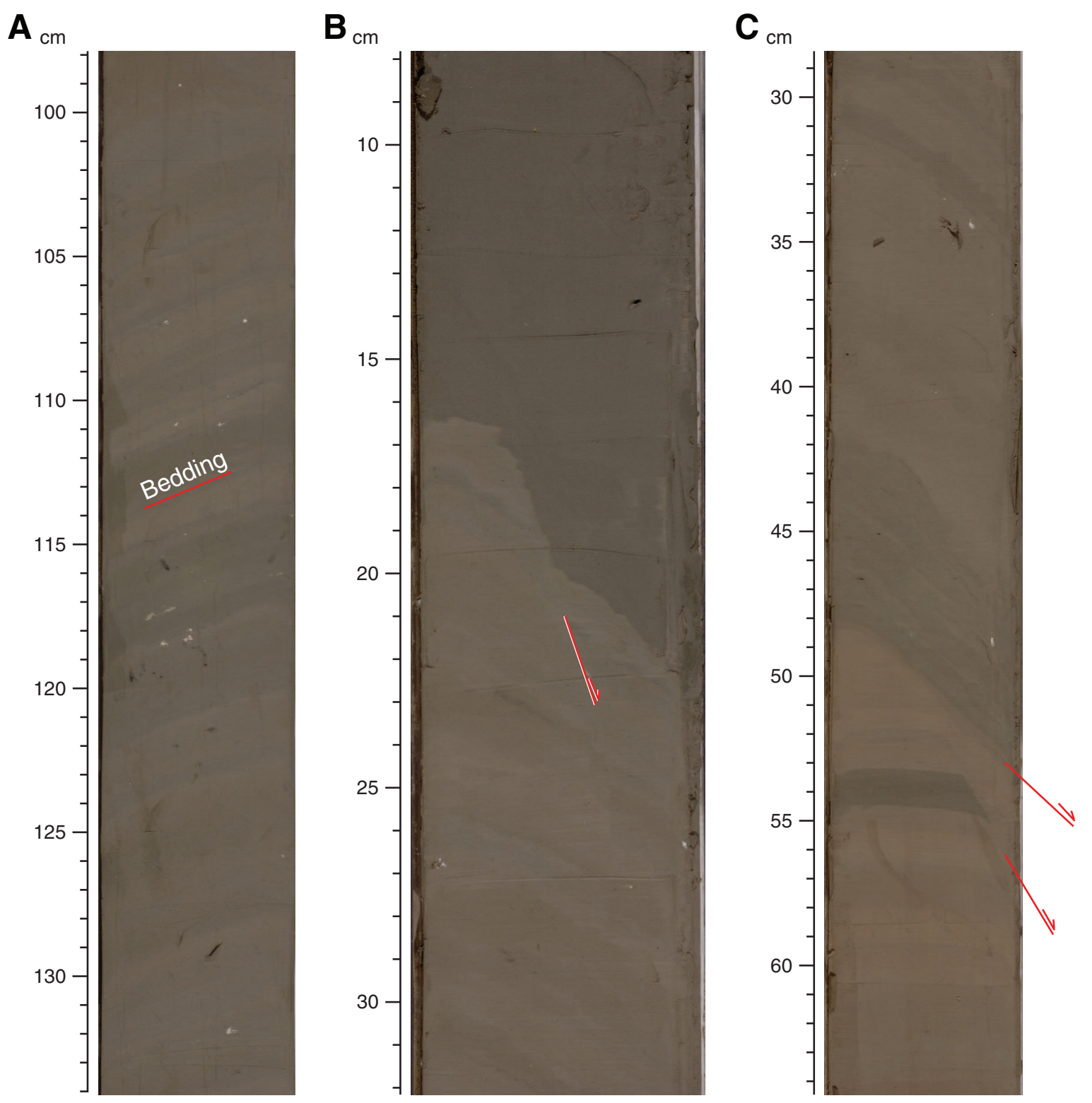


Figure F7. Fine-scale color banding in lithostratigraphic Subunit IE. A. Dark gray and brown (interval 308U1324B-17H-4, 26-61 cm). B. Color changes at seismic Reflector S30 to reddish brown (308-U1324B-19H-3, 58-92 cm). C. Alternation of dark greenish gray and brownish clay layers (interval 308-U1324B-21H-4, 25-60 $\mathrm{cm})$. D. Greenish brown clay, a reddish brown clay band at $60-74 \mathrm{~cm}$ with gradational color change, and mottled black clay (interval 308-U1324B-28H-2, 51-90 cm).

$\mathbf{A}_{\mathrm{cm}}$

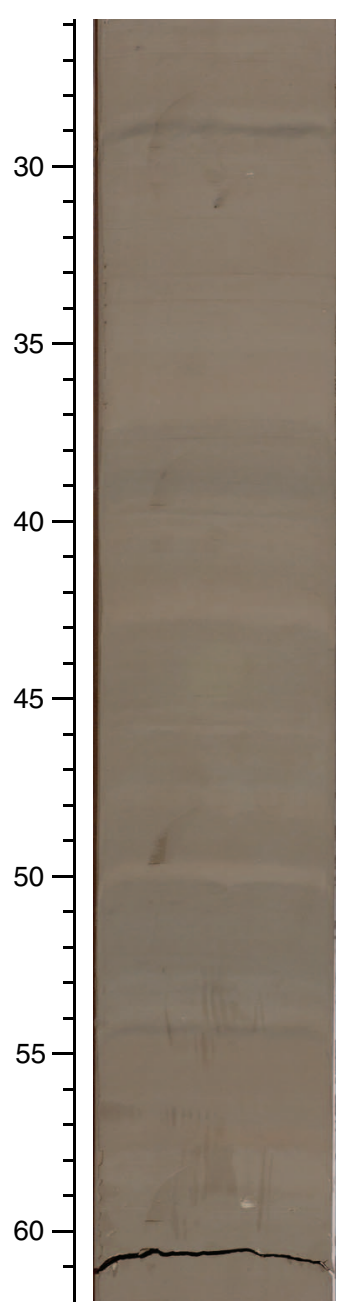

B $\mathrm{S} 30 \mathrm{~cm}$

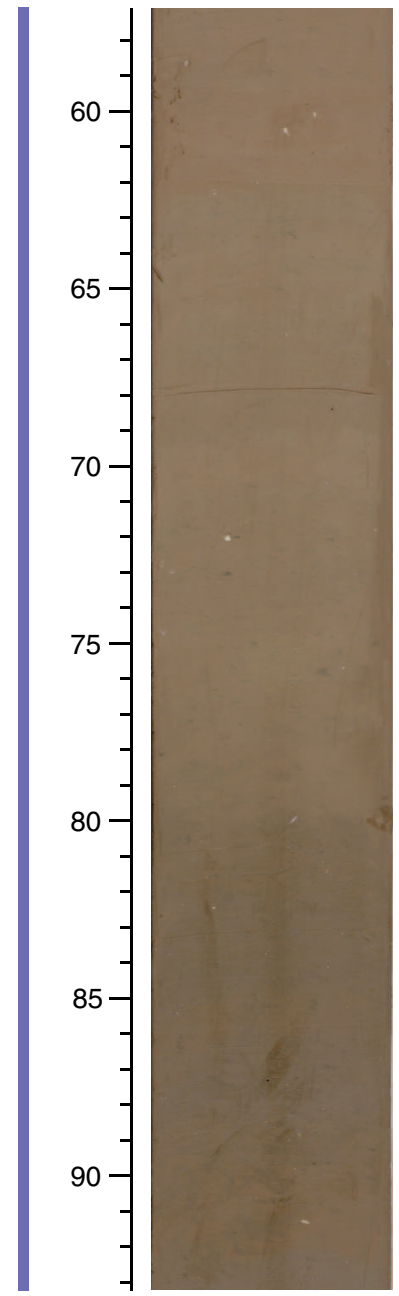

C $\mathrm{cm}$

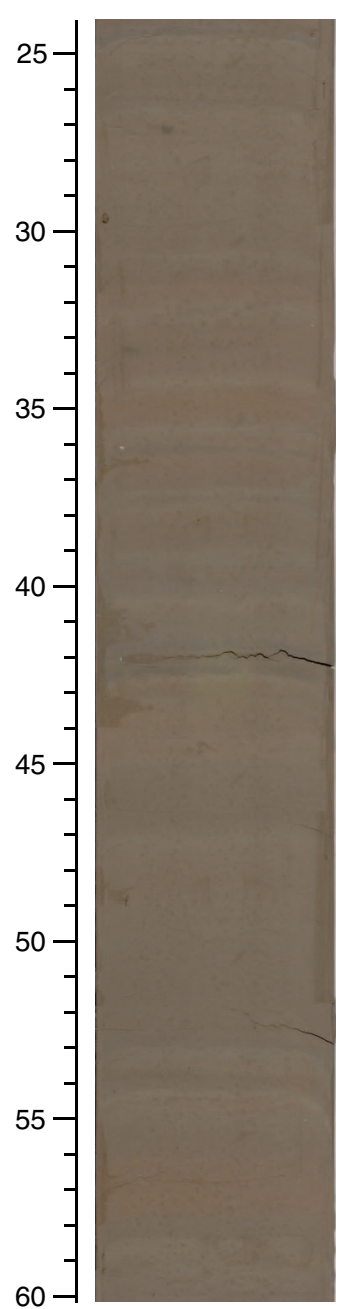

D ${ }_{\mathrm{cm}}$

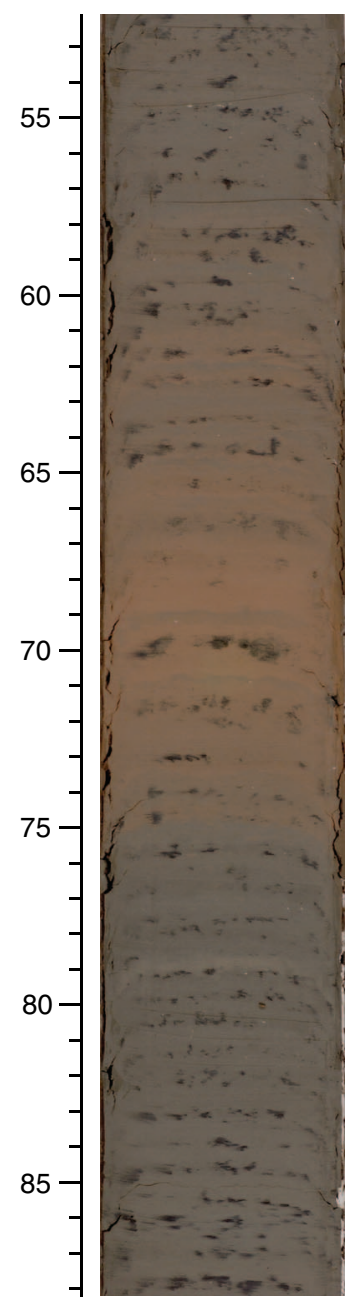


Figure F8. Green and brownish green clay alternating with black laminae in lithostratigraphic Subunit IF. A. Composite DIS image of Sections 308-U1324B-32H-1 through 32H-3, showing inclined beds strike N120E (upper), N140E (middle), and N125E (bottom) with a dip of $50^{\circ}$. B. Composite DIS image of Sections 308U1324B-34H-2 through 34H-3, showing inclined beds that strike N150E (upper) to N40E (lower) with a dip of $90^{\circ}$ (horizontal). Note that the composite DIS images do not display correct angles because it is vertically compressed. See Table $\mathbf{T} 5$ for measurements.

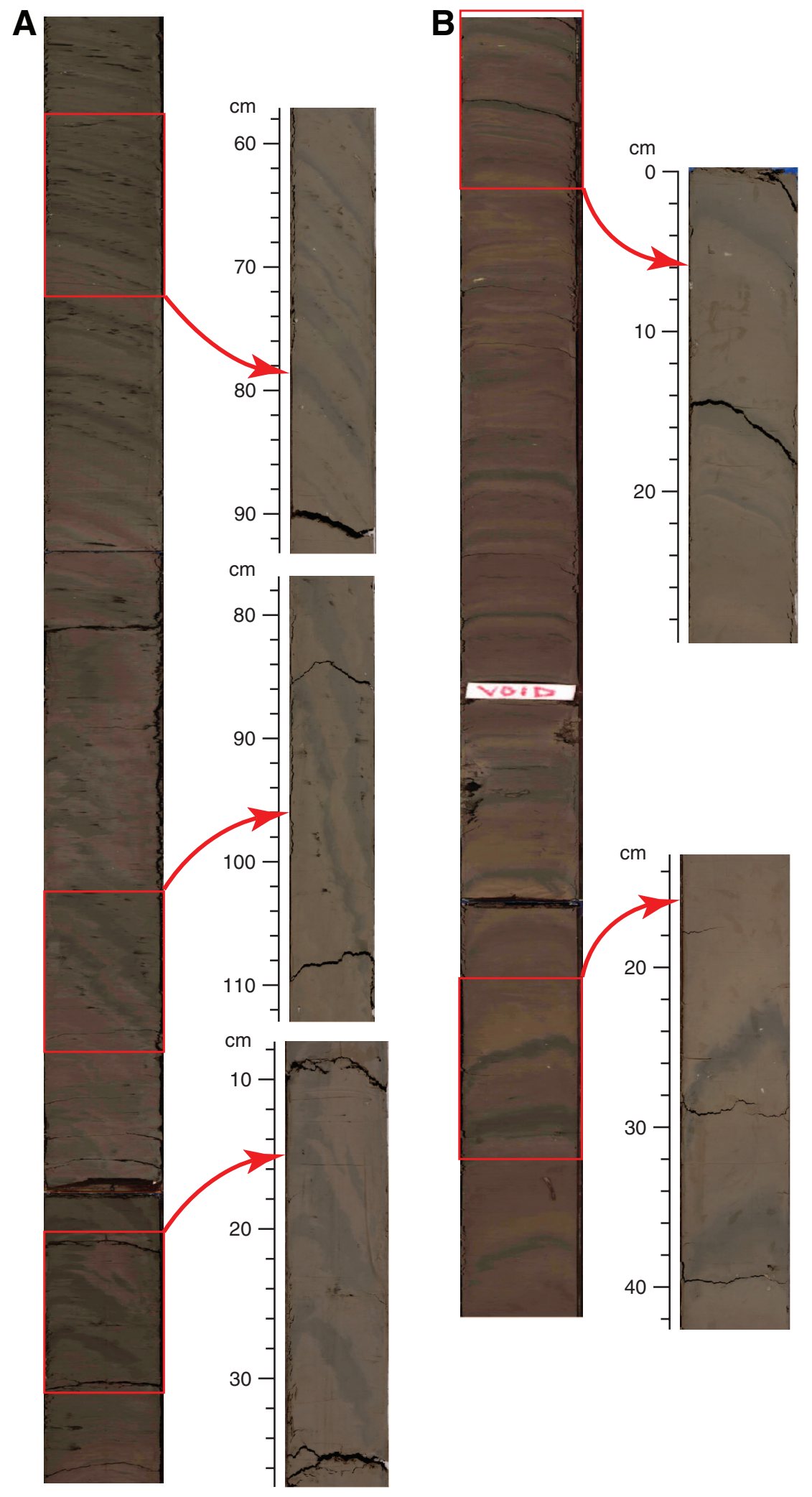


Figure F9. Lithostratigraphic Subunit IG. A. Lower medium sand (top), which could have resulted from flowin from a thinner layer, and greenish gray clay with dark gray laminae (base) (Section 308-U1324B-37H-1; DIS image). B. Couplets of dark gray and lighter gray/brown clay with reddish bands with lighter gray clay and mottling throughout (Section 308-U1324B-40H-2; DIS image). C. Laminated silt bed with sharp base and top at 53-58 cm (interval 308-U1324B-40H-2, 40-76 cm). D. Lamination of greenish gray and reddish brown clay (interval 308-U1324B-44H-1, 68-103 cm). Note that DIS images do not reproduce exact sediment color.

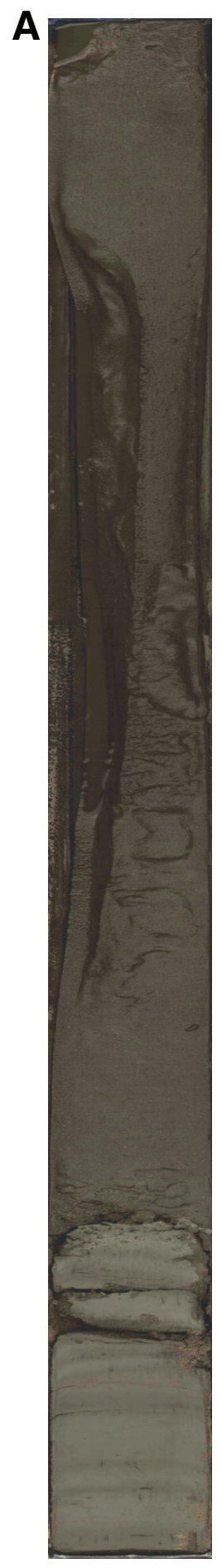

B

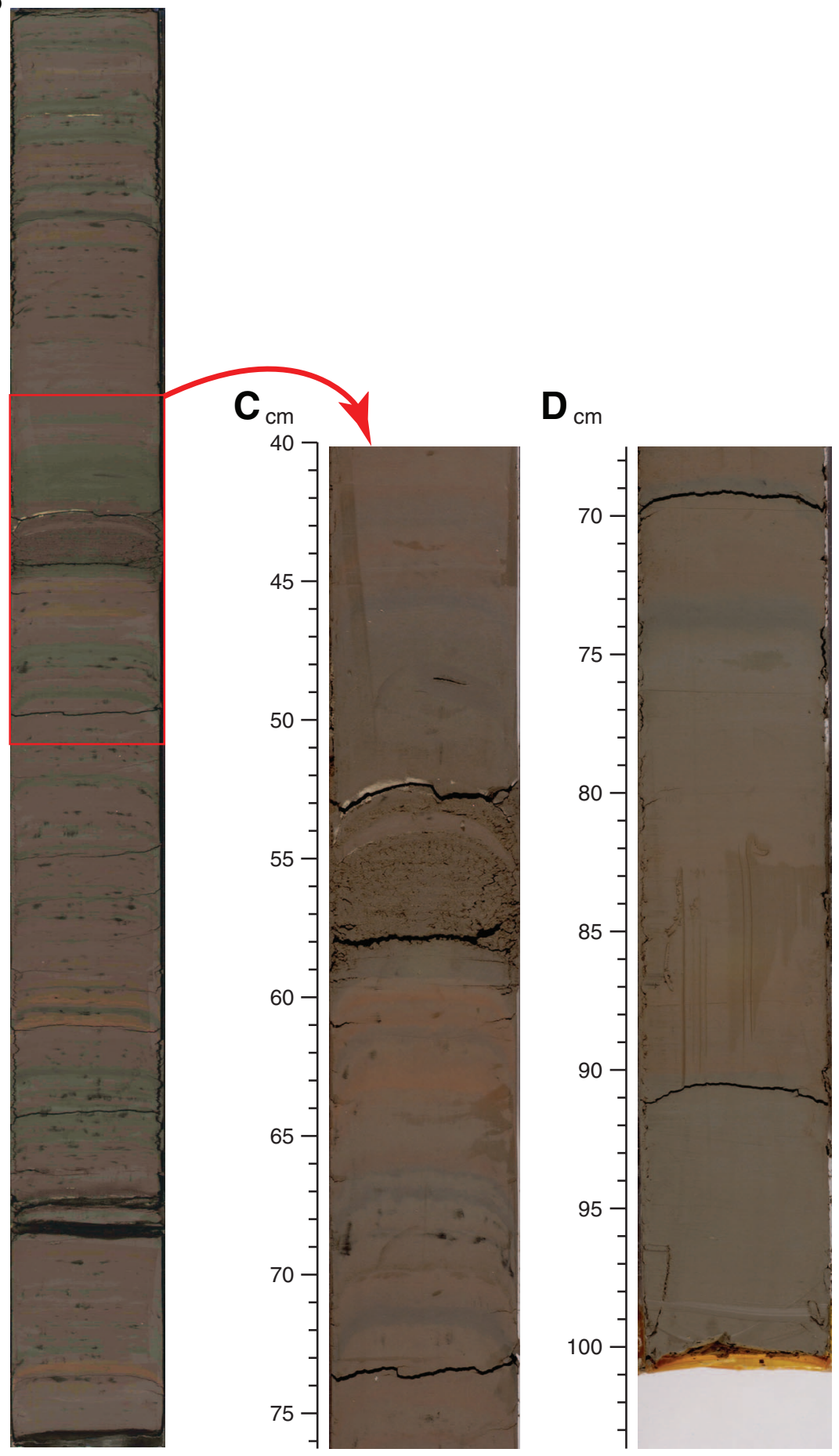


Figure F10. Lithostratigraphic Subunit IIA. A. Dark greenish gray and brown mud and silt as fining-upward beds with couplets of silt and mud (Core 308-U1324B-46X). B. Laminated silt bed interpreted as a distal turbidite at 109-132 cm (interval 308-U1324B-46X-2, 102-138 cm). C. Photographic detail of silt (Core 308U1324B-50X). D. Interbedded clay and silt in gray and medium brown clay (interval 308-U1324B-50X-2, 71$106 \mathrm{~cm}$; DIS image). Note that DIS images do not reproduce exact sediment color.

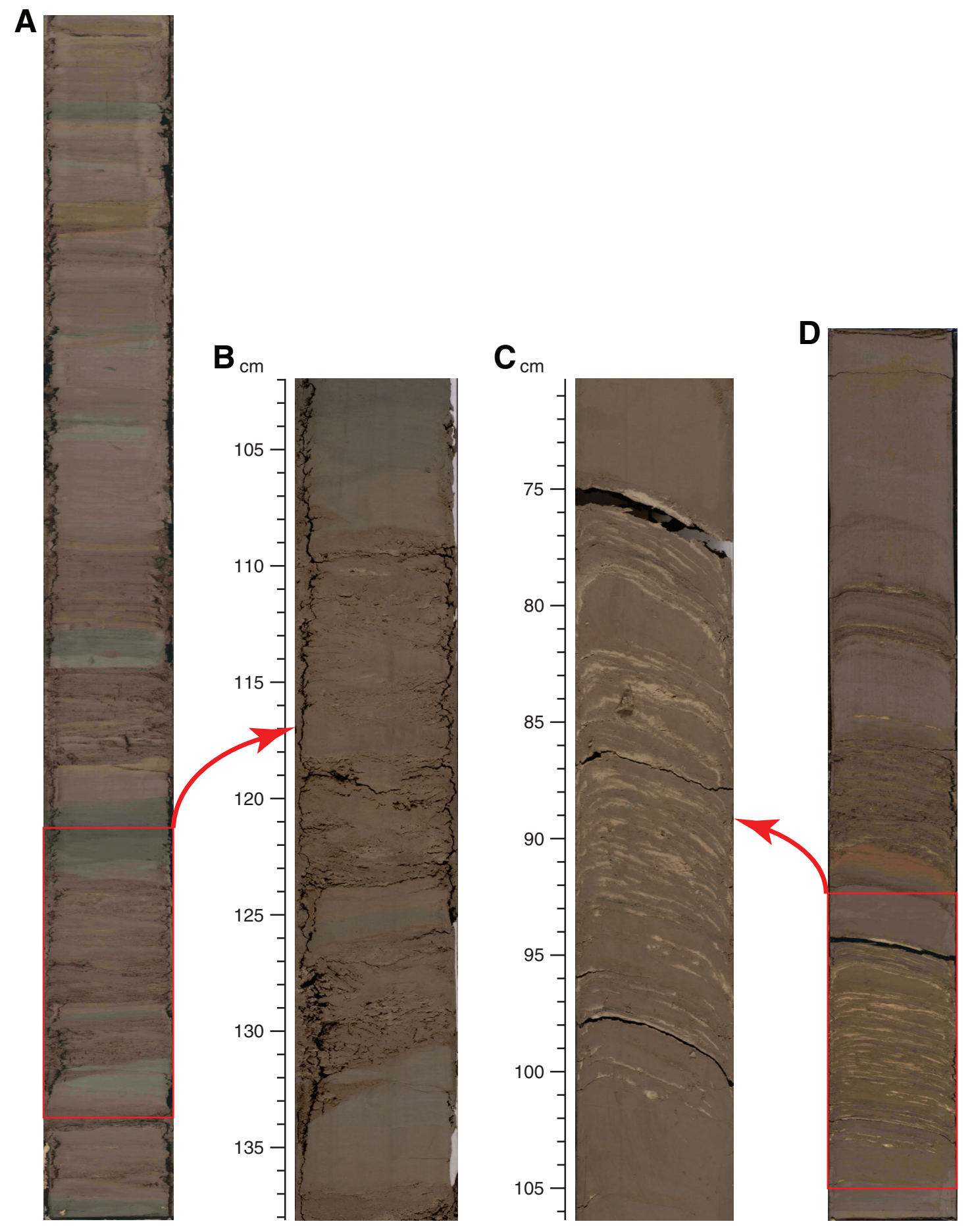


Figure F11. Mass transport deposits showing biscuits by drilling disturbance and folds in all sections of lithostratigraphic Subunit IIB. A, B. Interbedding of silty sand and gray and brownish clay (intervals 308-U1324B$57 \mathrm{X}-1,35-75 \mathrm{~cm}$, and $57 \mathrm{X}-2,118-150 \mathrm{~cm})$. C, D. Greenish gray mud, showing contorted bedding and interbedded silt and sand (intervals 308-U1324B-59X-2, 48-83 cm, and 59X-7, 98-132 cm).

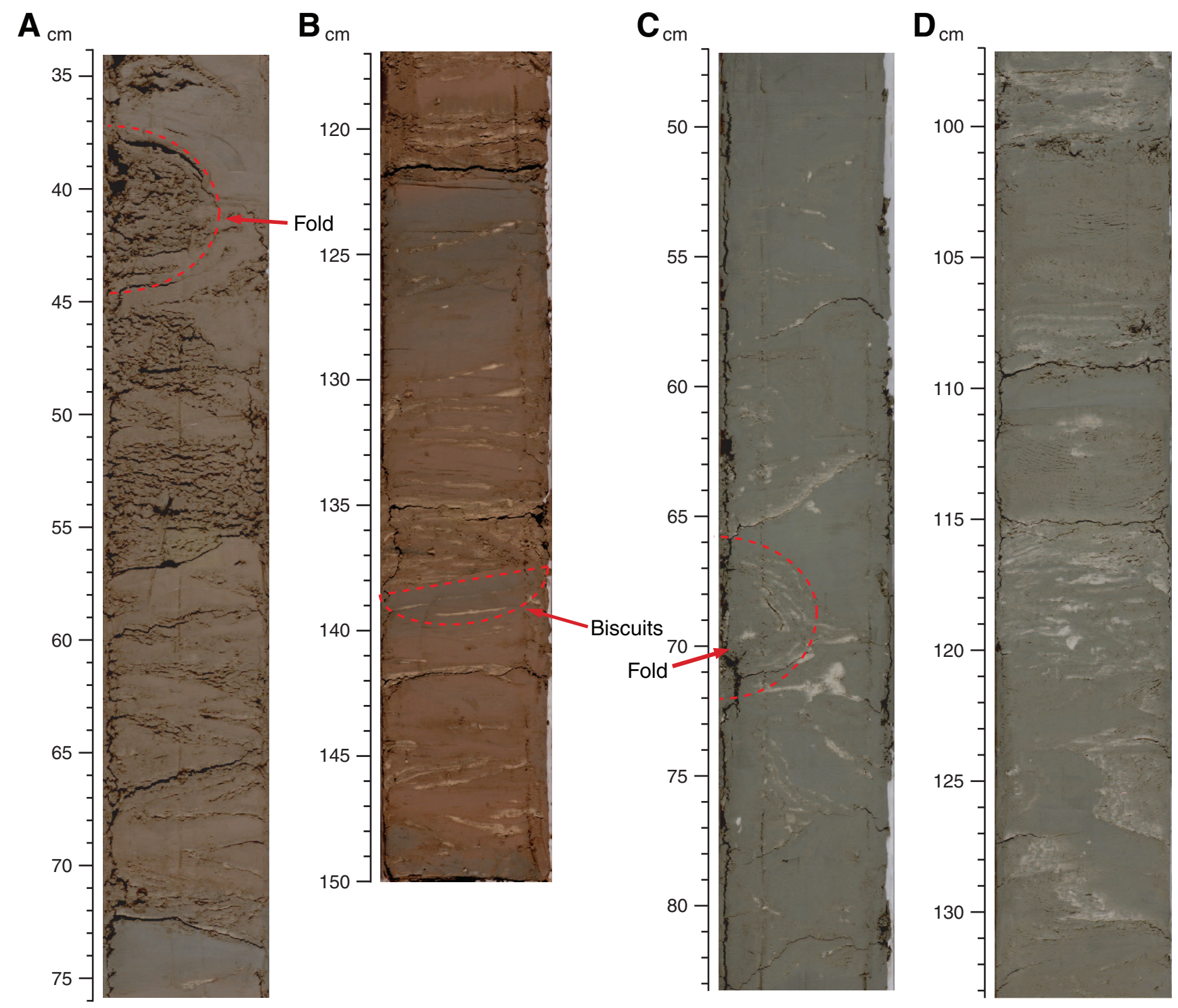


Figure F12. Lithostratigraphic Subunit IIC. A. Green and reddish brown clay interbedded with silt beds (Core 308-U1324B-62X; DIS image). B. Sequence consisting of brown silt with a sharp base at $74 \mathrm{~cm}$, fining upward to greenish mud with laminae and reddish mud at the top (interval 308-U1324B-62X-5, $44-80 \mathrm{~cm}$ ). C. Interbeds of greenish gray mud and silt (Core 308-U1324B-64X; DIS image). D. Normally graded silt beds and laminae at 122-128 cm (interval 308-U1324B-64X-4, 114-137 cm). E. Laminated silty sand bed with quartz and calcite in Subunit IIC (Sample 308-U1324B-63X-5, $82 \mathrm{~cm}$ ).

A

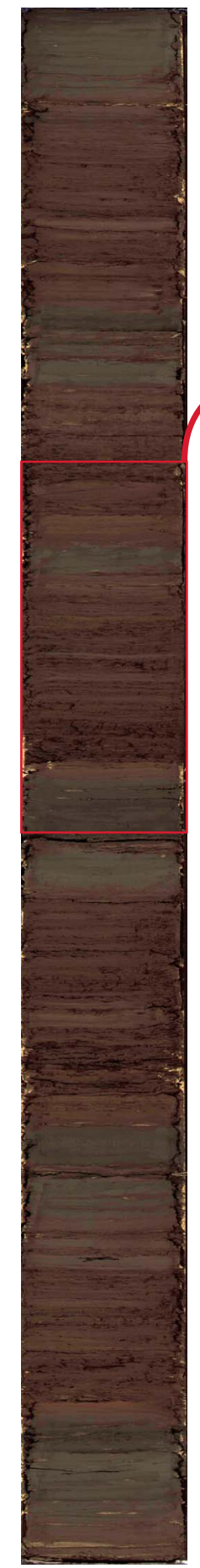

$\mathbf{B}_{\mathrm{cm}}$

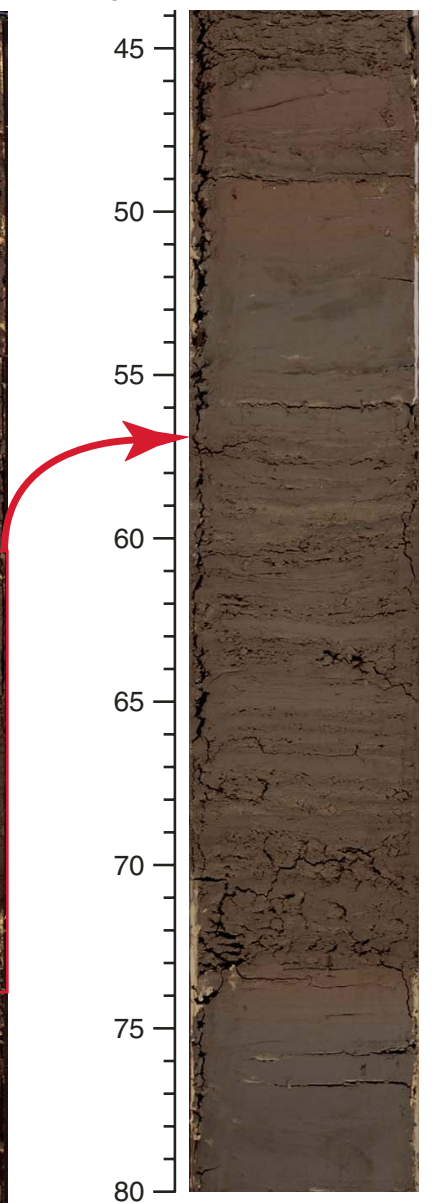

$\mathbf{C}_{\mathrm{cm}}$

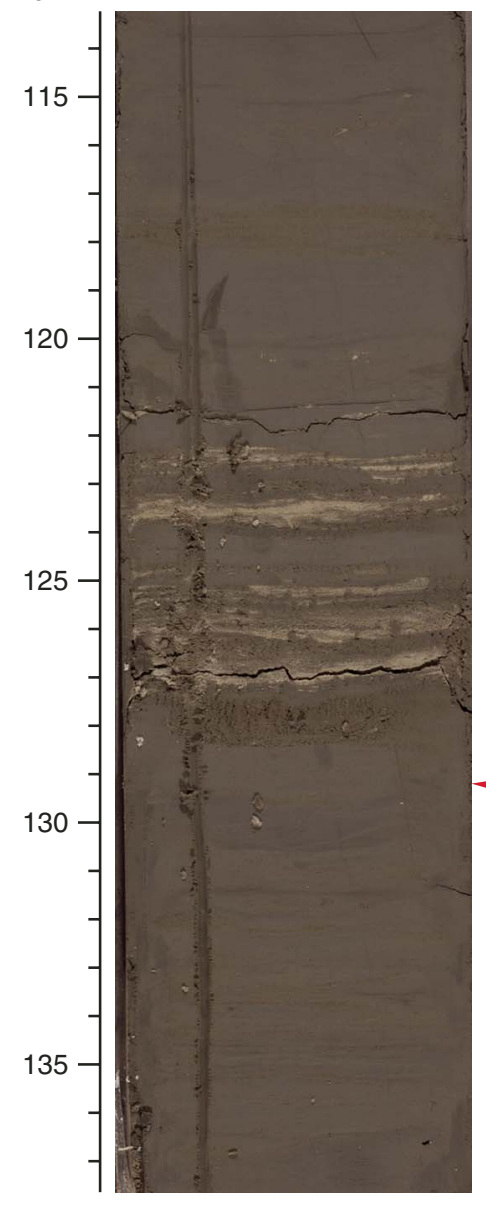

E

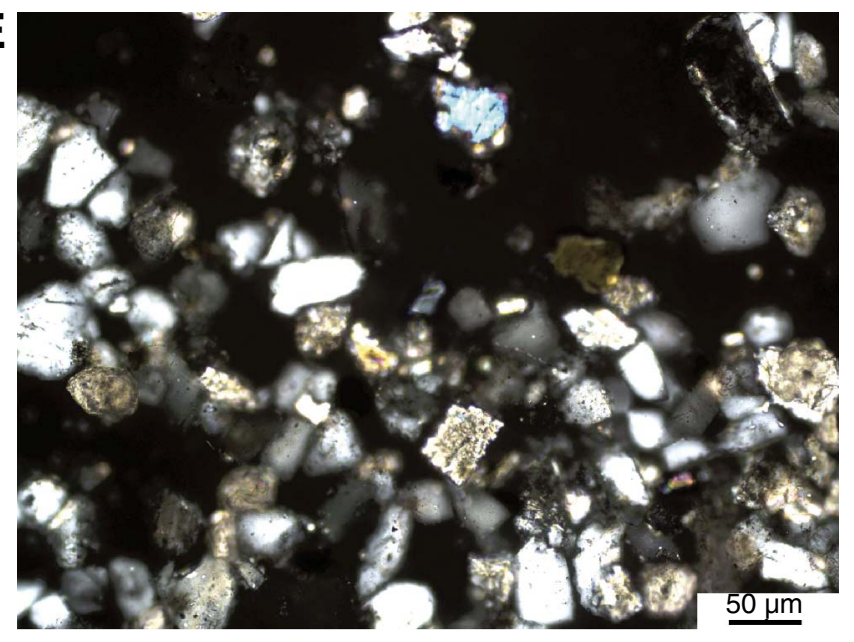

D
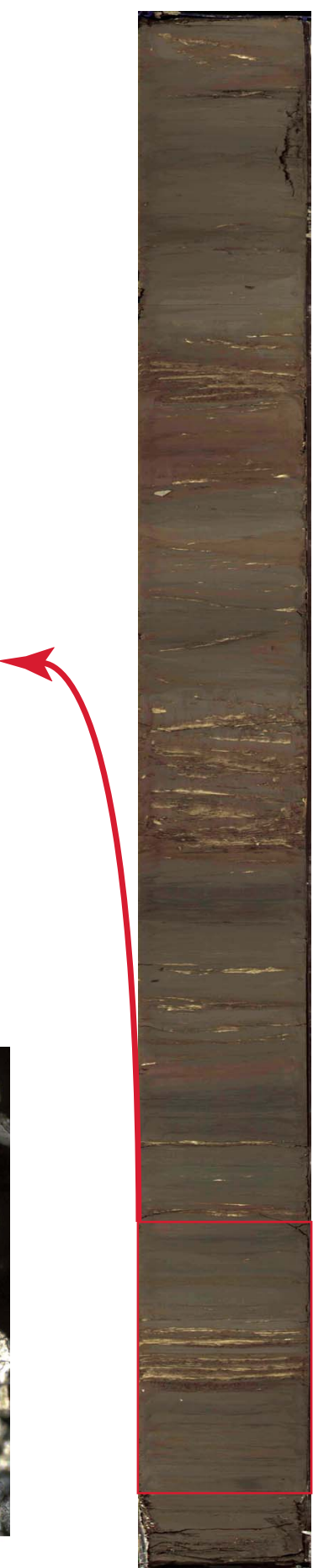
Figure F13. Mass transport deposits characterized by greenish gray contorted mud bedding and sand as irregular lenses and laminae in lithostratigraphic Subunit IID. A, B. Intervals 308-U1324B-73X-1, 38-67 cm, and 73X-1, 118-140 cm. C, D. Intervals 308-U1324B-74X-1, 88-120 cm, and 74X-2, 96-132 cm. XCB biscuiting is particularly pronounced in these images.

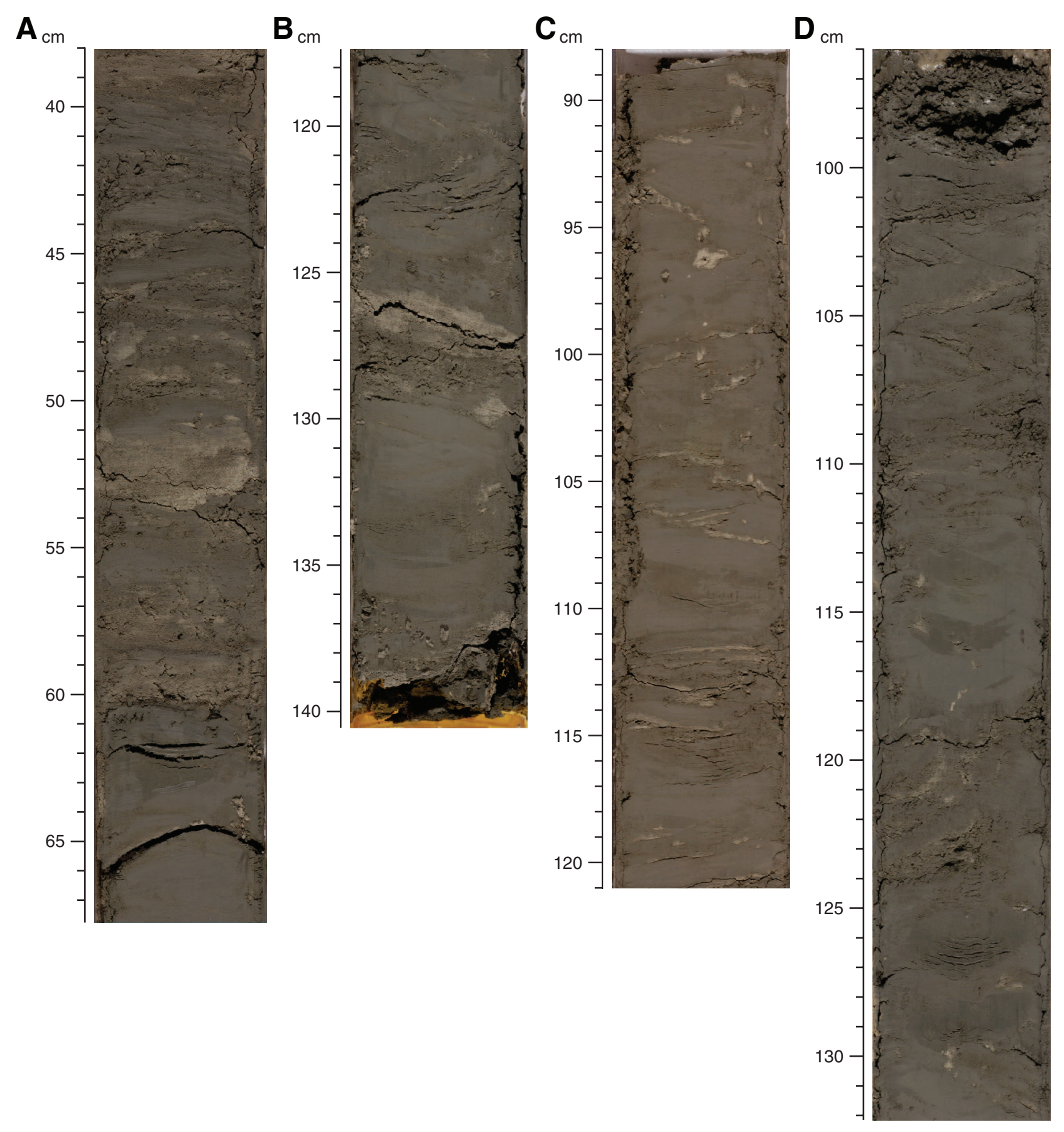


Figure F14. Summary of smear slide analysis showing dominant and minor lithologic components.

Hole U1324B smear slides

Percent of sample (\%)

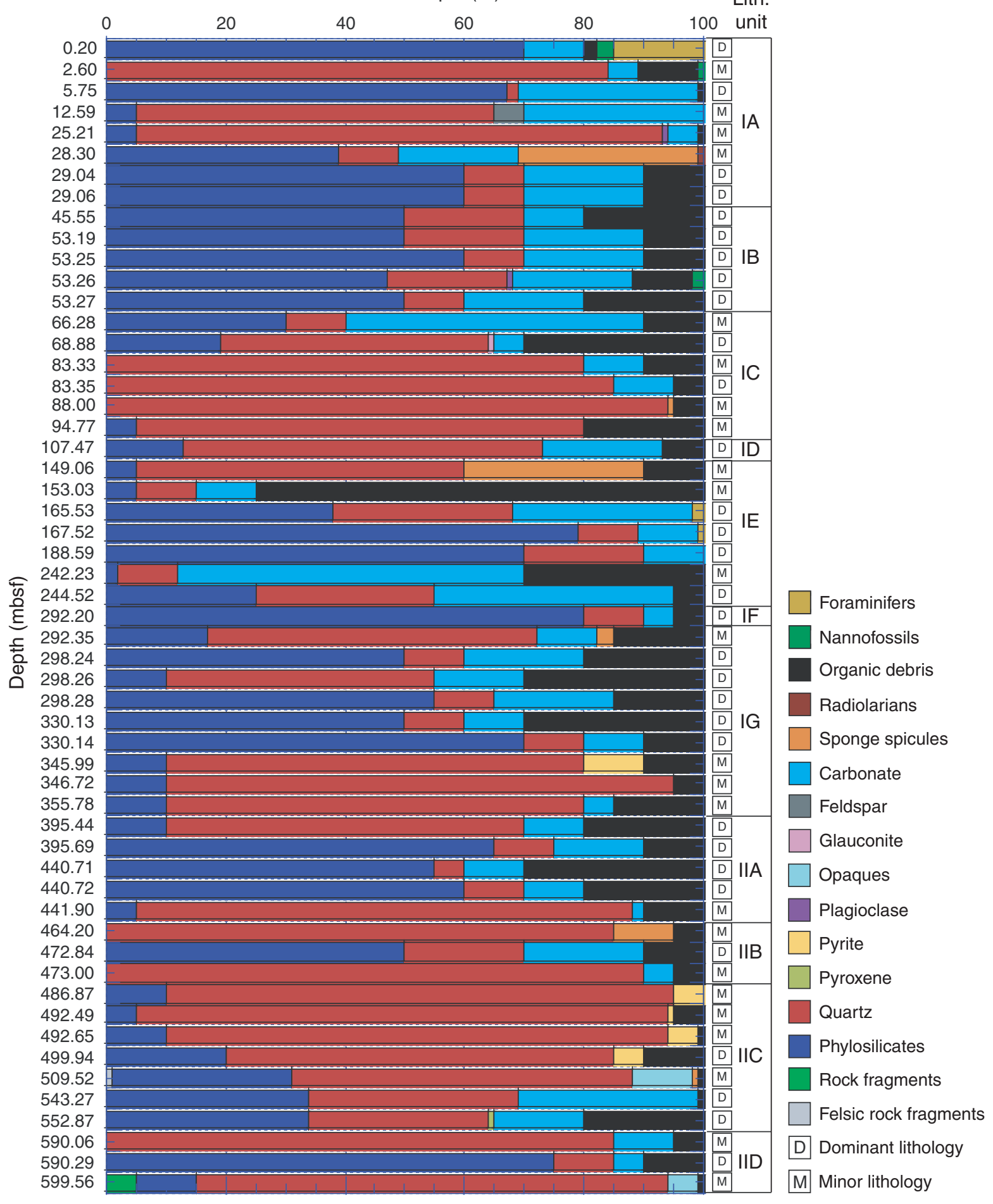


Figure F15. Results of the XRD analysis of two samples from Subunit IC. A. Boundary between greenish and reddish clay (Section 308-U1324B-10H-6). B. XRD multiple diagram shows nearly identical results for single samples from the green clay and from the red clay. Note that the black line has background counts removed and green line has background counts retained in order to compare the two curves.

A

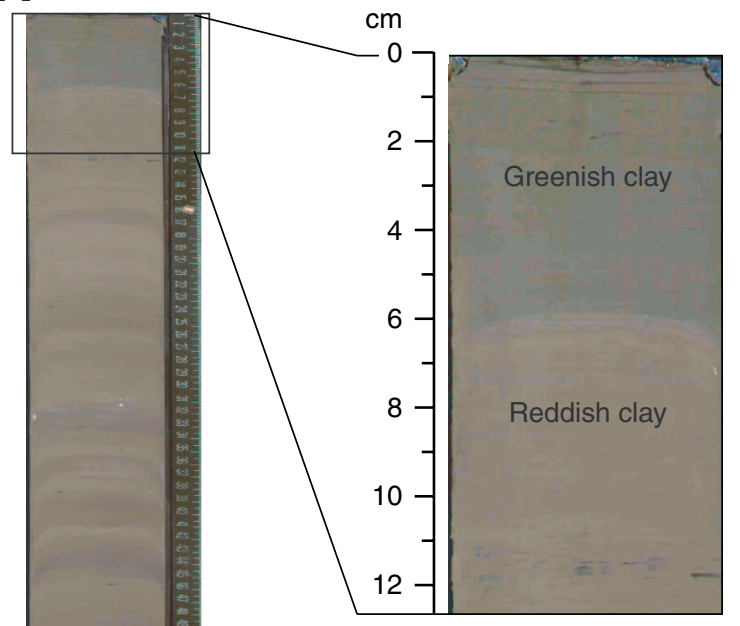

B

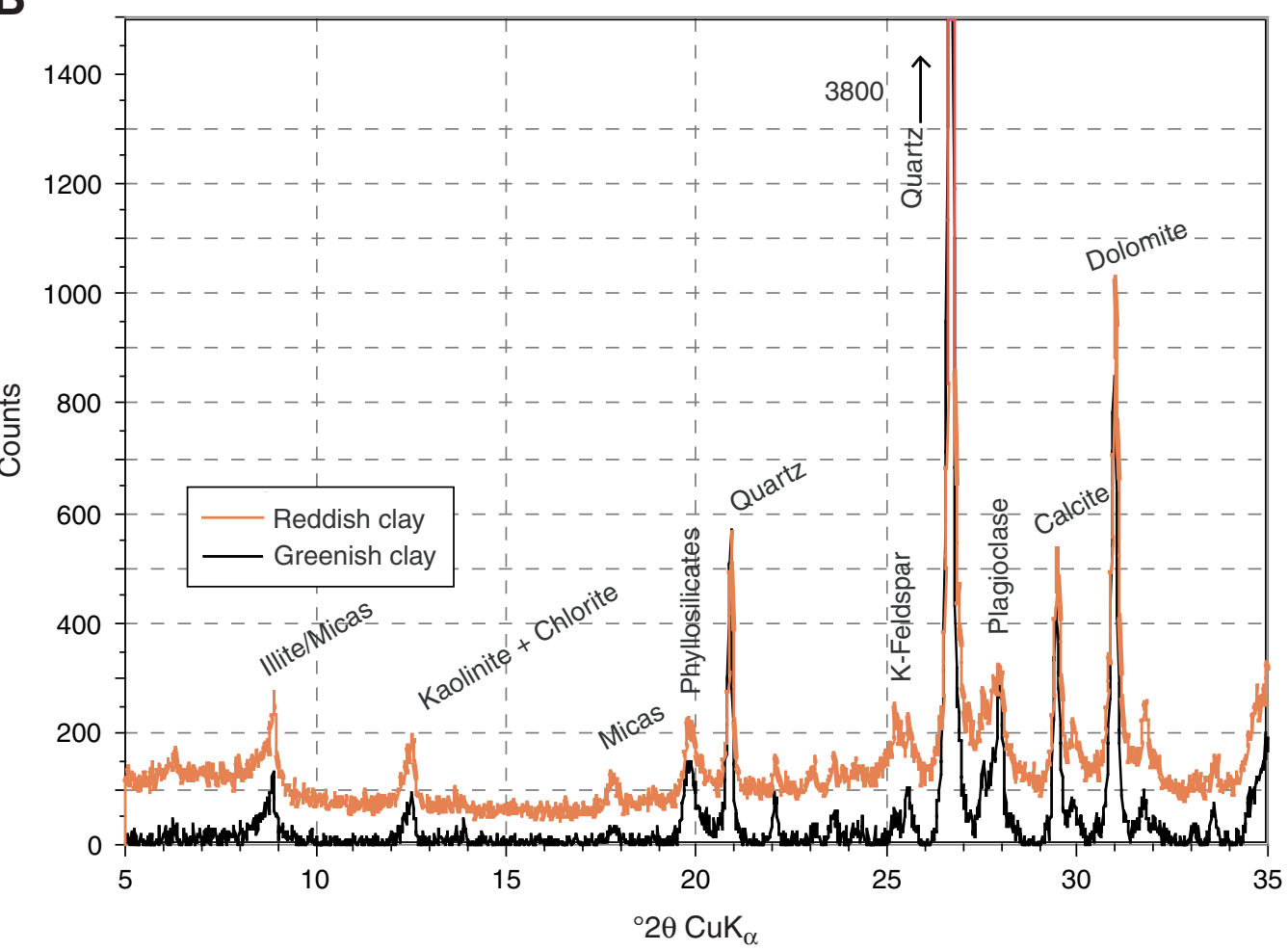


Figure F16. Biostratigraphic summary for Site U1324 with nannofossil and planktonic foraminifer zones and benthic foraminifer assemblages, gamma ray (GR) and resistivity (RES), seismic reflectors, natural remanent magnetization after $20 \mathrm{mT}$ AF demagnetization $\left(\mathrm{NRM}_{20 \mathrm{mT}}\right)$, and lithostratigraphy (see "Lithostratigraphy" and "Paleomagnetism").

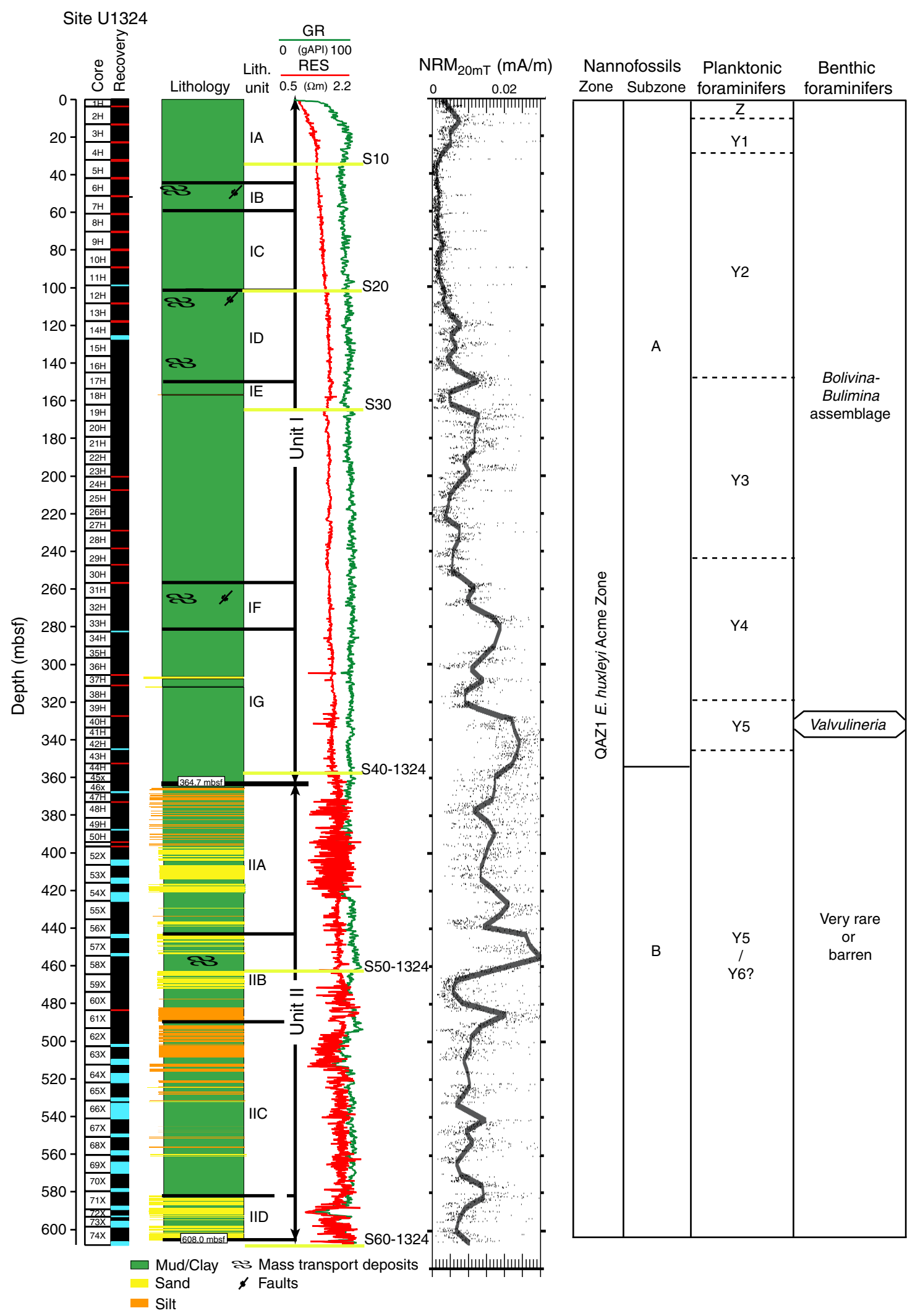


Figure F17. Distribution of stratigraphically important nannofossil groups in Hole U1324B.

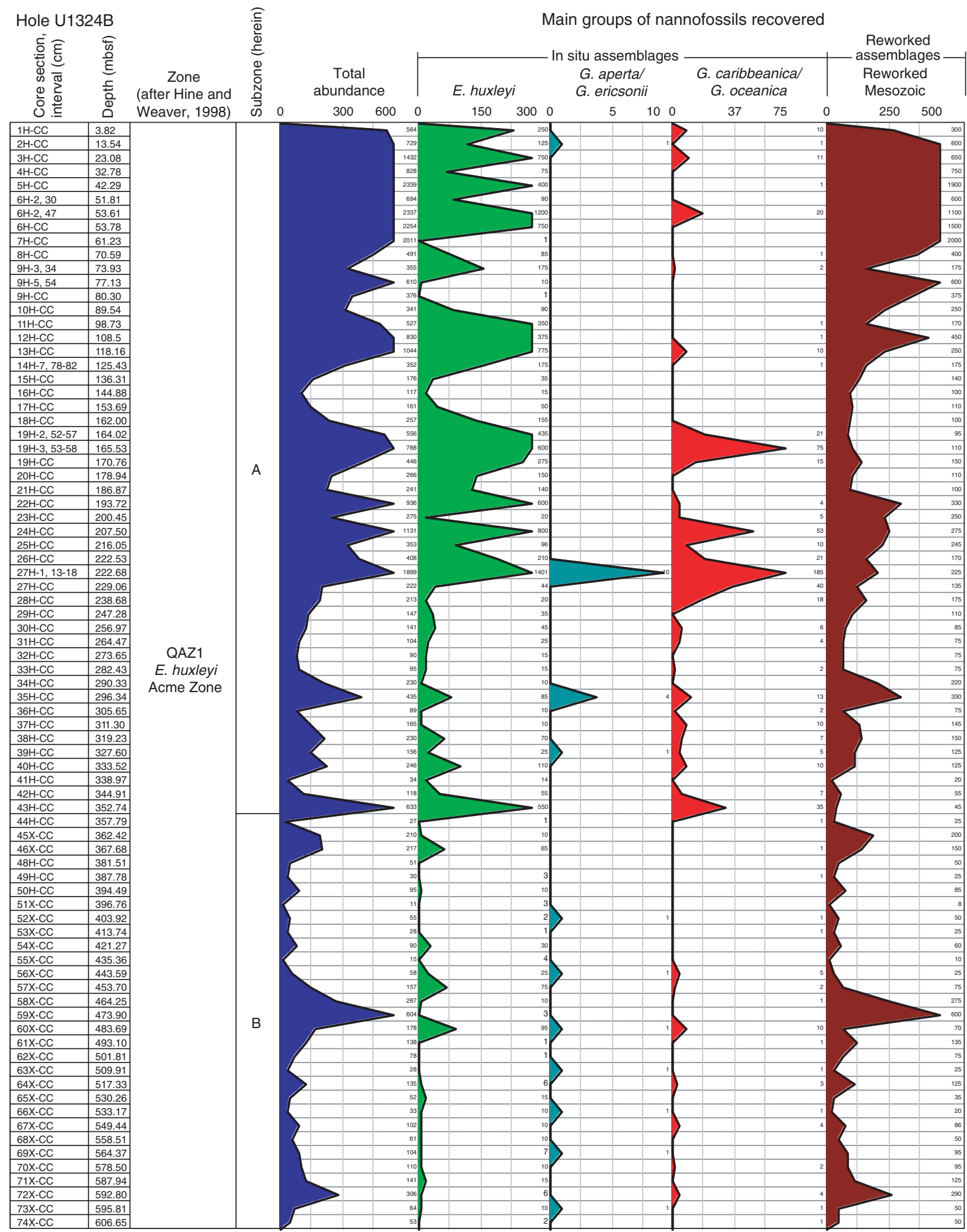


Figure F18. Distribution of stratigraphically important nannofossil groups in Holes U1324B and U1324C with lithostratigraphy from Hole U1324B. Note that high abundances of reworked Mesozoic nannofossils correlate well with mass transport deposits (shaded).

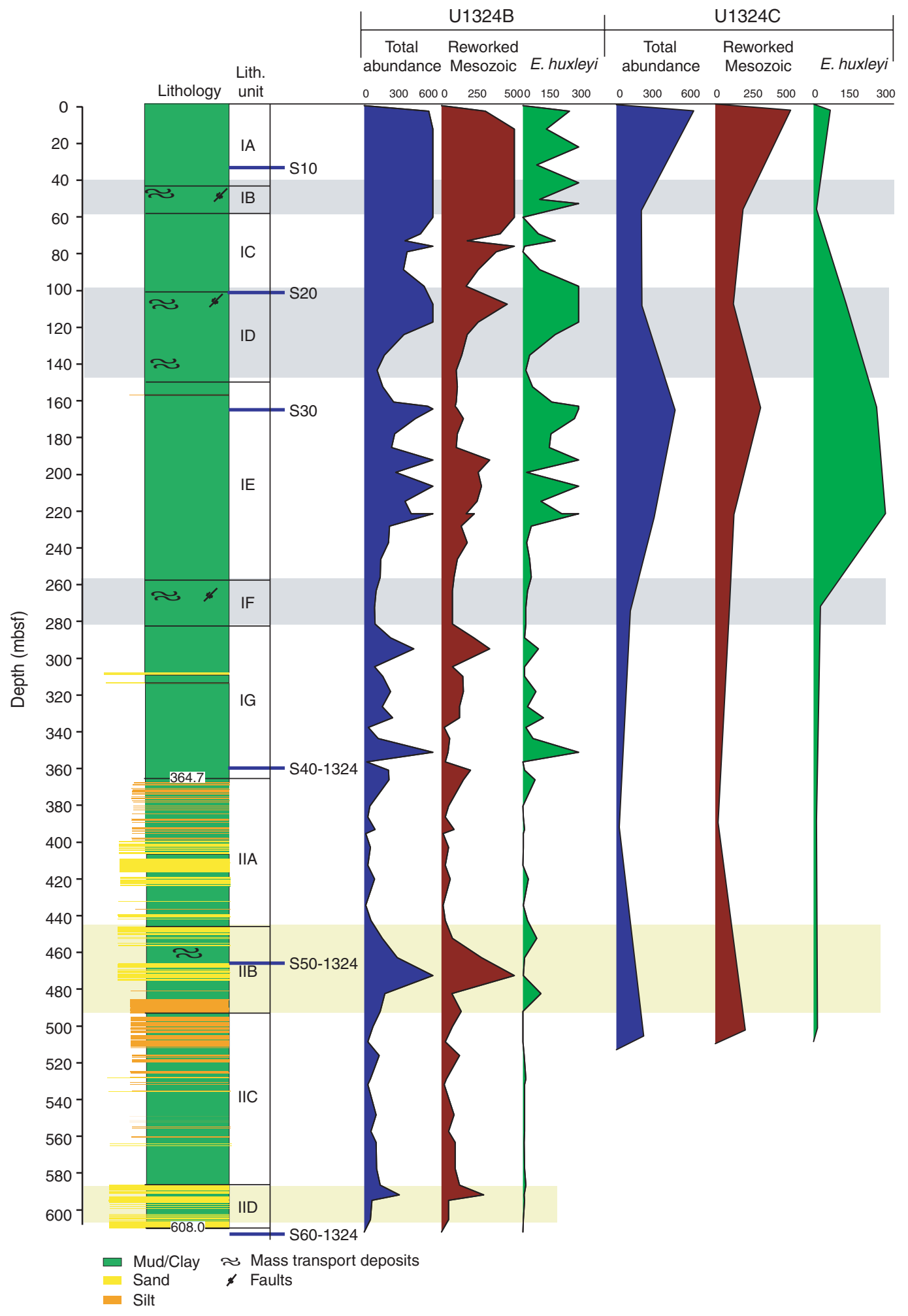


Figure F19. General distribution of nannofossils from Hole U1324B, showing the sporadic pattern for most species. Nannofossil zonation is given.

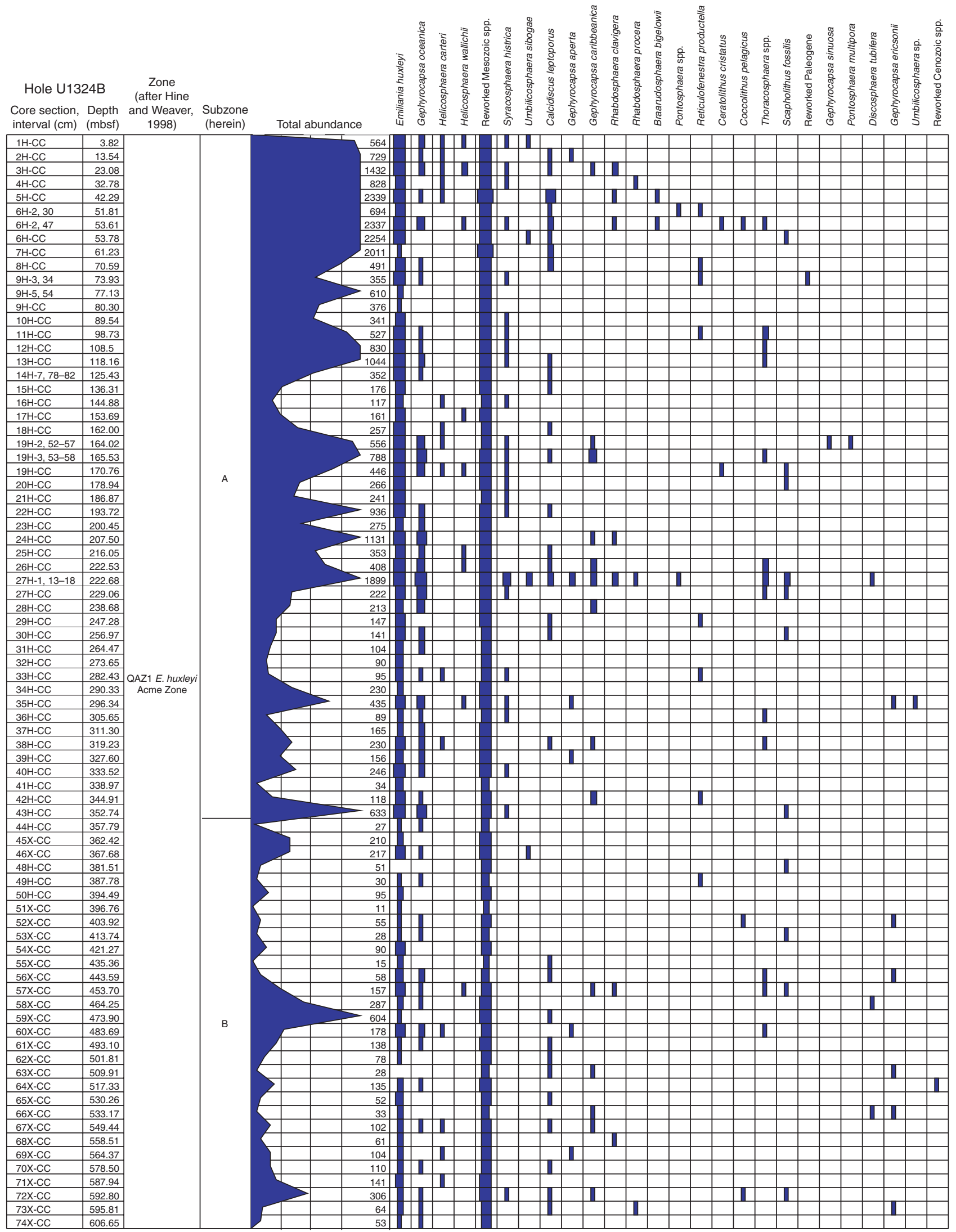


Figure F20. General distribution of nannofossils from Hole U1324C, showing the sporadic pattern for most species. Nannofossil zonation is given.

\begin{tabular}{|c|c|c|c|c|c|c|c|c|c|c|c|c|c|}
\hline $\begin{array}{l}\text { Hole U13 } \\
\text { Core section, } \\
\text { interval }(\mathrm{cm})\end{array}$ & $\begin{array}{l}24 \mathrm{C} \\
\text { Depth } \\
\text { (mbsf) }\end{array}$ & $\begin{array}{c}\text { Zone } \\
\text { (after Hine and } \\
\text { Weaver, 1998) }\end{array}$ & $\begin{array}{l}\text { Subzone } \\
\text { (herein) }\end{array}$ & Total abundance & & 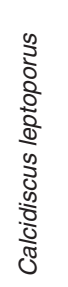 & 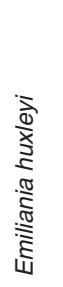 & 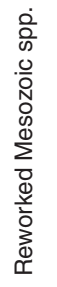 & 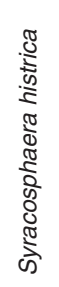 & 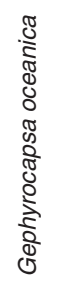 & 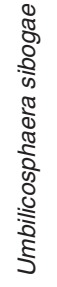 & 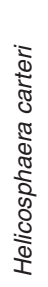 & 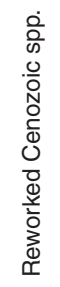 \\
\hline $1 \mathrm{H}-\mathrm{CC}$ & 59.61 & \multirow{8}{*}{$\begin{array}{l}\text { QAZ1 E. huxleyi } \\
\text { Acme Zone }\end{array}$} & \multirow{6}{*}{ A } & 1 & 1051 & & & & & & & & \\
\hline $2 \mathrm{H}-\mathrm{CC}$ & 108.85 & & & & 191 & & & & & & & & \\
\hline $3 \mathrm{H}-\mathrm{CC}$ & 155.46 & & & & 200 & & & & & & & & \\
\hline $4 \mathrm{H}-\mathrm{CC}$ & 206.45 & & & & 458 & & & & & & D & & \\
\hline $5 \mathrm{H}-\mathrm{CC}$ & 258.33 & & & & 296 & & & & & & & & \\
\hline $6 \mathrm{H}-\mathrm{CC}$ & 304.19 & & & & 111 & & & & & & & & \\
\hline $7 \mathrm{H}-\mathrm{CC}$ & 410.36 & & \multirow{2}{*}{ B } & & 27 & & & & & 1 & & & \\
\hline $8 \mathrm{H}-\mathrm{CC}$ & 511.80 & & & & 210 & & & & & & & & \\
\hline
\end{tabular}


Figure F21. Planktonic foraminifer biostratigraphy and abundance of selected taxa from Hole U1324B along with lithostratigraphic units, seismic reflectors, and marine isotopic stages (MIS).

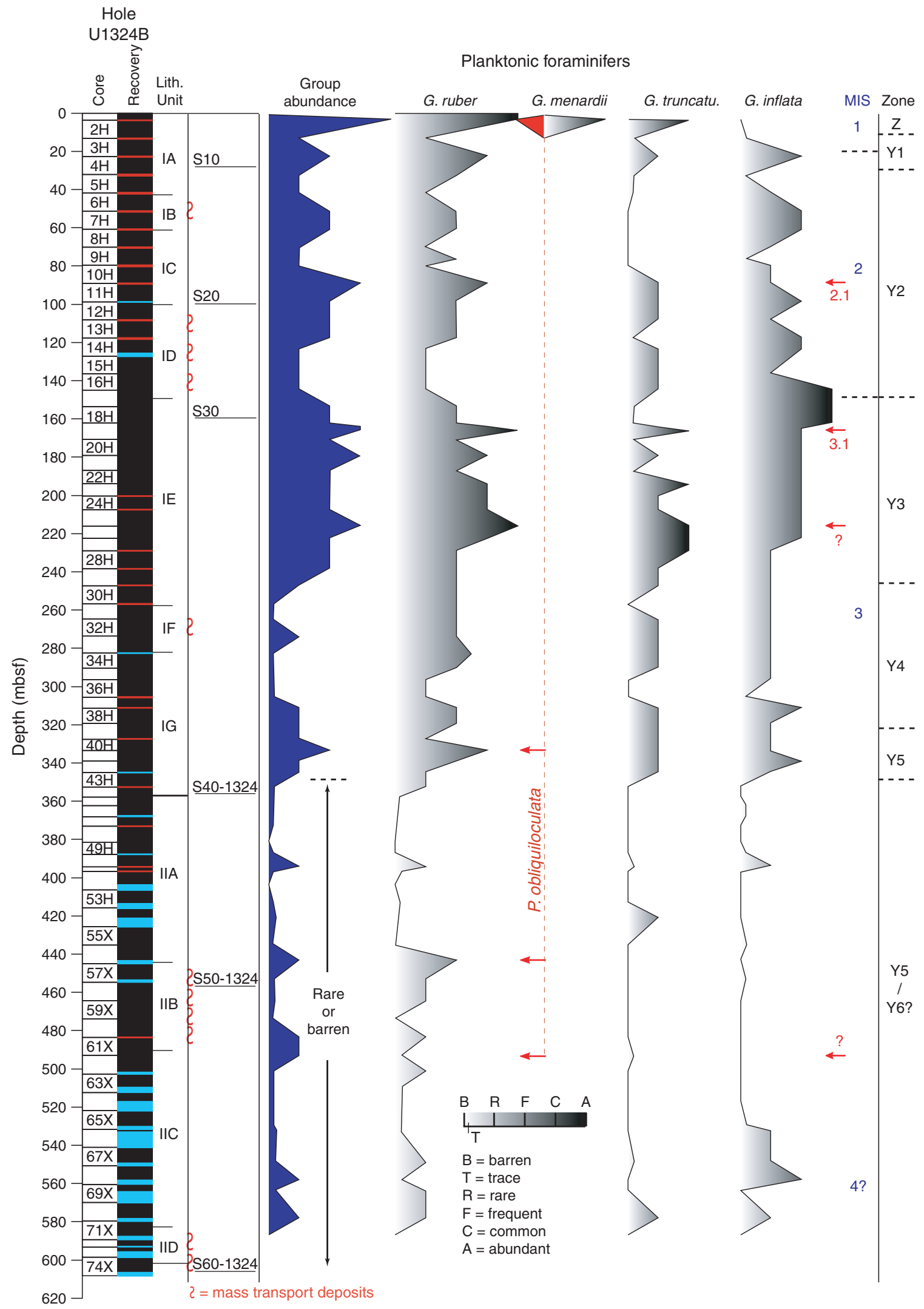


Figure F22. Distribution of selected epifaunal and infaunal benthic foraminifer species from Hole U1324B along with lithostratigraphic units, seismic reflectors, and marine isotopic stages (MIS).

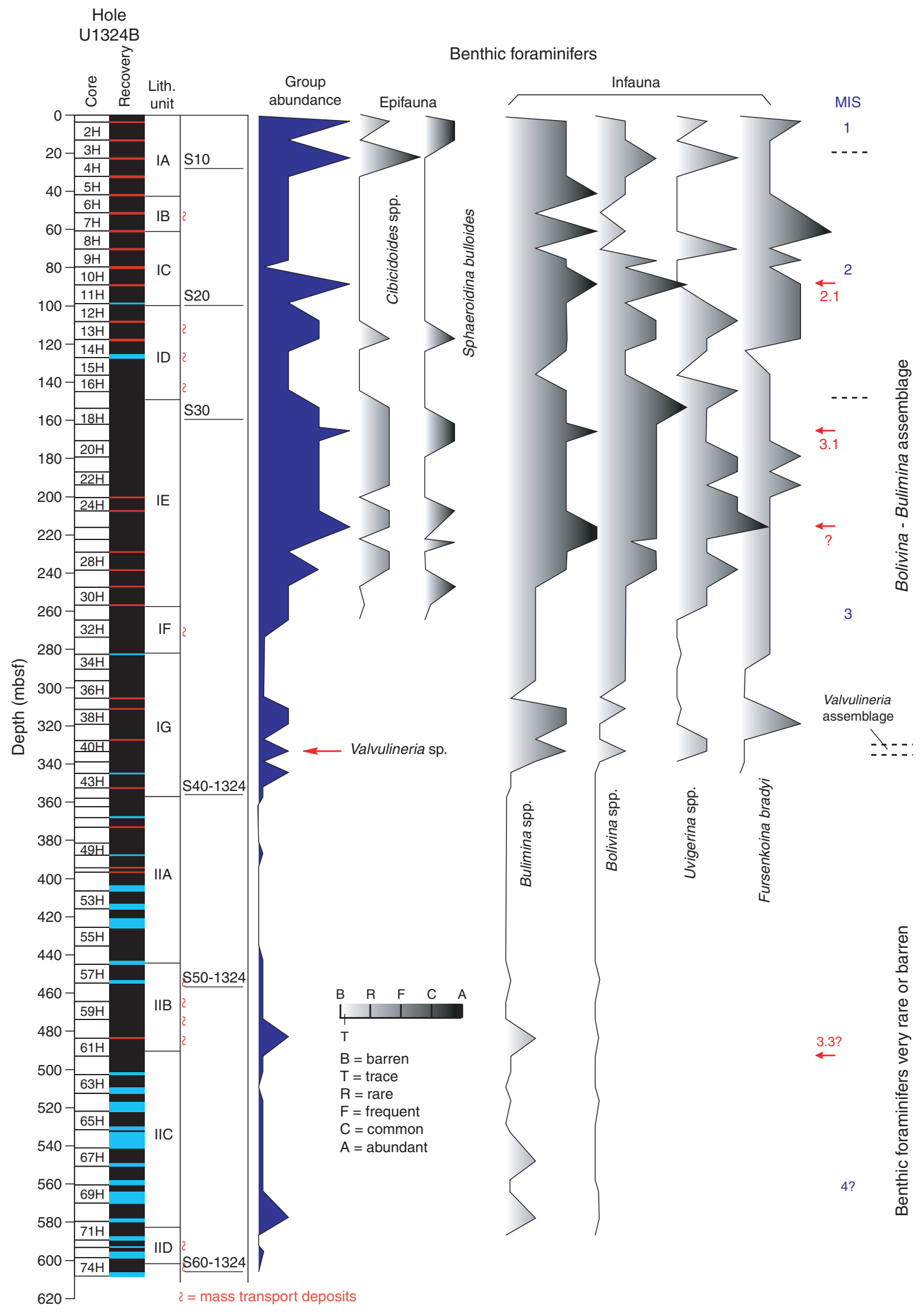


Figure F23. Microfossil and magnetostratigraphic datums and calculated sedimentation rates for Site U1324. Lithostratigraphy and seismic reflectors (SR) are described in "Background and objectives" and "Lithostratigraphy," respectively. $\mathrm{LO}=$ last occurrence.

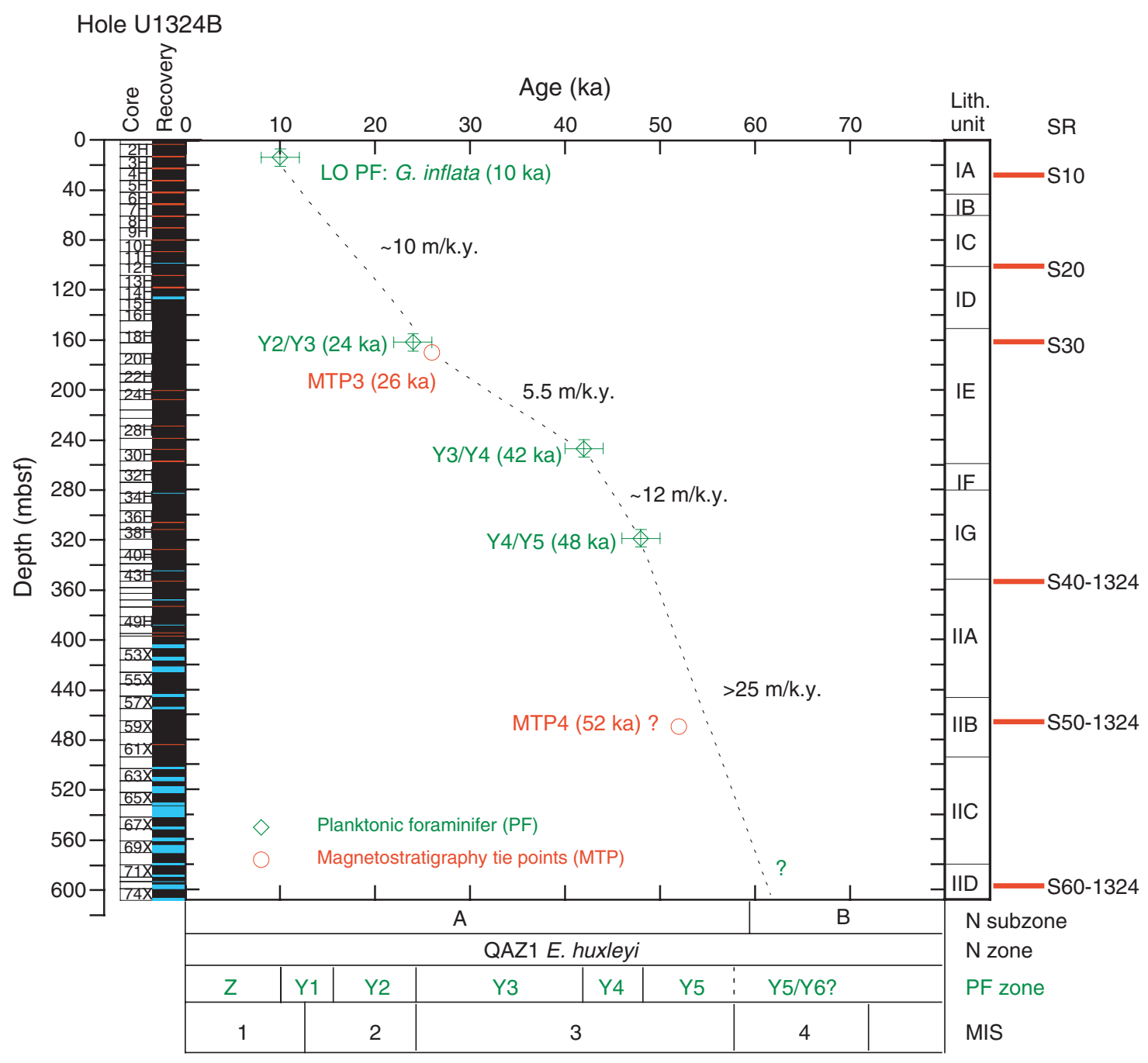


Figure F24. Uncorrected shipboard measurements (black dots) and running average (gray line) on archive-half core sections of (A) natural remanent magnetization after $20 \mathrm{mT}$ AF demagnetization $\left(\mathrm{NRM}_{20 \mathrm{mT}}\right)$, (B) declination (black $=$ cores recovered using a nonmagnetic APC cutting shoe, red $=$ cores recovered with the Fugro cutting shoe), and (C) inclination (black = APC cutting shoe, red = Fugro cutting shoe). Depths have been corrected for voids in the core; paleomagnetic intervals, lithostratigraphic units, and seismic reflectors $(\mathrm{SF}=$ seafloor) are also shown.

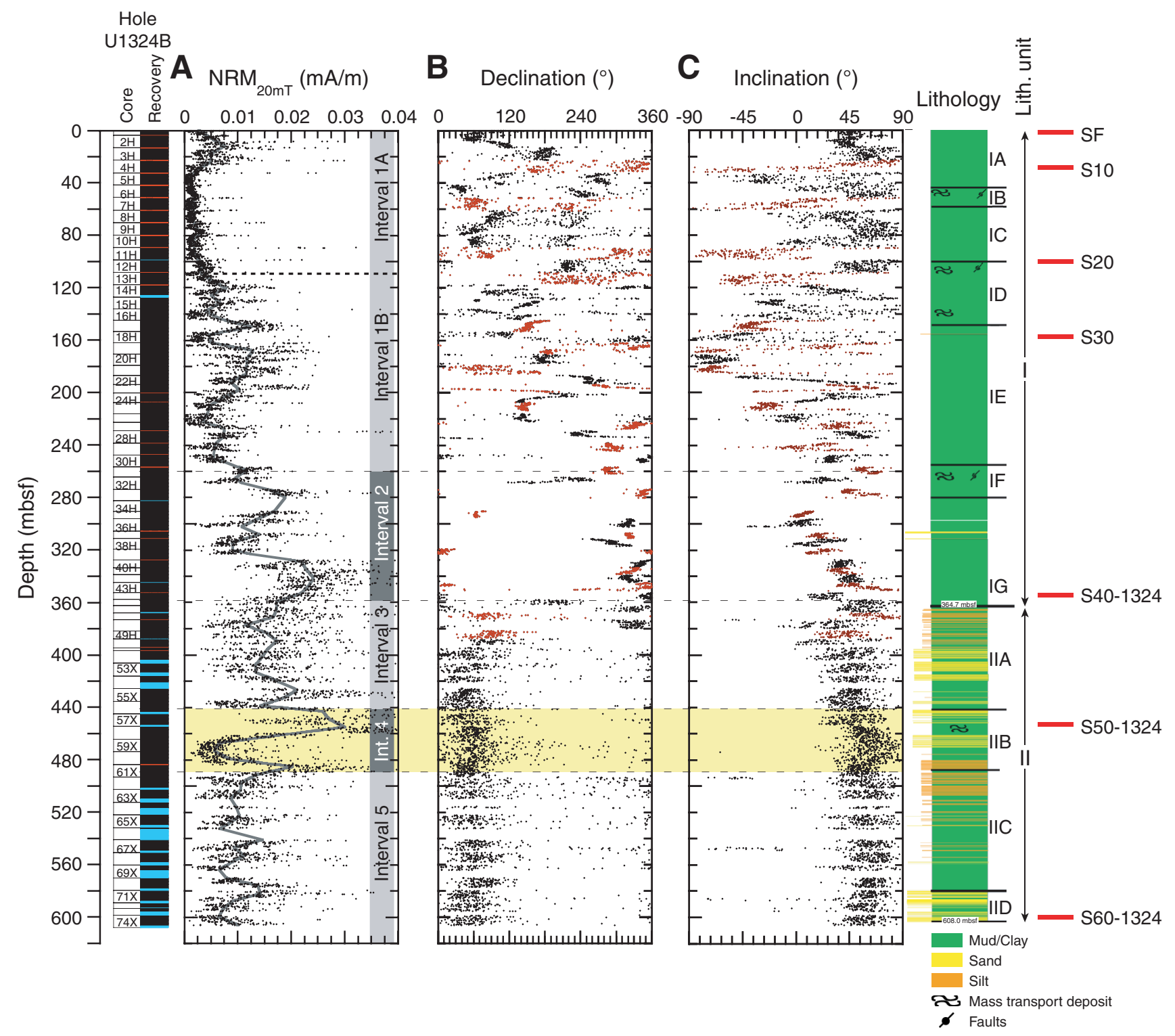


Figure F25. Magnetostratigraphic data (black dots) and running average (gray lines) of Hole U1324B. A. $\delta^{18} \mathrm{O}$ record (Bassinot et al., 1994, solid line) and Subtropical South Atlantic Susceptibility stack (von Dobeneck and Schmiedert, 1999, dashed line) vs. age, and marine isotope stages (MIS) 1.1, 2.2, 3.1, 3.3. B. Natural remanent magnetization after $20 \mathrm{mT}$ AF demagnetization $\left(\mathrm{NRM}_{20 \mathrm{mT}}\right)$, showing the graphical correlation of the magnetostratigraphic tie points (MTP1-MTP4) with marine isotopic stages. C. MS2F sensor magnetic point susceptibility ( $\kappa$ ) performed on archive halves at $10 \mathrm{~cm}$ resolution. D. Multisensor track (MST) $\kappa$ measured on whole cores at $6 \mathrm{~cm}$ resolution. Depths have been corrected for voids in the core; lithostratigraphic units, magnetostratigraphic intervals, and seismic reflectors $(\mathrm{SF}=$ seafloor $)$ are also shown.

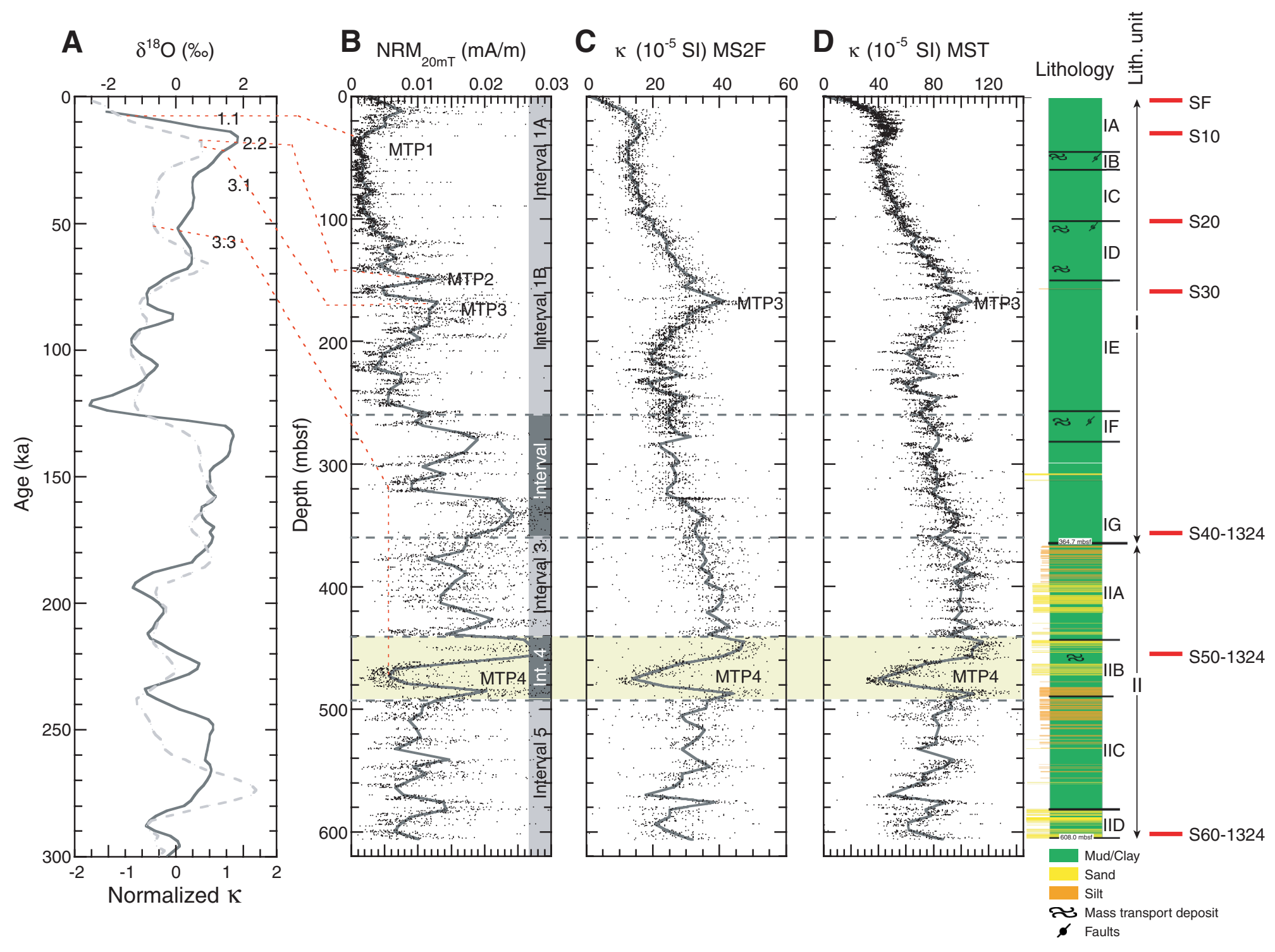


Figure F26. Interstitial water concentration profiles for alkalinity, $\mathrm{pH}$, salinity, and chlorinity (black symbols $=$ Hole U1324B, gray symbols $=$ Hole U1324C) along with seismic reflectors (SF = seafloor) and lithostratigraphic units.

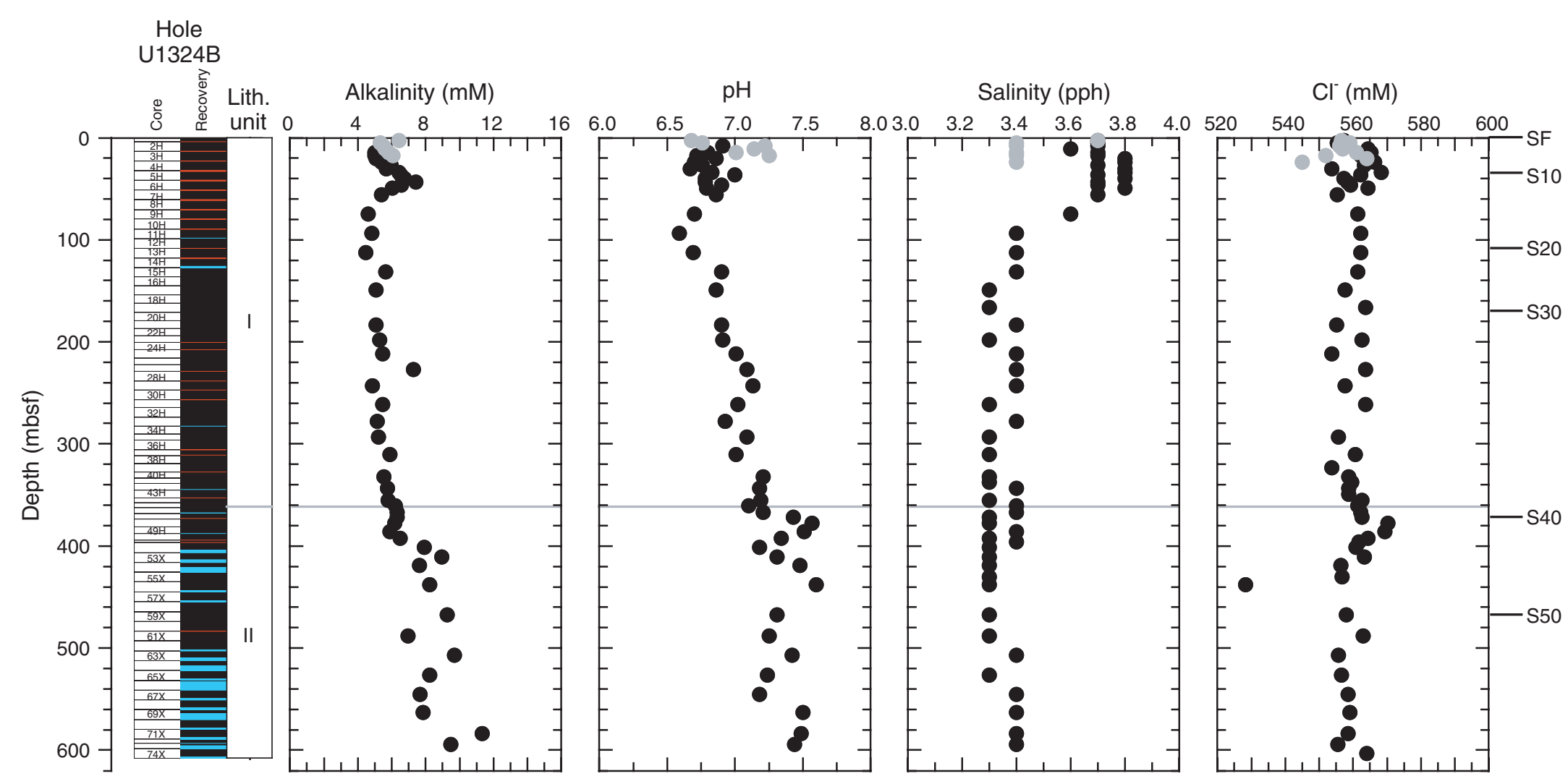


Figure F27. Interstitial water concentration profiles $\mathrm{SO}_{4}{ }^{2-}, \mathrm{NH}_{4}{ }^{+}, \mathrm{PO}_{4}{ }^{3-}$, and $\mathrm{H}_{4} \mathrm{SiO}_{4}$ (black symbols $=$ Hole U1324B, gray symbols $=\mathrm{Hole} \mathrm{U} 1324 \mathrm{C}$ ) along with seismic reflectors $(\mathrm{SF}=$ seafloor) and lithostratigraphic units.

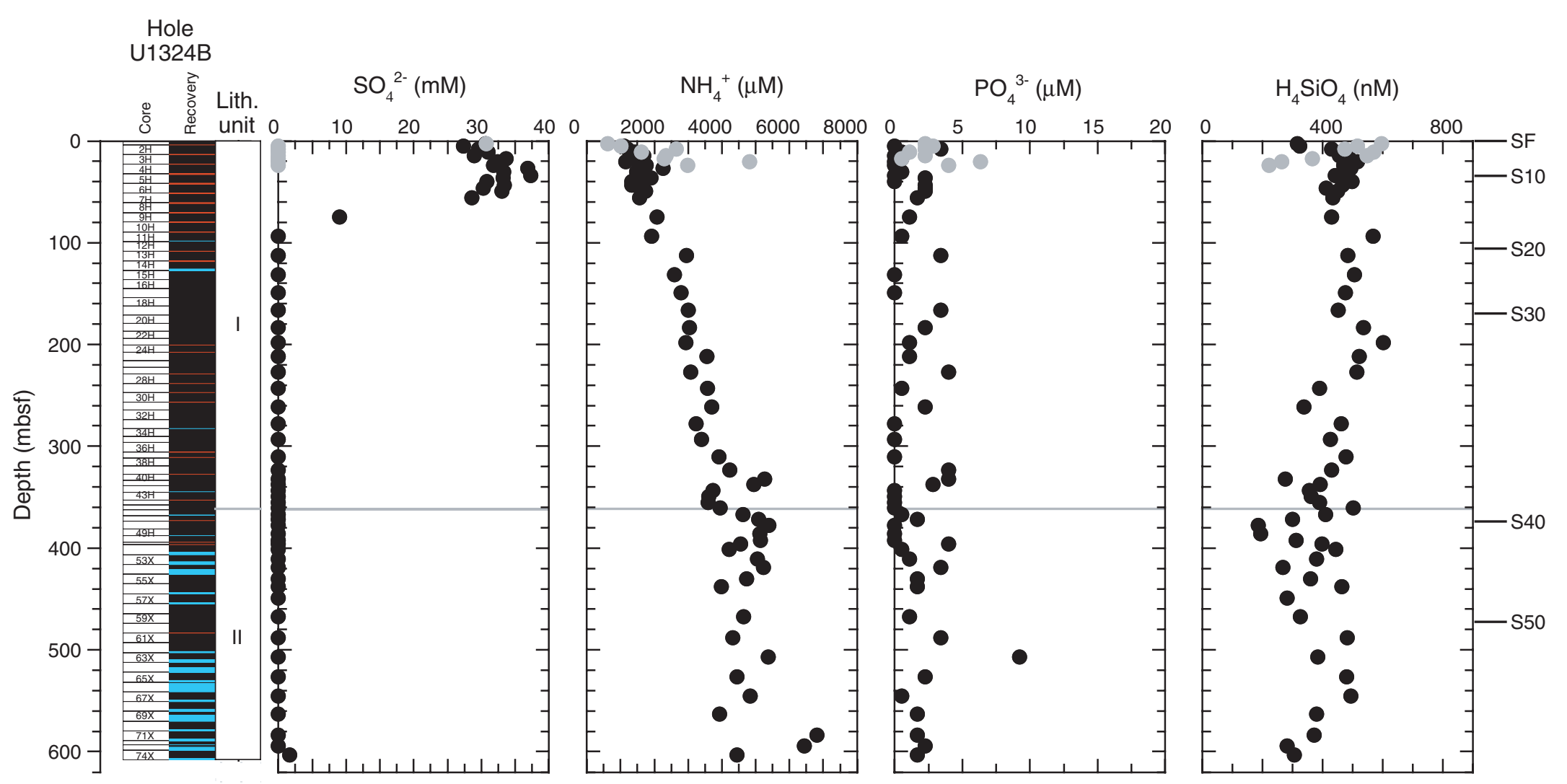


Figure F28. Interstitial water concentration profiles for major cations $\mathrm{Na}^{+}, \mathrm{K}^{+}, \mathrm{Ca}^{2+}, \mathrm{Mg}^{2+}($ black symbols $=\mathrm{Hole} \mathrm{U} 1324 \mathrm{~B}$, gray symbols $=\mathrm{Hole}$ U1324C) along with seismic reflectors (SF = seafloor) and lithostratigraphic units.

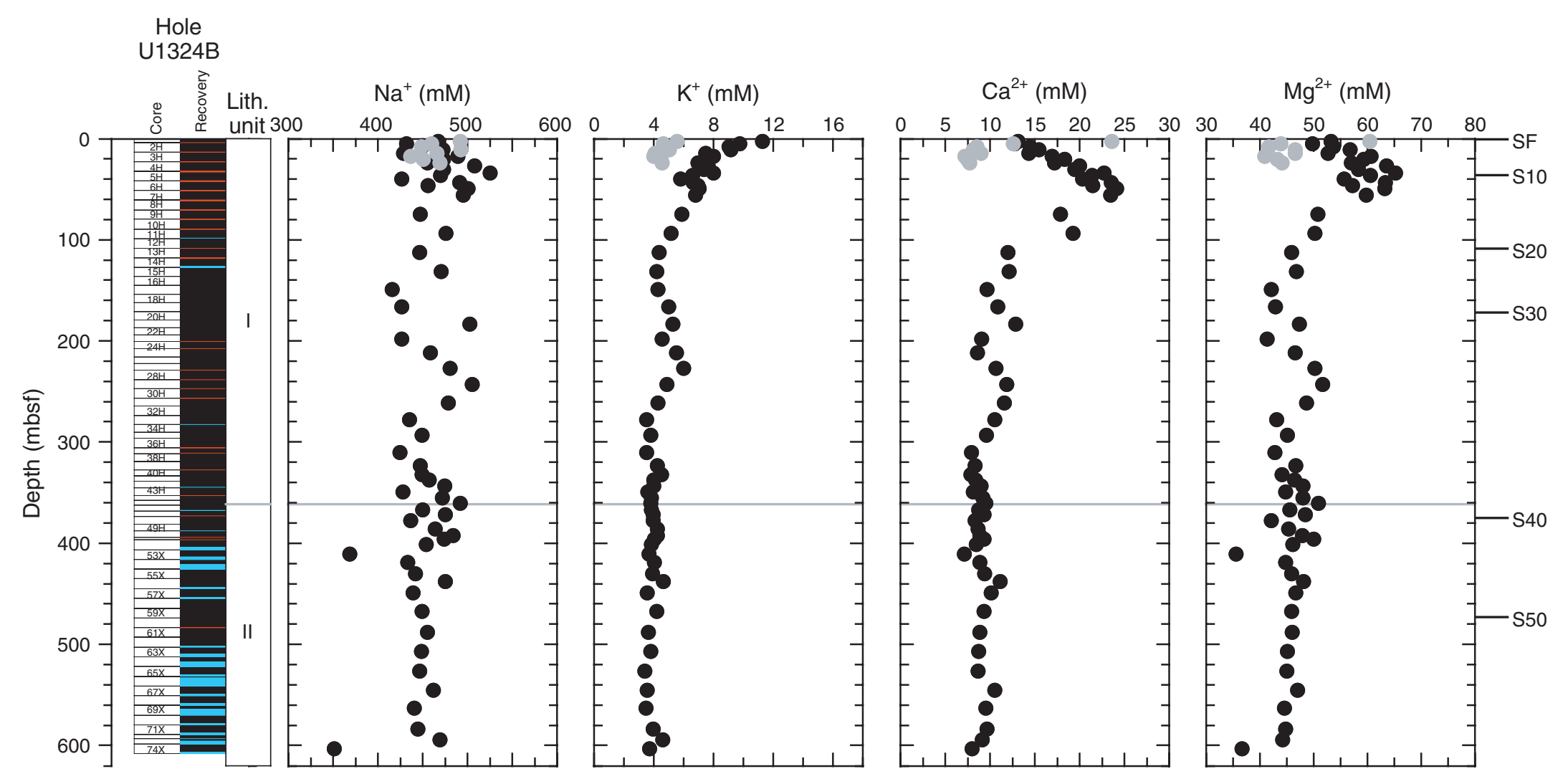


Figure F29. Interstitial water concentration profiles for trace metals (black symbols $=$ Hole U1324B, gray symbols $=$ Hole U1324C) along with seismic reflectors $(\mathrm{SF}=$ seafloor $)$ and lithostratigraphic units. $\mathrm{B}^{3+}, \mathrm{Li}^{+}$, and $\mathrm{Sr}^{2+}$ (continued on next page).

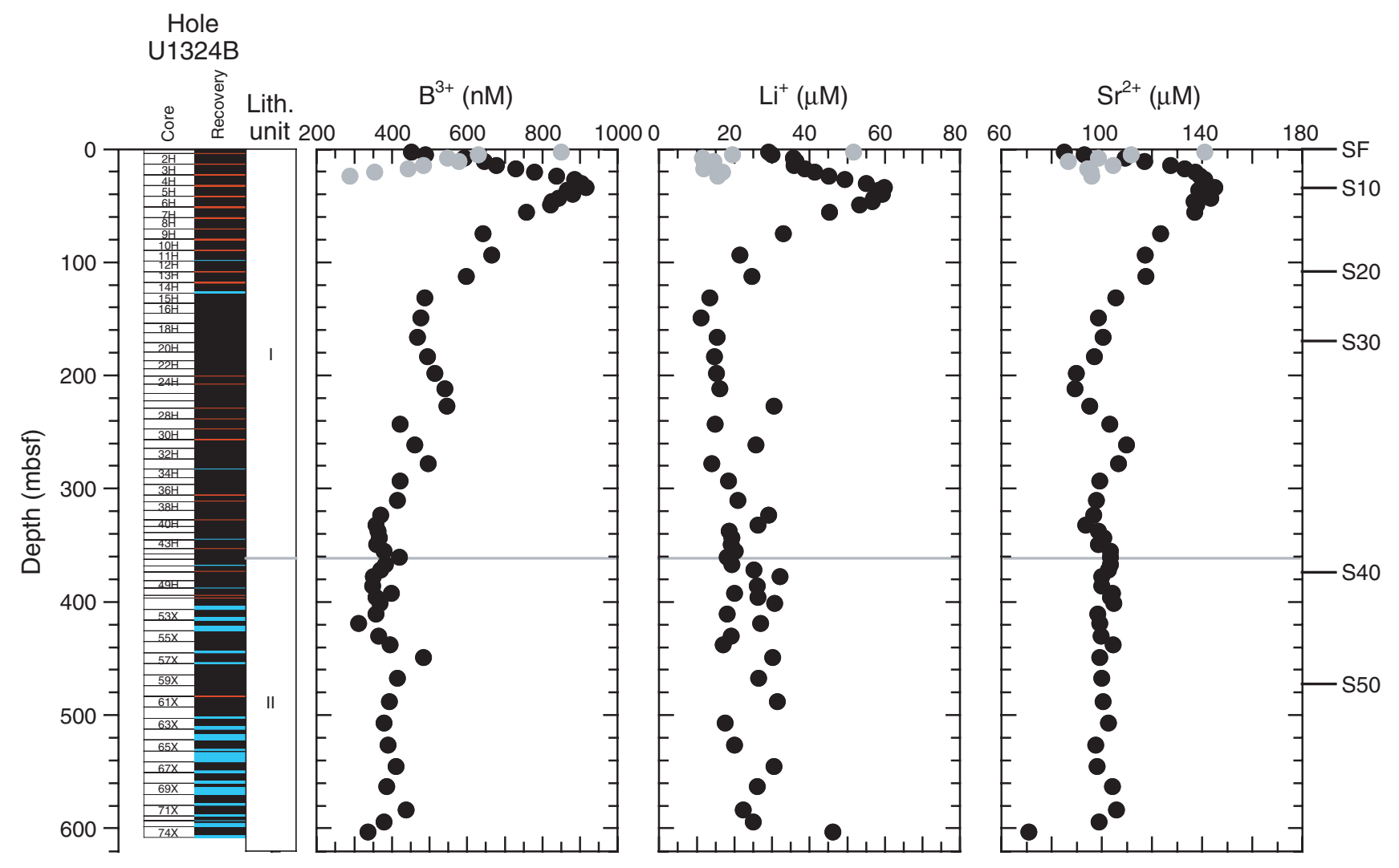


Figure F29 (continued). $\mathrm{Ba}^{2+}, \mathrm{Fe}^{2+}$, and $\mathrm{Mn}^{2+}$.

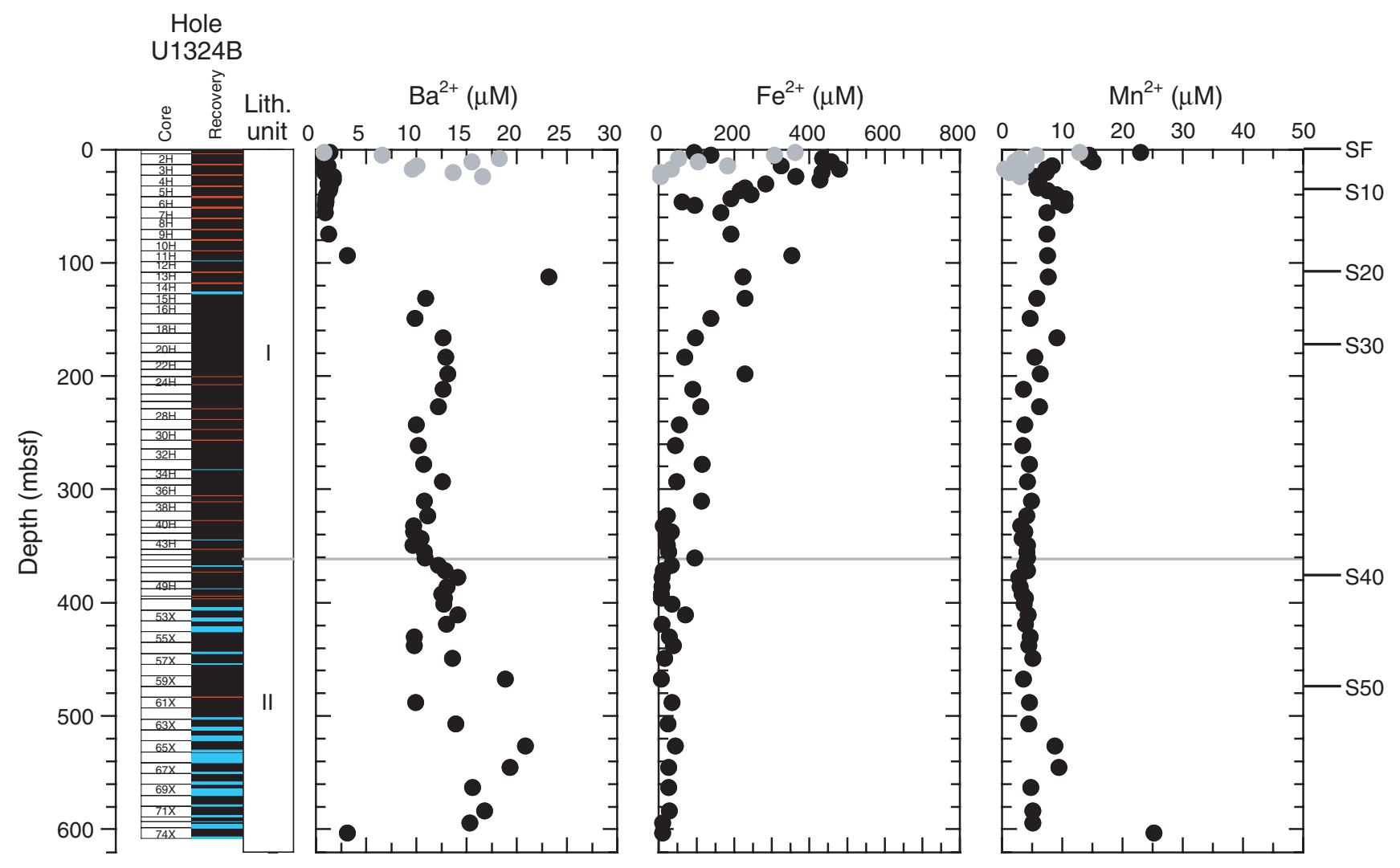


Figure F30. Downhole variations in total inorganic carbon (TIC), calcium carbonate $\left(\mathrm{CaCO}_{3}\right)$, total organic carbon (TOC), total nitrogen (TN), molar ratio of organic carbon to total nitrogen $(\mathrm{C} / \mathrm{N})$, and total hydrogen $(\mathrm{TH})$ in sediments at Site U1324 (black symbols = Hole U1324B, gray symbols $=$ Hole U1324C) along with seismic reflectors $(\mathrm{SF}=$ seafloor $)$ and lithostratigraphic units.

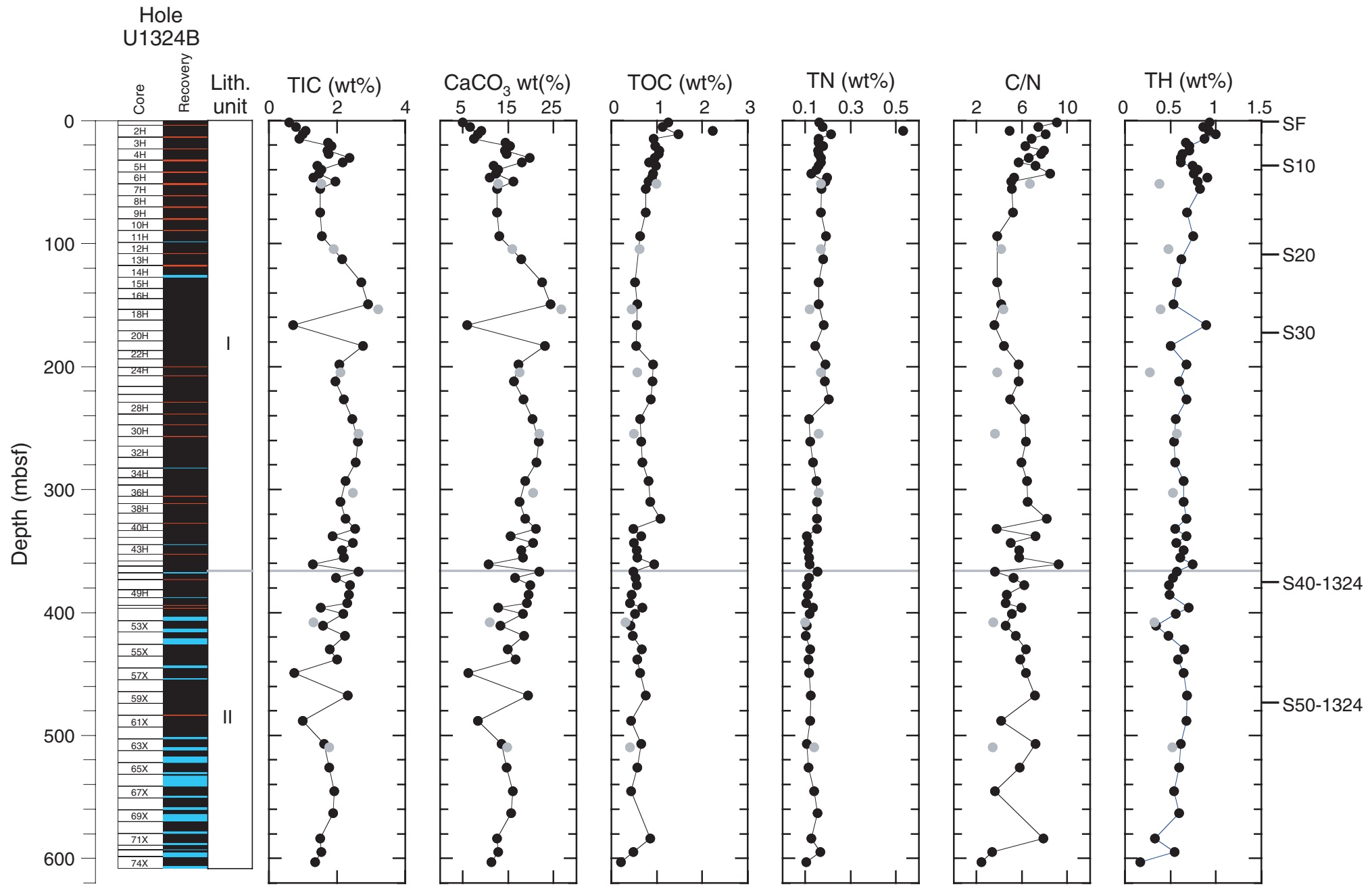


Figure F31. Headspace gas concentrations of methane and ethane in Hole U1324B along with seismic reflectors $(\mathrm{SF}=$ seafloor $)$ and lithostratigraphic units.

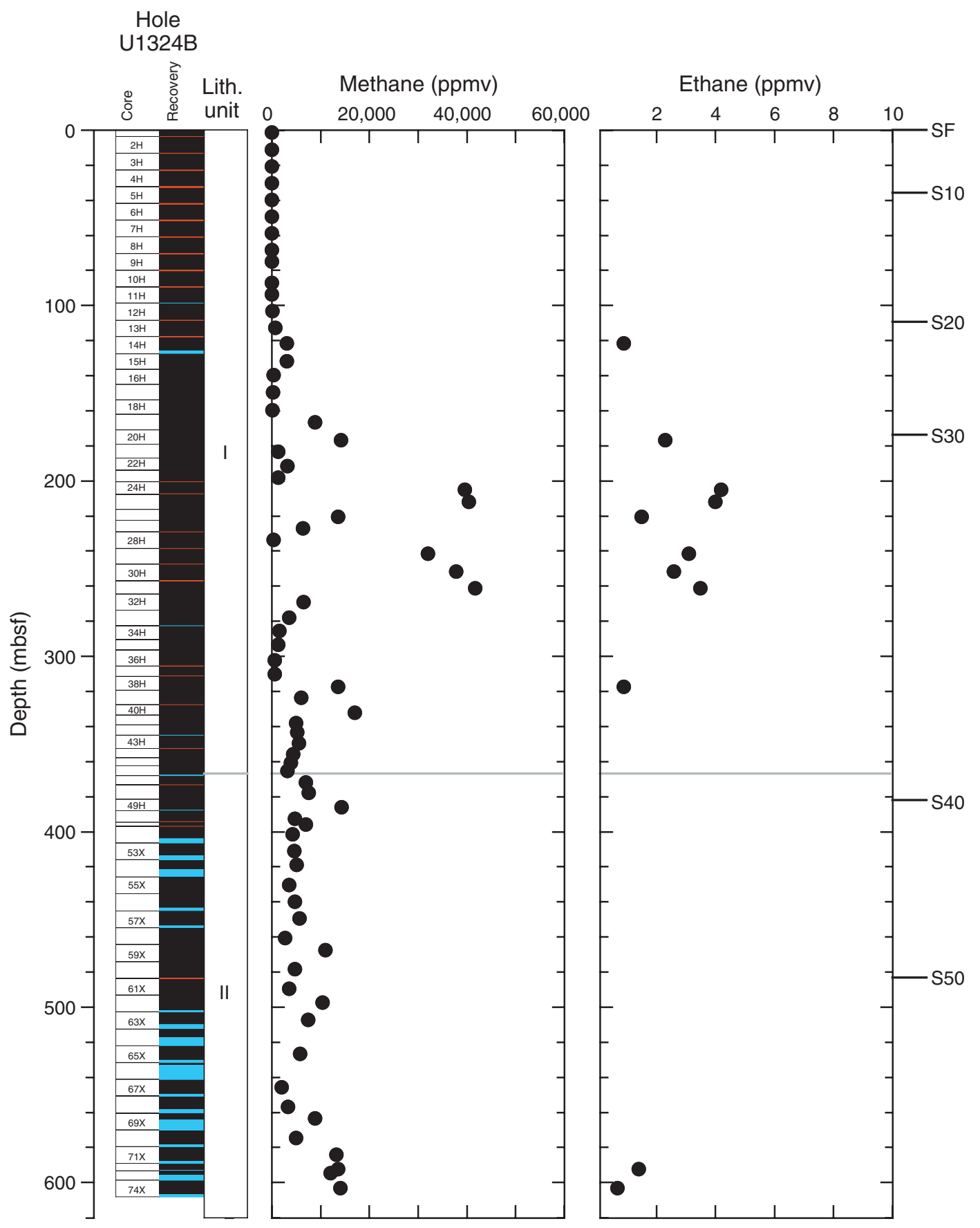


Figure F32. Methane and sulfate concentration profiles in Hole U1324B along with seismic reflectors (SF $=$ seafloor) and lithostratigraphic units.

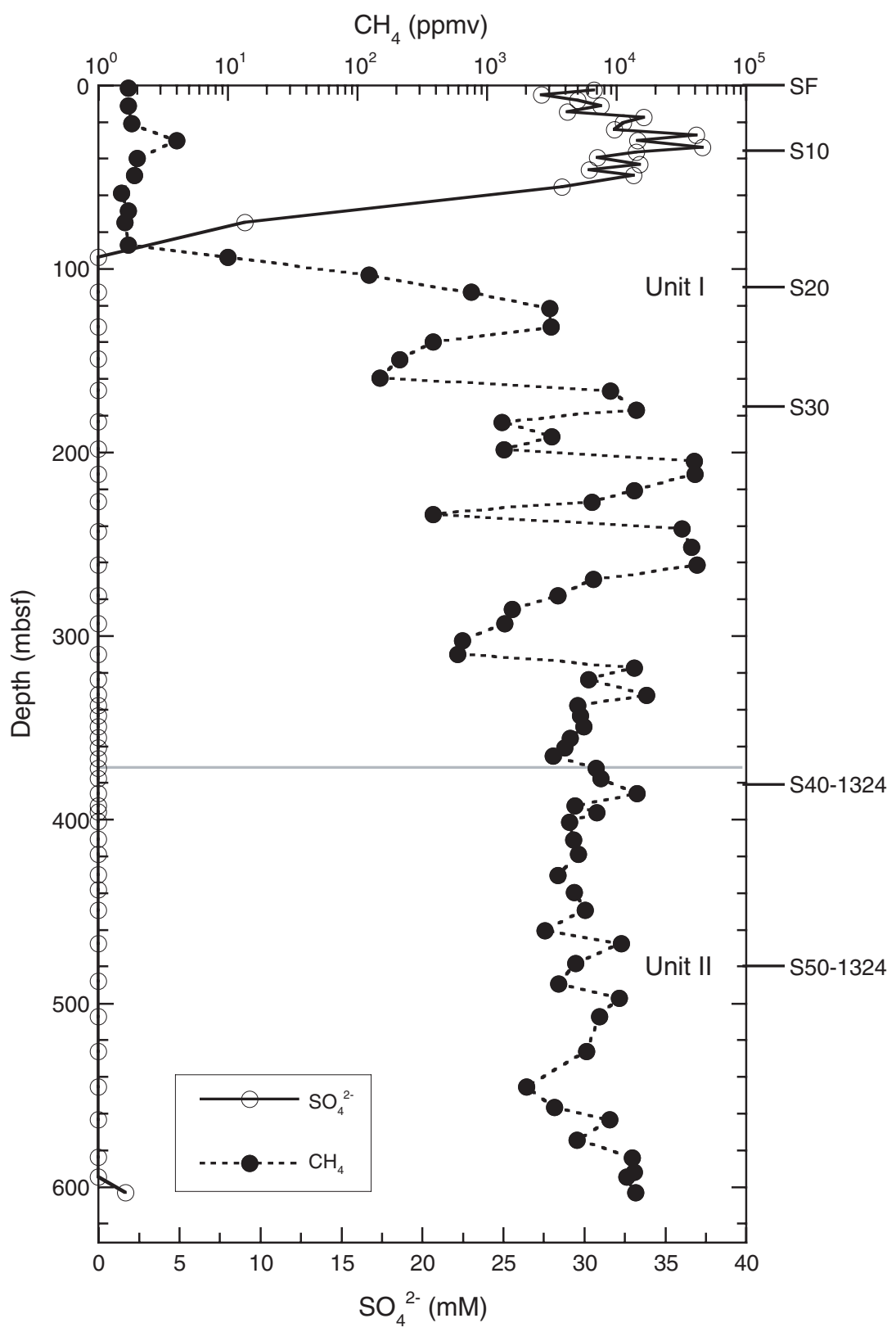


Figure F33. Vertical profile of cell density in Hole U1324B (solid symbols = cell density, open symbols = not detected or not significant amounts) along with seismic reflectors $(\mathrm{SF}=$ seafloor $)$ and lithostratigraphic units.

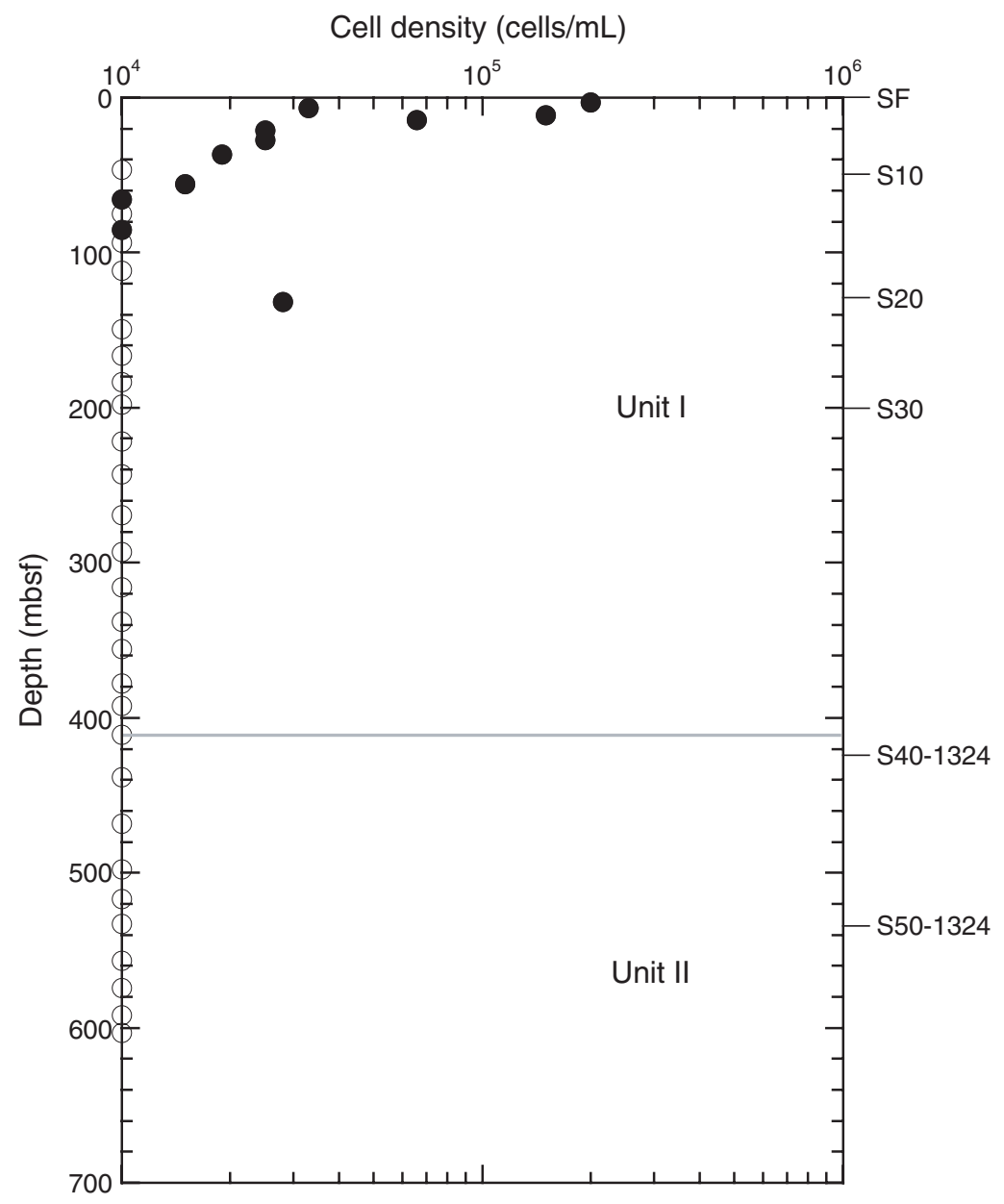


Figure F34. A. Bulk density determined from gamma ray attenuation (GRA) on unsplit cores and from moisture and density (MAD) measurements on discrete samples. Image-derived density (IDRO) from loggingwhile-drilling (LWD) data are overlain for comparison. B. Grain density profile determined from MAD measurements. C. Porosity obtained from MAD measurements and porosity calculated from IDRO density assuming a constant grain density of $2.7 \mathrm{~g} / \mathrm{cm}^{3}$ and a pore water density of $1.024 \mathrm{~g} / \mathrm{cm}^{3}$. Yellow = mass transport deposits (see "Lithostratigraphy"). SF = seafloor.

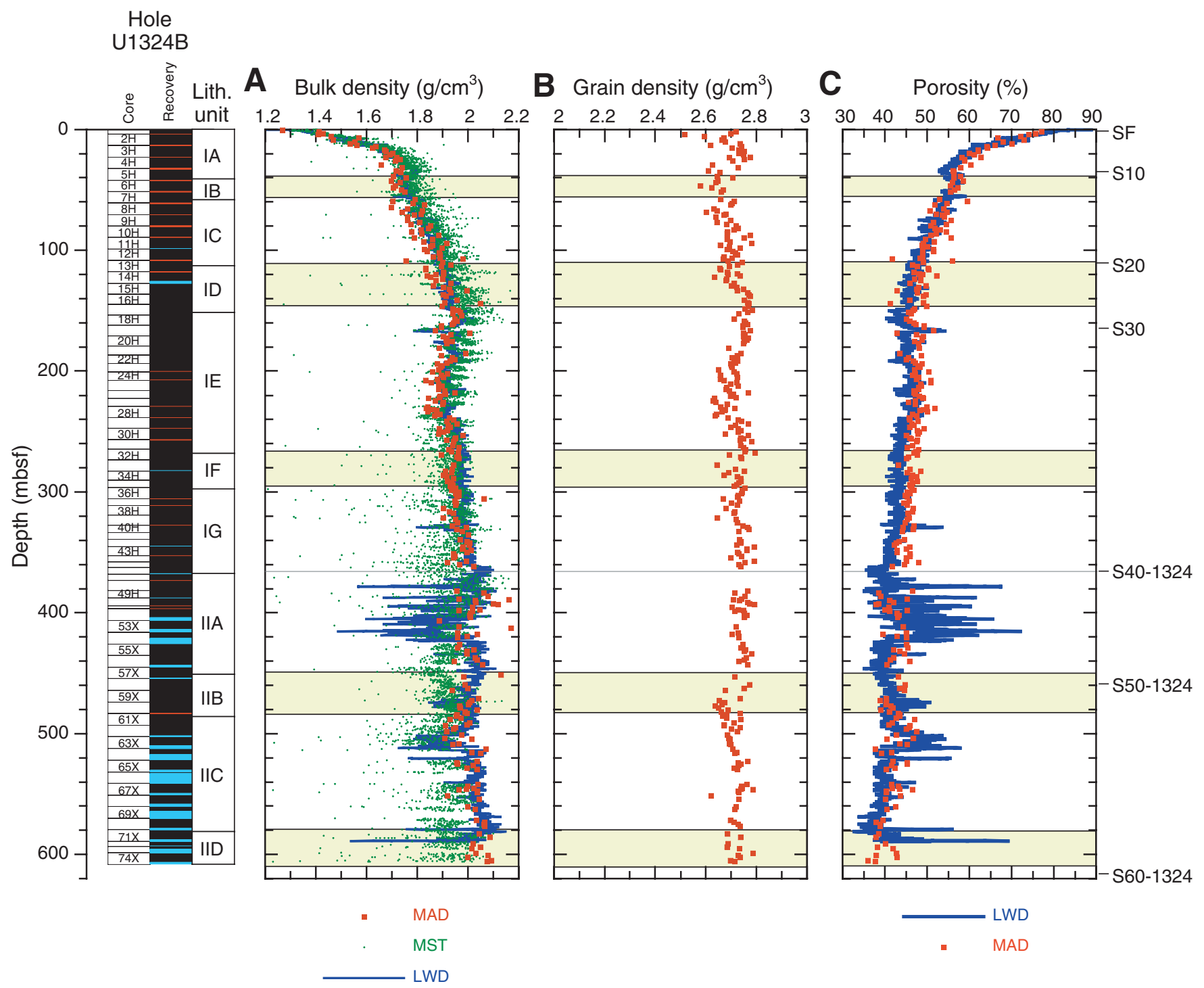


Figure F35. A. Noncontact resistivity (from MST core logging). B. Resistivity from wireline logging plotted along with seismic reflectors ( $\mathrm{SF}=$ seafloor; see "Background and objectives") and lithostratigraphic units.

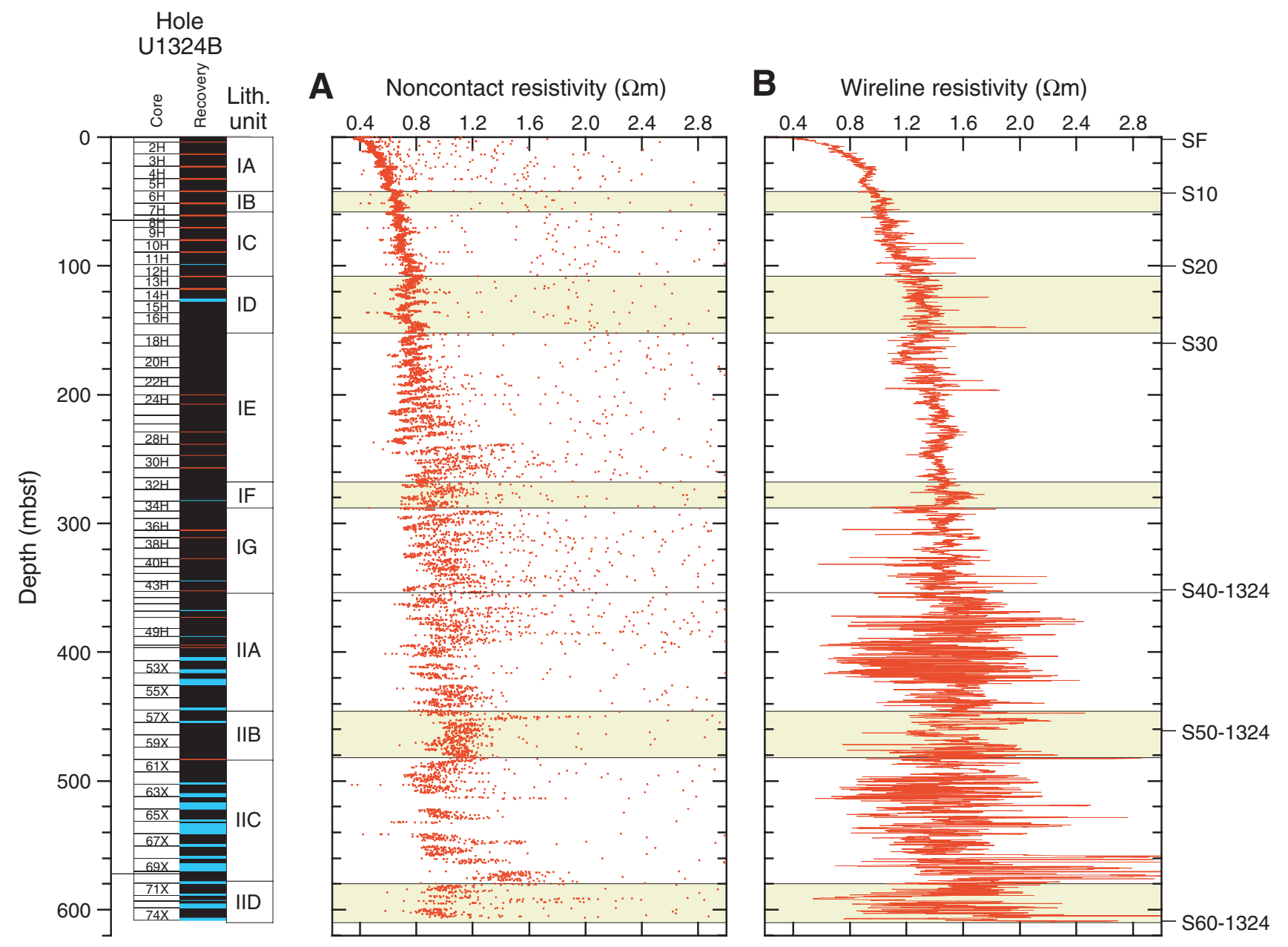


Figure F36. Magnetic susceptibility (MS) plotted along with seismic reflectors (SF = seafloor; see "Background and objectives"). Yellow = mass transport deposits.

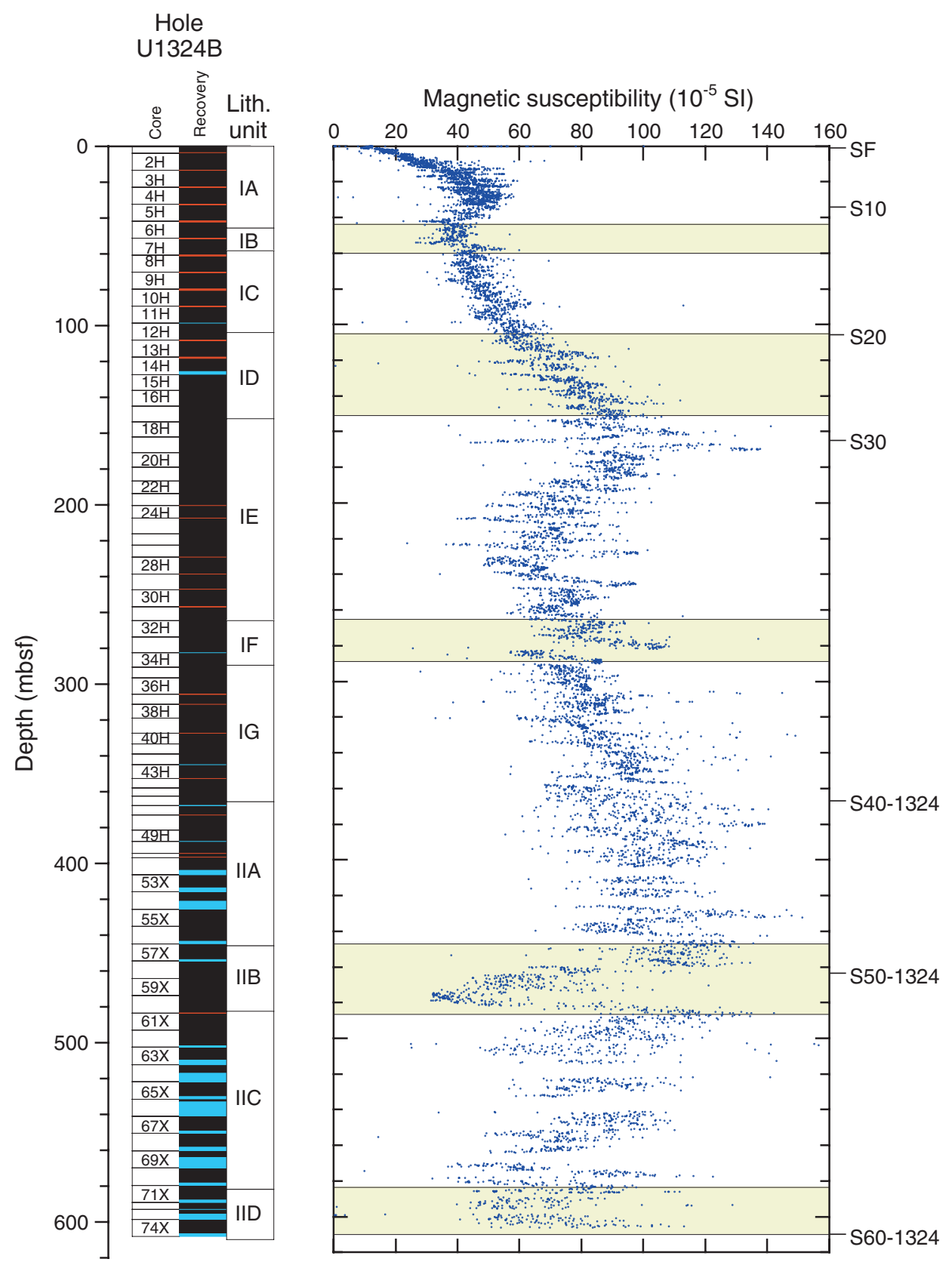


Figure F37. A. Thermal conductivity. B. In situ temperatures measured using the temperature/dual pressure (T2P) probe and Davis-Villinger Temperature-Pressure Probe (DVTPP), plotted along with seismic reflectors (SF $=$ seafloor $)$. Yellow $=$ mass transport deposits.

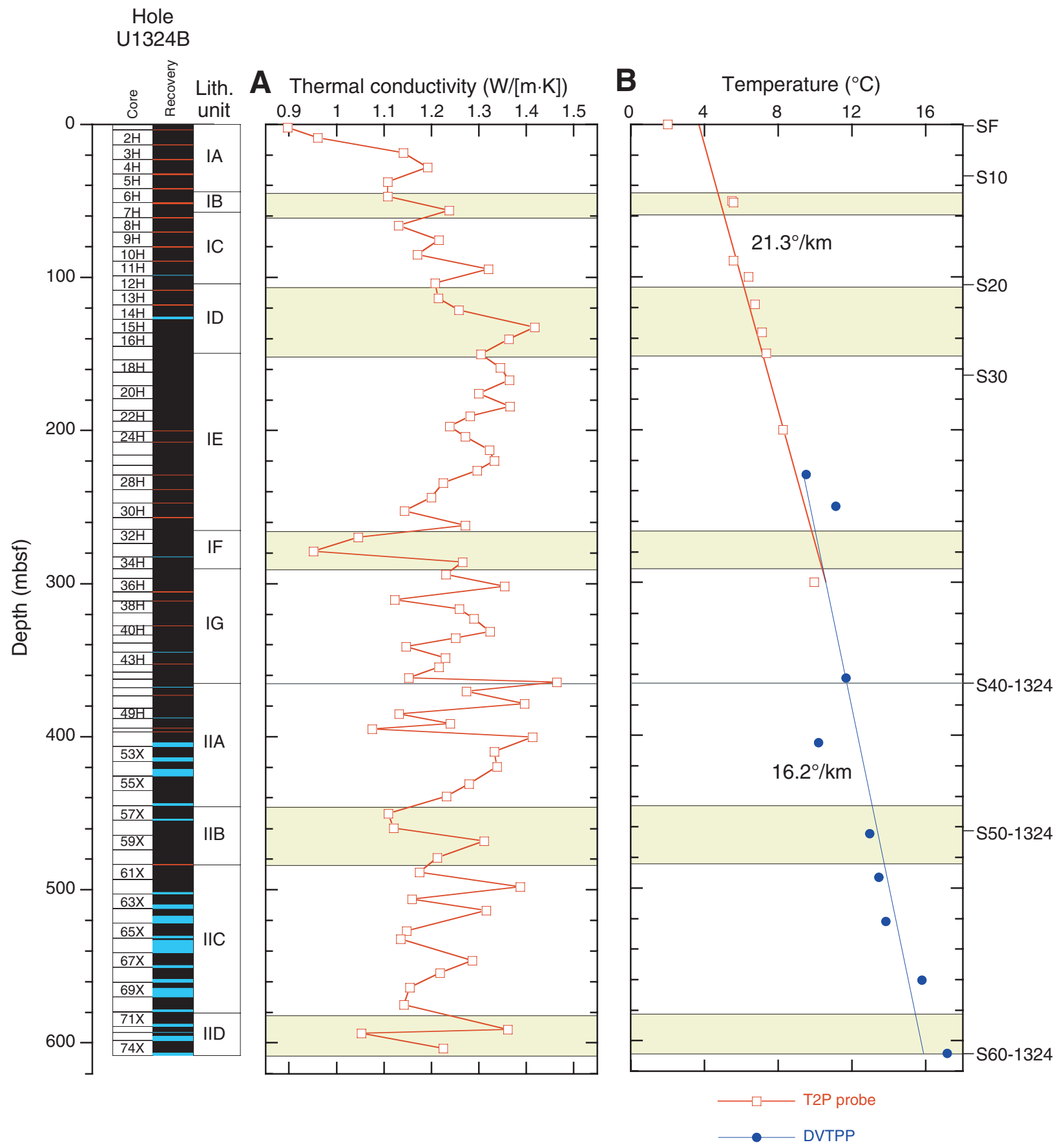


Figure F38. A. $P$-wave velocity vs. depth. B. $P$-wave anisotropy vs. depth, with seismic reflectors $(\mathrm{SF}=$ seafloor). Yellow $=$ mass transport deposits. $\mathrm{PWL}=P$-wave logger on the MST, $\mathrm{PWS}=$ contact probe system, $\mathrm{WL}=$ wireline logging.

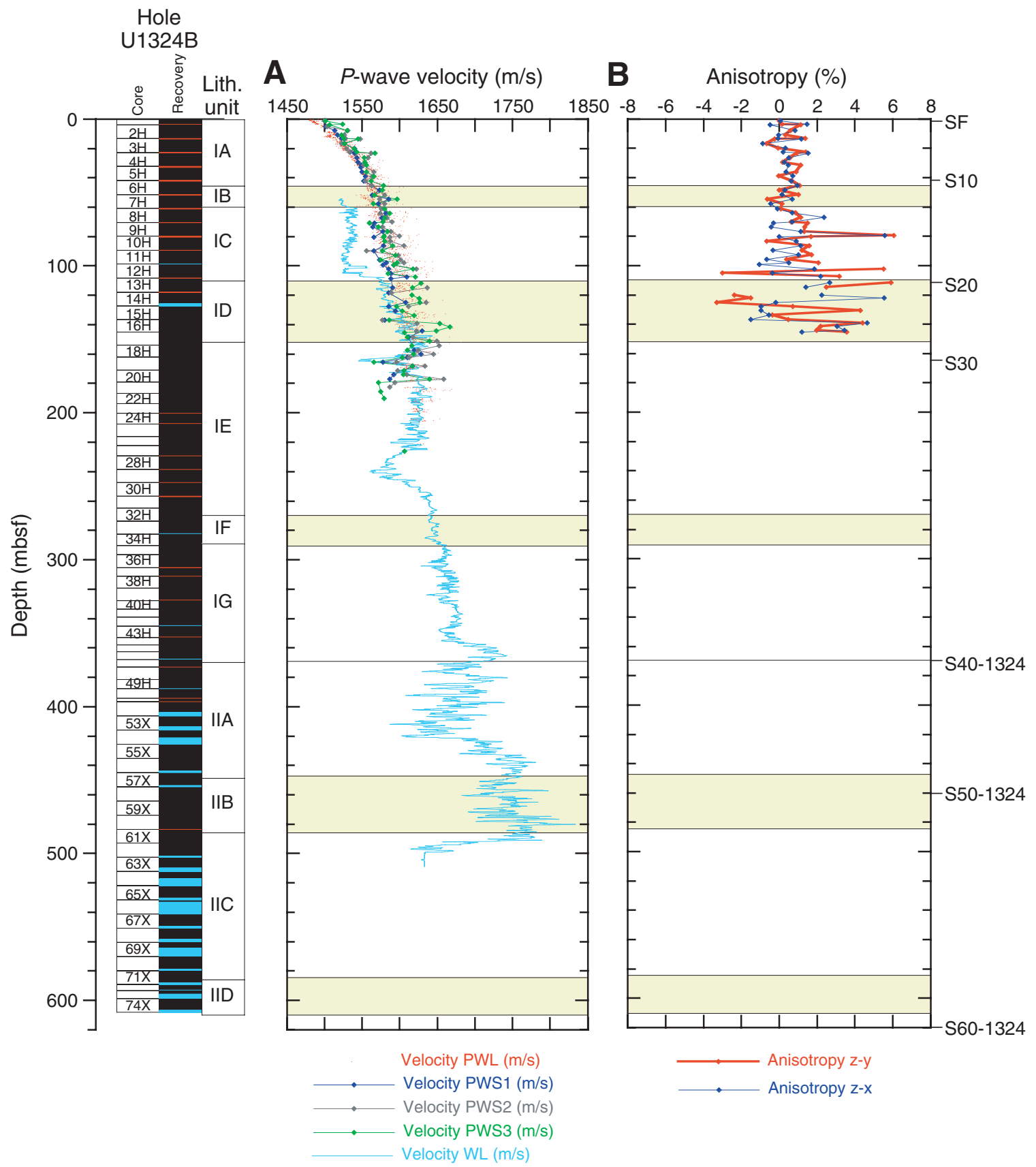


Figure F39. A. Peak and residual undrained shear strength from vane shear tests. B. Comparison of the peak undrained shear strengths measured by the shear vane and the pocket penetrometer. C. Sensitivity. Seismic reflectors (SF = seafloor; see "Background and objectives") are shown. Yellow $=$ mass transport deposits.

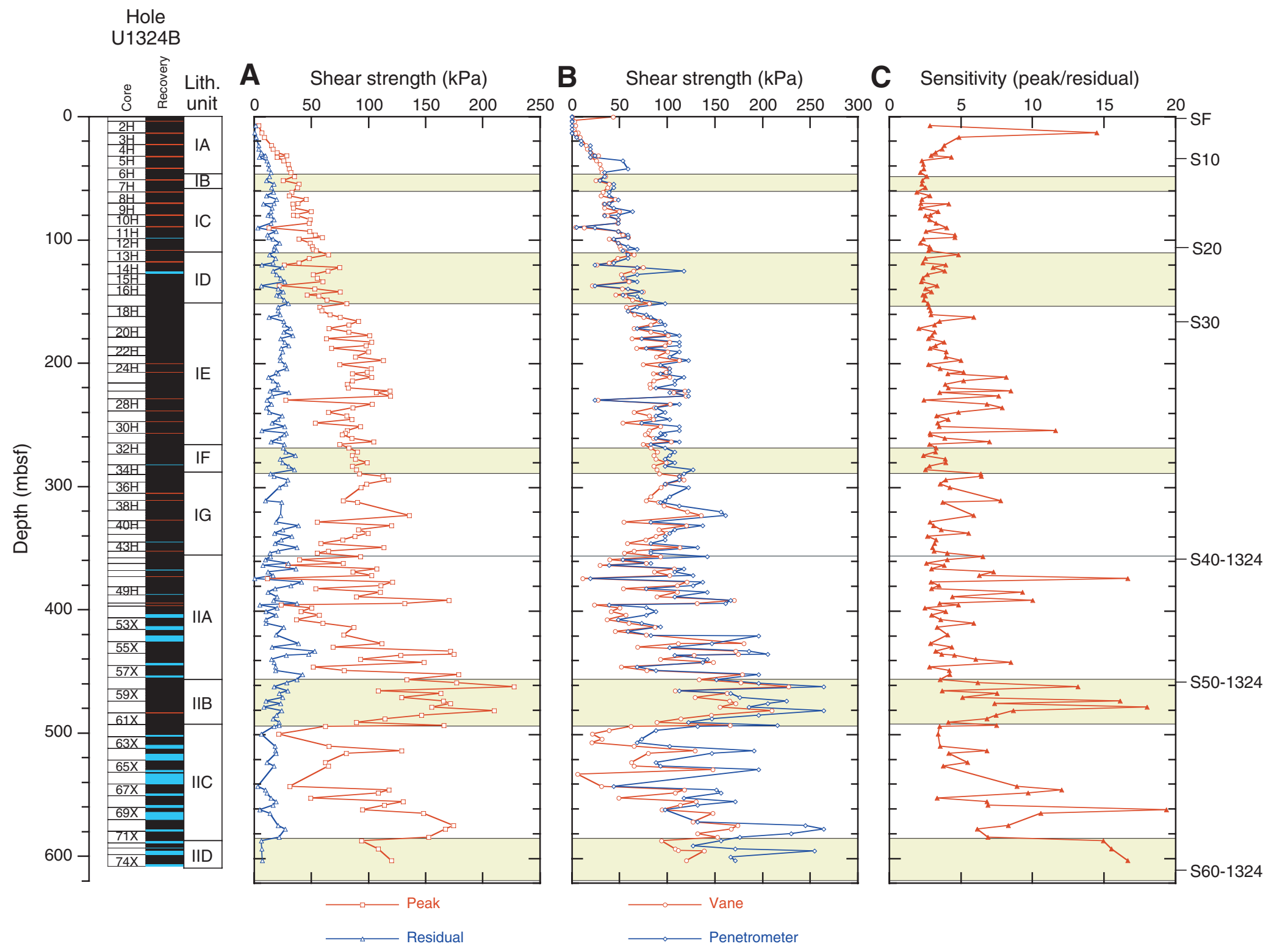


Figure F40. A. Comparison between the undrained peak shear strength and the ratio between the peak shear strength $\left(\tau_{\mathrm{fu}}^{\text {peak }}\right)$ and the vertical hydrostatic effective stress $\left(\sigma_{\mathrm{vh}}{ }^{\prime}\right)$. B. Lithostatic stress and vertical hydrostatic effective stress calculated from LWD (IDRO) bulk density profile (see "Physical properties" in the "Methods" chapter). Seismic reflectors ( $\mathrm{SF}=$ seafloor) are shown.

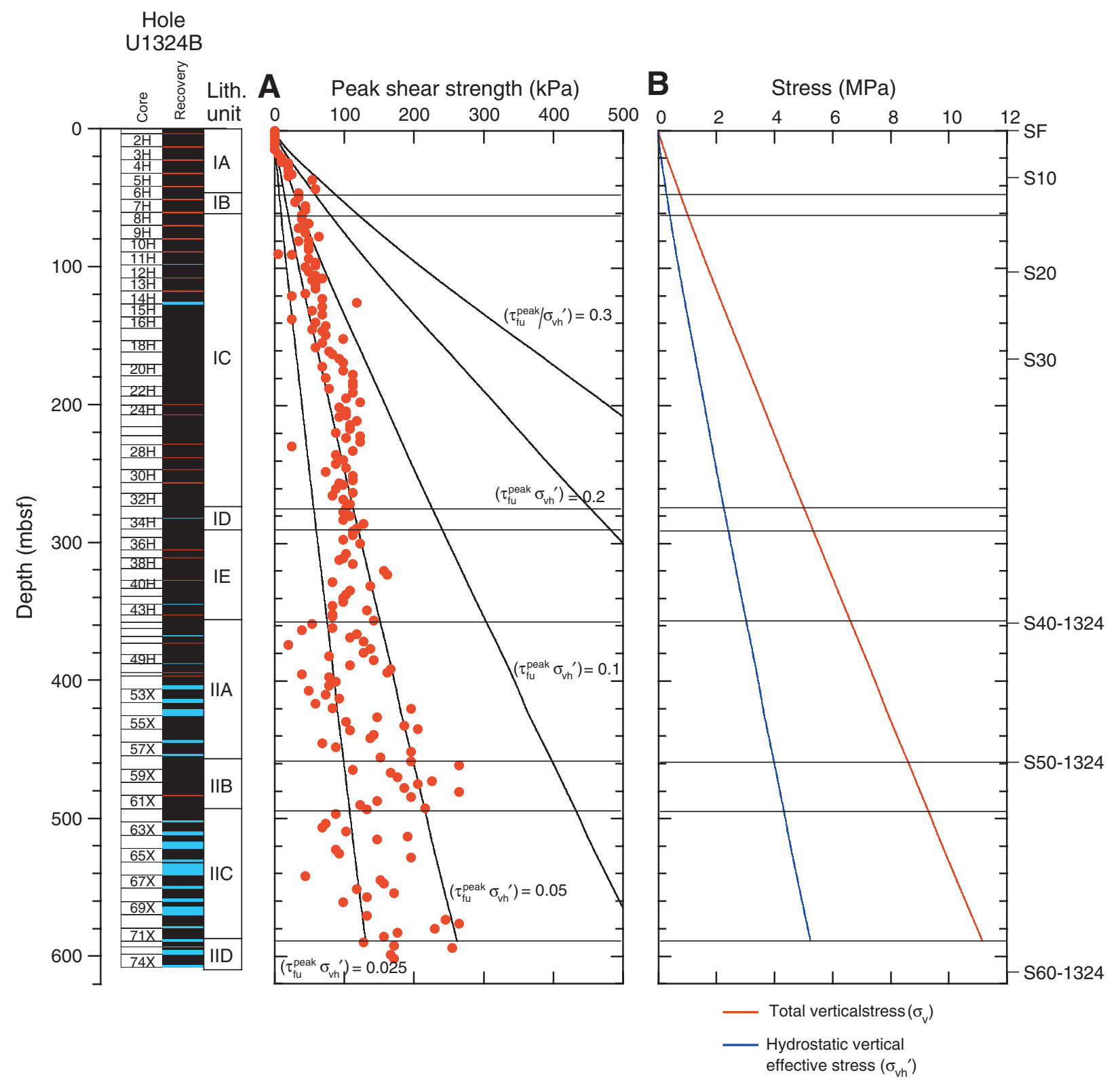


Figure F41. Data quality of curves for LWD/MWD measurements from Hole U1324B showing the rate of penetration (ROP), density-derived caliper, and bulk density correction.
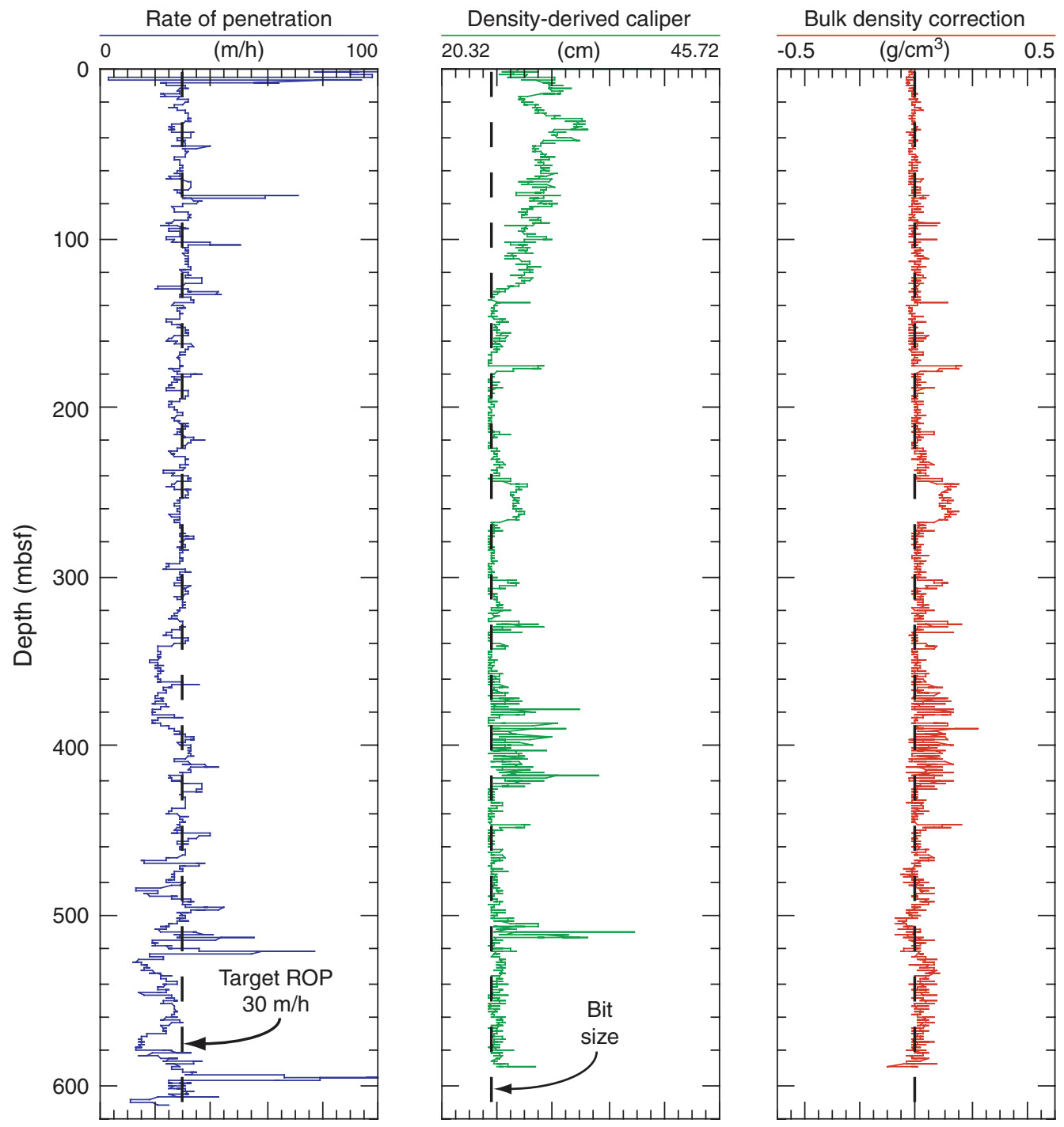
Figure F42. Pressure monitoring of Hole U1324A along with seismic reflectors ( $\mathrm{SF}=$ seafloor), gamma radiation (GR), and lithostratigraphic units. The near-linear increase in annular pressure whole drilling (APWD) is interpreted as stable borehole conditions without shallow-water flow problems. Variations in annular overpressure in excess of hydrostatic $\left(\mathrm{APWD}^{*}\right)$ and equivalent circulating density referenced to seafloor $\left(\mathrm{ECD}_{\mathrm{rsf}}\right)$ at 470-608 mbsf are due to continuous circulation of 10 ppg mud (seawater, sepiolite, and barite).

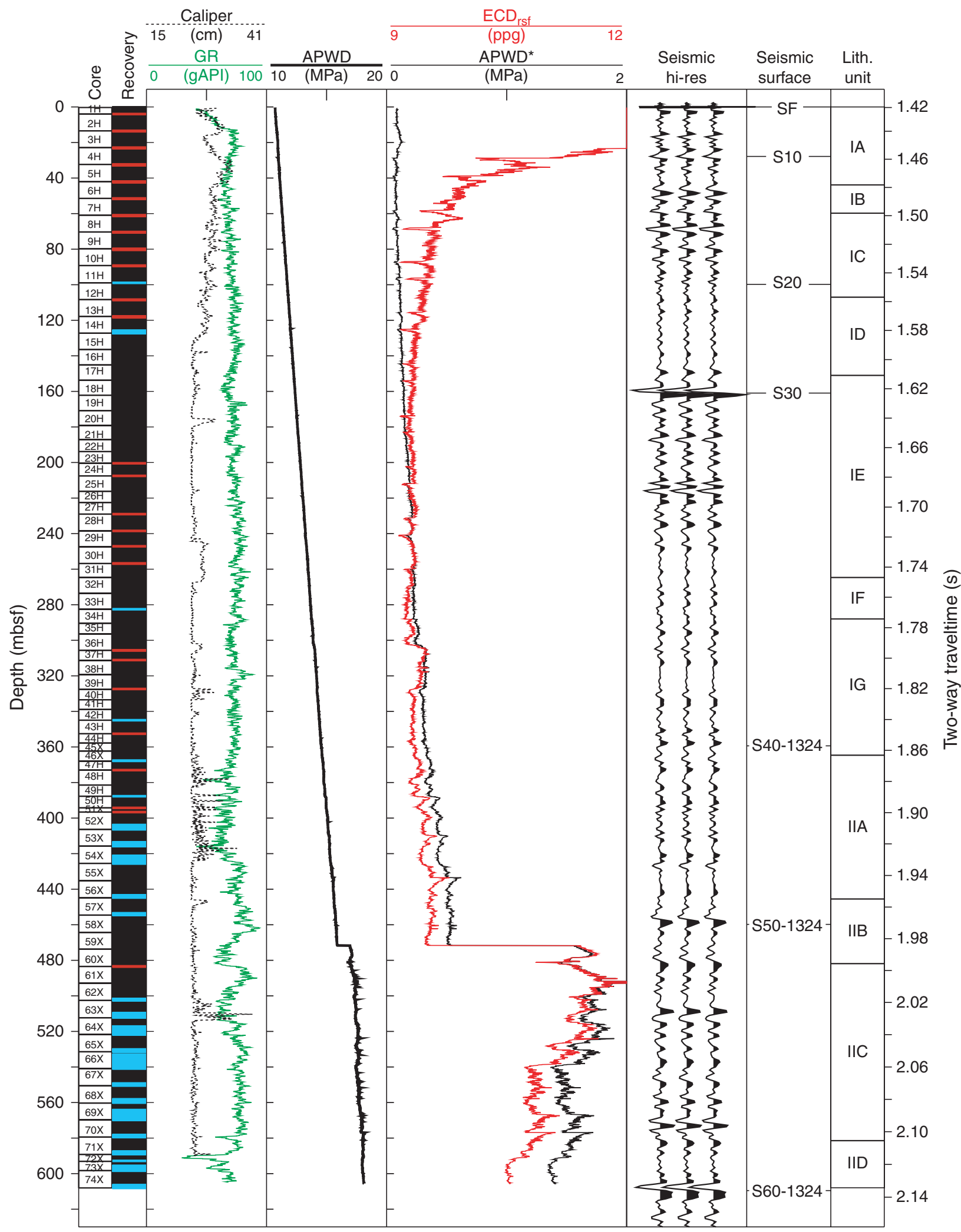


Figure F43. LWD logs recorded in Hole U1324A. Density caliper, photoelectric factor (PEF), and neutron porosity were recorded with the Vision Density Neutron (VDN) tool. Gamma ray and resistivity measurements were obtained with the GeoVision Resistivity (GVR) tool. The red line superimposed on the (PEF) log is a five-point average curve. The lithologic column is based on core descriptions made from Holes U1324B and U1324C. Lithostratigraphic subunit boundaries are denoted with dashed lines. Seismic reflectors $(S F=$ seafloor $)$ are shown. Both laboratory measurements of porosity and density (MAD) are compared to the neutron porosity data.

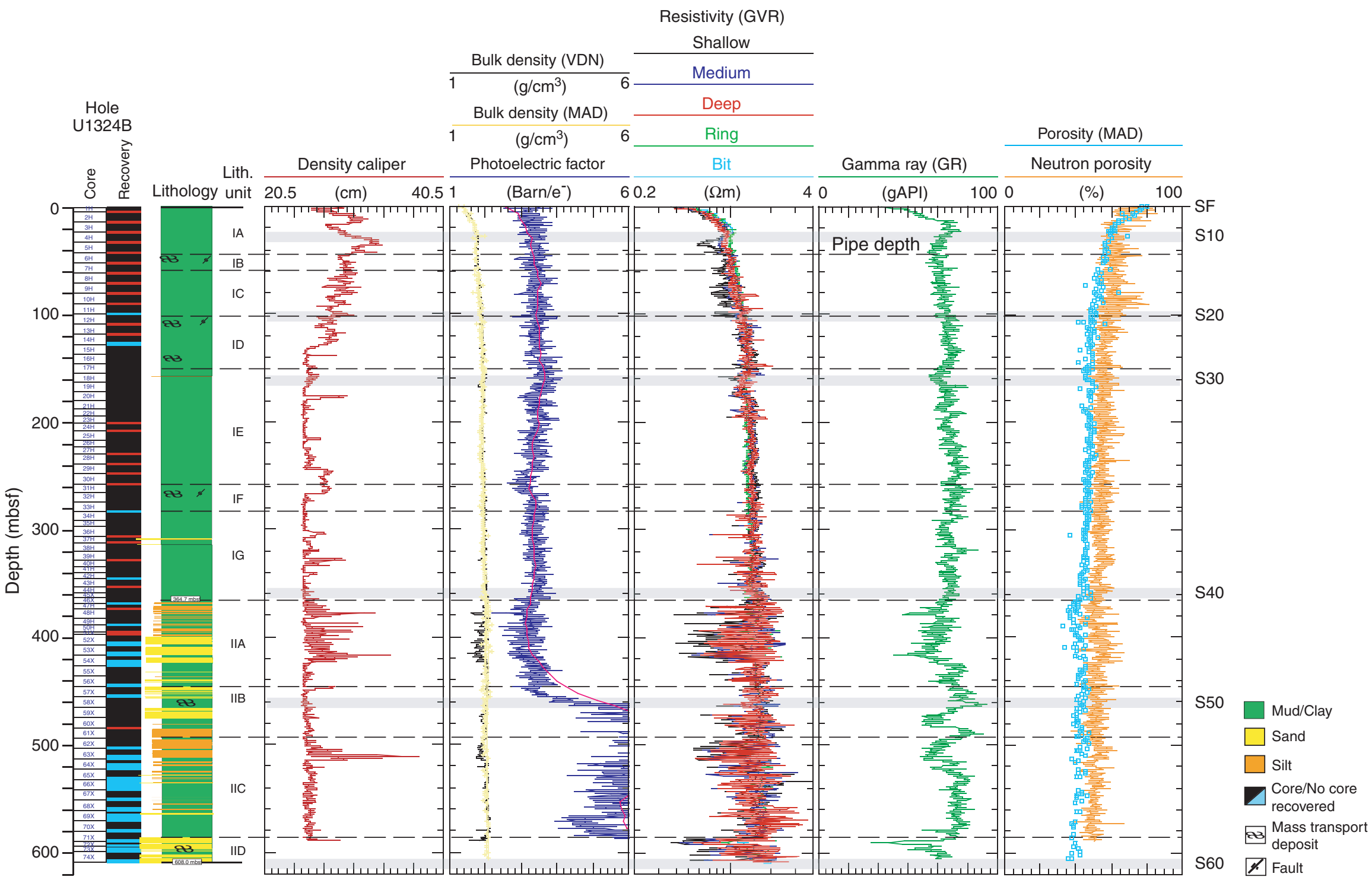


Figure F44. Resistivity images showing numerous deformed and dipping beds throughout Subunits ID and IE. Dips range from $5^{\circ}$ to $55^{\circ}$ and the top of Subunit IE correlates with seismic Reflector S30. RAB $=$ resistivity at the bit. GVR = GeoVision Resistivity, VDN = Vision Density Neutron.

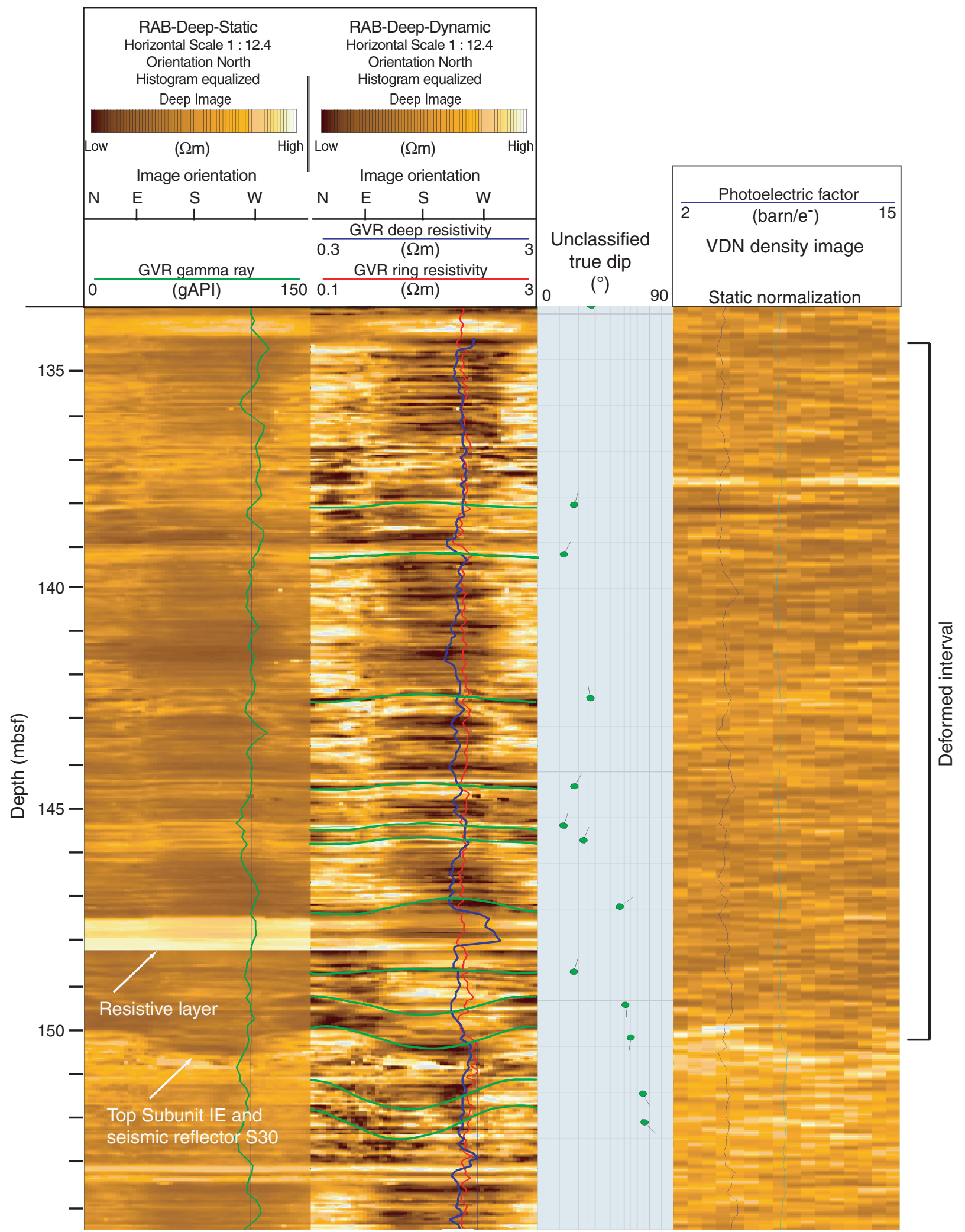


Figure F45. Resistivity images showing evidence of mass transport deposits in lithostratigraphic Subunit IIA and the presence of overturned beds. A series of cyclic intervals are interpreted as a succession of sand-siltmud laminae. $\mathrm{RAB}=$ resistivity at the bit. GVR = GeoVision Resistivity, VDN = Vision Density Neutron.

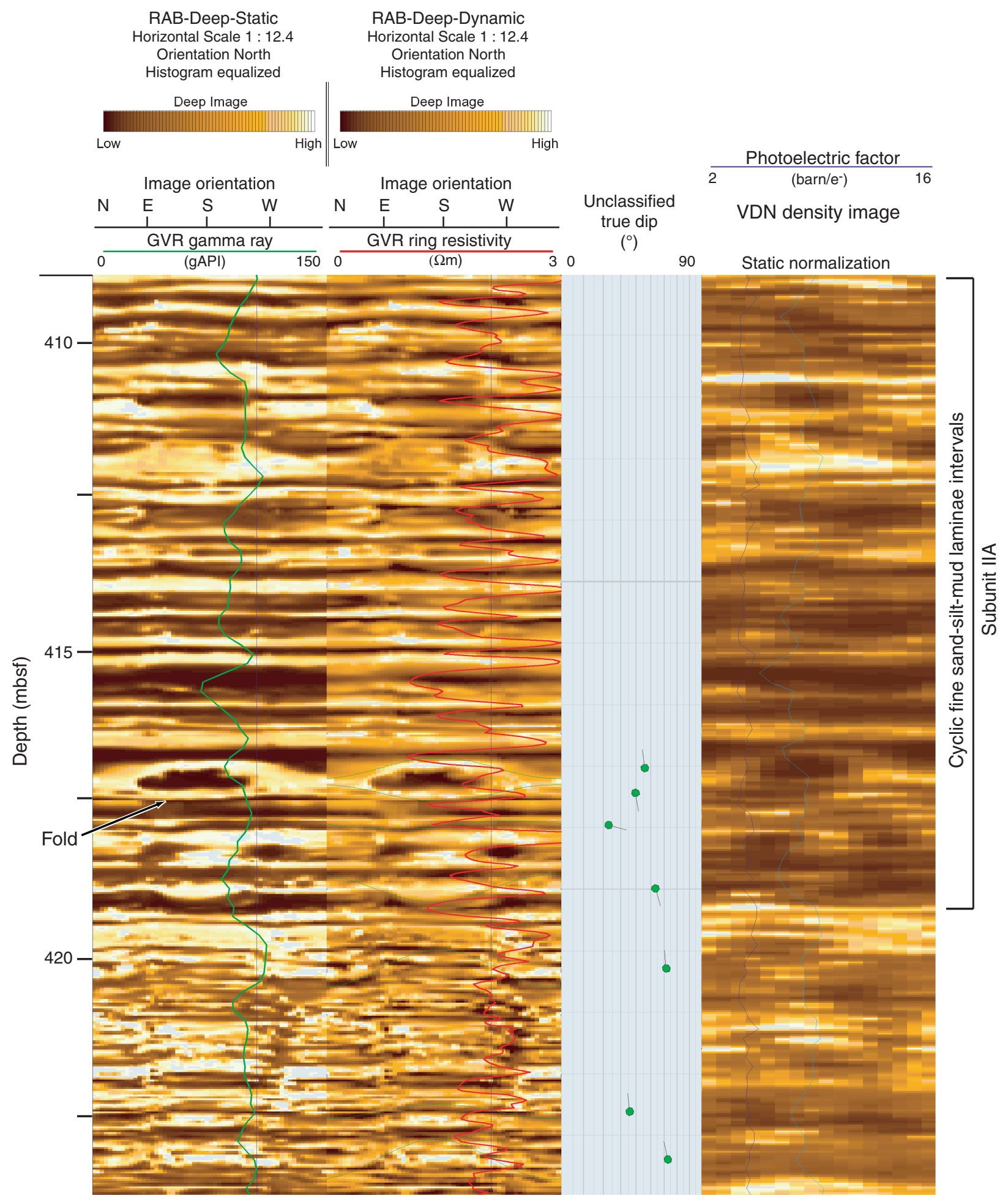


Figure F46. Resistivity images showing scoured surfaces in lithostratigraphic Subunit IIC, suggesting erosion. $\mathrm{RAB}=$ resistivity at the bit. GVR = GeoVision Resistivity, VDN = Vision Density Neutron.

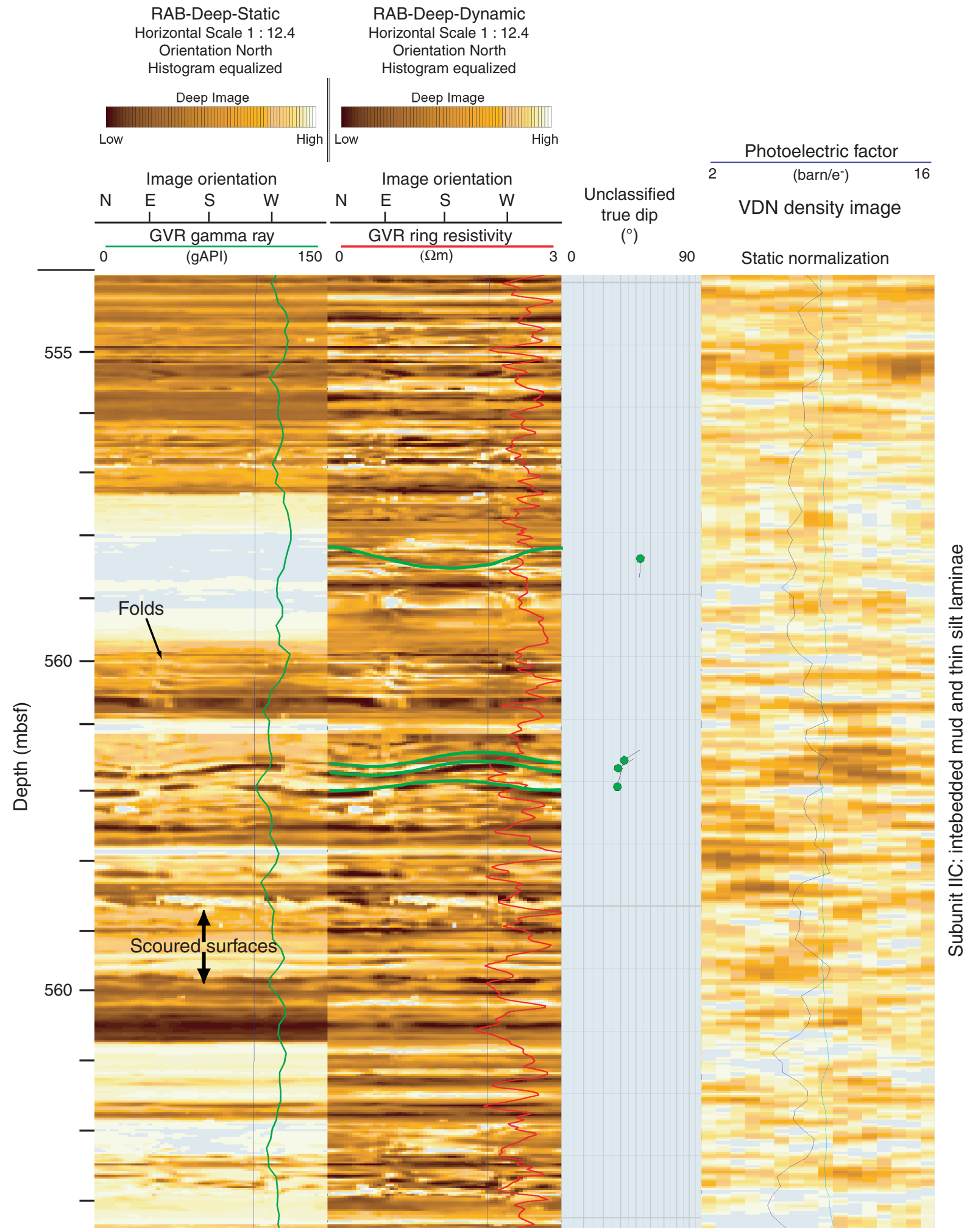


Figure F47. Resistivity images showing a fold with an east-west-trending fold axis within lithostratigraphic Subunit IID. Fold is overturned to the south, indicating mass transport in that direction. Most of the deformation features observed in Hole U1324A trend in an east-west direction with the majority dipping to the north. $\mathrm{RAB}=$ resistivity at the bit. GVR = GeoVision Resistivity.

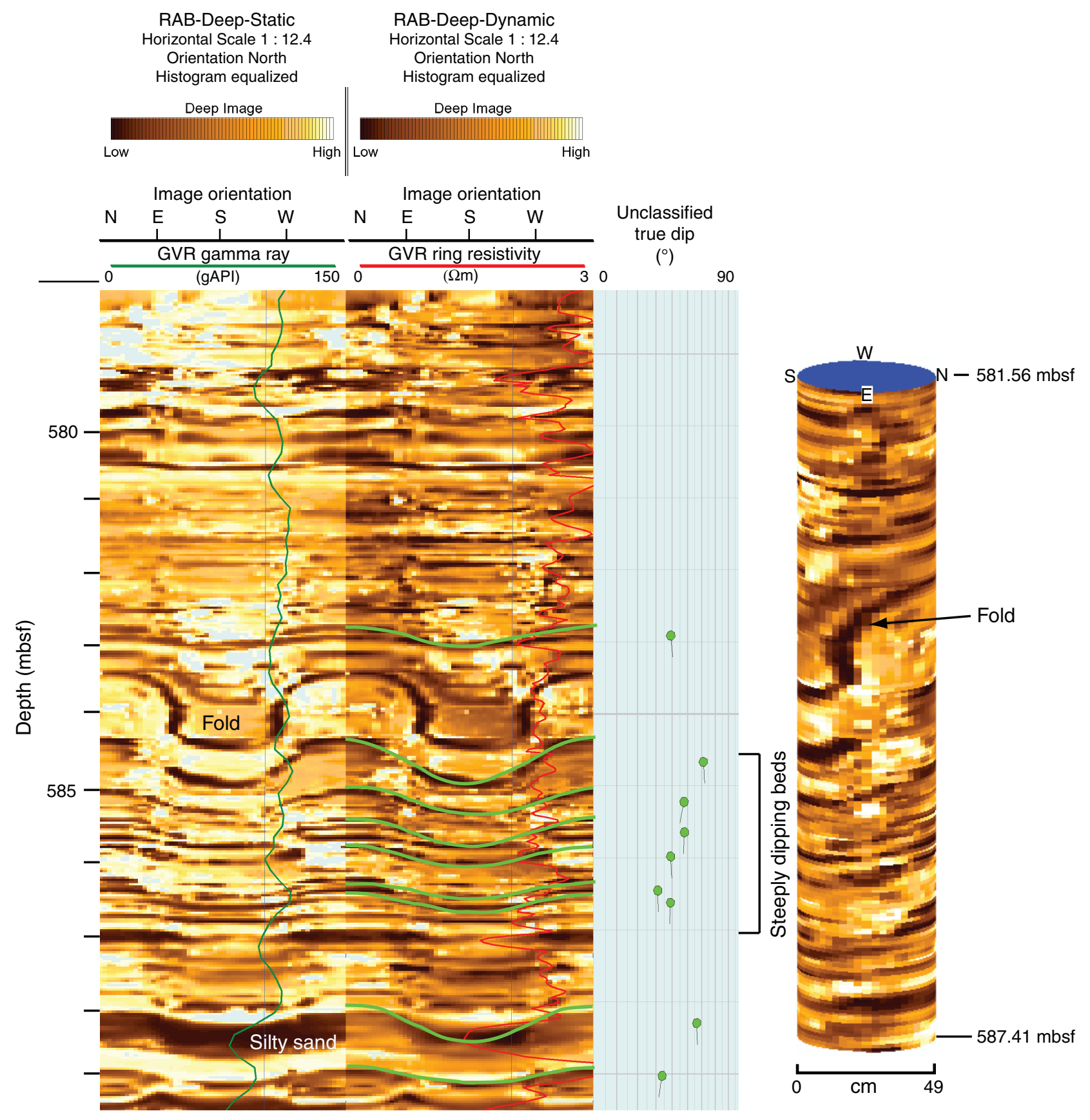


Figure F48. Wireline logs recorded in Hole U1324A include compressional wave velocity ( $P$-wave velocity), gamma ray including spectral components, and interval velocities derived from check shots. The density caliper from LWD measurements is presented to show the quality of the borehole. Lithologic and core recovery columns are based on results from Hole U1324B. Seismic reflectors $(\mathrm{SF}=\mathrm{seafloor})$ are shown. VSP $=$ vertical seismic profile.

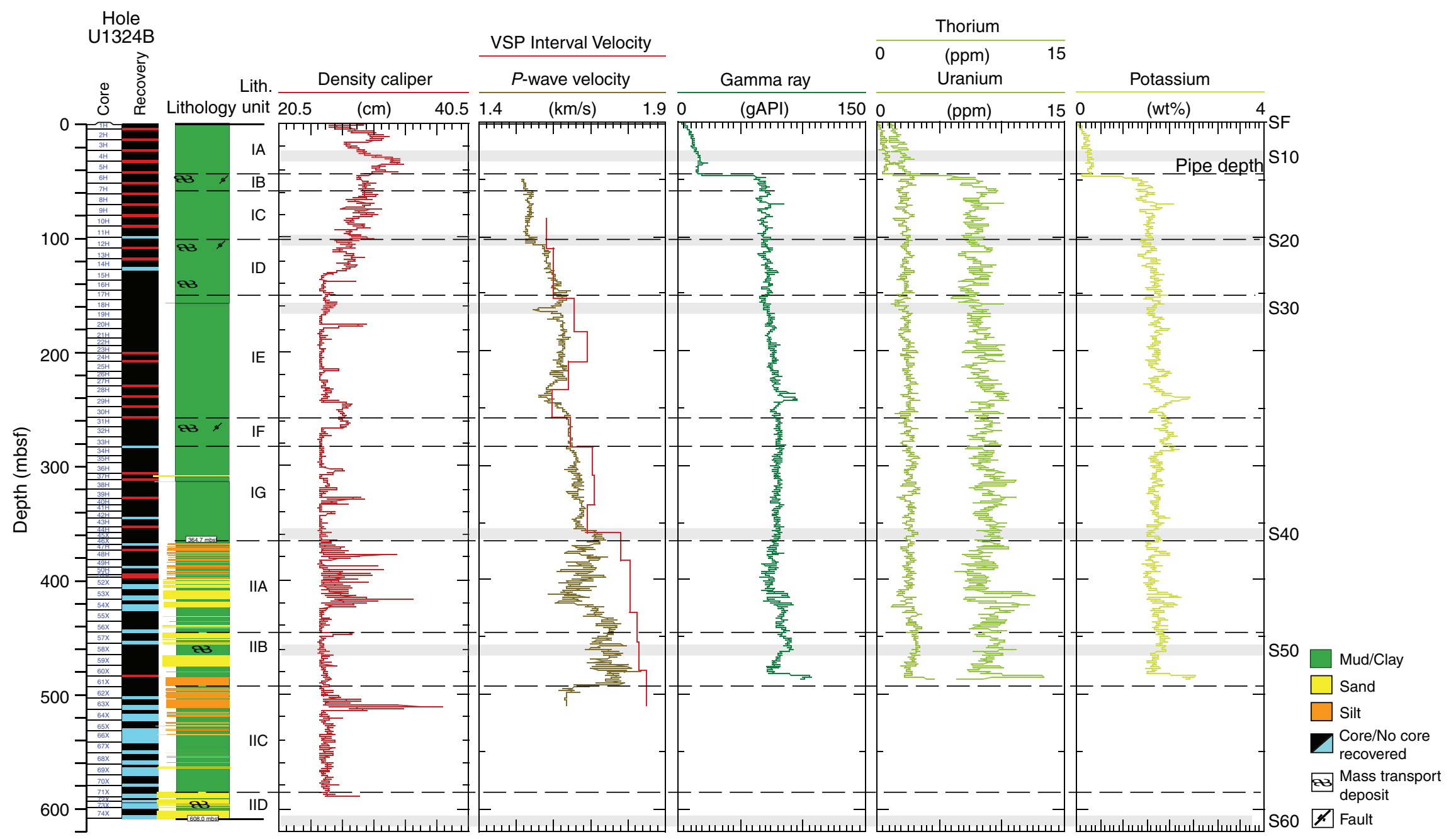


Figure F49. Calculated two-way traveltime (TWT) below seafloor vs. mbsf relationship for Hole U1324A including interval and sonic velocities. The function used for the conversion represents a polynomial fit (Equation E1 in the "Site U1322" chapter) through the nearby check shot data (see text for details). All data are referenced to seafloor assuming a velocity of $1490 \mathrm{~m} / \mathrm{s}$ through the water column.

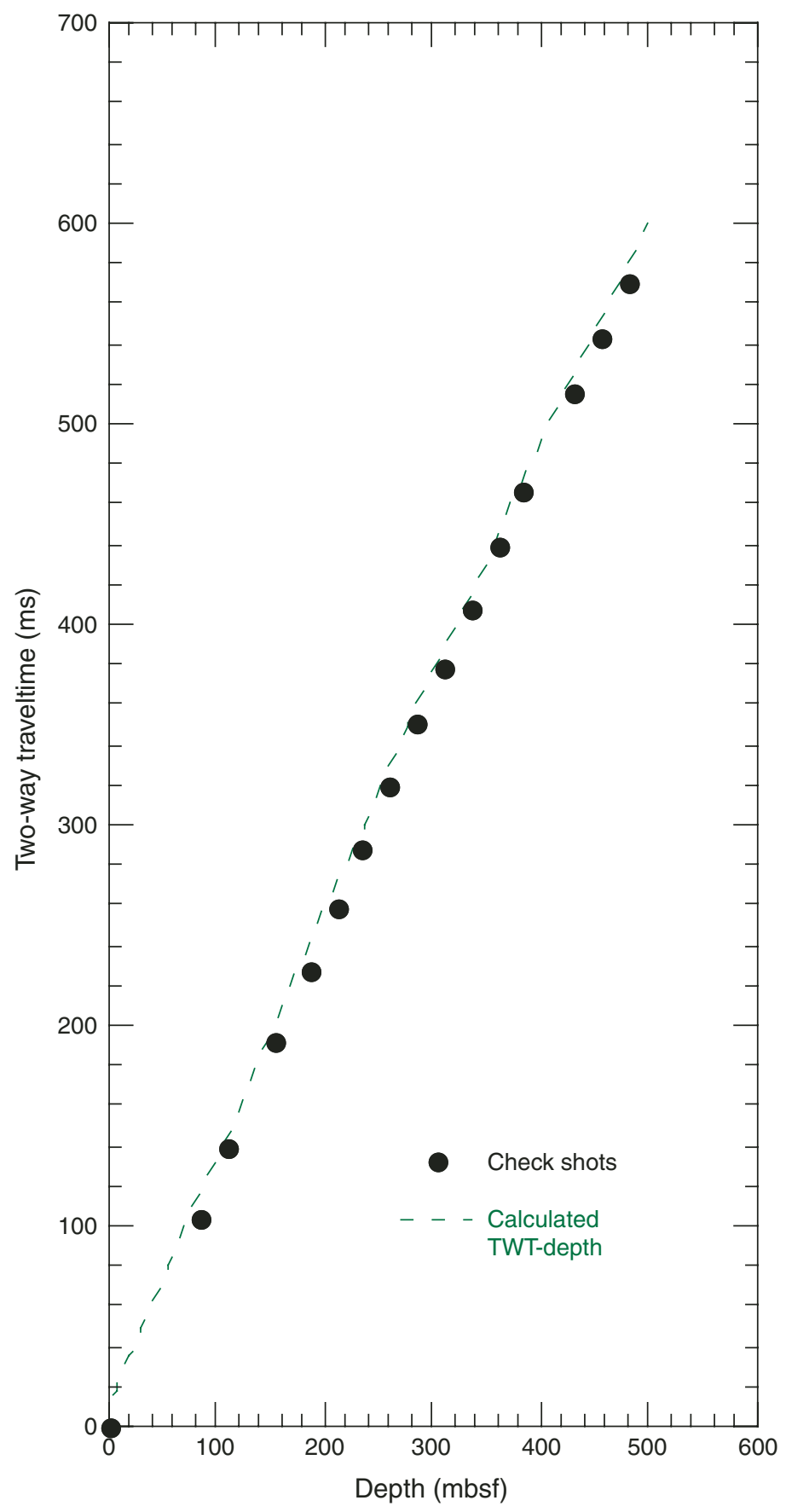


Figure F50. Core-log-seismic correlation for Site U1324. Synthetic seismogram was constructed by convolving a $150 \mathrm{~Hz}$ minimum-phase Ricker wavelet with the reflection coefficient series based on LWD bulk density and velocity log data. A seismic high-resolution trace (Hi-Res) is extracted from three-dimensional (3-D) high-resolution multichannel seismic (MCS) data at the location of Site U1324. GR = gamma ray, SF = seafloor.

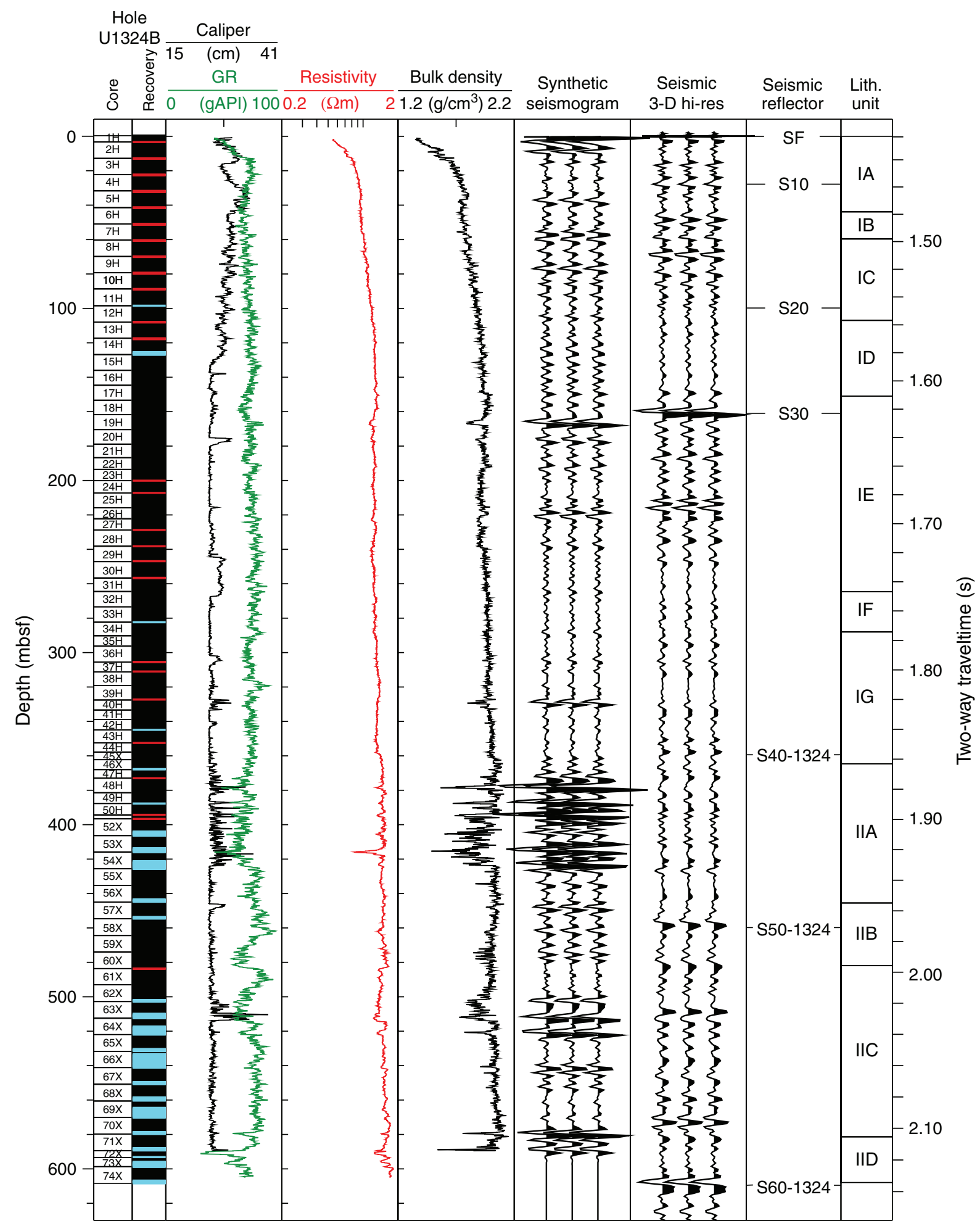


Figure F51. Logs from Hole U1324A used for the definition of low-relief channel deposits and changes in grain size with depth. Lithostratigraphic units and regional seismic reflectors ( $\mathrm{SF}=$ seafloor) are shown.

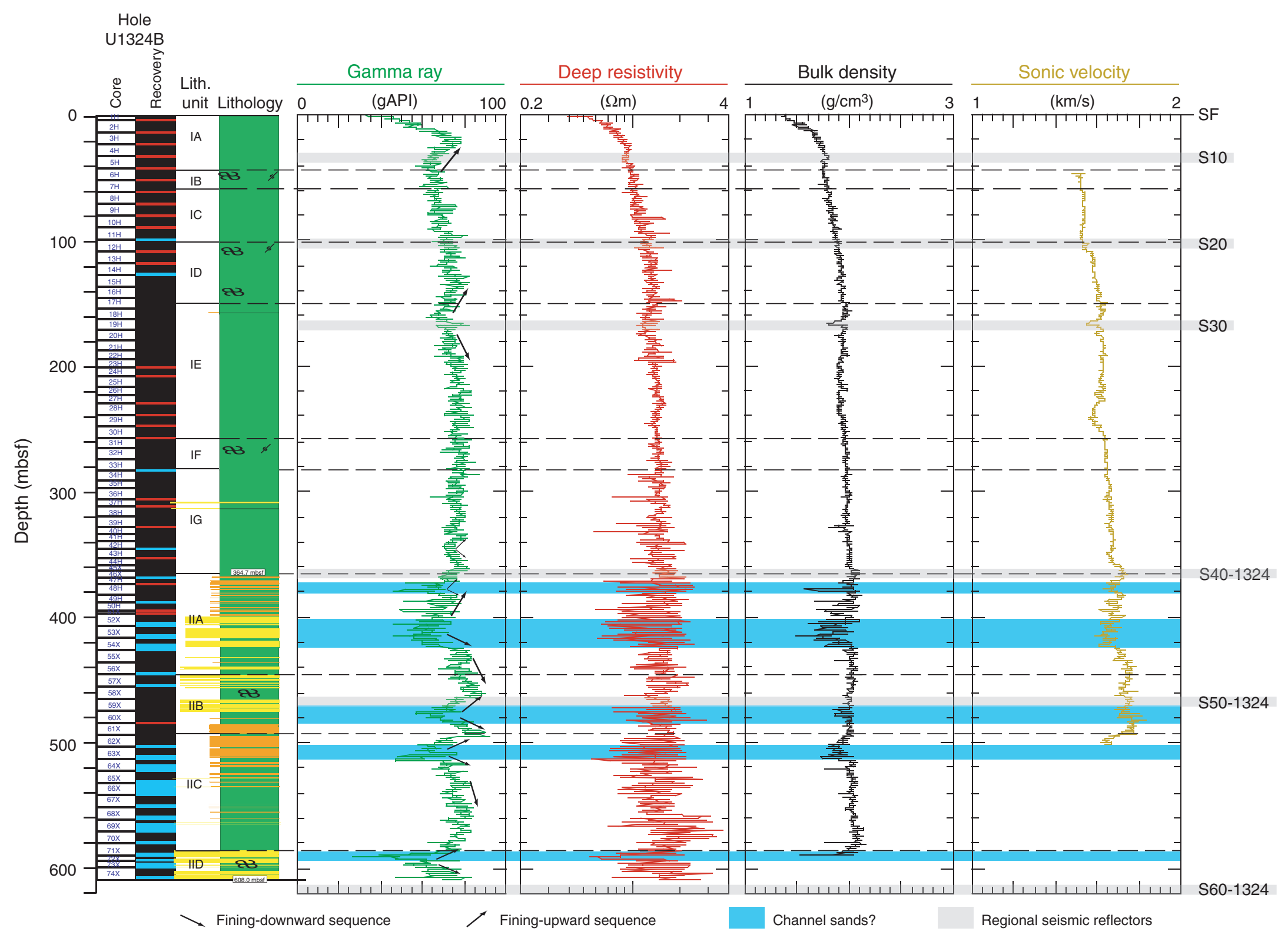


Figure F52. Result for the APCT tool deployment for Core 308-U1324B-6H (51.3 mbsf). Temperature was measured in the sediment for $10 \mathrm{~min}$ to establish the temperature decay curve (blue). Extrapolation from the dissipation curve provided an equilibrium temperature of $5.66^{\circ} \mathrm{C}$ (dashed line). See "Downhole" in "Supplementary material."

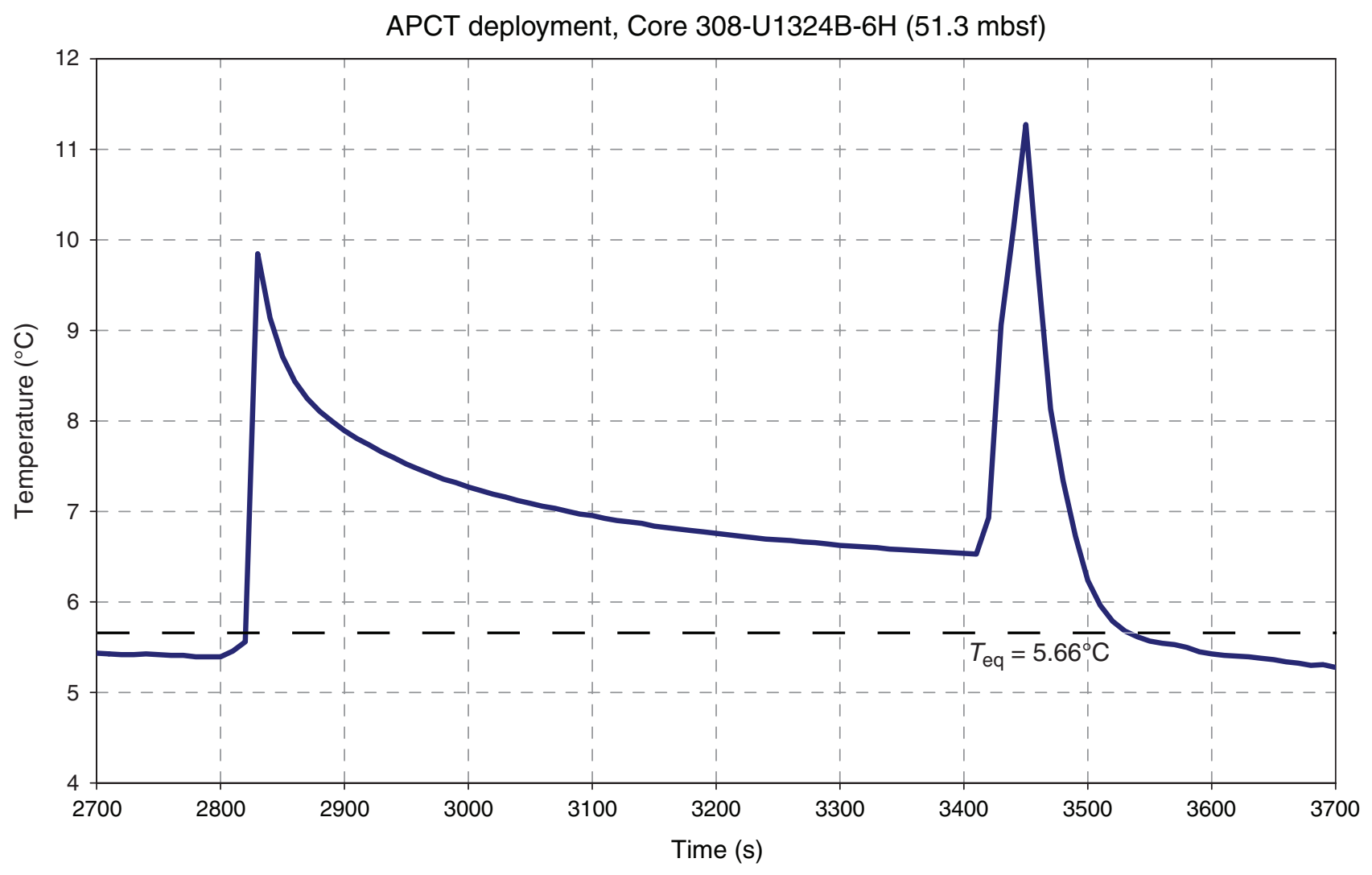


Figure F53. Result for the APCT tool deployment for Core 308-U1324B-9H (79.8 mbsf). Temperature was measured in the sediment for $10 \mathrm{~min}$ to establish the temperature decay curve (blue). Extrapolation from the dissipation curve provided an equilibrium temperature of $6.32^{\circ} \mathrm{C}$ (dashed line). See "Downhole" in "Supplementary material."

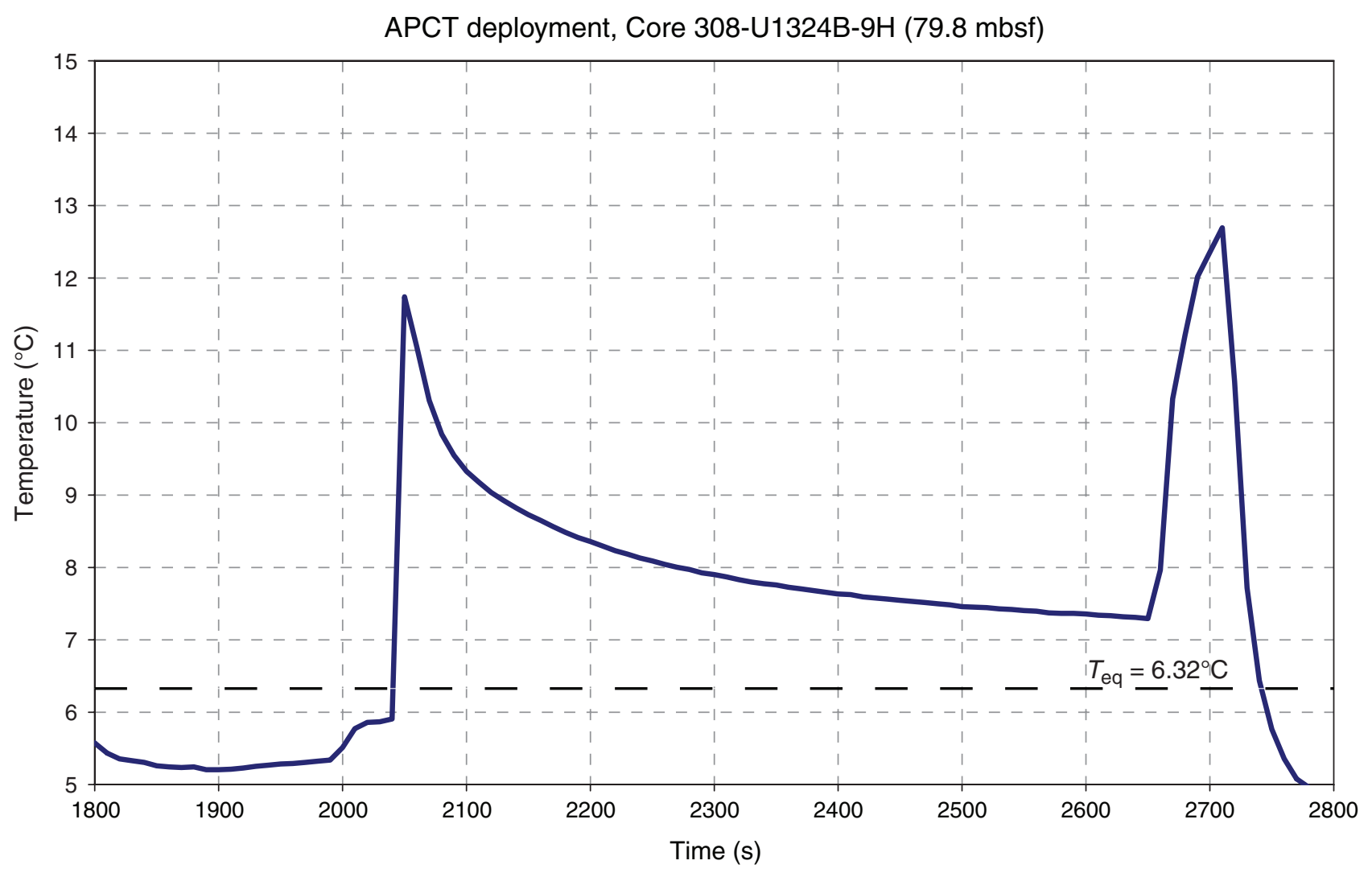


Figure F54. Result for the APCT tool deployment for Core 308-U1324B-12H (108.3 mbsf). Temperature was measured in the sediment for $10 \mathrm{~min}$ to establish the temperature decay curve (blue). Extrapolation from the dissipation curve provided an equilibrium temperature of $6.40^{\circ} \mathrm{C}$ (dashed line). See "Downhole" in "Supplementary material."

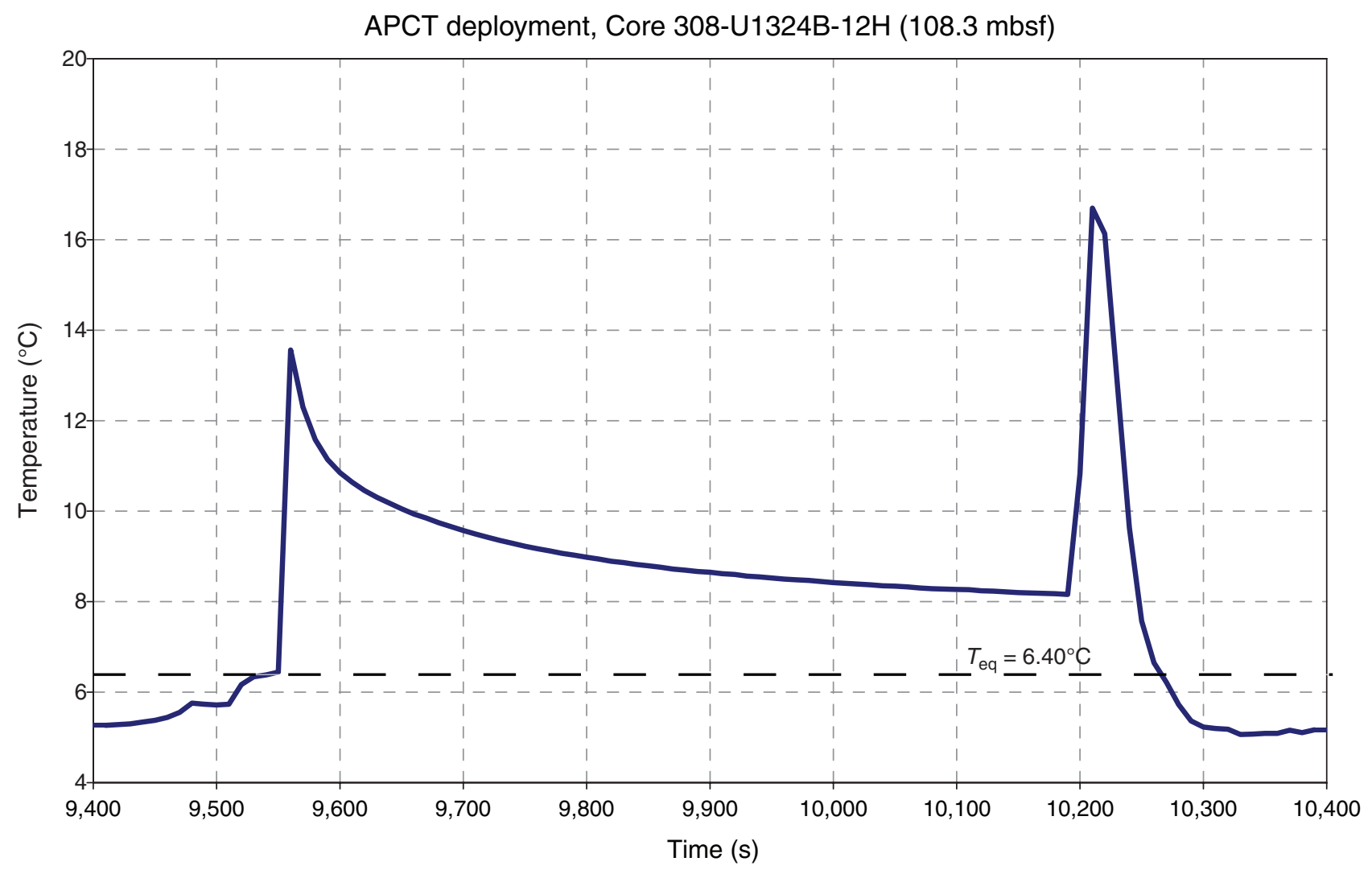


Figure F55. Result for the APCT tool deployment for Core 308-U1324B-15H (127.3 mbsf). Temperature was measured in the sediment for $10 \mathrm{~min}$ to establish the temperature decay curve (blue). Extrapolation from the dissipation curve provided an equilibrium temperature of $7.50^{\circ} \mathrm{C}$ (dashed line). See "Downhole" in "Supplementary material."

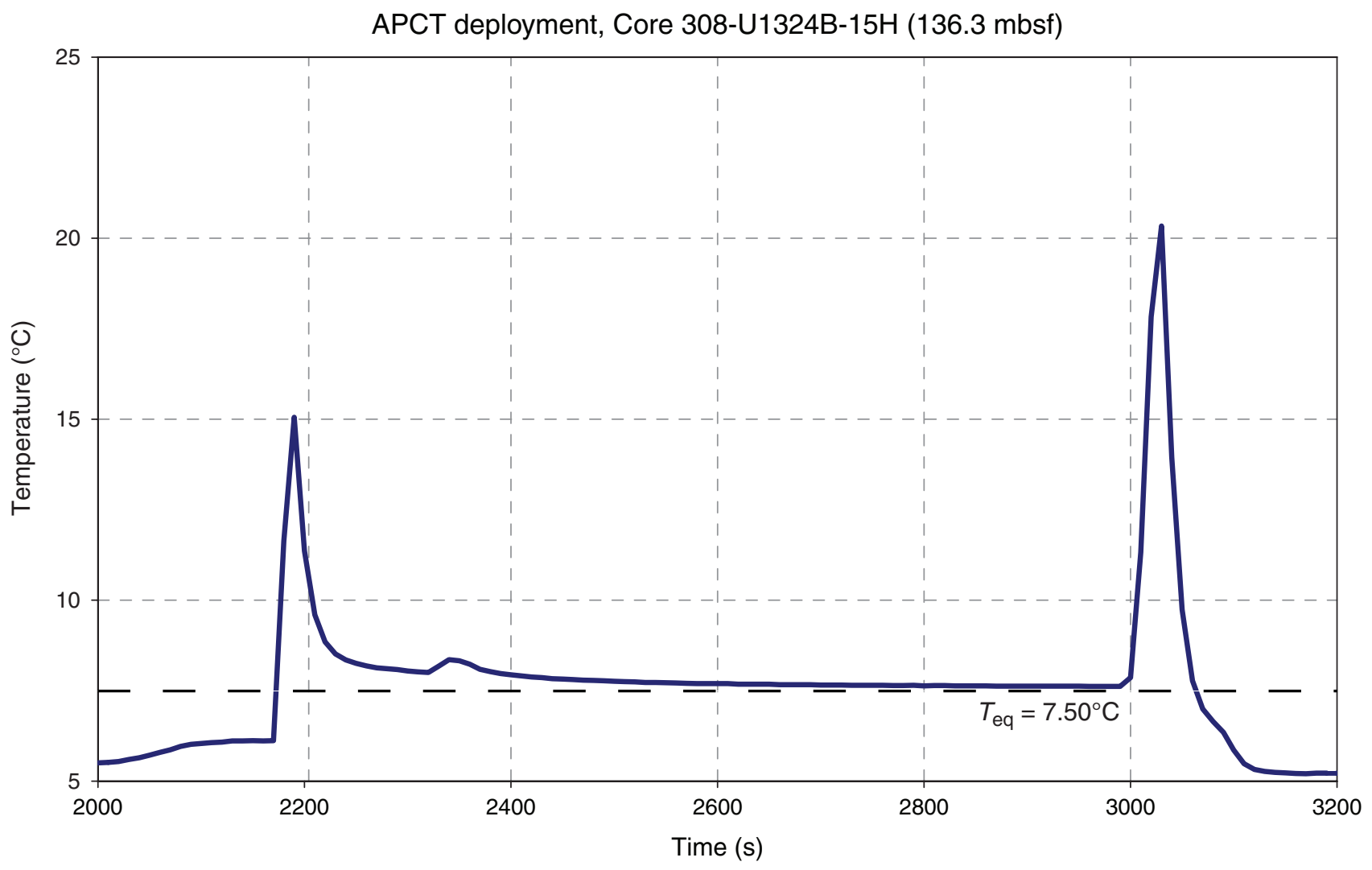


Figure F56. Fluid pressure and temperature measured by the temperature/dual pressure (T2P) probe during Deployment 5. CDT = central daylight time. See "Downhole" in "Supplementary material."

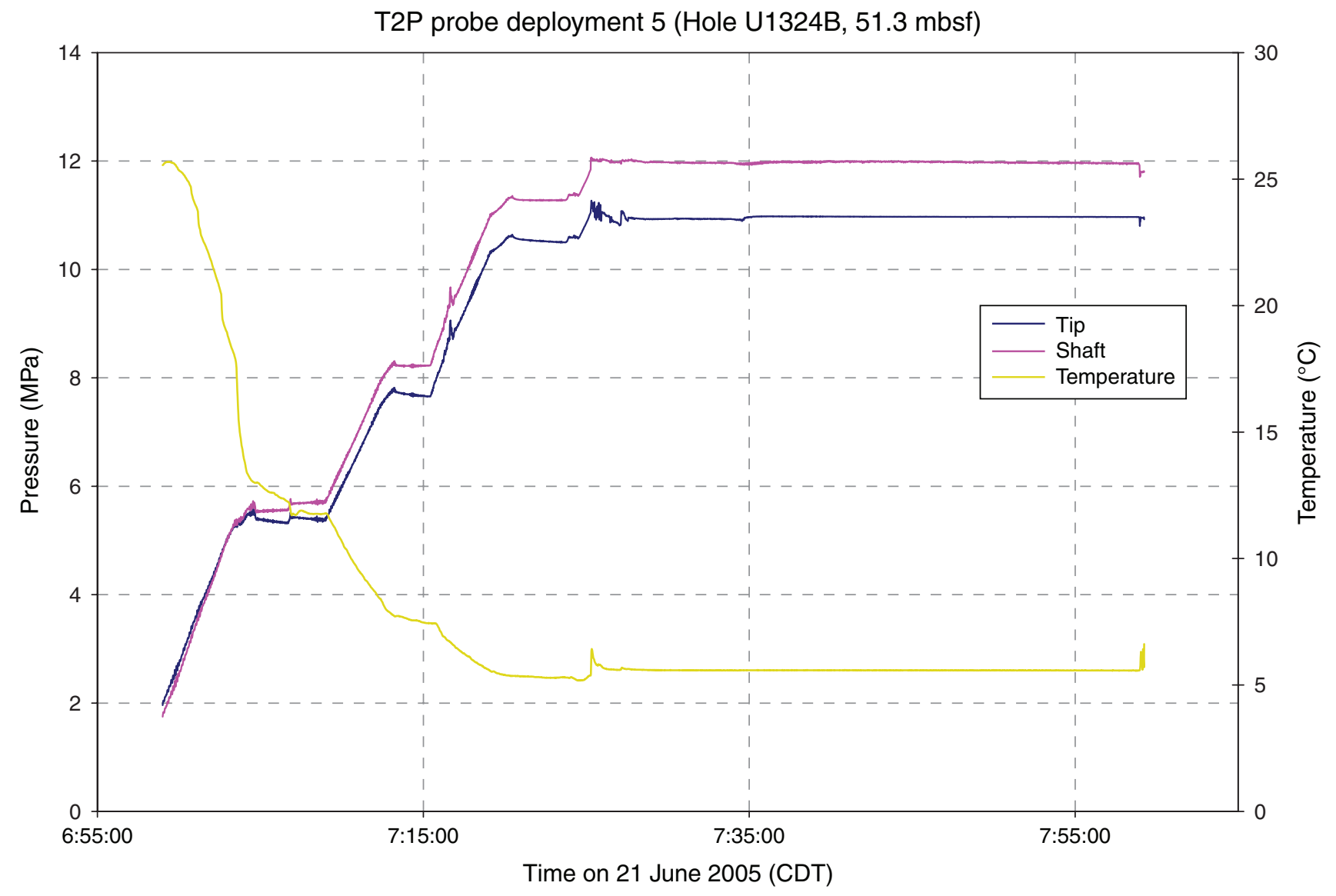


Figure F57. Fluid pressure and temperature measured by the temperature/dual pressure (T2P) probe during Deployment 6. CDT = central daylight time. See "Downhole" in "Supplementary material."

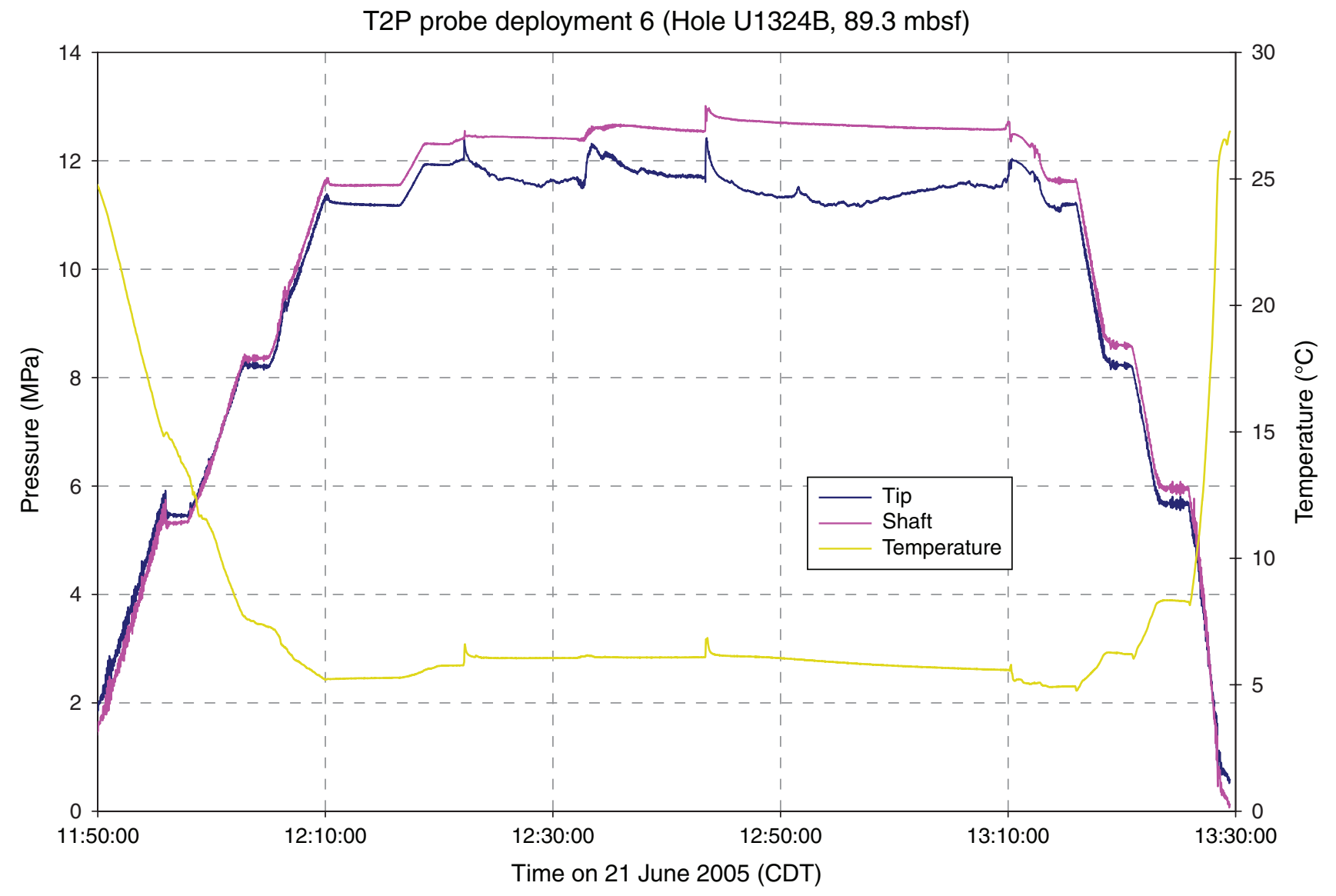


Figure F58. Fluid pressure and temperature measured by the temperature/dual pressure (T2P) probe during Deployment 7. CDT = central daylight time. See "Downhole" in "Supplementary material."

T2P probe deployment 7 (Hole U1324B, $117.8 \mathrm{mbsf}$ )

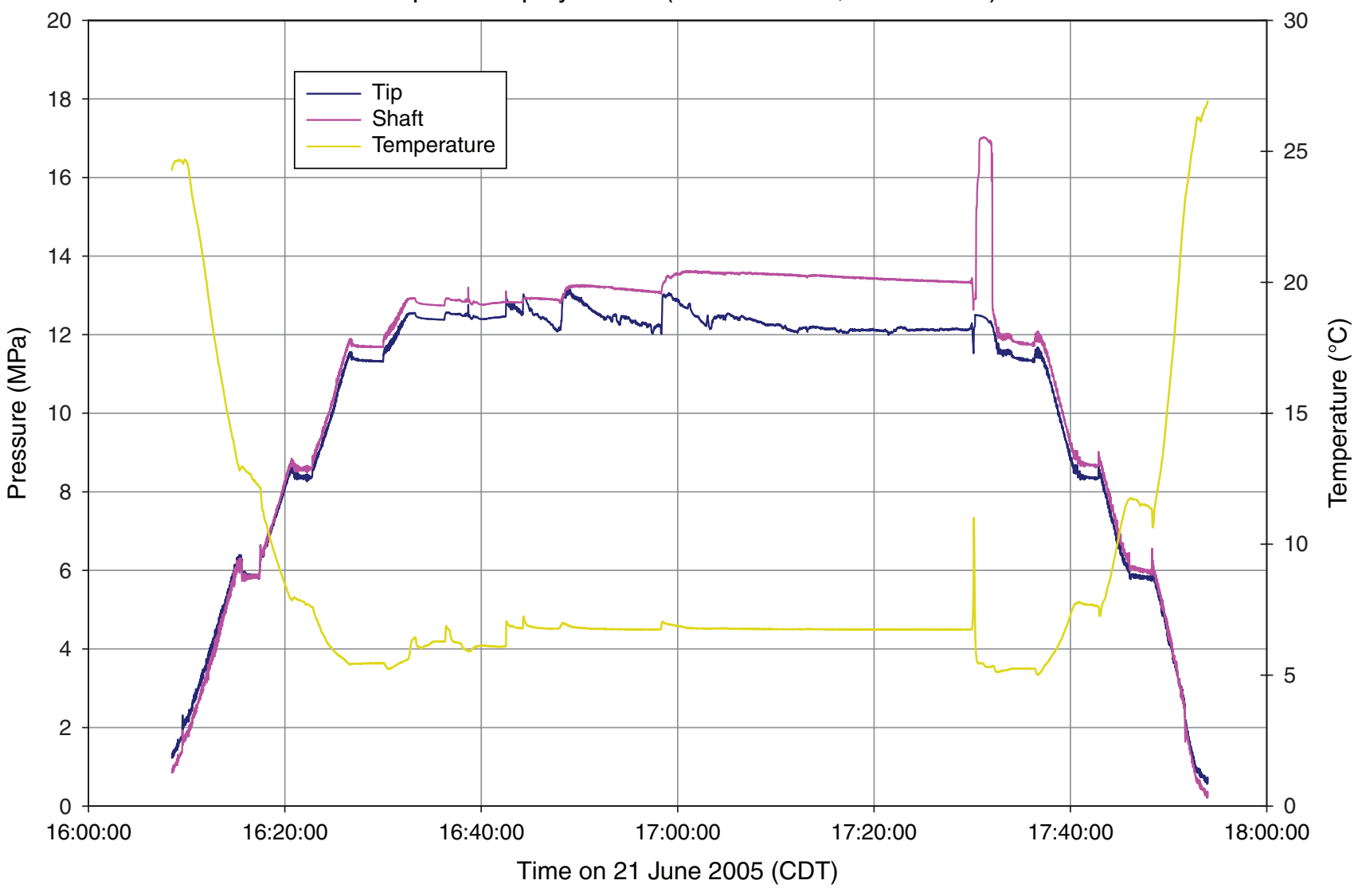


Figure F59. Fluid pressure and temperature measured by the temperature/dual pressure (T2P) probe during Deployment 8. CDT = central daylight time. See "Downhole" in "Supplementary material."

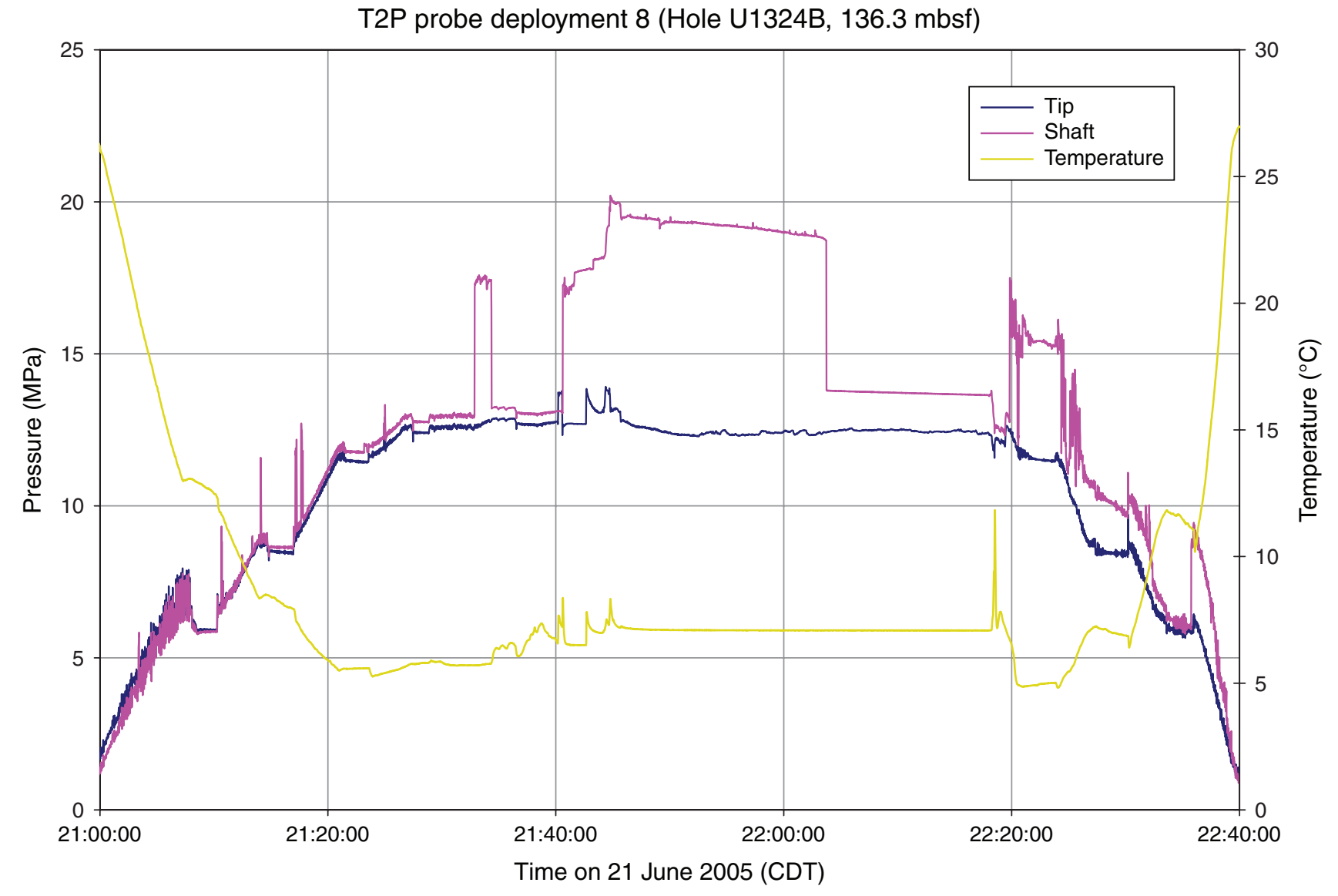


Figure F60. Fluid pressure and temperature measured by the temperature/dual pressure (T2P) probe during Deployment 9. CDT = central daylight time. See "Downhole" in "Supplementary material."

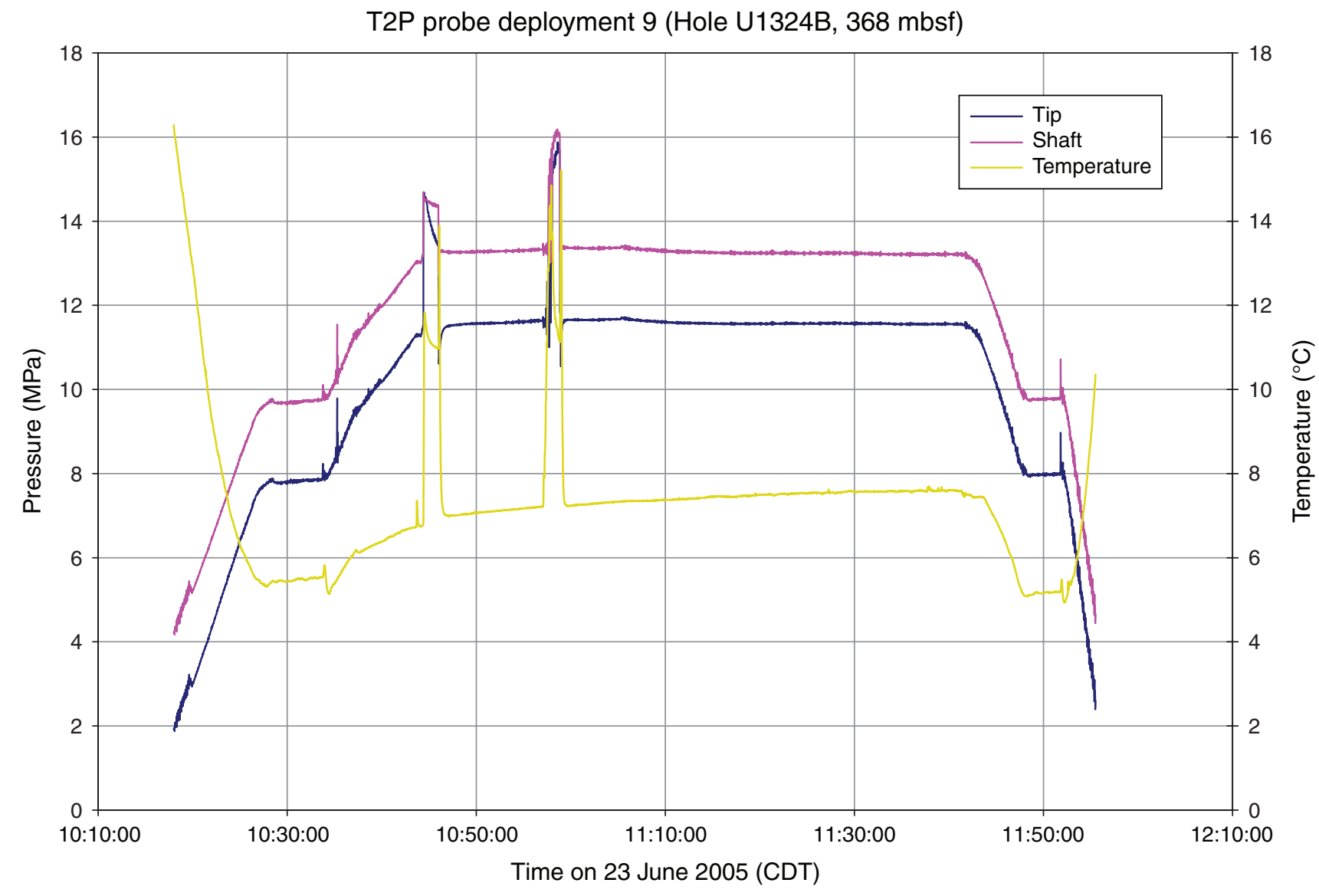


Figure F61. Fluid pressure and temperature measured by the temperature/dual pressure (T2P) probe during Deployment 11. CDT = central daylight time. See "Downhole" in "Supplementary material."

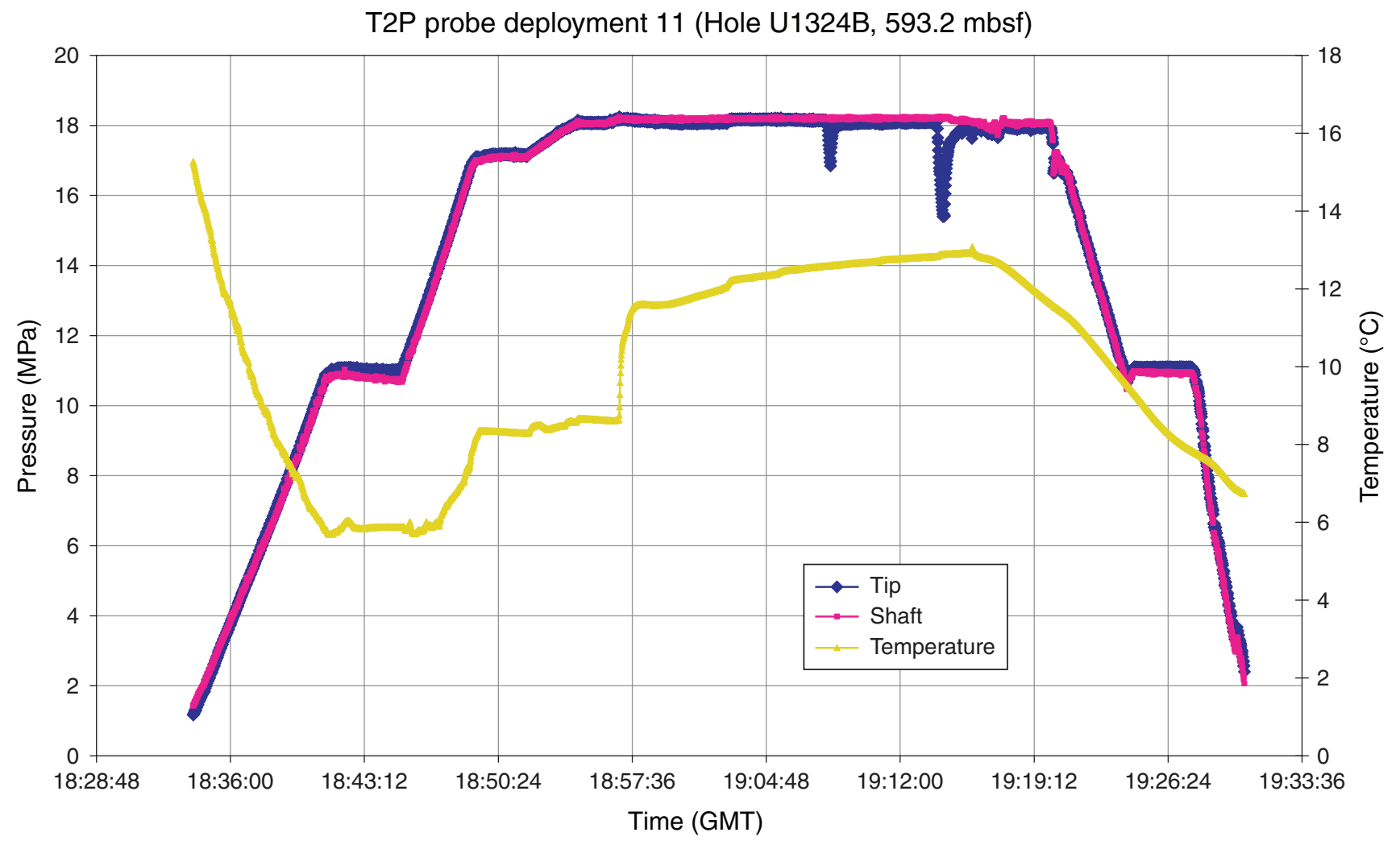


Figure F62. Fluid pressure and temperature measured by the temperature/dual pressure (T2P) probe Deployment 12 . Ph_500 $=$ hydrostatic pressure at $500 \mathrm{mbsl}, \mathrm{Ph} \_750=$ hydrostatic pressure at $75 \mathrm{mbsl}$, and Ph-mudline = hydrostatic pressure at seafloor. GMT = Greenwich Mean Time. See "Downhole" in "Supplementary material."

T2P probe deployment 12 (Hole U1324C, 50 mbsf)

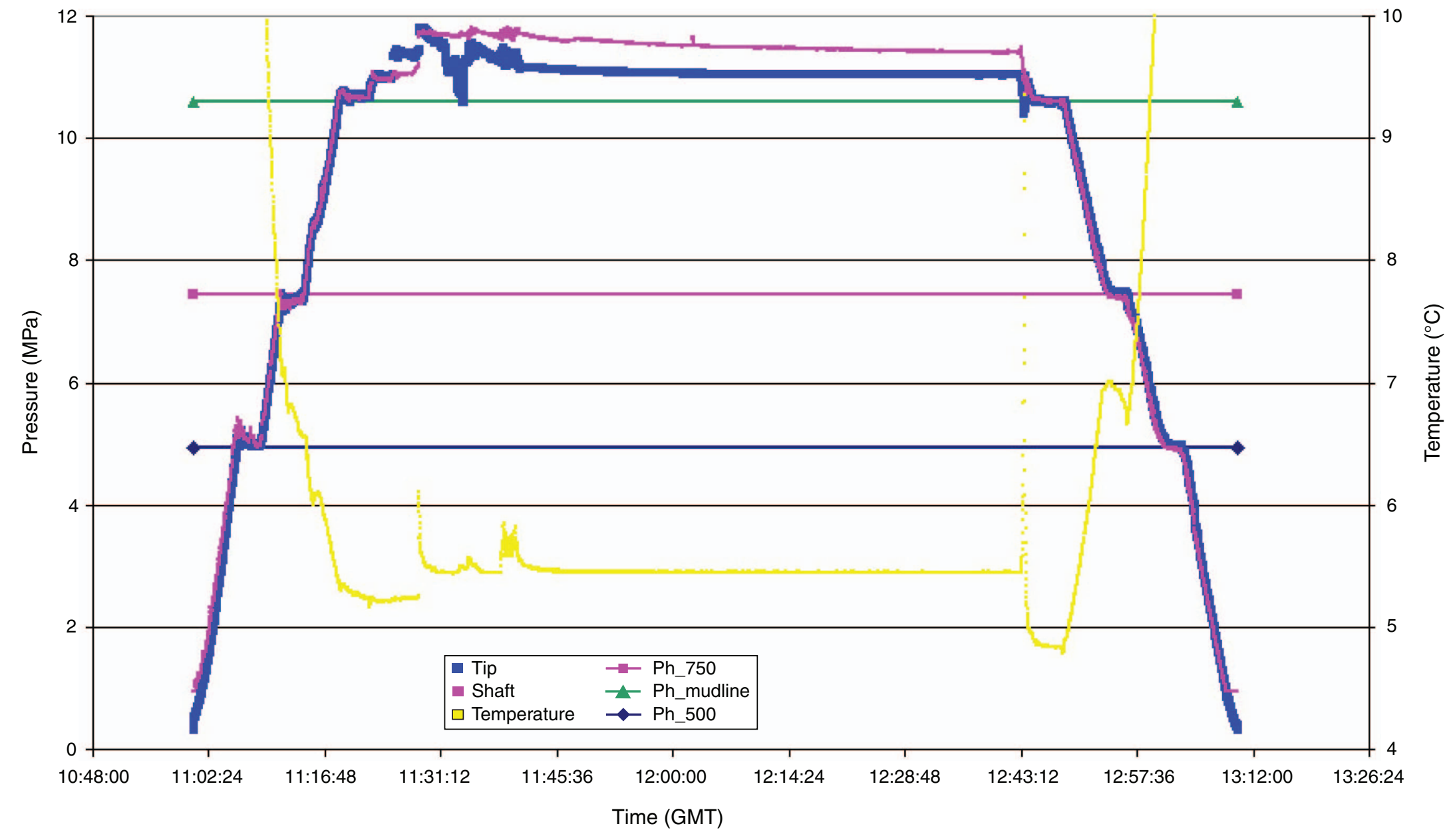


Figure F63. Fluid pressure and temperature measured by the temperature/dual pressure (T2P) probe during Deployment 13 . GMT $=$ Greenwich Mean Time. See "Downhole" in "Supplementary material."

T2P probe deployment 13 (Hole U1324C, 100 mbsf)

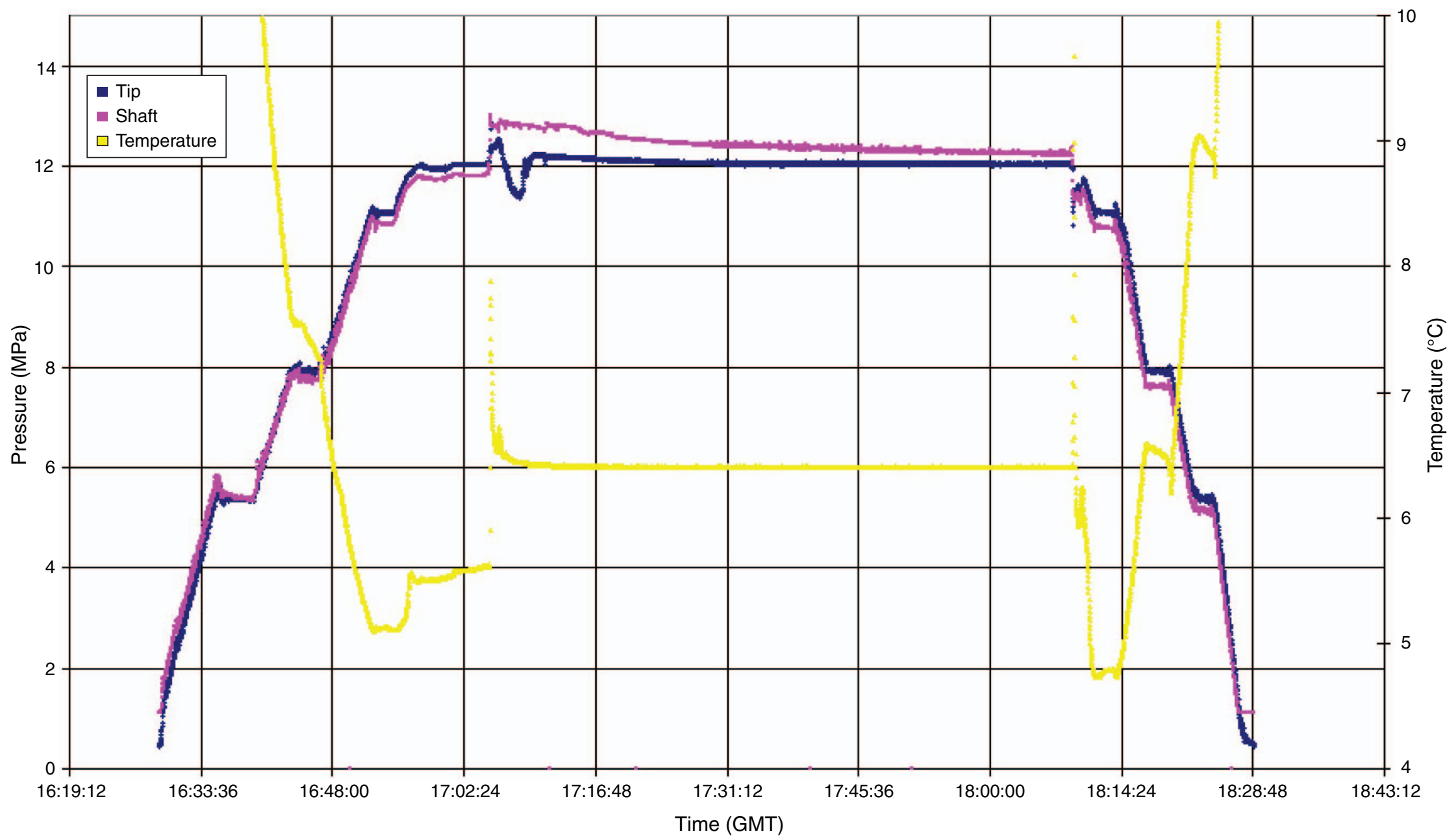


Figure F64. Fluid pressure and temperature measured by the temperature/dual pressure (T2P) probe during Deployment 14 . GMT $=$ Greenwich Mean Time. See "Downhole" in "Supplementary material."

T2P probe deployment 14 (Hole U1324C, 150 mbsf)

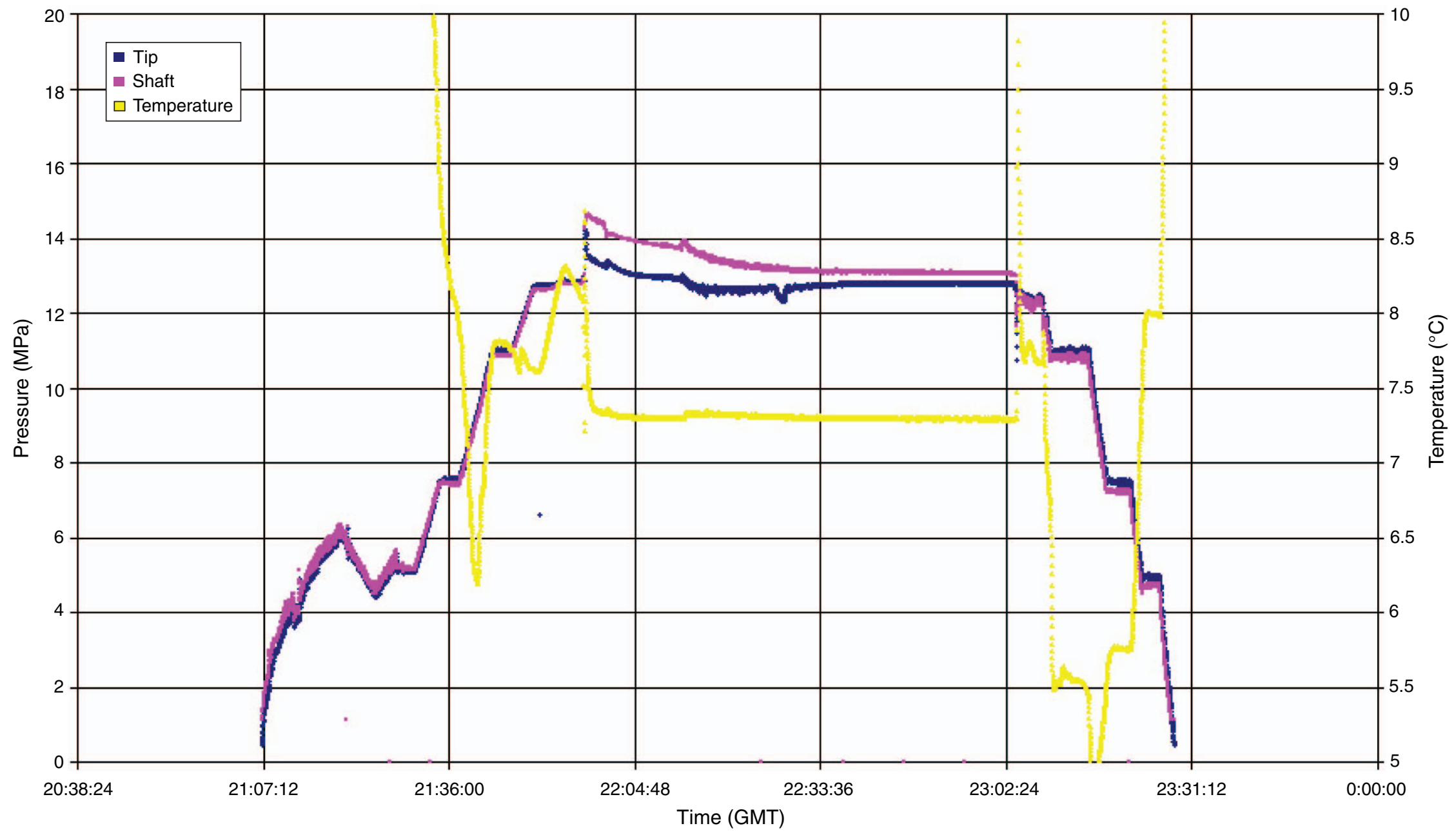


Figure F65. Fluid pressure and temperature measured by the temperature/dual pressure (T2P) probe during Deployment 15. GMT = Greenwich Mean Time. See "Downhole" in "Supplementary material."

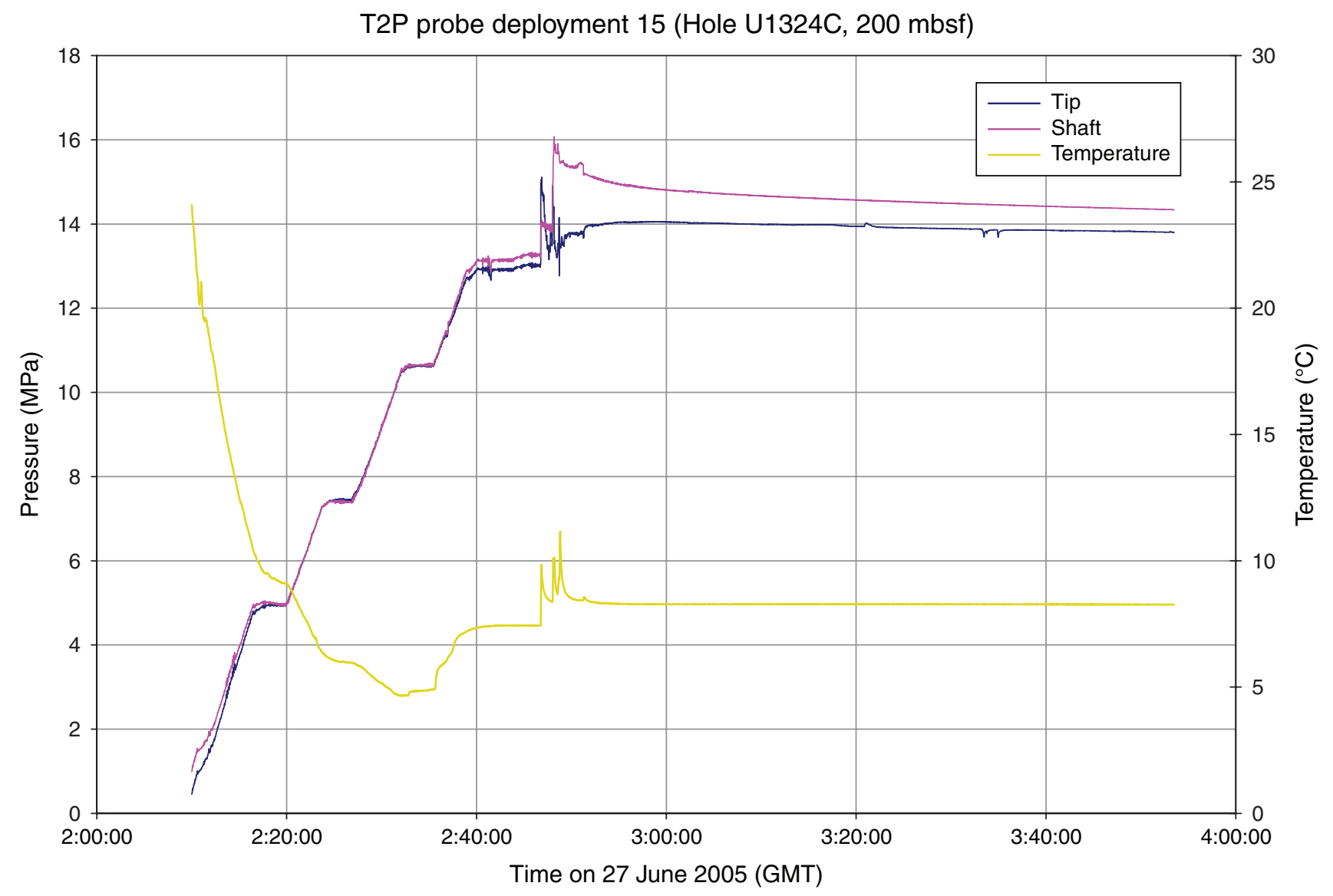


Figure F66. Fluid pressure and temperature measured by the temperature/dual pressure (T2P) probe during Deployment 16. GMT = Greenwich Mean Time. See "Downhole" in "Supplementary material."

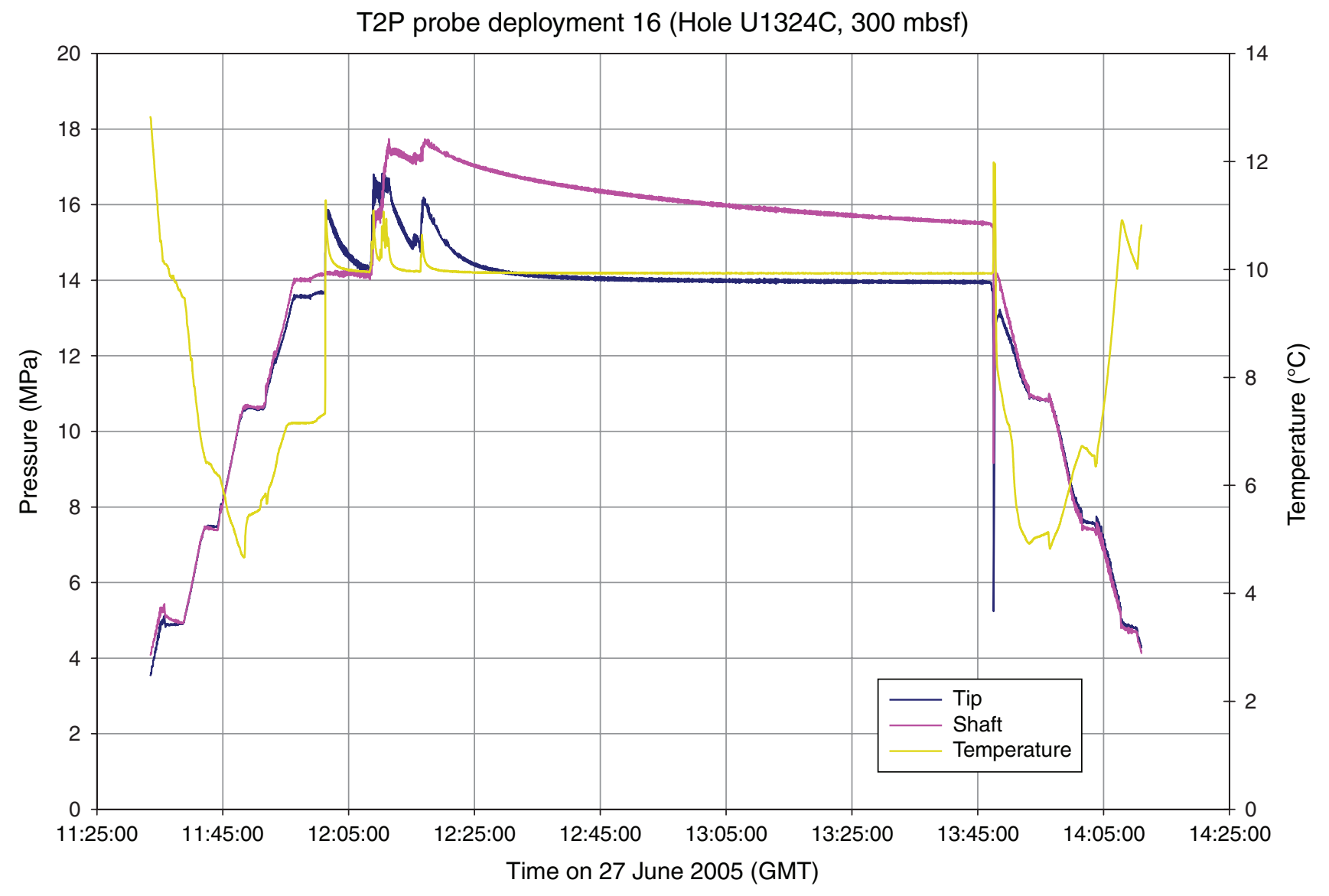


Figure F67. Fluid pressure and temperature measured by the Davis Villinger Temperature Pressure probe (DVTPP) during Deployment 3. GMT = Greenwich Mean Time. See "Downhole" in "Supplementary material."

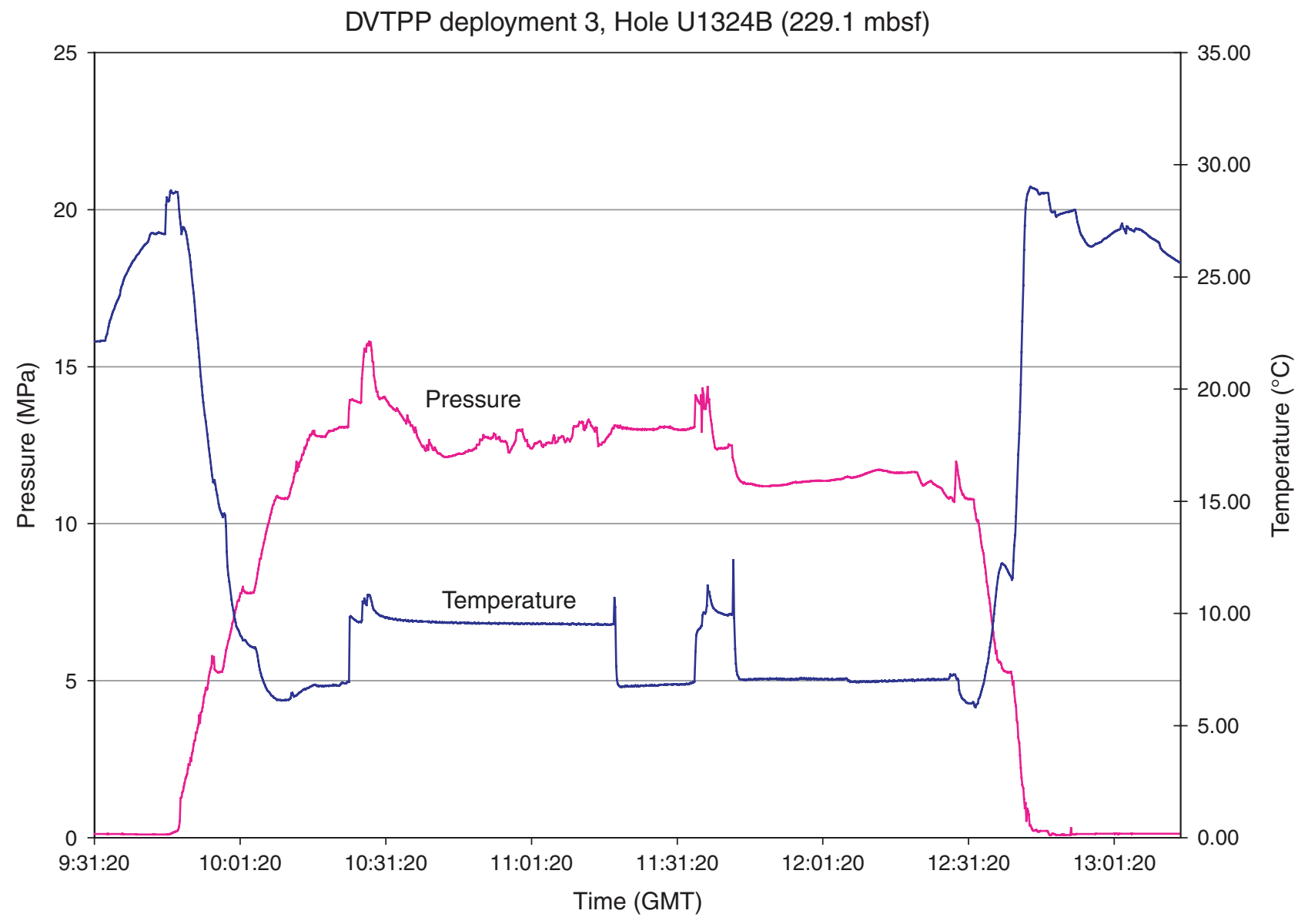


Figure F68. Fluid pressure and temperature measured by the Davis Villinger Temperature Pressure probe (DVTPP) during Deployment 4. GMT = Greenwich Mean Time. See "Downhole" in "Supplementary material."

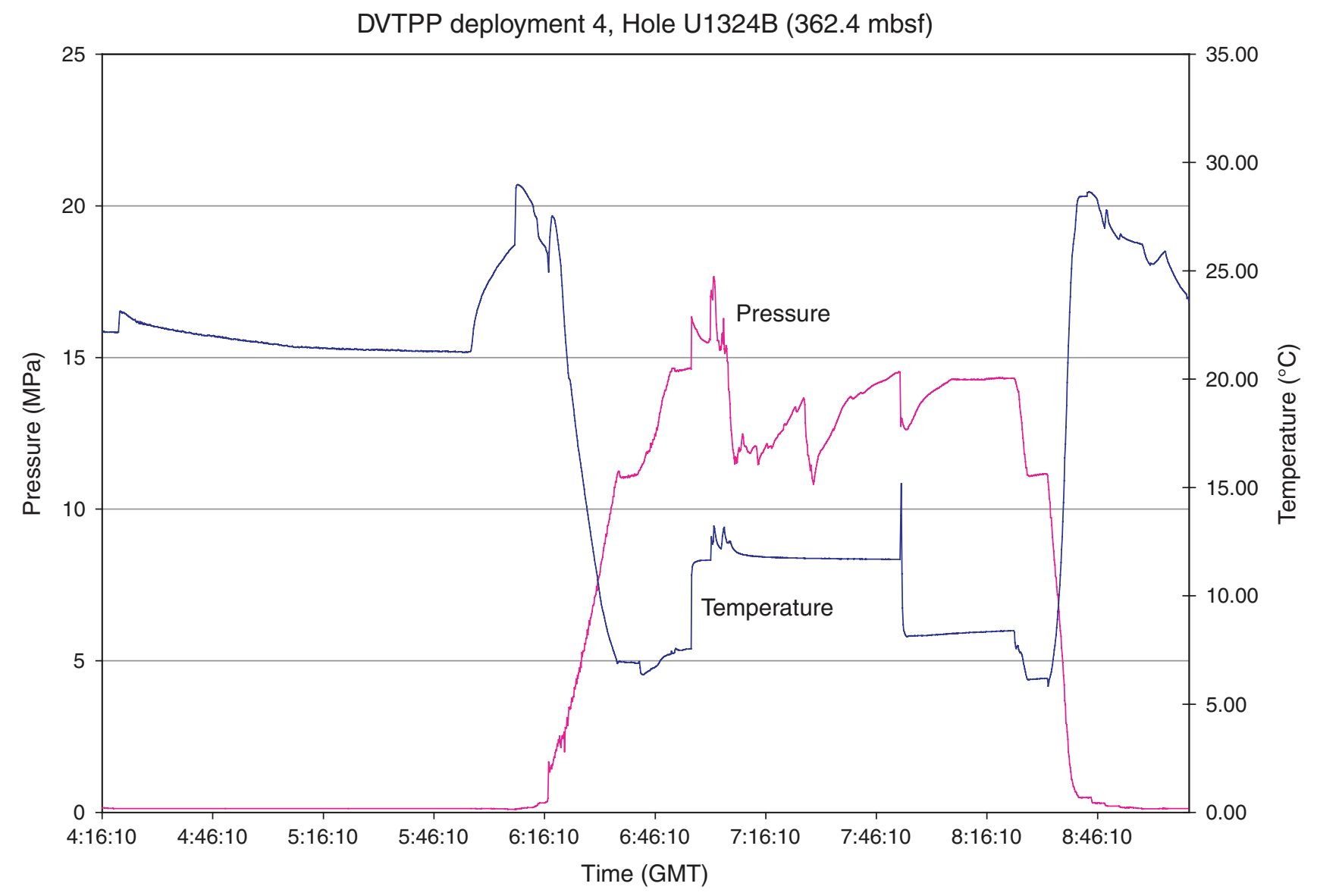


Figure F69. Fluid pressure and temperature measured by the Davis Villinger Temperature Pressure probe (DVTPP) during Deployment 6. GMT = Greenwich Mean Time. See "Downhole" in "Supplementary material."

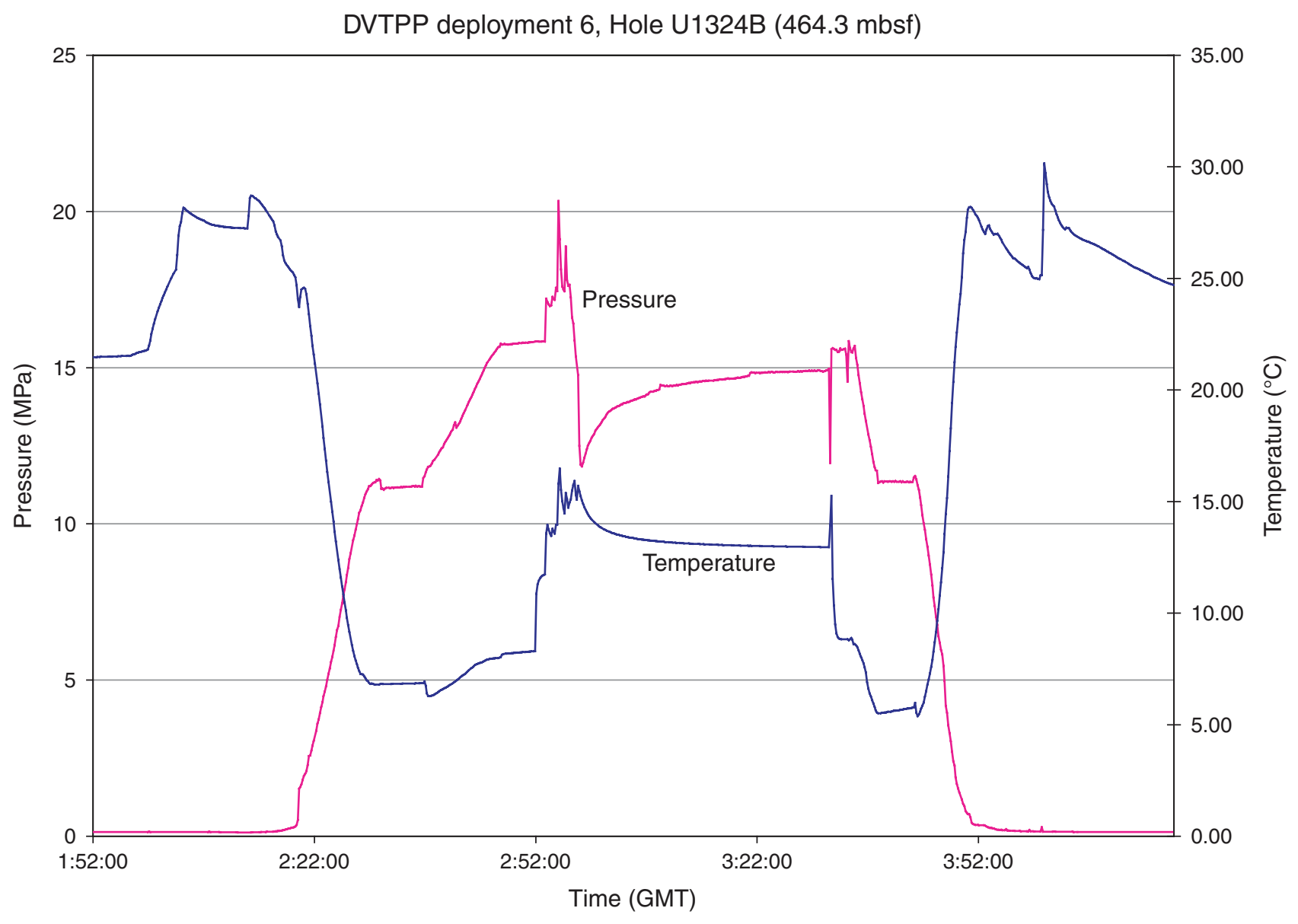


Figure F70. Fluid pressure and temperature measured by the Davis Villinger Temperature Pressure probe (DVTPP) during Deployment 7. GMT = Greenwich Mean Time. See "Downhole" in "Supplementary material."

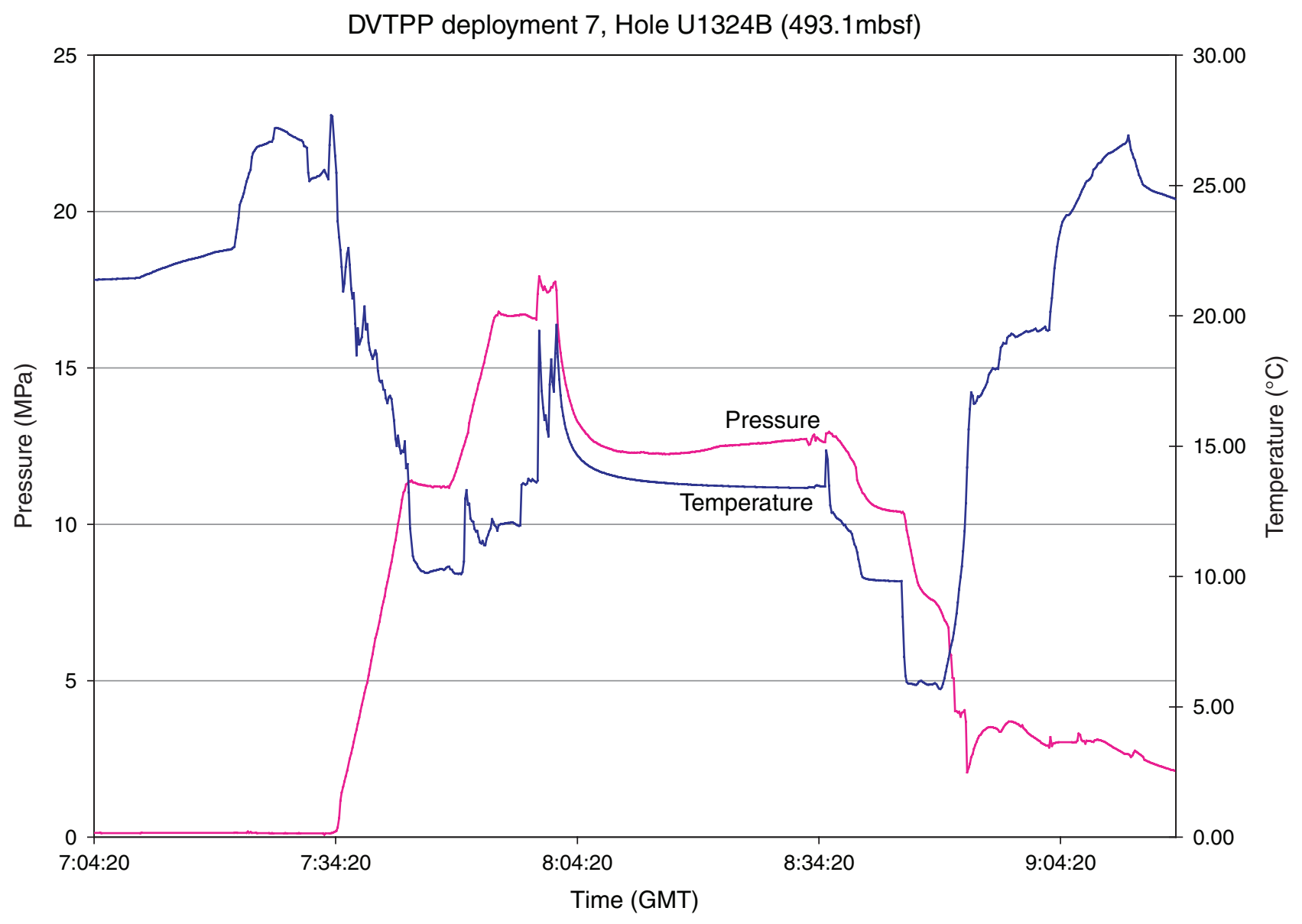


Figure F71. Fluid pressure and temperature measured by the Davis Villinger Temperature Pressure probe (DVTPP) during Deployment 8. GMT = Greenwich Mean Time. See "Downhole" in "Supplementary material."

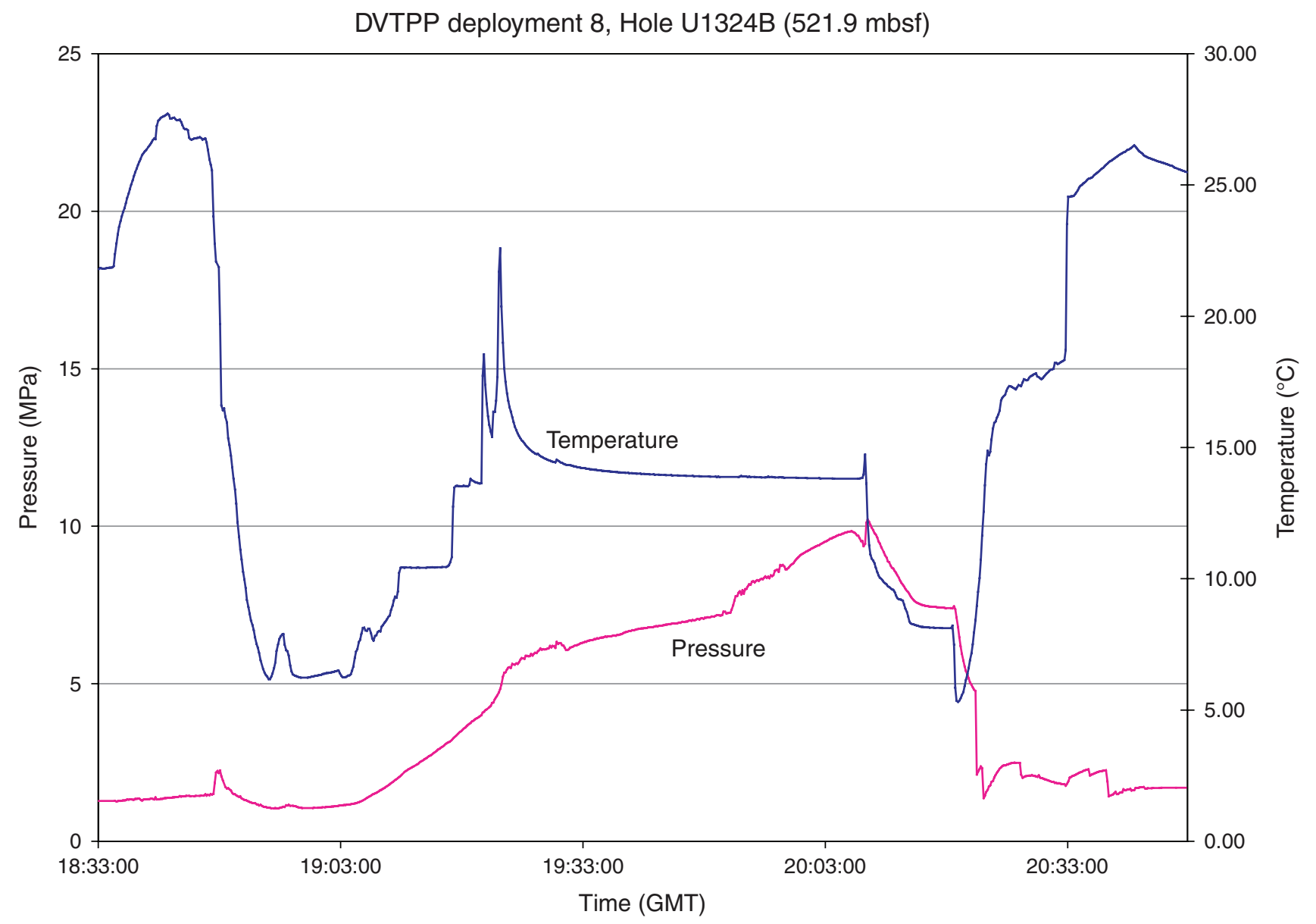


Figure F72. Fluid pressure and temperature measured by the Davis Villinger Temperature Pressure probe $($ DVTPP) during Deployment 10. GMT = Greenwich Mean Time. See "Downhole" in "Supplementary material."

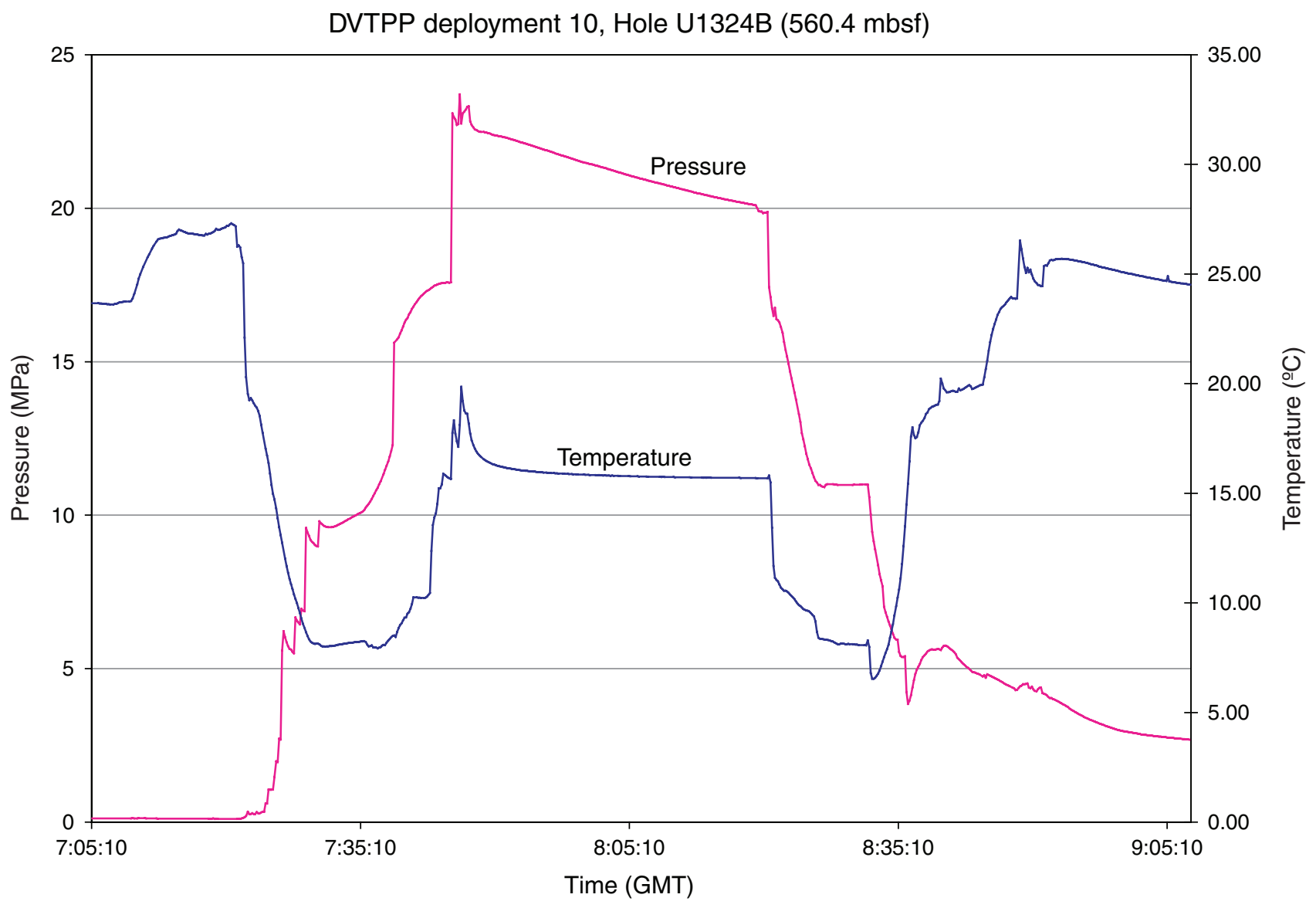


Figure F73. Fluid pressure and temperature measured by the Davis Villinger Temperature Pressure probe $($ DVTPP) during Deployment 11. GMT = Greenwich Mean Time. See "Downhole" in "Supplementary material."

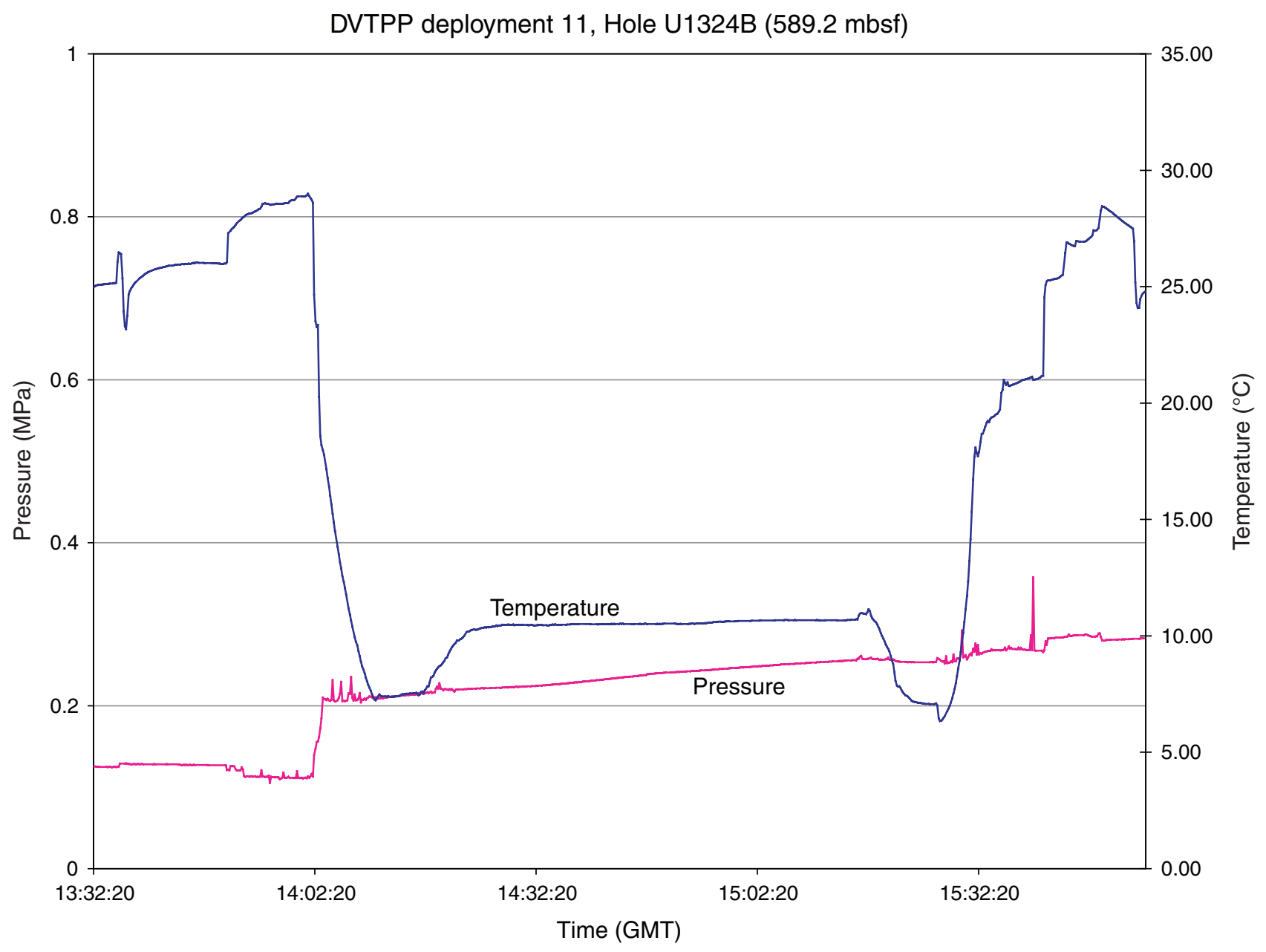


Figure F74. Fluid pressure and temperature measured by the Davis Villinger Temperature Pressure probe (DVTPP) during Deployment 12. GMT = Greenwich Mean Time. See "Downhole" in "Supplementary material."

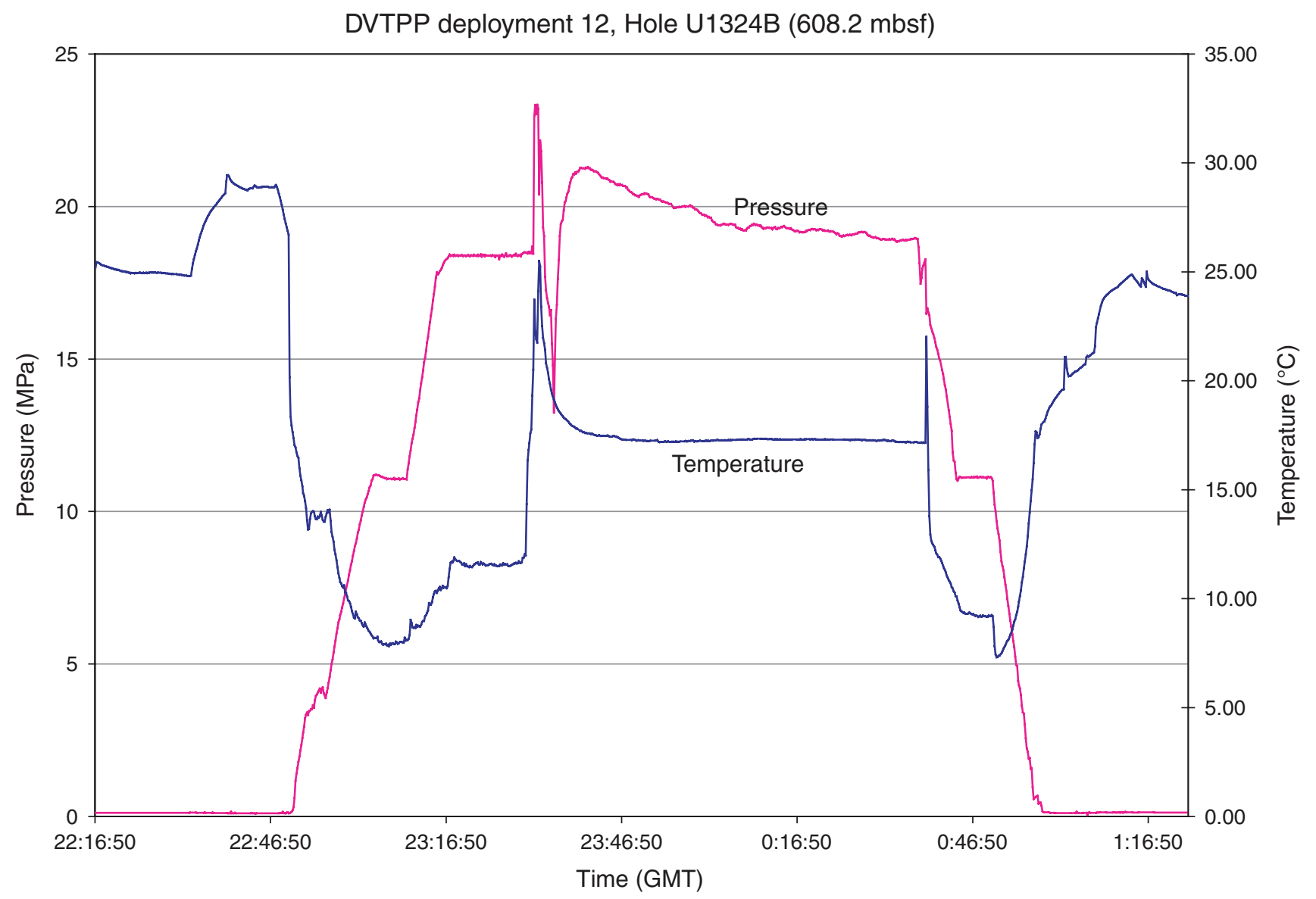


Figure F75. Fluid pressure and temperature measured by the Davis Villinger Temperature Pressure probe (DVTPP) during Deployment 13. GMT = Greenwich Mean Time. See "Downhole" in "Supplementary material."

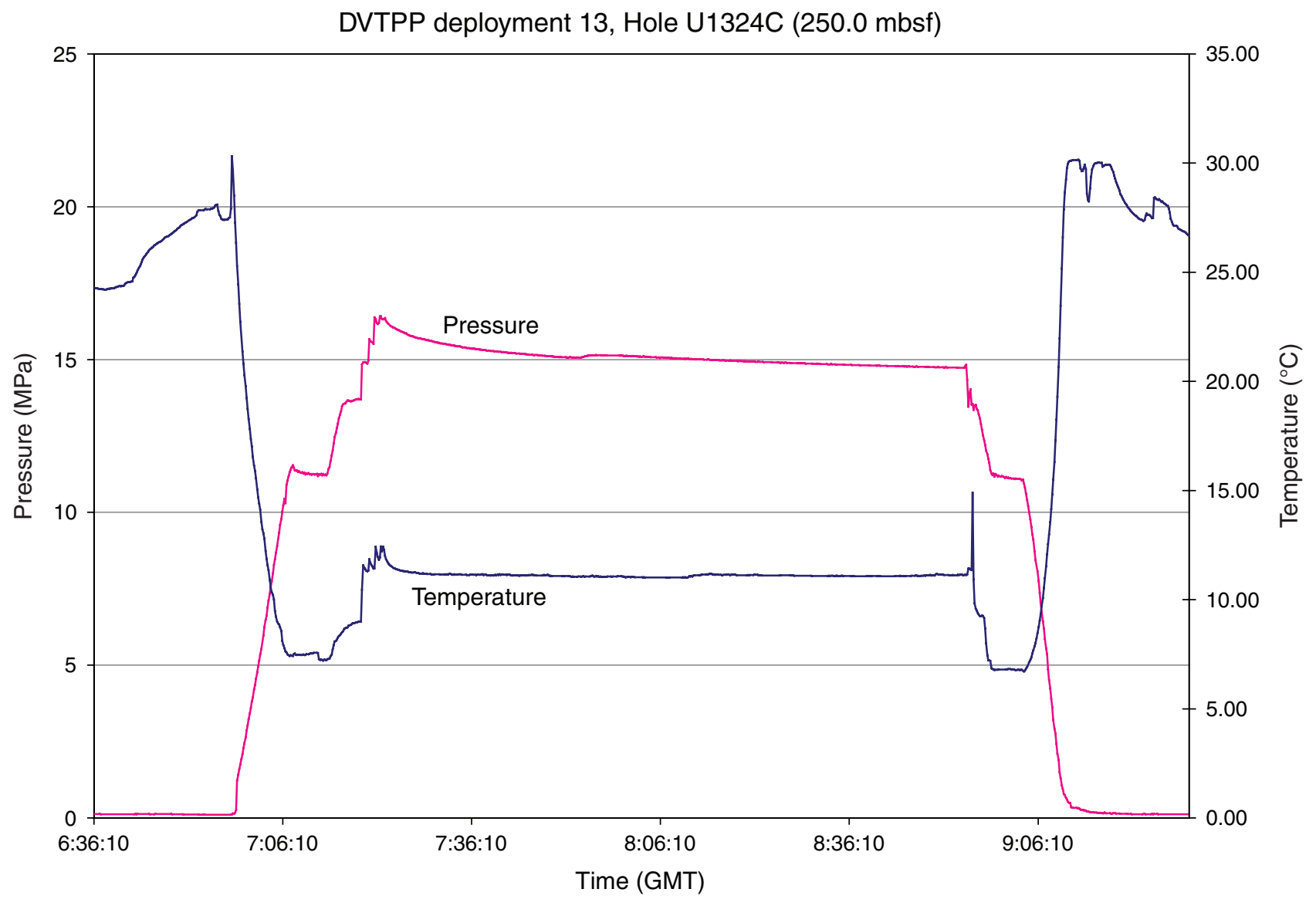


Figure F76. Fluid pressure and temperature measured by the Davis Villinger Temperature Pressure probe (DVTPP) during Deployment 14. GMT = Greenwich Mean Time. See "Downhole" in "Supplementary material."

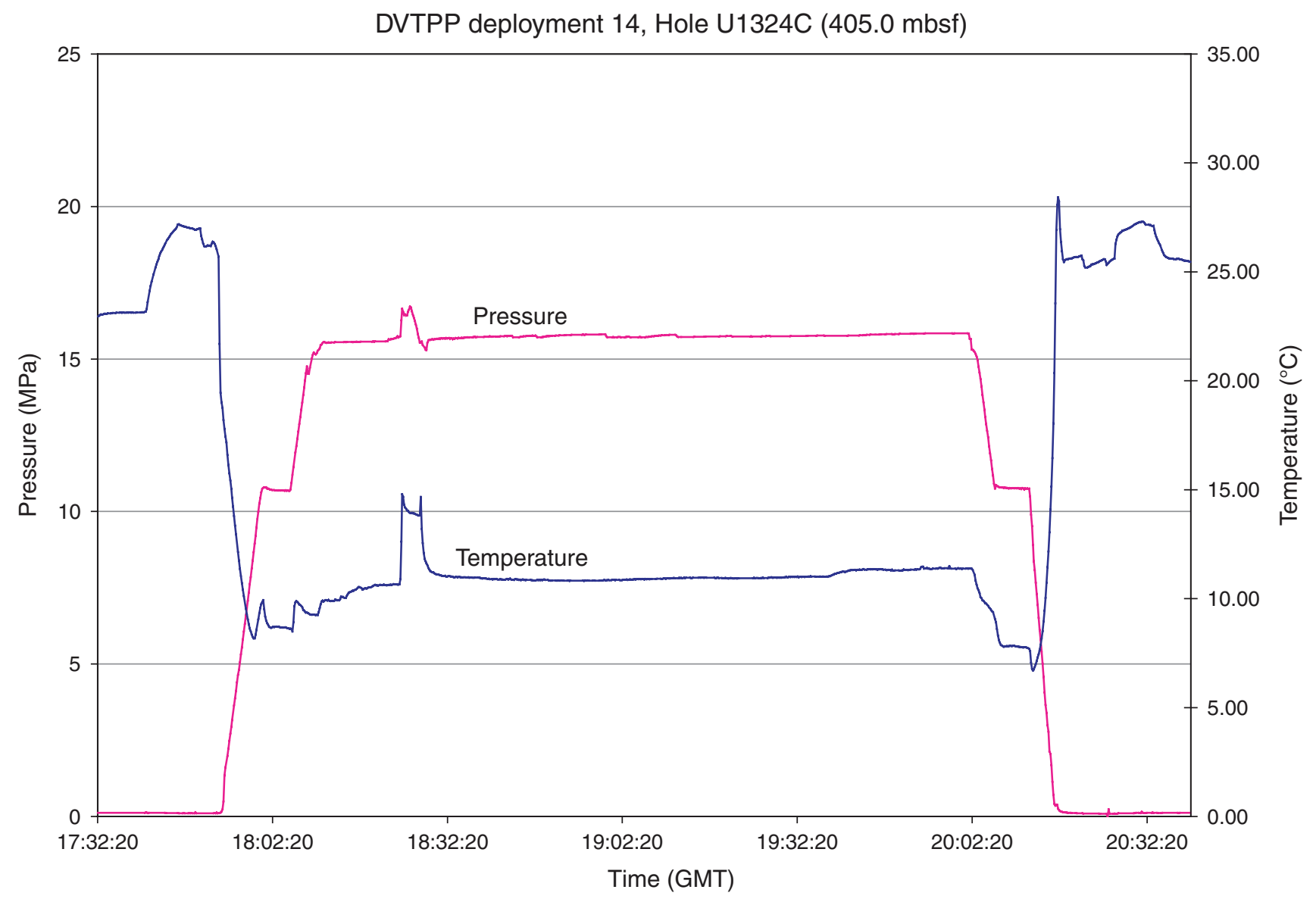


Figure F77. Fluid pressure and temperature measured by the Davis Villinger Temperature Pressure probe (DVTPP) during Deployment 15. GMT = Greenwich Mean Time. See "Downhole" in "Supplementary material."

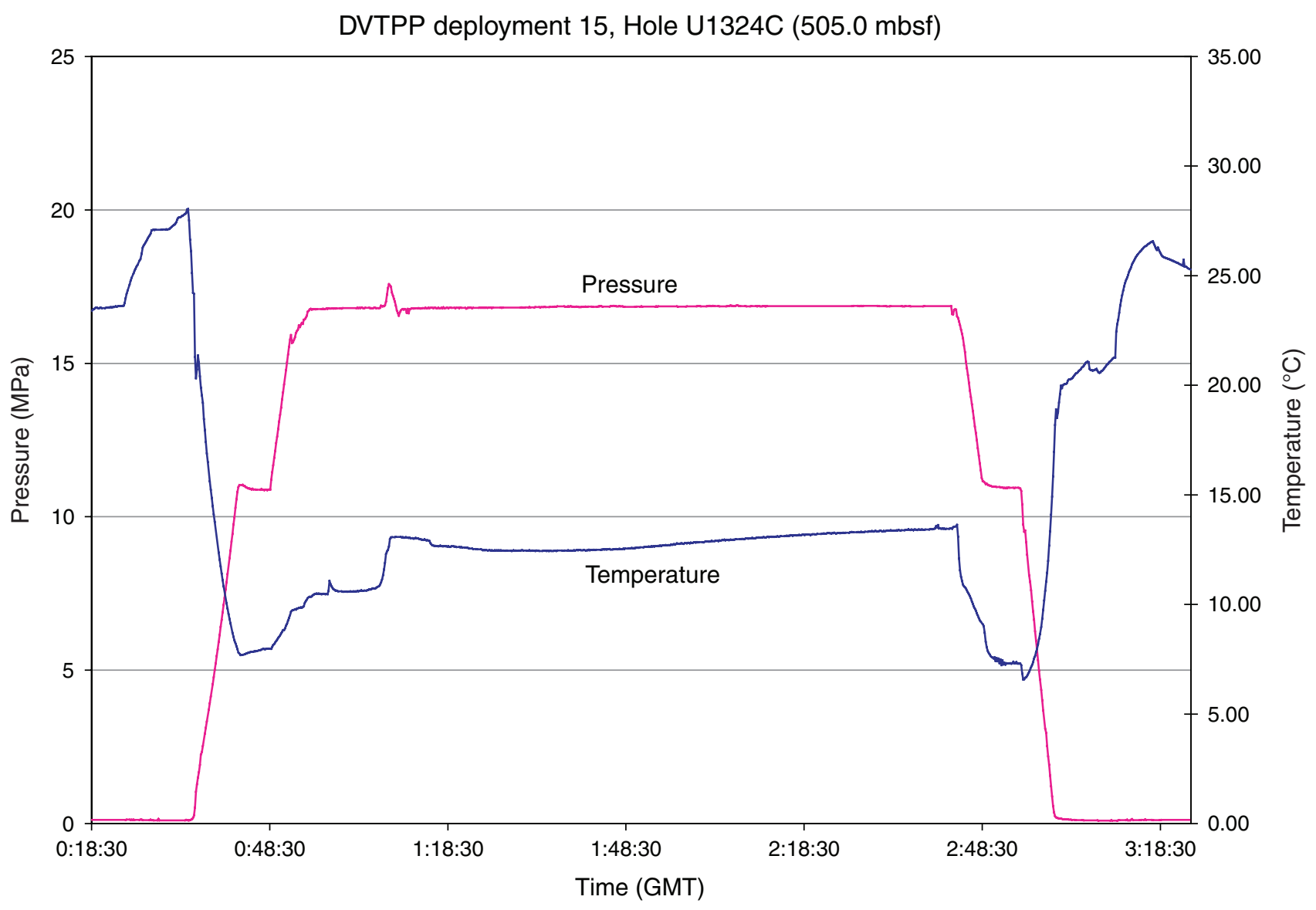


Figure F78. Equilibrium temperatures from the Advanced Piston Corer Temperature (APCT) tool, temperature/dual pressure (T2P) probe, and the Davis-Villinger Temperature-Pressure Probe $(\mathrm{DVTPP})$. Black line = linear regression of the measured temperatures which provides an average gradient of $18.4^{\circ} \mathrm{C} / \mathrm{km}$.

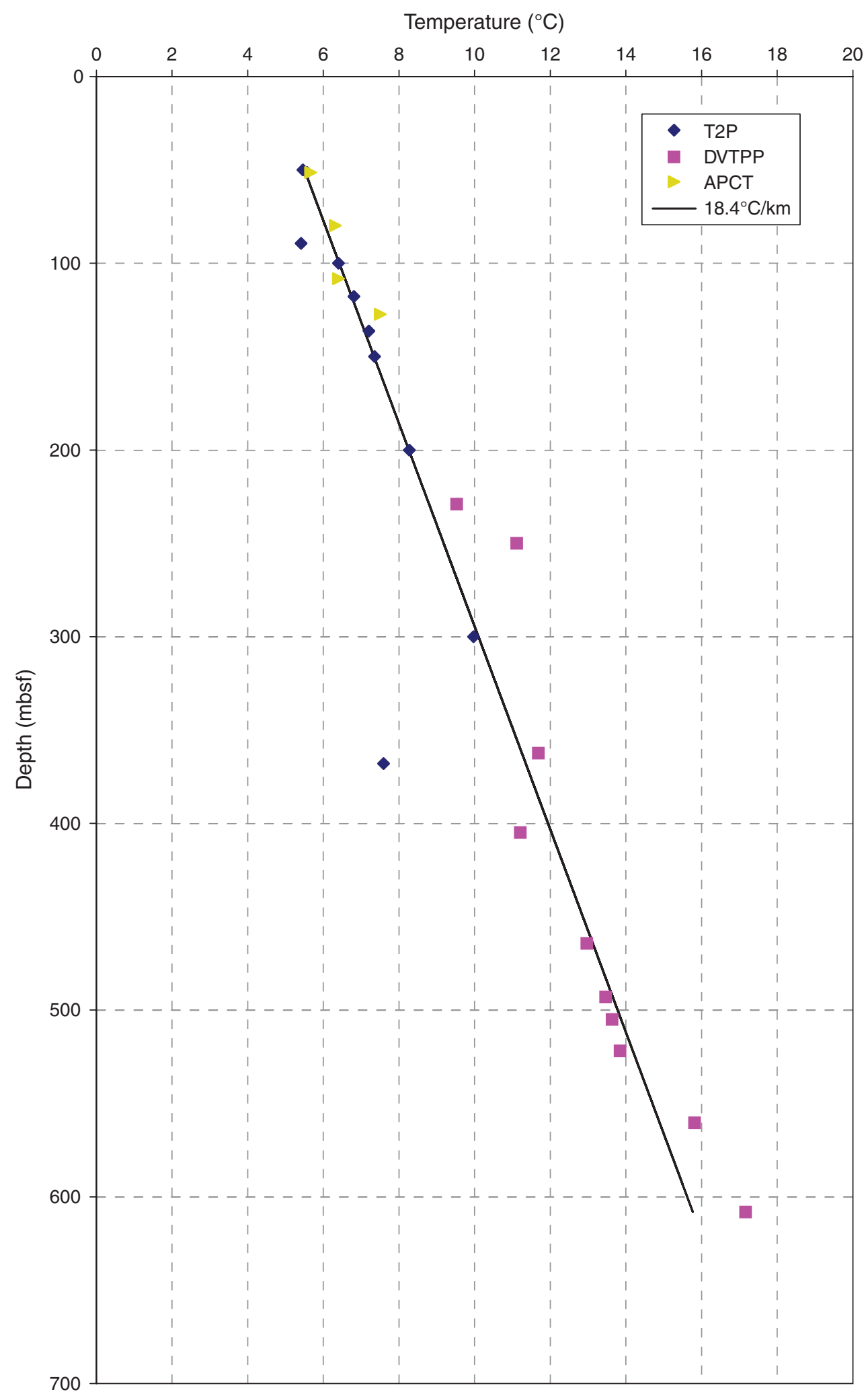


Figure F79. Maximum in situ pressures estimated from the last measurement on pressure dissipation curves from the temperature/dual pressure (T2P) probe and the Davis-Villinger Temperature-Pressure Probe (DVTPP). Hydrostatic pressure is calculated for an assumed water density of $1.024 \mathrm{~g} / \mathrm{cm}^{3}$. Lithostatic stress is calculated for an assumed bulk density of $1.700 \mathrm{~g} / \mathrm{cm}^{3}$. All pressure data are referenced to the seafloor.

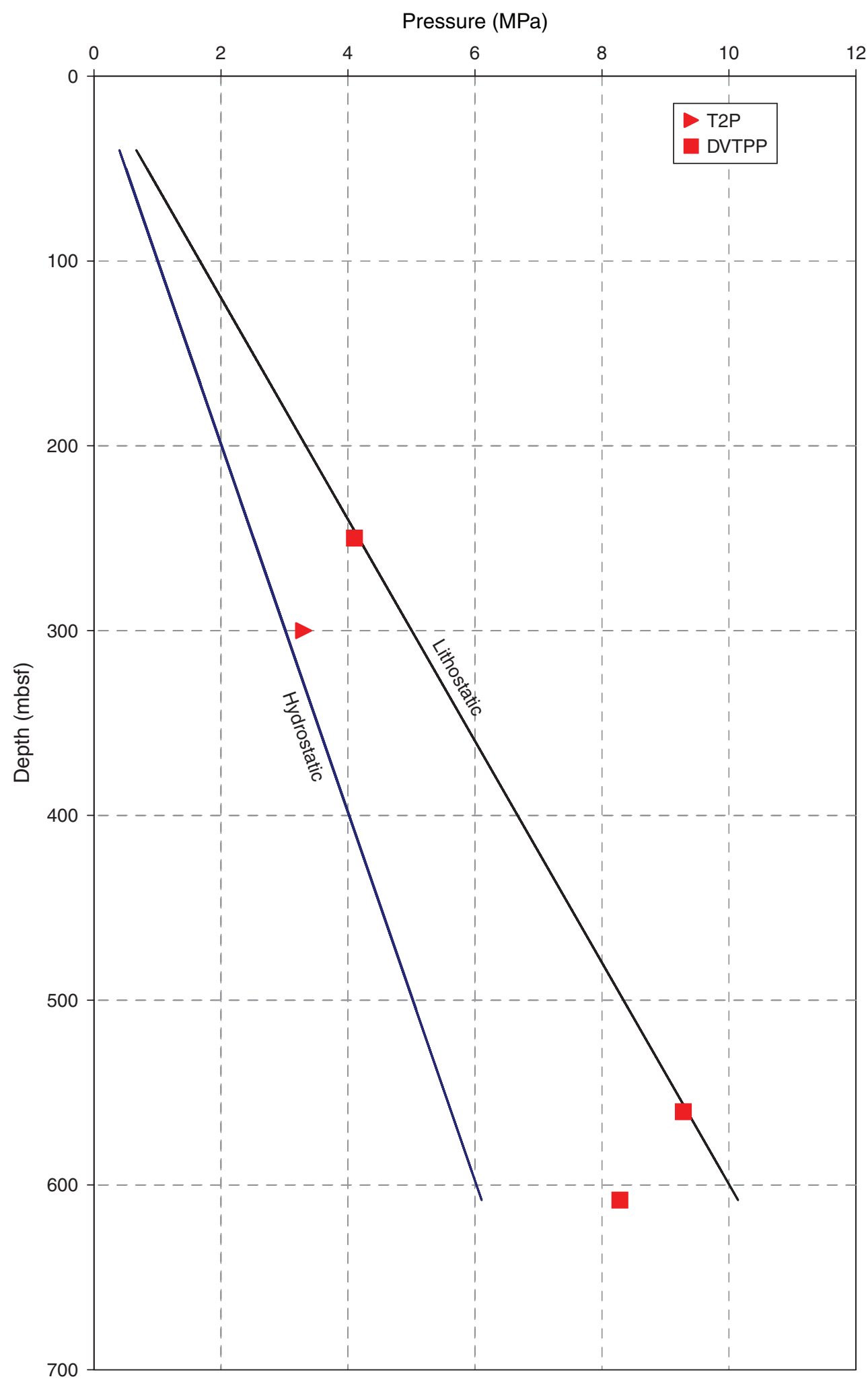


Figure F80. Pressures estimated from the last measurement on pressure dissipation curves from the temperature/dual pressure (T2P) probe and the Davis-Villinger Temperature-Pressure Probe (DVTPP). Pressures interpreted from pressure rebound curves are also shown. Hydrostatic pressure is calculated for an assumed water density of $1.024 \mathrm{~g} / \mathrm{cm}^{3}$. Lithostatic stress is calculated for an assumed bulk density of $1.7 \mathrm{~g} / \mathrm{cm}^{3}$. All pressure data are referenced to the seafloor.

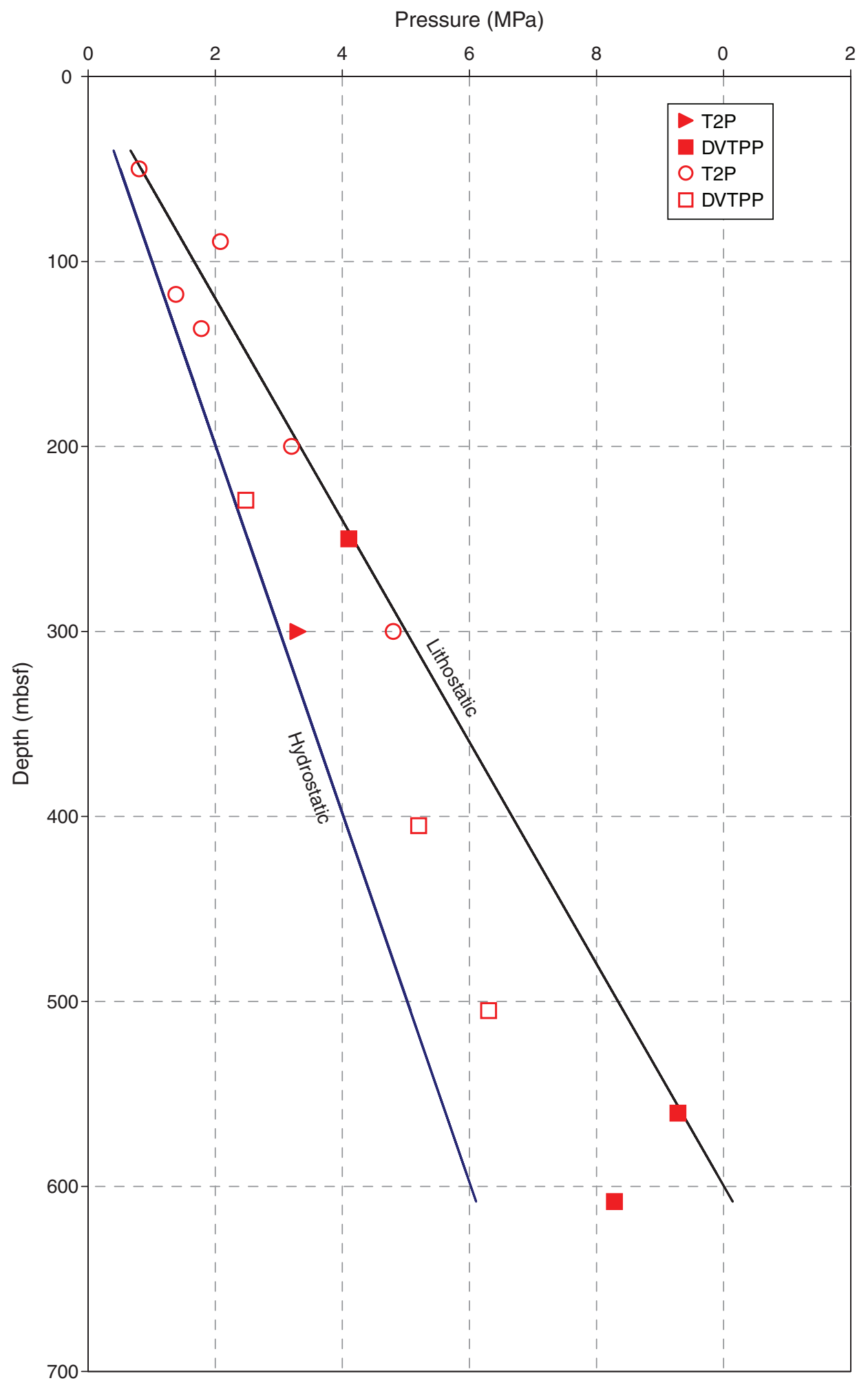


Table T1. Coring summary, Hole U1324A.

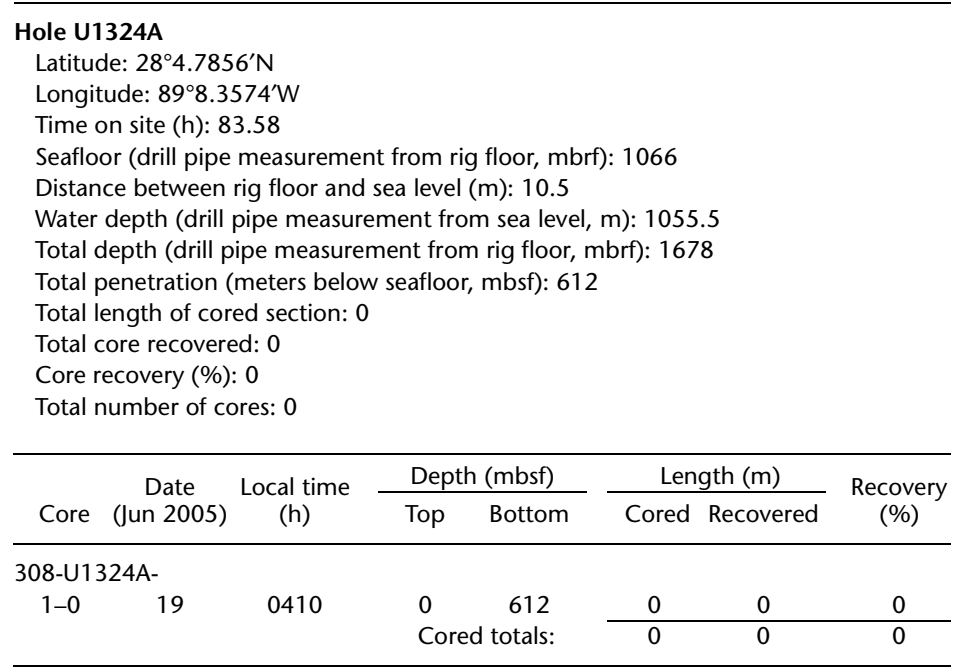

Table T2. Coring summary, Hole U1324B. (See table notes. Continued on next page.)

\begin{tabular}{|c|c|c|c|c|c|c|c|c|}
\hline \multicolumn{9}{|c|}{ Hole U1324B } \\
\hline \multicolumn{9}{|c|}{ Latitude: $28^{\circ} 4.7845^{\prime} \mathrm{N}$} \\
\hline \multicolumn{9}{|c|}{ Longitude: $89^{\circ} 8.3442^{\prime} \mathrm{W}$} \\
\hline \multicolumn{9}{|c|}{ Time on site $(\mathrm{h}): 122.17$} \\
\hline \multicolumn{9}{|c|}{ Seafloor (drill pipe measurement from rig floor, mbrf): 1067.5} \\
\hline \multicolumn{9}{|c|}{ Distance between rig floor and sea level $(\mathrm{m}): 10.7$} \\
\hline \multicolumn{9}{|c|}{ Water depth (drill pipe measurement from sea level, m): 1056.8} \\
\hline \multicolumn{9}{|c|}{ Total depth (drill pipe measurement from rig floor, mbrf): 1675.7} \\
\hline \multicolumn{9}{|c|}{ Total penetration (meters below seafloor, mbsf): 608.2} \\
\hline \multicolumn{9}{|c|}{ Total length of cored section $(\mathrm{m}): 608.2$} \\
\hline \multicolumn{9}{|c|}{ Total core recovered $(\mathrm{m}): 569.92$} \\
\hline \multicolumn{9}{|c|}{ Core recovery (\%): 94} \\
\hline \multicolumn{9}{|c|}{ Total number of cores: 74} \\
\hline \multirow[b]{2}{*}{ Core } & \multirow{2}{*}{$\begin{array}{c}\text { Date } \\
\text { un 2005) }\end{array}$} & \multirow{2}{*}{$\begin{array}{l}\text { Local time } \\
\text { (h) }\end{array}$} & \multicolumn{2}{|c|}{ Depth (mbsf) } & \multicolumn{2}{|c|}{ Length $(\mathrm{m})$} & \multirow{2}{*}{$\begin{array}{c}\text { Recovery } \\
\text { (\%) }\end{array}$} & \multirow[b]{2}{*}{ Comments } \\
\hline & & & Top & Bottom & Cored & Recovered & & \\
\hline \multicolumn{9}{|c|}{ 308-U1324B- } \\
\hline $1 \mathrm{H}$ & 21 & 0300 & 0.0 & 3.8 & 3.8 & 3.87 & 101.84 & Fluorescent microspheres \\
\hline $2 \mathrm{H}$ & 21 & 0400 & 3.8 & 13.3 & 9.5 & 9.79 & 103.05 & Fluorescent microspheres \\
\hline $3 \mathrm{H}$ & 21 & 0420 & 13.3 & 22.8 & 9.5 & 9.83 & 103.47 & Fluorescent microspheres \\
\hline $4 \mathrm{H}$ & 21 & 0500 & 22.8 & 32.3 & 9.5 & 10.03 & 105.58 & Tensor on at $0420 \mathrm{~h}$; fluorescent microspheres \\
\hline $5 \mathrm{H}$ & 21 & 0530 & 32.3 & 41.8 & 9.5 & 10.04 & 105.68 & Fluorescent microspheres \\
\hline $6 \mathrm{H}$ & 21 & 0625 & 41.8 & 51.3 & 9.5 & 10.06 & 105.89 & $\mathrm{~T} 2 \mathrm{P}$ probe; fluorescent microspheres \\
\hline 7H & 21 & 0900 & 51.3 & 60.8 & 9.5 & 9.98 & 105.05 & Fluorescent microspheres \\
\hline $8 \mathrm{H}$ & 21 & 0935 & 60.8 & 70.3 & 9.5 & 9.84 & 103.58 & Fluorescent microspheres \\
\hline $9 \mathrm{H}$ & 21 & 1025 & 70.3 & 79.8 & 9.5 & 10.05 & 105.79 & Fluorescent microspheres \\
\hline $10 \mathrm{H}$ & 21 & 1105 & 79.8 & 89.3 & 9.5 & 9.79 & 103.05 & Tensor on at $1100 \mathrm{~h}$; T2P probe, $30 \mathrm{~K}$ overpull; fluorescent microspheres \\
\hline $11 \mathrm{H}$ & 21 & 1415 & 89.3 & 98.8 & 9.5 & 9.48 & 99.79 & Fluorescent microspheres \\
\hline $12 \mathrm{H}$ & 21 & 1510 & 98.8 & 108.3 & 9.5 & 9.76 & 102.74 & \\
\hline $13 \mathrm{H}$ & 21 & 1545 & 108.3 & 117.8 & 9.5 & 9.91 & 104.32 & T2P probe; fluorescent microspheres \\
\hline $14 \mathrm{H}$ & 21 & 1900 & 117.8 & 127.3 & 9.5 & 8.07 & 84.95 & Tensor on at $1845 \mathrm{~h}$; pump out liner \\
\hline $15 \mathrm{H}$ & 21 & 2025 & 127.3 & 136.3 & 9.0 & 9.06 & 100.67 & $\mathrm{~T} 2 \mathrm{P}$ probe; fluorescent microspheres \\
\hline $16 \mathrm{H}$ & 21 & 2325 & 136.3 & 144.9 & 8.6 & 8.63 & 100.35 & Advance by recovery; pump out liner \\
\hline $17 \mathrm{H}$ & 22 & 0100 & 144.9 & 153.7 & 8.8 & 8.84 & 100.45 & Advance by recovery; fluorescent microspheres \\
\hline $18 \mathrm{H}$ & 22 & 0150 & 153.7 & 162.0 & 8.3 & 8.35 & 100.60 & Advance by recovery \\
\hline $19 \mathrm{H}$ & 22 & 0240 & 162.0 & 170.8 & 8.8 & 8.81 & 100.11 & Advance by recovery; Tensor out at $0240 \mathrm{~h}$; fluorescent microspheres \\
\hline $20 \mathrm{H}$ & 22 & 0330 & 170.8 & 179.0 & 8.2 & 8.19 & 99.88 & Advance by recovery; Tensor on at $0230 \mathrm{~h}$ \\
\hline $21 \mathrm{H}$ & 22 & 0430 & 179.0 & 186.9 & 7.9 & 7.92 & 100.25 & Advance by recovery; fluorescent microspheres \\
\hline $22 \mathrm{H}$ & 22 & 0510 & 186.9 & 193.8 & 6.9 & 6.99 & 101.30 & Advance by recovery \\
\hline $23 \mathrm{H}$ & 22 & 0600 & 193.8 & 200.4 & 6.6 & 6.70 & 101.52 & Advance by recovery; fluorescent microspheres \\
\hline $24 \mathrm{H}$ & 22 & 0655 & 200.4 & 207.5 & 7.1 & 7.15 & 100.70 & Advance by recovery \\
\hline $25 \mathrm{H}$ & 22 & 0740 & 207.5 & 216.1 & 8.6 & 8.60 & 100.00 & Advance by recovery \\
\hline $26 \mathrm{H}$ & 22 & 0830 & 216.1 & 222.5 & 6.4 & 6.48 & 101.25 & Advance by recovery; fluorescent microspheres \\
\hline
\end{tabular}


Table T2 (continued).

\begin{tabular}{|c|c|c|c|c|c|c|c|c|}
\hline \multirow{2}{*}{ Core } & \multirow{2}{*}{$\begin{array}{c}\text { Date } \\
\text { (Jun 2005) }\end{array}$} & \multirow{2}{*}{$\begin{array}{l}\text { Local time } \\
\text { (h) }\end{array}$} & \multicolumn{2}{|c|}{ Depth (mbsf) } & \multicolumn{2}{|c|}{ Length (m) } & \multirow{2}{*}{$\begin{array}{l}\text { Recovery } \\
\text { (\%) }\end{array}$} & \multirow[b]{2}{*}{ Comments } \\
\hline & & & Top & Bottom & Cored & Recovered & & \\
\hline $27 \mathrm{H}$ & 22 & 0925 & 222.5 & 229.1 & 6.6 & 6.61 & 100.15 & Tensor out at $0925 \mathrm{~h}$; DVTPP at $1296.6 \mathrm{~m}$ \\
\hline $28 \mathrm{H}$ & 22 & 1335 & 229.1 & 238.6 & 9.5 & 9.63 & 101.37 & \\
\hline $29 \mathrm{H}$ & 22 & 1435 & 238.6 & 247.3 & 8.7 & 8.73 & 100.34 & Fluorescent microspheres \\
\hline $30 \mathrm{H}$ & 22 & 1510 & 247.3 & 256.8 & 9.5 & 9.72 & 102.32 & \\
\hline $31 \mathrm{H}$ & 22 & 1555 & 256.8 & 264.6 & 7.8 & 7.80 & 100.00 & \\
\hline $32 \mathrm{H}$ & 22 & 1640 & 264.6 & 273.7 & 9.1 & 9.10 & 100.00 & Changed all seals on APC after Core $32 \mathrm{H}$; fluorescent microspheres \\
\hline $33 \mathrm{H}$ & 22 & 1745 & 273.7 & 282.5 & 8.8 & 8.78 & 99.77 & \\
\hline $34 \mathrm{H}$ & 22 & 1825 & 282.5 & 290.4 & 7.9 & 7.92 & 100.25 & \\
\hline $35 \mathrm{H}$ & 22 & 1935 & 290.4 & 296.4 & 6.0 & 6.06 & 101.00 & Fluorescent microspheres \\
\hline $36 \mathrm{H}$ & 22 & 2015 & 296.4 & 305.6 & 9.2 & 9.30 & 101.09 & \\
\hline $37 \mathrm{H}$ & 22 & 2105 & 305.6 & 311.3 & 5.7 & 5.75 & 100.88 & Changed inner and outer seals after Core $37 \mathrm{H}$ \\
\hline $38 \mathrm{H}$ & 22 & 2205 & 311.3 & 319.2 & 7.9 & 7.98 & 101.01 & Fluorescent microspheres \\
\hline $39 \mathrm{H}$ & 22 & 2340 & 319.2 & 327.6 & 8.4 & 8.45 & 100.60 & \\
\hline $40 \mathrm{H}$ & 23 & 0025 & 327.6 & 333.5 & 5.9 & 5.97 & 101.19 & Tensor on at $0025 \mathrm{~h}$ \\
\hline $41 \mathrm{H}$ & 23 & 0135 & 333.5 & 339.0 & 5.5 & 5.52 & 100.36 & Fluorescent microspheres \\
\hline $42 \mathrm{H}$ & 23 & 0225 & 339.0 & 345.0 & 6.0 & 5.96 & 99.33 & \\
\hline $43 \mathrm{H}$ & 23 & 0325 & 345.0 & 352.7 & 7.7 & 7.79 & 101.17 & \\
\hline $44 \mathrm{H}$ & 23 & 0430 & 352.7 & 357.9 & 5.2 & 5.14 & 98.85 & Fluorescent microspheres; Tensor out at $0500 \mathrm{~h}$ \\
\hline $45 X$ & 23 & 0550 & 357.9 & 362.4 & 4.5 & 4.57 & 101.56 & DVTPP; sheared pin on overshot \\
\hline $46 X$ & 23 & 0945 & 362.4 & 368.0 & 5.6 & 5.33 & 95.18 & $\mathrm{~T} 2 \mathrm{P}$ probe at $1435.9 \mathrm{~m}$ \\
\hline $47 \mathrm{H}$ & 23 & 1300 & 368.0 & 373.2 & 5.2 & 5.26 & 101.15 & Tensor at $1200 \mathrm{~h}$; fluorescent microspheres \\
\hline $48 \mathrm{H}$ & 23 & 1400 & 373.2 & 381.5 & 8.3 & 8.38 & 100.96 & \\
\hline $49 \mathrm{H}$ & 23 & 1445 & 381.5 & 387.9 & 6.4 & 6.36 & 99.38 & DVTPP at $1455.4 \mathrm{~m}$ \\
\hline $50 \mathrm{H}$ & 23 & 1715 & 387.9 & 394.5 & 6.6 & 6.64 & 100.61 & T2P probe at $1462.0 \mathrm{~m}$ \\
\hline $51 x$ & 23 & 2055 & 394.5 & 396.8 & 2.3 & 2.31 & 100.43 & \\
\hline $52 X$ & 23 & 2145 & 396.8 & 406.4 & 9.6 & 7.29 & 75.94 & \\
\hline $53 x$ & 23 & 2225 & 406.4 & 416.0 & 9.6 & 7.39 & 76.98 & \\
\hline $54 X$ & 23 & 2305 & 416.0 & 425.7 & 9.7 & 5.32 & 54.85 & \\
\hline $55 X$ & 23 & 2350 & 425.7 & 435.3 & 9.6 & 9.68 & 100.83 & \\
\hline $56 x$ & 24 & 0030 & 435.3 & 445.0 & 9.7 & 8.34 & 85.98 & \\
\hline $57 X$ & 24 & 0110 & 445.0 & 454.6 & 9.6 & 8.75 & 91.15 & \\
\hline $58 \mathrm{X}$ & 24 & 0145 & 454.6 & 464.3 & 9.7 & 9.70 & 100.00 & DVTPP at $1531.8 \mathrm{~m}$ (464.3 mbsf) \\
\hline $59 x$ & 24 & 0445 & 464.3 & 473.9 & 9.6 & 9.65 & 100.52 & \\
\hline $60 x$ & 24 & 0535 & 473.9 & 483.5 & 9.6 & 9.84 & 102.50 & \\
\hline $61 X$ & 24 & 0710 & 483.5 & 493.1 & 9.6 & 9.65 & 100.52 & Core with 10.5 ppg mud; DVTPP \\
\hline $62 X$ & 24 & 1030 & 493.1 & 502.7 & 9.6 & 8.76 & 91.25 & 10.5 ppg mud, S/B out \\
\hline $63 x$ & 24 & 1155 & 502.7 & 512.4 & 9.7 & 7.28 & 75.05 & $10.5 \mathrm{ppg}$ mud \\
\hline $64 X$ & 24 & 1310 & 512.4 & 521.9 & 9.5 & 4.98 & 52.42 & $10.5 \mathrm{ppg}$ mud; DVTPP at $1589.4 \mathrm{~m}$ \\
\hline $65 x$ & 24 & 1810 & 521.9 & 531.6 & 9.7 & 8.41 & 86.70 & $10.5 \mathrm{ppg}$ mud \\
\hline $66 x$ & 24 & 2030 & 531.6 & 541.1 & 9.5 & 1.62 & 17.05 & $10.5 \mathrm{ppg}$ mud; DVTPP at $1608.6 \mathrm{~m}$ \\
\hline $67 X$ & 25 & 0015 & 541.1 & 550.7 & 9.6 & 8.42 & 87.71 & $10.5 \mathrm{ppg}$ mud \\
\hline $68 \mathrm{X}$ & 25 & 0200 & 550.7 & 560.4 & 9.7 & 7.86 & 81.03 & $10.5 \mathrm{ppg}$ mud; DVTPP at $1627.9 \mathrm{~m}$ \\
\hline $69 X$ & 25 & 0525 & 560.4 & 570.0 & 9.6 & 4.02 & 41.87 & $10.5 \mathrm{ppg}$ mud \\
\hline $70 x$ & 25 & 0650 & 570.0 & 579.6 & 9.6 & 8.55 & 89.06 & $10.5 \mathrm{ppg}$ mud \\
\hline $71 \mathrm{X}$ & 25 & 0840 & 579.6 & 589.2 & 9.6 & 8.39 & 87.40 & $10.5 \mathrm{ppg}$ mud; DVTPP at $1656.7 \mathrm{~m}$ \\
\hline $72 X$ & 25 & 1215 & 589.2 & 593.2 & 4.0 & 3.94 & 98.50 & $10.5 \mathrm{ppg}$ mud; T2P probe at $1660.7 \mathrm{~m}$ \\
\hline $73 x$ & 25 & 1530 & 593.2 & 598.6 & 5.4 & 2.68 & 49.63 & $10.5 \mathrm{ppg}$ mud \\
\hline \multirow{2}{*}{$74 X$} & 25 & 1720 & 598.6 & 608.2 & 9.6 & 8.12 & 84.58 & $10.5 \mathrm{ppg}$ mud; DVTPP at $1675.7 \mathrm{~m}$ \\
\hline & & & \multicolumn{2}{|c|}{ Cored totals: } & 608.2 & 569.92 & 93.71 & \\
\hline
\end{tabular}

Notes: T2P = temperature/dual pressure probe, DVTPP = Davis-Villinger Temperature-Pressure Probe. APC = advanced piston corer. 
Table T3. Coring summary, Hole U1324C.

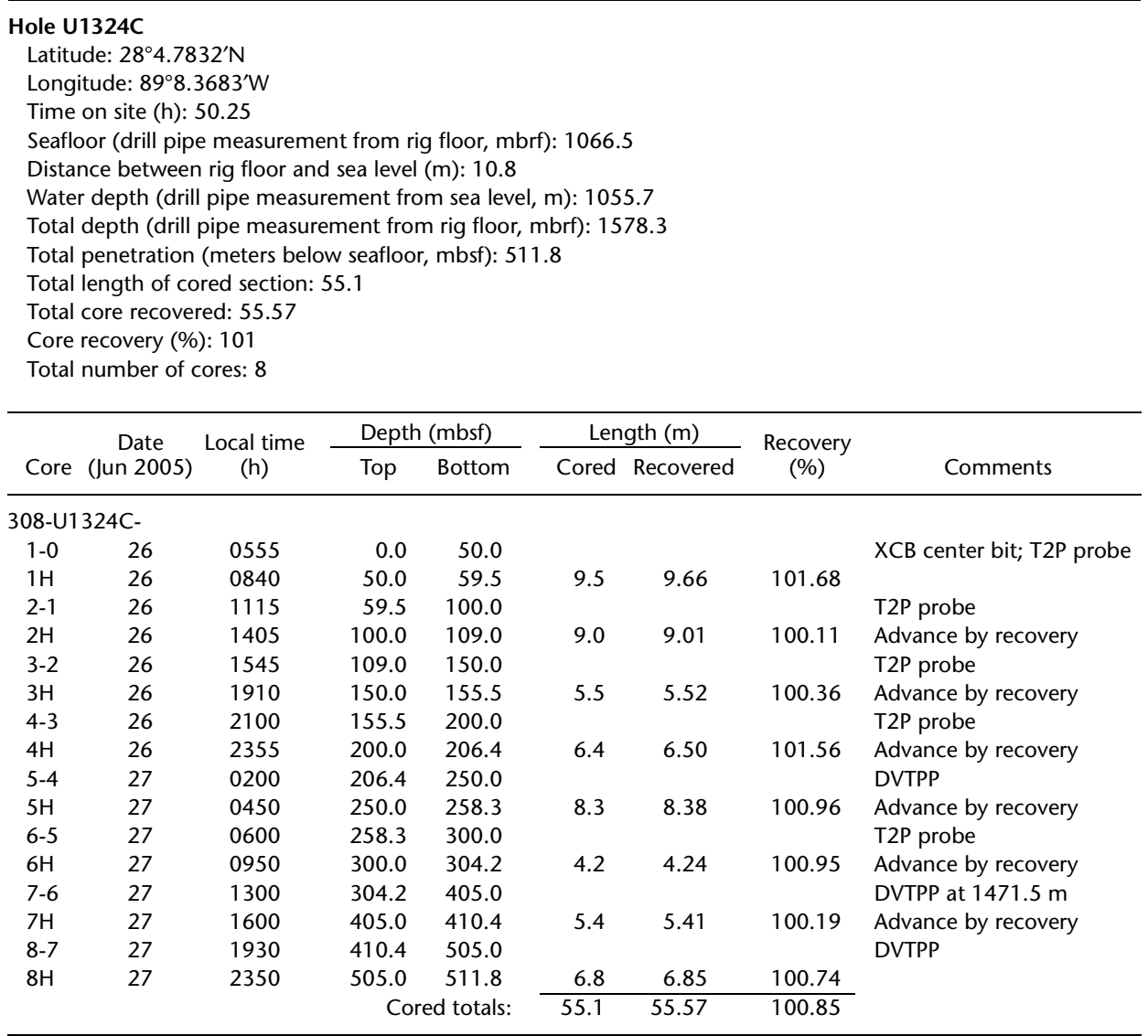

Notes: $\mathrm{XCB}=$ extended core barrel. T2P = pressure/dual pressure probe, DVTPP = Davis-Villinger Temperature-Pressure Probe.

Table T4. Lithostratigraphic units, Hole U1324B.

\begin{tabular}{|c|c|c|c|c|c|}
\hline \multirow[b]{2}{*}{ Unit } & \multicolumn{2}{|l|}{ Top } & \multicolumn{2}{|c|}{ Bottom } & \multirow[b]{2}{*}{$\begin{array}{l}\text { Thickness } \\
\text { (m) }\end{array}$} \\
\hline & $\begin{array}{l}\text { Core, section, } \\
\text { interval }(\mathrm{cm})\end{array}$ & $\begin{array}{l}\text { Depth } \\
\text { (mbsf) }\end{array}$ & $\begin{array}{l}\text { Core, section, } \\
\text { interval }(\mathrm{cm})\end{array}$ & $\begin{array}{l}\text { Depth } \\
\text { (mbsf) }\end{array}$ & \\
\hline I & $\begin{array}{c}\text { 308-U1324B- } \\
1 \mathrm{H}-1,0\end{array}$ & 0.0 & $46 X-2,75$ & 364.7 & 3647 \\
\hline IA & $1 \mathrm{H}-1,0$ & 0.0 & $6 \mathrm{H}-2,53$ & 43.9 & 43.9 \\
\hline IB & $6 \mathrm{H}-2,53$ & 43.9 & $7 \mathrm{H}-6,81$ & 59.7 & 15.8 \\
\hline IC & $7 \mathrm{H}-6,81$ & 59.7 & $12 \mathrm{H}-6,90$ & 107.0 & 47.3 \\
\hline ID & $12 \mathrm{H}-6,90$ & 107.0 & $13 \mathrm{H}-6,80$ & 151.0 & 44.0 \\
\hline IE & $13 \mathrm{H}-6,80$ & 151.0 & $32 \mathrm{H}-1,0$ & 264.6 & 113.6 \\
\hline IF & $32 \mathrm{H}-1,0$ & 264.6 & $34 \mathrm{H}-4,100$ & 288.0 & 23.4 \\
\hline IG & $34 \mathrm{H}-4,100$ & 288.0 & $46 X-2,85$ & 364.7 & 76.7 \\
\hline II & $46 X-2,75$ & 364.7 & $74 X-7,40$ & 608.0 & 243.3 \\
\hline$\| A$ & $46 X-2,85$ & 364.7 & $57 X-1,25$ & 445.5 & 80.8 \\
\hline IIB & $57 X-1,25$ & 445.5 & $60 X-6,60$ & 481.9 & 36.4 \\
\hline IIC & $60 x-6,60$ & 481.9 & $71 X-2,30$ & 581.4 & 99.5 \\
\hline IID & $71 X-2,30$ & 581.4 & $74 X-7,40$ & 608.0 & 26.6 \\
\hline
\end{tabular}


Table T5. Summary of structural measurements, Hole U1324B.

\begin{tabular}{|c|c|c|c|c|c|c|c|}
\hline Unit & $\begin{array}{l}\text { Core, section, } \\
\text { interval }(\mathrm{cm})\end{array}$ & $\begin{array}{l}\text { Depth } \\
\text { (mbsf) }\end{array}$ & $\begin{array}{l}\text { Core strike } \\
\quad\left({ }^{\circ}\right)\end{array}$ & $\begin{array}{l}\text { Reference } \\
\quad \operatorname{dip}\left({ }^{\circ}\right)\end{array}$ & $\begin{array}{l}\text { True strike } \\
\left({ }^{\circ}\right)\end{array}$ & $\begin{array}{l}\text { Reference } \\
\quad \operatorname{dip}\left({ }^{\circ}\right)\end{array}$ & Feature/Remarks \\
\hline \multirow{7}{*}{ IB } & 308-U1324B- & & & & & & \\
\hline & $6 \mathrm{H}-2,53$ & 43.83 & 124 & NA & & & \\
\hline & $6 \mathrm{H}-4,65$ & 46.95 & 60 & 90 & 231 & 30SE & Fault \\
\hline & $6 \mathrm{H}-5,105$ & 48.85 & 60 & NA & & & Fault, dip probably same as one above with same strike \\
\hline & $7 \mathrm{H}-3,25$ & 54.56 & & & & & Possible fault, sediment disrupted \\
\hline & $7 \mathrm{H}-6,60$ & 59.41 & 16 & NA & & & Reverse fault, steep, apparent offset $1 \mathrm{~cm}$ \\
\hline & 7H-6, 81 & 59.62 & & & & & Steep reverse fault, disturbed bedding \\
\hline \multirow{10}{*}{ ID } & $13 \mathrm{H}-1,10-130$ & 108.4-109.6 & 70 & 90 & 320 & $20 \mathrm{SW}$ & Bedding \\
\hline & $13 \mathrm{H}-2,60$ & 110.40 & 75 & 90 & 320 & $15 \mathrm{SW}$ & Bedding \\
\hline & $13 \mathrm{H}-2,80-92$ & $110.6-110.72$ & & & & & $\begin{array}{l}\text { Fault zone, showing some small normal faults (riedel shears?) and } \\
\text { some possible low-angle reverse faults }\end{array}$ \\
\hline & $13 \mathrm{H}-2,110$ & 110.90 & 70 & 90 & 320 & $20 \mathrm{SW}$ & Bedding \\
\hline & $13 \mathrm{H}-3,25-120$ & $111.55-112.0$ & 70 & 90 & 320 & $20 \mathrm{SW}$ & Bedding \\
\hline & $13 \mathrm{H}-4,20$ & 113.00 & 70 & 90 & 320 & $20 \mathrm{SW}$ & Bedding \\
\hline & $13 \mathrm{H}-4,130$ & 114.10 & 66 & 90 & 320 & $24 S W$ & Bedding \\
\hline & $13 \mathrm{H}-5,20$ & 114.50 & 70 & 90 & 320 & $20 \mathrm{SW}$ & Bedding \\
\hline & $13 \mathrm{H}-6,30$ & 114.60 & 70 & 90 & 320 & $20 \mathrm{SW}$ & Bedding \\
\hline & $13 \mathrm{H}-6,80$ & 116.80 & 75 & 90 & 320 & $15 \mathrm{SW}$ & Bedding \\
\hline & $15 \mathrm{H}-2,5-50$ & $128.85-129.3$ & & & & & Normal faults \\
\hline \multirow[t]{2}{*}{ IE } & $21 \mathrm{H}-4,125$ & 184.75 & 110 & NA & & & Reverse fault \\
\hline & $22 \mathrm{H}-1,25$ & 187.15 & 60 & & & & Possible fault \\
\hline \multirow{9}{*}{ IF } & $32 \mathrm{H}-1,40$ & 265.00 & 120 & $52 \mathrm{NE}$ & 332 & $56 \mathrm{NE}$ & Bedding \\
\hline & $32 \mathrm{H}-2,125$ & 267.34 & 140 & 50NE & 319 & $70 \mathrm{NE}$ & Bedding \\
\hline & $32 \mathrm{H}-3,10$ & 267.70 & 125 & NA & & & Bedding \\
\hline & $32 \mathrm{H}-3,20-150$ & $267.8-269.10$ & $\sim 155$ & NA & & & Bedding, small reverse faults in this interval \\
\hline & $34 \mathrm{H}-1,65-100$ & $283.15-283.5$ & & & & & Bedding disrupted \\
\hline & $34 \mathrm{H}-1,15$ & 284.15 & 150 & 90 & 98 & 605 & Bedding \\
\hline & $34 \mathrm{H}-2,22$ & 284.22 & 115 & 90 & 98 & $25 \mathrm{~S}$ & Bedding \\
\hline & $34 \mathrm{H}-4,40$ & 285.90 & 40 & 90 & 98 & $50 \mathrm{~N}$ & Bedding \\
\hline & $34 \mathrm{H}-4,100$ & 288.00 & 90 & 90 & & & Beds horizontal \\
\hline \multirow{2}{*}{ IG } & $37 \mathrm{H}-2,120$ & 307.25 & 50 & $58 \mathrm{NW}$ & 196 & $75 \mathrm{NW}$ & \\
\hline & $39 \mathrm{H}-2,90$ & 321.60 & & & & & Possible fault \\
\hline \multirow{2}{*}{$\mathrm{IIB}$} & $57 X-1,25-75$ & $445.25-445.75$ & & & & & Possible slump fold \\
\hline & $58 \mathrm{X}-59 \mathrm{X}$ & $454.6-473.95$ & & & & & Disruption of layering, mass transport deposit? \\
\hline \multirow{2}{*}{ IID } & $71 X-2,30$ & 581.40 & 65 & $75 \mathrm{~N}$ & & & $\begin{array}{l}\text { Dipping beds, biscuiting causes reversal of orientations in core on }<5 \\
\mathrm{~cm} \text { interval, cannot be oriented }\end{array}$ \\
\hline & $72 X-1,20-130$ & $589.4-590.3$ & & & & & $\begin{array}{l}\text { Deformed zone, possible overturned folds, grain size reversals suggest } \\
\text { overturned beds }\end{array}$ \\
\hline
\end{tabular}

Notes: Orientation convention: strike taken on cut core face, measured in a clockwise direction $0^{\circ}-360^{\circ}$, dip taken from cut core face downward, with direction referred to compass quadrant with north being at top of core. APC cores can be oriented by reference to Tensor tool measurement taken during coring.

Table T6. Relative abundances of benthic foraminifers, Hole U1324B. This table is available in an oversized format. 


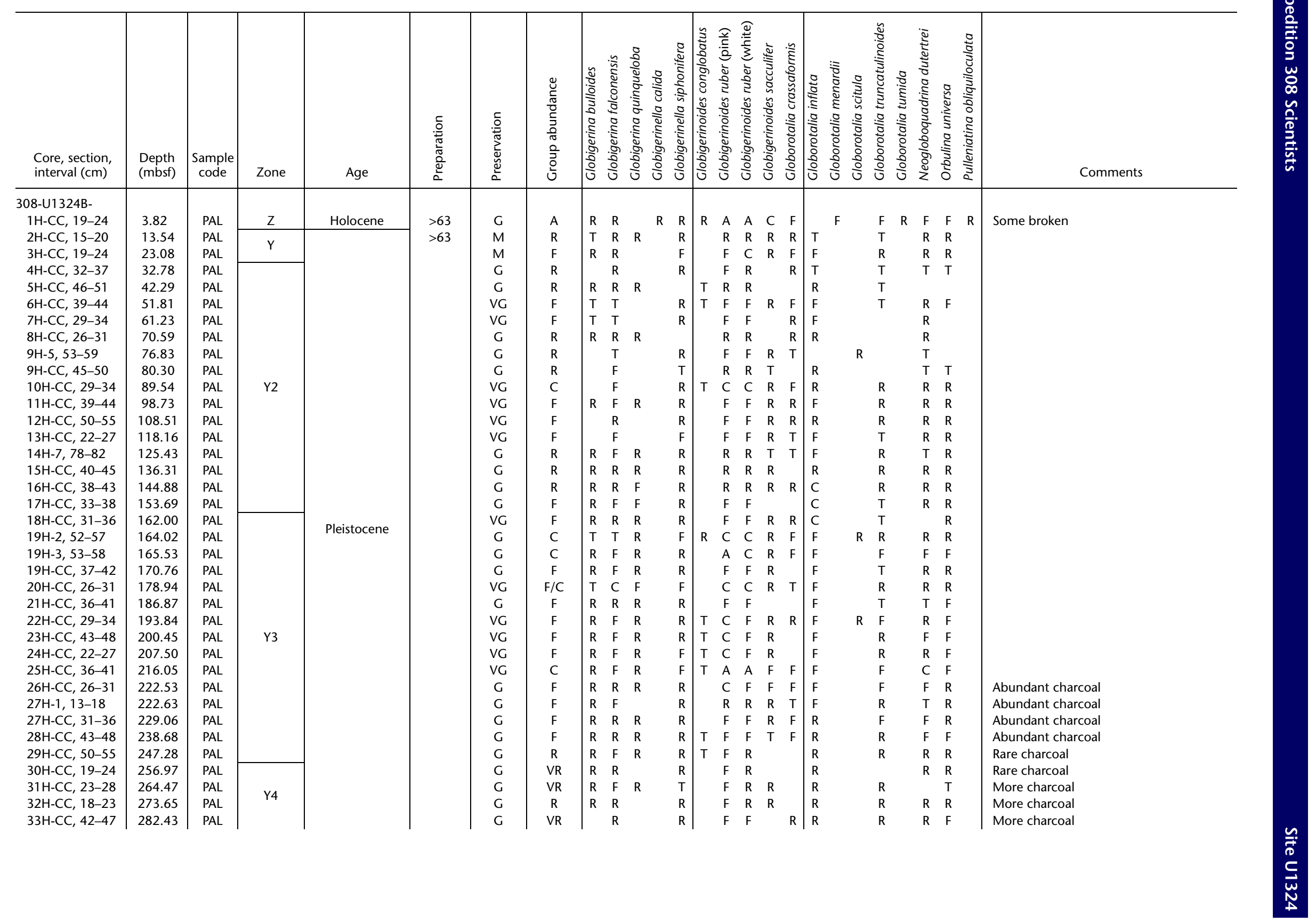



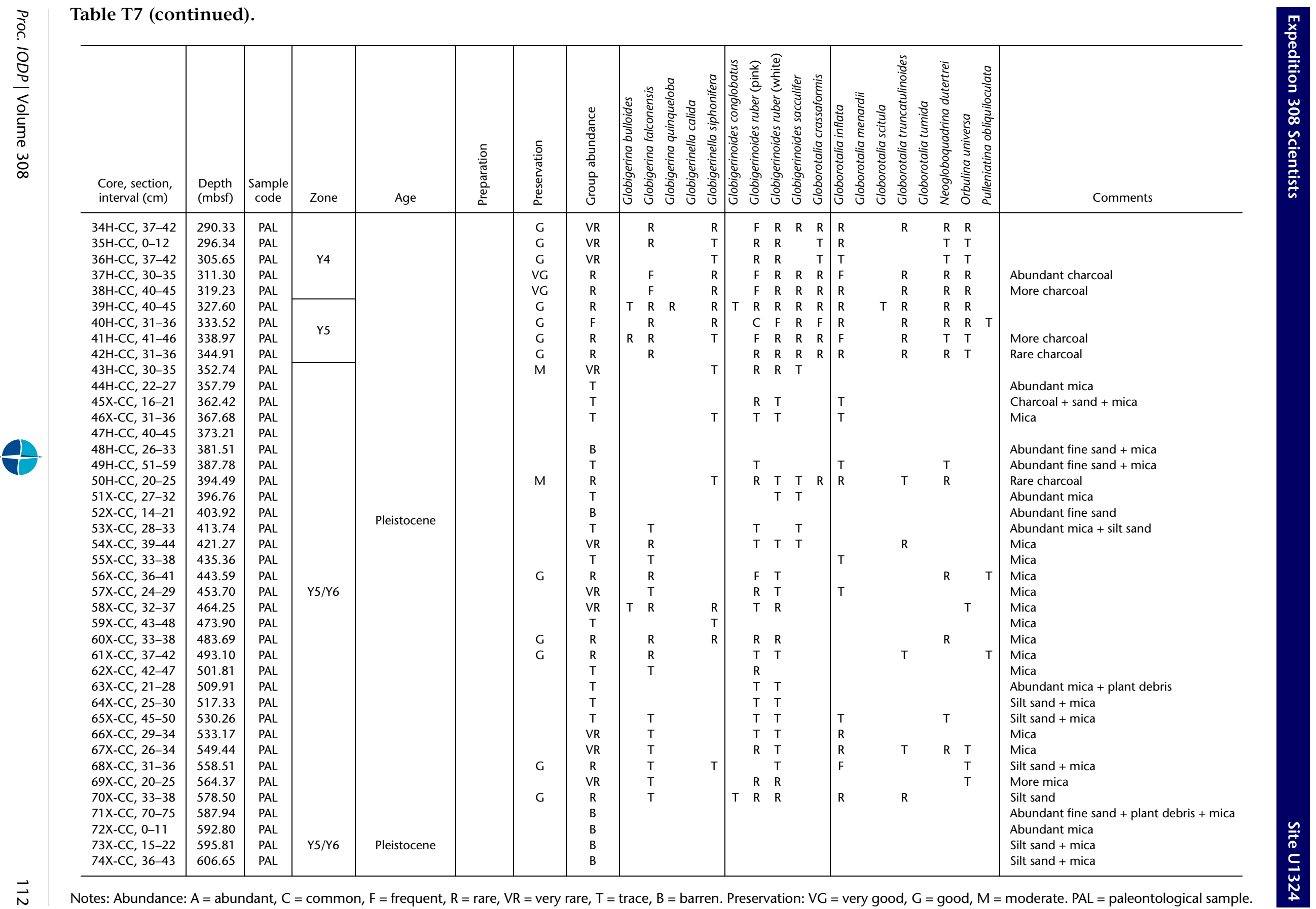
Table T8. Datums used to plot Figure F23, Hole U1324B.

\begin{tabular}{|c|c|c|c|c|c|c|c|c|}
\hline \multirow[b]{2}{*}{ Code } & \multirow[b]{2}{*}{ Event } & \multicolumn{2}{|l|}{ Top } & \multicolumn{2}{|l|}{ Bottom } & \multirow[b]{2}{*}{$\begin{array}{l}\text { Age } \\
(\mathrm{ka})\end{array}$} & \multirow{2}{*}{$\begin{array}{l}\text { Average } \\
\text { depth } \\
\text { (mbsf) }\end{array}$} & \multirow{2}{*}{$\begin{array}{c}\text { Average } \\
\text { sedimentation } \\
\text { rate }(\mathrm{m} / \mathrm{k} . \mathrm{y} .)\end{array}$} \\
\hline & & $\begin{array}{l}\text { Core, section, } \\
\text { interval }(\mathrm{cm})\end{array}$ & $\begin{array}{l}\text { Depth } \\
\text { (mbsf) }\end{array}$ & $\begin{array}{l}\text { Core, section, } \\
\text { interval }(\mathrm{cm})\end{array}$ & $\begin{array}{l}\text { Depth } \\
\text { (mbsf) }\end{array}$ & & & \\
\hline & & 308-U1324B- & & 308-U1324B- & & & & \\
\hline $\mathrm{PF}$ & LO G. inflata & $1 \mathrm{H}-\mathrm{CC}, 15-20$ & 3.80 & $2 \mathrm{H}-\mathrm{CC}, 22-27$ & 13.54 & 10 & 8.65 & 0.86 \\
\hline MS & Tie point 3 & & & & & 26 & 10.00 & \\
\hline $\mathrm{PF}$ & Y2/Y3 boundary & $16 \mathrm{H}-\mathrm{CC}, 38-43$ & 162.00 & $17 \mathrm{H}-\mathrm{CC}, 33-38$ & 164.02 & 24 & 163.00 & 10.00 \\
\hline $\mathrm{PF}$ & Y3/Y4 boundary & $29 \mathrm{H}-\mathrm{CC}, 50-55$ & 247.28 & $30 \mathrm{H}-\mathrm{CC}, 19-24$ & 256.97 & 42 & 252.00 & 5.50 \\
\hline $\mathrm{PF}$ & Y4/Y5 boundary & $38 \mathrm{H}-\mathrm{CC}, 40-45$ & 319.23 & $39 \mathrm{H}-\mathrm{CC}, 40-45$ & 327.60 & 48 & 323.00 & 12.00 \\
\hline MS & Tie point 4 & & & & 470.00 & 52 & 470.00 & \\
\hline $\mathrm{PF}$ & No LO P. obliquiloculata & & & $74 X-C C, 36-43$ & 606.65 & 65 & 606.65 & $>25.00$ \\
\hline
\end{tabular}

Notes: $\mathrm{PF}=$ planktonic foraminifer, $\mathrm{MS}=$ magnetostratigraphy. $\mathrm{LO}=$ last occurrence.

Table T9. Summary of pass-through cryogenic magnetometer measurements, Hole U1324B.

\begin{tabular}{ll}
\hline \multicolumn{1}{c}{ Measurement } & \\
\hline & $308-\mathrm{U} 1324 \mathrm{~B}-$ \\
NRM $(0,10,20,30 \mathrm{mT})$ & $1 \mathrm{H}-1$ through $12 \mathrm{H}-6$ \\
NRM $(0,10,20 \mathrm{mT})$ & $12 \mathrm{H}-7$ through $13 \mathrm{H}-2$ \\
NRM $(0,20 \mathrm{mT})$ & $13 \mathrm{H}-3$ through $25 \mathrm{H}-4$ \\
NRM $(0,10,20 \mathrm{mT})$ & $26 \mathrm{H}-1$ through $74 \mathrm{X}-2$ \\
Fugro cutting shoe & $4 \mathrm{H}, 7 \mathrm{H}, 11 \mathrm{H}, 13 \mathrm{H}, 17 \mathrm{H}, 19 \mathrm{H}, 21 \mathrm{H}, 23 \mathrm{H}, 25 \mathrm{H}, 27 \mathrm{H}, 29 \mathrm{H}, 31 \mathrm{H}, 33 \mathrm{H}, 35 \mathrm{H}, 37 \mathrm{H}, 39 \mathrm{H}, 41 \mathrm{H}, 43 \mathrm{H}, 47 \mathrm{H}$, and $49 \mathrm{H}$ \\
Skipped sections because of core flow-in & $25 \mathrm{H}-5,25 \mathrm{H}-6,28 \mathrm{H}-5,28 \mathrm{H}-6,28 \mathrm{H}-7,32 \mathrm{H}-4,32 \mathrm{H}-5,32 \mathrm{H}-6,35 \mathrm{H}-4,36 \mathrm{H}-5,36 \mathrm{H}-6,38 \mathrm{H}-5,38 \mathrm{H}-6,39 \mathrm{H}-4,39 \mathrm{H}-$ \\
& $5,39 \mathrm{H}-6,43 \mathrm{H}-5,48 \mathrm{H}-6,50 \mathrm{H}-4$, and $50 \mathrm{H}-5$ \\
Skipped sections because of sandy lithology & $37 \mathrm{H}-1$ \\
Skipped sections because of mechanical disturbance & $64 \mathrm{X}-1,64 \mathrm{X}-3$, and all core catchers \\
Tensor tool & $4 \mathrm{H}$ through $50 \mathrm{H}$ \\
\hline
\end{tabular}

Note: $\mathrm{NRM}=$ natural remanent magnetization.

Table T10. Magnetostratigraphic tie points, Site U1324.

\begin{tabular}{lll}
\hline $\begin{array}{c}\text { Magnetostratigraphic } \\
\text { tie point }\end{array}$ & MIS & $\begin{array}{c}\text { Age } \\
\text { (ka) }\end{array}$ \\
\hline MTP1 & $1.1 ?$ & \\
MTP2 & $2.2 ?$ & \\
MTP3 & 3.1 & 30 \\
MTP4 & 3.3 & 52 \\
\hline
\end{tabular}

Note: MIS = marine isotope stage. Corresponding MIS and ages assigned according to Bassinot et al. (1994). 
Table T11. Pore water chemistry, Holes U1324B and U1324C. (Continued on next page.)

\begin{tabular}{|c|c|c|c|c|c|c|c|c|c|c|c|c|c|c|c|c|c|c|c|}
\hline $\begin{array}{l}\text { Core, section, } \\
\text { interval }(\mathrm{cm})\end{array}$ & $\begin{array}{l}\text { Depth } \\
\text { (mbsf) }\end{array}$ & $\begin{array}{l}\text { Alkalinity } \\
(\mathrm{mM})\end{array}$ & $\mathrm{pH}$ & $\begin{array}{l}\text { Salinity } \\
\text { (pph) }\end{array}$ & $\begin{array}{l}\text { Chlorinity } \\
(\mathrm{mM})\end{array}$ & $\begin{array}{l}\mathrm{SO}_{4}^{2-} \\
(\mathrm{mM})\end{array}$ & $\begin{array}{l}\mathrm{NH}_{4}^{+} \\
(\mu \mathrm{M})\end{array}$ & $\begin{array}{l}\mathrm{PO}_{4}^{3-} \\
(\mu \mathrm{M})\end{array}$ & $\begin{array}{l}\mathrm{H}_{4} \mathrm{SiO}_{4} \\
(\mathrm{nM})\end{array}$ & $\begin{array}{l}\mathrm{Na}^{+} \\
(\mathrm{mM})\end{array}$ & $\begin{array}{c}\mathrm{K}^{+} \\
(\mathrm{mM})\end{array}$ & $\begin{array}{l}\mathrm{Mg}^{2+} \\
(\mathrm{mM})\end{array}$ & $\begin{array}{l}\mathrm{Ca}^{2+} \\
(\mathrm{mM})\end{array}$ & $\begin{array}{l}\mathrm{B}^{3+} \\
(\mathrm{nM})\end{array}$ & $\begin{array}{c}\mathrm{Li}^{+} \\
(\mu \mathrm{M})\end{array}$ & $\begin{array}{l}\mathrm{Sr}^{2+} \\
(\mu \mathrm{M})\end{array}$ & $\begin{array}{l}\mathrm{Ba}^{2+} \\
(\mu \mathrm{M})\end{array}$ & $\begin{array}{l}\mathrm{Fe}^{2+} \\
(\mu \mathrm{M})\end{array}$ & $\begin{array}{l}\mathrm{Mn}^{2+} \\
(\mu \mathrm{M})\end{array}$ \\
\hline \multicolumn{20}{|l|}{ 308-U1324B- } \\
\hline $1 \mathrm{H}-2,135-140$ & 2.85 & & & 3.7 & 557 & 30.6 & & & 315 & 467 & 11.3 & 53.3 & 13.2 & 453 & 29.1 & 84.9 & 1.4 & 94.5 & 22.9 \\
\hline $2 \mathrm{H}-1,145-150$ & 5.25 & & & 3.7 & 555 & 27.4 & 1109 & 0.0 & 323 & 432 & 9.7 & 49.7 & 12.7 & 490 & 30.1 & 93.0 & 1.0 & 137.6 & 14.4 \\
\hline $2 \mathrm{H}-3,145-150$ & 8.25 & 5.44 & 6.91 & 3.7 & 558 & 29.6 & 1209 & 3.4 & 430 & 449 & 9.0 & 53.6 & 14.5 & 592 & 35.7 & 109.4 & 0.9 & 435.8 & 14.3 \\
\hline $2 \mathrm{H}-5,135-140$ & 11.15 & & & 3.6 & 564 & 31.0 & 1423 & 0.5 & 463 & 472 & 9.2 & 56.7 & 15.5 & 647 & 36.3 & 117.1 & 0.8 & 458.5 & 15.1 \\
\hline $3 \mathrm{H}-1,145-150$ & 14.75 & 4.99 & 6.80 & 3.7 & 565 & 29.0 & 1698 & 0.0 & 457 & 428 & 7.5 & 52.7 & 14.3 & 677 & 35.8 & 127.5 & 1.2 & 325.5 & 8.3 \\
\hline $3 \mathrm{H}-3,145-150$ & 17.75 & 5.00 & 6.72 & 3.7 & 562 & 33.7 & 1417 & 0.5 & 490 & 490 & 8.0 & 60.6 & 16.9 & 729 & 38.8 & 133.1 & 0.8 & 479.1 & 7.3 \\
\hline $3 \mathrm{H}-5,137-142$ & 20.67 & 5.08 & 6.86 & 3.8 & 564 & 32.4 & 1155 & 0.0 & 515 & 473 & 7.5 & 59.3 & 18.3 & 779 & 41.4 & 137.2 & 0.9 & 433.9 & 7.4 \\
\hline $4 \mathrm{H}-1,145-150$ & 24.25 & 5.42 & 6.70 & 3.8 & 566 & 31.9 & 1758 & 0.0 & 469 & 456 & 6.9 & 56.9 & 17.2 & 838 & 45.2 & 139.2 & 1.7 & 364.4 & 5.6 \\
\hline $4 \mathrm{H}-3,137-142$ & 27.17 & 5.96 & 6.76 & 3.7 & 563 & 36.9 & 2260 & & 494 & 508 & 7.6 & 63.5 & 20.0 & 886 & 49.3 & 141.0 & 1.7 & 427.8 & 6.0 \\
\hline $4 \mathrm{H}-5,145-150$ & 30.25 & 5.70 & 6.67 & 3.8 & 554 & 33.3 & 1483 & 0.5 & 475 & 473 & 7.4 & 58.3 & 19.5 & 903 & 55.0 & 141.2 & 1.2 & 284.3 & 5.8 \\
\hline $5 \mathrm{H}-1,145-150$ & 33.75 & 6.43 & 6.83 & 3.8 & 568 & 37.3 & 1691 & 0.0 & 441 & 525 & 8.0 & 65.2 & 22.7 & 917 & 59.8 & 145.0 & 1.4 & 228.6 & 5.9 \\
\hline $5 \mathrm{H}-3,137-142$ & 36.67 & 6.54 & 7.00 & 3.7 & 562 & 33.2 & 1905 & 2.3 & 481 & 470 & 6.6 & 60.5 & 21.4 & 866 & 58.4 & 138.5 & 1.3 & 216.5 & 7.5 \\
\hline $5 \mathrm{H}-5,145-150$ & 39.75 & 6.74 & 6.78 & 3.8 & 557 & 30.8 & 1329 & 0.0 & 497 & 427 & 5.8 & 55.6 & 20.3 & 881 & 59.3 & 143.1 & 1.1 & 245.3 & 9.0 \\
\hline $6 \mathrm{H}-1,145-150$ & 43.25 & 7.44 & 6.78 & 3.7 & 558 & 33.4 & 1329 & 2.3 & 465 & 491 & 6.7 & 63.3 & 23.6 & 842 & 57.1 & 143.5 & 1.0 & 191.7 & 10.4 \\
\hline $6 \mathrm{H}-3,137-142$ & 46.17 & 6.59 & 6.90 & 3.7 & 559 & 30.3 & 1584 & 2.3 & 411 & 456 & 7.0 & 57.2 & 21.4 & 825 & 56.7 & 136.7 & 1.0 & 61.3 & 9.4 \\
\hline $6 \mathrm{H}-5,145-150$ & 49.25 & 6.02 & 6.79 & 3.8 & 564 & 33.1 & 1738 & 2.3 & 450 & 500 & 7.0 & 63.2 & 24.1 & 822 & 53.3 & 137.9 & 0.9 & 95.9 & 10.5 \\
\hline $7 \mathrm{H}-3,132-142$ & 55.63 & 5.41 & 6.86 & 3.7 & 555 & 28.6 & 1571 & 1.7 & 433 & 495 & 6.8 & 59.7 & 23.5 & 759 & 45.3 & 137.1 & 0.9 & 164.9 & 7.5 \\
\hline $9 \mathrm{H}-3,132-142$ & 74.62 & 4.61 & 6.70 & 3.6 & 561 & 9.1 & 2079 & 1.1 & 431 & 447 & 5.9 & 50.8 & 17.9 & 641 & 33.1 & 123.4 & 1.2 & 191.8 & 7.4 \\
\hline $11 \mathrm{H}-3,140-150$ & 93.70 & 4.83 & 6.59 & 3.4 & 562 & 0.0 & 1925 & 0.5 & 568 & 476 & 5.1 & 50.2 & 19.3 & 666 & 21.5 & 117.4 & 3.1 & 353.6 & 7.5 \\
\hline $13 \mathrm{H}-3,132-142$ & 112.62 & 4.48 & 6.69 & 3.4 & 562 & 0.0 & 2950 & 3.4 & 484 & 446 & 4.4 & 45.9 & 12.0 & 597 & 24.8 & 117.6 & 23.2 & 223.0 & 7.7 \\
\hline $15 \mathrm{H}-3,132-142$ & 131.62 & 5.66 & 6.90 & 3.4 & 561 & 0.0 & 2595 & 0.0 & 506 & 471 & 4.2 & 46.8 & 12.1 & 487 & 13.6 & 105.5 & 10.9 & 229.6 & 5.8 \\
\hline $17 \mathrm{H}-3,132-142$ & 149.22 & 5.09 & 6.86 & 3.3 & 558 & 0.0 & 2796 & 0.0 & 476 & 416 & 4.3 & 42.2 & 9.6 & 477 & 11.1 & 98.7 & 9.9 & 138.2 & 4.6 \\
\hline $19 \mathrm{H}-3,132-142$ & 166.32 & & & 3.3 & 564 & 0.0 & 3010 & 3.4 & 452 & 427 & 5.0 & 42.8 & 10.8 & 467 & 15.4 & 100.5 & 12.7 & 97.8 & 9.1 \\
\hline $21 \mathrm{H}-3,132-142$ & 183.32 & 5.08 & 6.90 & 3.4 & 555 & 0.0 & 3050 & 2.3 & 535 & 503 & 5.3 & 47.3 & 12.8 & 495 & 14.7 & 96.9 & 13.0 & 69.5 & 5.4 \\
\hline $23 \mathrm{H}-3,137-142$ & 198.12 & 5.30 & 6.91 & 3.3 & 563 & 0.0 & 2943 & 1.1 & 601 & 427 & 4.6 & 41.3 & 9.0 & 515 & 15.2 & 89.8 & 13.2 & 228.3 & 6.4 \\
\hline $25 \mathrm{H}-3,140-150$ & 211.90 & 5.46 & 7.01 & 3.4 & 554 & 0.0 & 3559 & 1.1 & 521 & 459 & 5.5 & 46.5 & 8.6 & 541 & 16.1 & 89.2 & 12.7 & 89.5 & 3.5 \\
\hline $27 \mathrm{H}-3,140-150$ & 226.90 & 7.26 & 7.09 & 3.4 & 564 & 0.0 & 3077 & 4.0 & 514 & 480 & 6.0 & 50.2 & 10.7 & 546 & 30.6 & 95.3 & 12.2 & 112.3 & 6.2 \\
\hline $29 \mathrm{H}-3,132-142$ & 242.92 & 4.86 & 7.13 & 3.4 & 558 & 0.0 & 3579 & 0.5 & 391 & 505 & 4.9 & 51.6 & 11.9 & 422 & 15.0 & 103.2 & 10.0 & 54.0 & 3.7 \\
\hline $31 \mathrm{H}-3,140-150$ & 261.20 & 5.48 & 7.02 & 3.3 & 564 & 0.0 & 3693 & 2.3 & 338 & 478 & 4.3 & 48.7 & 11.5 & 461 & 25.7 & 109.8 & 10.2 & 44.0 & 3.4 \\
\hline $33 \mathrm{H}-3,140-150$ & 278.00 & 5.16 & 6.93 & 3.4 & & 0.0 & 3244 & 0.0 & 461 & 435 & 3.5 & 43.1 & 10.5 & 497 & 14.0 & 106.6 & 10.7 & 114.7 & 4.6 \\
\hline $35 \mathrm{H}-3,140-150$ & 293.22 & 5.23 & 7.09 & 3.3 & 556 & 0.0 & 3405 & 0.0 & 426 & 449 & 3.8 & 45.1 & 9.6 & 423 & 18.5 & 99.0 & 12.6 & 48.2 & 4.1 \\
\hline $37 \mathrm{H}-3,140-150$ & 310.00 & 5.92 & 7.01 & 3.3 & 561 & 0.0 & 3921 & 0.0 & 478 & 424 & 3.5 & 42.7 & 7.9 & 415 & 20.9 & 97.8 & 10.8 & 112.8 & 4.8 \\
\hline $39 \mathrm{H}-3,140-150$ & 323.60 & & & & 554 & 0.0 & 4229 & 4.0 & 429 & 447 & 4.2 & 46.6 & 8.3 & 371 & 29.2 & 96.7 & 11.1 & 22.2 & 4.1 \\
\hline $40 \mathrm{H}-3,140-150$ & 332.00 & 5.53 & 7.21 & 3.3 & 559 & 0.0 & 5273 & 4.0 & 276 & 449 & 4.5 & 44.1 & 7.8 & 358 & 26.2 & 93.5 & 9.7 & 12.8 & 3.1 \\
\hline $41 \mathrm{H}-3,132-142$ & 337.82 & & & 3.3 & 560 & 0.0 & 4952 & 2.8 & 393 & 457 & 4.0 & 46.4 & 8.4 & 364 & 18.7 & 98.6 & 9.7 & 33.8 & 3.8 \\
\hline $42 \mathrm{H}-3,140-150$ & 343.40 & 5.75 & 7.18 & 3.4 & 559 & 0.0 & 3740 & 0.0 & 355 & 474 & 4.0 & 48.0 & 9.0 & 366 & 19.3 & 100.8 & 10.4 & 20.1 & 3.4 \\
\hline $43 \mathrm{H}-3,140-150$ & 349.40 & & & & 559 & 0.0 & 3619 & 0.0 & 361 & 428 & 3.6 & 44.7 & 8.1 & 359 & 19.1 & 98.5 & 9.7 & 22.9 & 4.2 \\
\hline $44 \mathrm{H}-2,132-142$ & 355.42 & 5.80 & 7.19 & 3.3 & 562 & 促 & 3586 & 0.0 & 389 & 472 & 3.8 & 47.9 & 9.2 & 379 & 20.2 & 103.4 & 10.8 & 26.2 & 4.1 \\
\hline $45 X-2,140-150$ & 360.80 & 6.20 & 7.10 & 3.4 & 561 & 0.0 & 3947 & 0.0 & 502 & 492 & 3.8 & 50.9 & 9.5 & 419 & 18.2 & 103.3 & 10.8 & 95.5 & 4.2 \\
\hline $46 \mathrm{X}-3,140-150$ & 366.80 & 6.31 & 7.21 & 3.4 & 562 & 0.0 & 4624 & 0.5 & 409 & 450 & 3.8 & 45.5 & 8.7 & 382 & 19.4 & 103.3 & 12.2 & 32.9 & 3.8 \\
\hline $47 \mathrm{H}-3,88-98$ & 371.88 & 6.33 & 7.43 & 3.3 & 563 & 0. & 5092 & 1. & 29 & 475 & 4.0 & 48. & 9.3 & 370 & 25.2 & 102.7 & 12.8 & 11.8 & 4.2 \\
\hline $48 \mathrm{H}-3,140-150$ & 377.60 & 6.16 & 7.57 & 3.3 & 570 & 0.0 & 5400 & 0.0 & 185 & 437 & 4.0 & 42.1 & 8.3 & 351 & 32.1 & 100.0 & 14.1 & 7.8 & 2.8 \\
\hline $49 \mathrm{H}-3,131-141$ & 385.81 & 5.89 & 7.51 & 3.4 & 569 & 0.0 & 5126 & 0.0 & 193 & 464 & 4.2 & 45.3 & 8.7 & 349 & 26.1 & 99.9 & 13.1 & 7.9 & 3.0 \\
\hline $50 \mathrm{H}-3,140-150$ & 392.30 & 6.51 & 7.34 & 3.3 & 564 & 0.0 & 5153 & 0.0 & 312 & 484 & 4.2 & 47.9 & 8.8 & 398 & 20.1 & 104.2 & 12.5 & 7.2 & 3.3 \\
\hline $51 \mathrm{X}-1,140-150$ & 395.90 & & & 3.4 & 562 & 0.0 & 4550 & 4.0 & 398 & 474 & 4.0 & 50.0 & 9.3 & 357 & 26.3 & 103.3 & 12.8 & 7.2 & 3.8 \\
\hline $52 X-3,140-150$ & 401.20 & 7.93 & 7.18 & 3.3 & 561 & 0.0 & 4209 & 0.5 & 444 & 454 & 3.8 & 46.1 & 8.4 & 369 & 30.7 & 104.7 & 12.8 & 35.7 & 3.6 \\
\hline $53 X-3,140-150$ & 410.80 & 8.97 & 7.31 & 3.3 & 563 & 0.0 & 5052 & 1.1 & 379 & 368 & 3.7 & 35.5 & 7.1 & 359 & 18.1 & 98.3 & 14.1 & 70.4 & 4.3 \\
\hline $54 \mathrm{X}-2,140-150$ & 418.90 & 7.63 & 7.48 & 3.3 & 556 & 0.0 & 5226 & 3.4 & 267 & 433 & 4.0 & 44.7 & 8.9 & 311 & 26.9 & 99.3 & 13.0 & 8.1 & 3.9 \\
\hline $55 X-3,140-150$ & 430.10 & & & 3.3 & 557 & 0.0 & 4737 & 1.7 & 360 & 442 & 3.9 & 45.8 & 9.4 & 365 & 19.1 & 99.8 & 9.8 & 28.3 & 4.7 \\
\hline $56 \mathrm{X}-2,132-142$ & 438.12 & 8.24 & 7.60 & 3.3 & 528 & 0.0 & 3981 & 1.7 & 465 & 475 & 4.7 & 48.1 & 11.1 & 395 & 17.0 & 104.5 & 9.8 & 38.1 & 4.4 \\
\hline
\end{tabular}




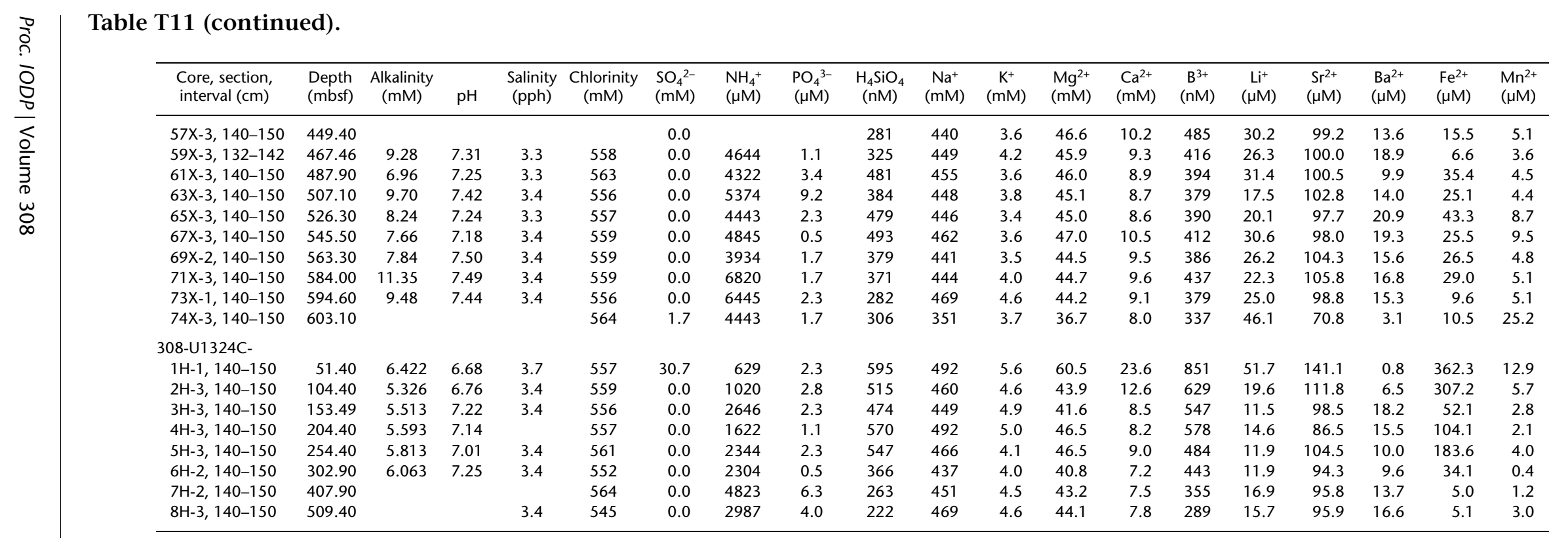


Table T12. Sediment elemental analysis, Holes U1324B and U1324C. (See table note. Continued on next page.)

\begin{tabular}{|c|c|c|c|c|c|c|c|c|}
\hline \multirow{2}{*}{$\begin{array}{l}\text { Core, section, } \\
\text { interval }(\mathrm{cm})\end{array}$} & \multirow{2}{*}{$\begin{array}{l}\text { Depth } \\
\text { (mbsf) }\end{array}$} & \multicolumn{4}{|c|}{ Carbon (wt\%) } & \multirow{2}{*}{$\begin{array}{c}\text { TN } \\
(w t \%)\end{array}$} & \multirow{2}{*}{$\begin{array}{c}\mathrm{TH} \\
\text { (wt\%) }\end{array}$} & \multirow{2}{*}{$\begin{array}{c}\mathrm{C} / \mathrm{N} \\
\text { (mol:mol) }\end{array}$} \\
\hline & & Total & Inorganic & $\mathrm{CaCO}_{3}$ & Organic & & & \\
\hline \multicolumn{9}{|l|}{ 308-U1324B- } \\
\hline $1 \mathrm{H}-1,132-137$ & 1.32 & 1.85 & 0.60 & 5.02 & 1.25 & 0.16 & 0.93 & 9.09 \\
\hline $2 \mathrm{H}-1,145-150$ & 5.25 & 1.93 & 0.79 & 6.61 & 1.14 & 0.18 & 0.86 & 7.47 \\
\hline $2 \mathrm{H}-3,145-150$ & 8.25 & 3.32 & 1.08 & 9.02 & 2.24 & 0.53 & 0.92 & 4.92 \\
\hline $2 \mathrm{H}-5,135-140$ & 11.15 & 2.47 & 0.99 & 8.28 & 1.48 & 0.21 & 1.00 & 8.09 \\
\hline $3 \mathrm{H}-1,145-150$ & 14.75 & 1.83 & 0.90 & 7.47 & 0.93 & 0.16 & 0.87 & 6.85 \\
\hline $3 \mathrm{H}-3,145-150$ & 17.75 & 3.17 & 1.73 & 14.39 & ND & 0.16 & 0.67 & \\
\hline $3 \mathrm{H}-5,137-142$ & 20.67 & 2.82 & 1.85 & 15.39 & 0.97 & 0.18 & 0.71 & 6.32 \\
\hline $4 \mathrm{H}-1,145-150$ & 24.25 & 2.78 & 1.72 & 14.34 & 1.06 & 0.16 & 0.70 & 7.97 \\
\hline $4 \mathrm{H}-3,137-142$ & 27.17 & 2.80 & 1.76 & 14.65 & 1.04 & 0.16 & 0.64 & 7.68 \\
\hline $4 \mathrm{H}-5,145-150$ & 30.25 & 3.33 & 2.37 & 19.72 & 0.96 & 0.17 & 0.61 & 6.63 \\
\hline $5 \mathrm{H}-1,145-150$ & 33.75 & 3.00 & 2.17 & 18.08 & 0.83 & 0.17 & 0.62 & 5.74 \\
\hline $5 \mathrm{H}-3,137-142$ & 36.67 & 2.40 & 1.42 & 11.80 & 0.98 & 0.16 & 0.74 & 7.21 \\
\hline $5 \mathrm{H}-5,145-150$ & 39.75 & 2.56 & 1.54 & 12.85 & 0.00 & 0.15 & 0.80 & 0.00 \\
\hline $6 \mathrm{H}-1,145-150$ & 43.25 & 2.40 & 1.48 & 12.37 & 0.92 & 0.13 & 0.76 & 8.50 \\
\hline $6 \mathrm{H}-3,137-142$ & 46.17 & 2.21 & 1.31 & 10.88 & 0.90 & 0.20 & 0.91 & 5.33 \\
\hline $6 \mathrm{H}-5,145-150$ & 49.25 & 2.77 & 1.95 & 16.20 & 0.82 & 0.19 & 0.80 & 5.07 \\
\hline 7H-3, 132-142 & 55.63 & 2.27 & 1.51 & 12.56 & 0.76 & 0.17 & 0.83 & 5.12 \\
\hline $9 \mathrm{H}-3,132-142$ & 74.62 & 2.26 & 1.51 & 12.58 & 0.75 & 0.17 & 0.68 & 5.19 \\
\hline $11 \mathrm{H}-3,140-150$ & 93.70 & 2.19 & 1.56 & 13.02 & 0.63 & 0.19 & 0.75 & 3.83 \\
\hline $13 \mathrm{H}-3,132-142$ & 112.62 & 2.82 & 2.16 & 17.96 & ND & 0.18 & 0.62 & \\
\hline $15 \mathrm{H}-3,132-142$ & 131.62 & 3.23 & 2.71 & 22.54 & 0.52 & 0.16 & 0.57 & 3.82 \\
\hline $17 \mathrm{H}-3,132-142$ & 149.22 & 3.49 & 2.92 & 24.34 & 0.57 & 0.16 & 0.53 & 4.18 \\
\hline $19 \mathrm{H}-3,132-142$ & 166.32 & 1.28 & 0.72 & 5.98 & 0.56 & 0.18 & 0.89 & 3.60 \\
\hline $21 \mathrm{H}-3,132-142$ & 183.32 & 3.32 & 2.77 & 23.11 & 0.55 & 0.14 & 0.50 & 4.45 \\
\hline $23 \mathrm{H}-3,137-142$ & 198.17 & 3.00 & 2.08 & 17.30 & 0.92 & 0.19 & 0.68 & 5.69 \\
\hline $25 \mathrm{H}-3,140-150$ & 211.90 & 2.86 & 1.95 & 16.28 & 0.91 & 0.19 & 0.59 & 5.70 \\
\hline $27 \mathrm{H}-3,140-150$ & 226.90 & 3.08 & 2.20 & 18.35 & 0.88 & 0.20 & 0.68 & 4.99 \\
\hline $29 \mathrm{H}-3,132-142$ & 242.92 & 3.08 & 2.45 & 20.41 & 0.63 & 0.12 & 0.55 & 6.28 \\
\hline $31 \mathrm{H}-3,140-150$ & 261.20 & 3.27 & 2.61 & 21.74 & 0.66 & 0.12 & 0.54 & 6.38 \\
\hline $33 \mathrm{H}-3,140-150$ & 278.00 & 3.23 & 2.55 & 21.28 & 0.68 & 0.13 & 0.55 & 5.97 \\
\hline $35 \mathrm{H}-2,132-142$ & 293.22 & 3.07 & 2.25 & 18.71 & 0.82 & 0.15 & 0.64 & 6.48 \\
\hline $37 \mathrm{H}-3,140-150$ & 310.00 & 2.96 & 2.10 & 17.46 & 0.86 & 0.15 & 0.65 & 6.53 \\
\hline $39 \mathrm{H}-3,140-150$ & 323.60 & 3.33 & 2.25 & 18.78 & 1.08 & 0.15 & 0.67 & 8.21 \\
\hline $40 \mathrm{H}-3,140-150$ & 332.00 & 3.02 & 2.53 & 21.08 & 0.49 & 0.15 & 0.55 & 3.78 \\
\hline $41 \mathrm{H}-3,132-142$ & 337.82 & 2.53 & 1.87 & 15.60 & 0.66 & 0.11 & 0.67 & 7.21 \\
\hline $42 \mathrm{H}-3,140-150$ & 343.40 & 2.97 & 2.47 & 20.56 & 0.50 & 0.12 & 0.56 & 5.05 \\
\hline $43 \mathrm{H}-3,140-150$ & 349.40 & 2.71 & 2.15 & 17.93 & 0.56 & 0.11 & 0.65 & 5.75 \\
\hline $44 \mathrm{H}-2,132-142$ & 355.42 & 2.77 & 2.20 & 18.30 & 0.57 & 0.12 & 0.61 & 5.78 \\
\hline $45 X-2,140-150$ & 360.80 & 2.23 & 1.29 & 10.71 & 0.94 & 0.12 & 0.75 & 9.24 \\
\hline $46 X-3,140-150$ & 366.80 & 3.11 & 2.63 & 21.90 & 0.48 & 0.15 & 0.57 & 3.63 \\
\hline $47 \mathrm{H}-3,88-98$ & 371.88 & 2.51 & 1.98 & 16.52 & 0.53 & 0.12 & 0.53 & 5.29 \\
\hline $48 \mathrm{H}-3,140-150$ & 377.60 & 2.96 & 2.39 & 19.90 & 0.57 & 0.11 & 0.49 & 6.24 \\
\hline $49 \mathrm{H}-3,131-141$ & 385.81 & 2.80 & 2.35 & 19.54 & 0.45 & 0.11 & 0.49 & 4.69 \\
\hline $50 \mathrm{H}-3,140-150$ & 392.30 & 2.71 & 2.30 & 19.13 & 0.41 & 0.10 & 0.43 & 4.55 \\
\hline $51 X-1,140-150$ & 395.90 & 2.22 & 1.53 & 12.77 & 0.69 & 0.13 & 0.70 & 6.00 \\
\hline $52 X-3,140-150$ & 401.20 & 2.72 & 2.19 & 18.22 & 0.53 & 0.12 & 0.56 & 5.13 \\
\hline $53 X-3,140-150$ & 410.80 & 2.01 & 1.59 & 13.24 & 0.42 & 0.11 & 0.34 & 4.56 \\
\hline $54 \mathrm{X}-2,140-150$ & 418.90 & 2.71 & 2.23 & 18.55 & 0.48 & 0.10 & 0.48 & 5.48 \\
\hline $55 X-3,140-150$ & 430.10 & 2.46 & 1.79 & 14.95 & 0.67 & 0.12 & 0.65 & 6.39 \\
\hline $56 \mathrm{X}-2,132-142$ & 438.12 & 2.58 & 2.00 & 16.65 & 0.58 & 0.11 & 0.58 & 5.88 \\
\hline $57 X-3,140-150$ & 449.40 & 1.38 & 0.75 & 6.22 & 0.63 & 0.12 & 0.64 & 6.37 \\
\hline $59 X-3,132-142$ & 467.46 & 3.08 & 2.32 & 19.35 & 0.76 & 0.12 & 0.68 & 7.16 \\
\hline $61 X-3,140-150$ & 487.90 & 1.43 & 0.99 & 8.28 & 0.44 & 0.12 & 0.67 & 4.18 \\
\hline $63 X-3,140-150$ & 507.10 & 2.28 & 1.62 & 13.52 & 0.66 & 0.11 & 0.61 & 7.24 \\
\hline $65 X-3,140-150$ & 526.30 & 2.35 & 1.77 & 14.72 & 0.58 & 0.12 & 0.59 & 5.84 \\
\hline $67 X-3,140-150$ & 545.50 & 2.36 & 1.92 & 16.00 & 0.44 & 0.14 & 0.54 & 3.65 \\
\hline $69 X-2,140-150$ & 563.30 & 1.14 & 1.89 & 15.71 & ND & 0.16 & 0.60 & \\
\hline $71 X-3,140-150$ & 584.00 & 2.37 & 1.51 & 12.57 & 0.86 & 0.13 & 0.33 & 7.90 \\
\hline $73 X-1,140-150$ & 594.60 & 2.03 & 1.54 & 12.87 & 0.49 & 0.17 & 0.55 & 3.41 \\
\hline
\end{tabular}


Table T12 (continued).

\begin{tabular}{|c|c|c|c|c|c|c|c|c|}
\hline \multirow{2}{*}{$\begin{array}{l}\text { Core, section, } \\
\text { interval }(\mathrm{cm})\end{array}$} & \multirow{2}{*}{$\begin{array}{l}\text { Depth } \\
\text { (mbsf) }\end{array}$} & \multicolumn{4}{|c|}{ Carbon (wt\%) } & \multirow{2}{*}{$\begin{array}{c}\mathrm{TN} \\
(w t \%)\end{array}$} & \multirow{2}{*}{$\begin{array}{c}\text { TH } \\
(w t \%)\end{array}$} & \multirow{2}{*}{$\begin{array}{c}\mathrm{C} / \mathrm{N} \\
\text { (mol:mol) }\end{array}$} \\
\hline & & Total & Inorganic & $\mathrm{CaCO}_{3}$ & Organic & & & \\
\hline $74 X-3,132-142$ & 602.92 & 1.58 & 1.36 & 11.35 & 0.22 & 0.10 & 0.17 & 2.46 \\
\hline \multicolumn{9}{|l|}{ 308-U1324C- } \\
\hline $1 \mathrm{H}-1,140-150$ & 51.50 & 2.53 & 1.54 & 12.86 & 0.99 & 0.17 & 0.38 & 6.73 \\
\hline $2 \mathrm{H}-3,140-150$ & 104.50 & 2.53 & 1.91 & 15.93 & 0.62 & 0.17 & 0.48 & 4.19 \\
\hline $3 \mathrm{H}-3,140-150$ & 153.59 & 3.66 & 3.21 & 26.74 & 0.45 & 0.12 & 0.39 & 4.38 \\
\hline $4 \mathrm{H}-3,140-150$ & 204.50 & 2.67 & 2.10 & 17.51 & 0.57 & 0.17 & 0.27 & 3.86 \\
\hline $5 \mathrm{H}-3,140-150$ & 254.50 & 3.13 & 2.63 & 21.91 & 0.50 & 0.16 & 0.57 & 3.65 \\
\hline $6 \mathrm{H}-2,140-150$ & 303.00 & 2.82 & 2.46 & 20.47 & ND & 0.16 & 0.53 & \\
\hline 7H-2, 140-150 & 408.00 & 1.62 & 1.31 & 10.88 & 0.31 & 0.10 & 0.32 & 3.49 \\
\hline $8 \mathrm{H}-3,140-150$ & 509.50 & 2.19 & 1.78 & 14.85 & 0.41 & 0.14 & 0.52 & 3.46 \\
\hline
\end{tabular}

Note: ND = not detected.

Table T13. Headspace gas analysis, Hole U1324B.

\begin{tabular}{|c|c|c|c|c|c|}
\hline \multirow{2}{*}{$\begin{array}{l}\text { Core, section, } \\
\text { interval }(\mathrm{cm})\end{array}$} & \multirow{2}{*}{$\begin{array}{l}\text { Depth } \\
\text { (mbsf) }\end{array}$} & \multicolumn{3}{|c|}{ Headspace gas (ppmv) } & \multirow{2}{*}{$\begin{array}{l}\mathrm{C}_{1} / \mathrm{C}_{2} \\
\text { ratio }\end{array}$} \\
\hline & & Methane & Ethane & Ethylene & \\
\hline \multicolumn{6}{|l|}{ 308-U1324B- } \\
\hline $1 \mathrm{H}-2,0-5$ & 1.5 & 1.7 & 0.0 & 0.0 & \\
\hline $2 \mathrm{H}-6,0-5$ & 11.3 & 1.7 & 0.0 & 0.0 & \\
\hline $3 \mathrm{H}-6,0-5$ & 20.8 & 1.8 & 0.0 & 0.0 & \\
\hline $4 \mathrm{H}-6,0-5$ & 30.3 & 4.0 & 0.0 & 0.0 & \\
\hline $5 \mathrm{H}-6,0-5$ & 39.8 & 2.0 & 0.0 & 0.0 & \\
\hline $6 \mathrm{H}-6,0-5$ & 49.3 & 1.9 & 0.0 & 0.0 & \\
\hline $7 \mathrm{H}-6,0-5$ & 58.8 & 1.5 & 0.0 & 0.0 & \\
\hline $8 \mathrm{H}-6,0-5$ & 68.3 & 1.7 & 0.0 & 0.0 & \\
\hline $9 \mathrm{H}-4,0-5$ & 74.8 & 1.6 & 0.0 & 0.0 & \\
\hline $10 \mathrm{H}-6,0-5$ & 87.3 & 1.7 & 0.0 & 0.0 & \\
\hline $11 \mathrm{H}-4,0-5$ & 93.8 & 9.9 & 0.0 & 0.0 & \\
\hline $12 \mathrm{H}-4,0-5$ & 103.3 & 123.1 & 0.0 & 0.0 & \\
\hline $13 \mathrm{H}-4,0-5$ & 112.8 & 752.8 & 0.0 & 0.0 & \\
\hline $14 \mathrm{H}-5,0-5$ & 121.7 & 3,062 & 0.9 & 0.0 & 3,402 \\
\hline $15 \mathrm{H}-4,0-5$ & 131.8 & 3,109 & 0.0 & 0.8 & \\
\hline $16 \mathrm{H}-4,0-5$ & 139.7 & 383.9 & 0.0 & 0.0 & \\
\hline $17 \mathrm{H}-4,0-5$ & 149.4 & 212.2 & 0.0 & 0.0 & \\
\hline $18 \mathrm{H}-5,0-5$ & 159.7 & 148.5 & 0.0 & 0.0 & \\
\hline $19 \mathrm{H}-4,0-5$ & 166.5 & 8,905 & 0.0 & 0.0 & \\
\hline $20 \mathrm{H}-5,0-5$ & 176.8 & 14,174 & 2.3 & 0.0 & 6,163 \\
\hline $21 \mathrm{H}-4,0-5$ & 183.5 & 1,302 & 0.0 & 0.0 & \\
\hline $22 \mathrm{H}-4,0-5$ & 191.4 & 3,154 & 0.0 & 0.0 & \\
\hline $23 \mathrm{H}-4,0-5$ & 198.3 & 1,360 & 0.0 & 0.0 & \\
\hline $24 \mathrm{H}-4,0-5$ & 204.9 & 39,540 & 4.2 & 0.0 & 9,414 \\
\hline $25 \mathrm{H}-4,0-5$ & 212.0 & 40,340 & 4.0 & 0.0 & 10,085 \\
\hline $26 \mathrm{H}-4,0-5$ & 220.6 & 13,664 & 1.5 & 0.0 & 9,109 \\
\hline $27 \mathrm{H}-4,0-5$ & 227.0 & 6,437 & 0.0 & 0.0 & \\
\hline $28 \mathrm{H}-4,0-5$ & 233.6 & 382.3 & 0.0 & 0.0 & \\
\hline $29 \mathrm{H}-3,0-5$ & 241.6 & 32,062 & 3.1 & 0.0 & 10,342 \\
\hline $30 \mathrm{H}-4,0-5$ & 251.8 & 37,786 & 2.6 & 0.0 & 14,533 \\
\hline $31 \mathrm{H}-4,0-5$ & 261.3 & 41,621 & 3.5 & 0.0 & 11,892 \\
\hline $32 \mathrm{H}-4,0-5$ & 269.1 & 6,586 & 0.0 & 0.0 & \\
\hline $33 \mathrm{H}-4,0-5$ & 278.1 & 3,527 & 0.0 & 0.0 & \\
\hline $34 \mathrm{H}-3,0-5$ & 285.5 & 1,575 & 0.0 & 0.0 & \\
\hline
\end{tabular}

\begin{tabular}{|c|c|c|c|c|c|}
\hline \multirow{2}{*}{$\begin{array}{l}\text { Core, section, } \\
\text { interval (cm) }\end{array}$} & \multirow{2}{*}{$\begin{array}{l}\text { Depth } \\
\text { (mbsf) }\end{array}$} & \multicolumn{3}{|c|}{ Headspace gas (ppmv) } & \multirow{2}{*}{$\begin{array}{l}\mathrm{C}_{1} / \mathrm{C}_{2} \\
\text { ratio }\end{array}$} \\
\hline & & Methane & Ethane & Ethylene & \\
\hline $35 \mathrm{H}-3,0-5$ & 293.4 & 1,371 & 0.0 & 0.0 & \\
\hline $36 \mathrm{H}-5,0-5$ & 302.4 & 647.0 & 0.0 & 0.0 & \\
\hline $37 \mathrm{H}-4,0-5$ & 310.1 & 592.3 & 0.0 & 0.0 & \\
\hline $38 \mathrm{H}-5,0-5$ & 317.3 & 13,613 & 0.9 & 0.0 & 15,125 \\
\hline $39 \mathrm{H}-4,0-5$ & 323.7 & 6,046 & 0.0 & 0.0 & \\
\hline $40 \mathrm{H}-4,0-5$ & 332.1 & 17,041 & 0.0 & 0.0 & \\
\hline $41 \mathrm{H}-4,0-5$ & 338.0 & 5,006 & 0.0 & 0.0 & \\
\hline $42 \mathrm{H}-4,0-5$ & 343.5 & 5,231 & 0.0 & 0.0 & \\
\hline $43 \mathrm{H}-4,0-5$ & 349.5 & 5,563 & 0.0 & 0.0 & \\
\hline $44 \mathrm{H}-3,0-5$ & 355.6 & 4,387 & 0.0 & 0.0 & \\
\hline $45 X-3,0-5$ & 360.9 & 3,965 & 0.0 & 0.0 & \\
\hline $46 X-3,0-5$ & 365.4 & 3,239 & 0.0 & 0.0 & \\
\hline $47 \mathrm{H}-4,0-5$ & 372.0 & 6,949 & 0.0 & 0.0 & \\
\hline $48 \mathrm{H}-4,0-5$ & 377.7 & 7,597 & 0.0 & 0.0 & \\
\hline $49 \mathrm{H}-4,0-5$ & 385.9 & 14,277 & 0.0 & 0.0 & \\
\hline $50 \mathrm{H}-4,0-5$ & 392.4 & 4,754 & 0.0 & 0.0 & \\
\hline $51 \times-2,0-5$ & 396.0 & 7,007 & 0.0 & 0.0 & \\
\hline $52 X-4,0-5$ & 401.3 & 4,311 & 0.0 & 0.0 & \\
\hline $53 X-4,0-5$ & 410.9 & 4,662 & 0.0 & 0.0 & \\
\hline $54 X-3,0-5$ & 419.0 & 5,060 & 0.0 & 0.0 & \\
\hline $55 X-4,0-5$ & 430.2 & 3,526 & 0.0 & 0.0 & \\
\hline $56 X-4,0-5$ & 439.8 & 4,703 & 0.0 & 0.0 & \\
\hline $57 X-4,0-5$ & 449.5 & 5,716 & 0.0 & 0.0 & \\
\hline $58 \times-5,0-5$ & 460.6 & 2,789 & 0.0 & 0.0 & \\
\hline $59 X-4,0-5$ & 467.6 & 10,949 & 0.0 & 0.0 & \\
\hline $60 \times-4,0-5$ & 478.4 & 4,795 & 0.0 & 0.5 & \\
\hline $61 X-5,0-5$ & 489.5 & 3,567 & 0.0 & 0.0 & \\
\hline $62 X-4,0-5$ & 497.5 & 10,451 & 0.0 & 0.0 & \\
\hline $63 X-4,0-5$ & 507.2 & 7,390 & 0.0 & 0.0 & \\
\hline $65 X-4,0-5$ & 526.4 & 5,834 & 0.0 & 0.0 & \\
\hline $67 X-4,0-5$ & 545.6 & 2,021 & 0.0 & 0.0 & \\
\hline $68 X-5,0-5$ & 556.7 & 3,297 & 0.0 & 0.0 & \\
\hline $69 X-3,0-5$ & 563.4 & 8,898 & 0.0 & 0.0 & \\
\hline $70 X-4,0-5$ & 574.5 & 4,921 & 0.0 & 0.0 & \\
\hline $71 X-4,0-5$ & 584.1 & 13,244 & 0.0 & 0.0 & \\
\hline $72 X-3,0-5$ & 592.2 & 13,653 & 1.4 & 1.5 & 9,752 \\
\hline $73 X-2,0-5$ & 594.7 & 12,016 & 0.0 & 0.0 & \\
\hline $74 X-4,0-5$ & 603.1 & 14,071 & 0.7 & 0.0 & 20,102 \\
\hline
\end{tabular}


Table T14. Samples for microbiology, Hole U1324B.

\begin{tabular}{|c|c|c|}
\hline $\begin{array}{l}\text { Core, section, } \\
\text { interval }(\mathrm{cm})\end{array}$ & $\begin{array}{l}\text { Cell density } \\
\text { (cells } / \mathrm{mL} \text { ) }\end{array}$ & Comments \\
\hline \multicolumn{3}{|l|}{ 308-U1324B- } \\
\hline $1 \mathrm{H}-2,2.9-3.0$ & $2.0 \times 10^{5}$ & \\
\hline $2 \mathrm{H}-2,6.7-6.8$ & $3.3 \times 10^{4}$ & \\
\hline $2 \mathrm{H}-5,11.2-11.3$ & $1.5 \times 10^{5}$ & \\
\hline $3 \mathrm{H}-2,16.2-16.3$ & $6.6 \times 10^{4}$ & \\
\hline $3 \mathrm{H}-5,20.7-20.8$ & $2.5 \times 10^{4}$ & \\
\hline $4 \mathrm{H}-3,27.2-27.3$ & $2.5 \times 10^{4}$ & \\
\hline $5 \mathrm{H}-3,36.7-36.8$ & $1.9 \times 10^{4}$ & \\
\hline $6 \mathrm{H}-3,46.2-46.3$ & ND & \\
\hline $7 \mathrm{H}-3,55.7-55.8$ & $1.5 \times 10^{4}$ & \\
\hline $8 \mathrm{H}-3,65.2-65.3$ & $1.0 \times 10^{4}$ & \\
\hline $9 \mathrm{H}-3,74.7-74.8$ & ND & \\
\hline $10 \mathrm{H}-3,84.2-84.3$ & $1.0 \times 10^{4}$ & \\
\hline $11 \mathrm{H}-3,93.7-93.8$ & ND & \\
\hline $13 \mathrm{H}-3,112.7-112.8$ & ND & \\
\hline $15 \mathrm{H}-3,131.7-131.8$ & $2.8 \times 10^{4}$ & \\
\hline $17 \mathrm{H}-3,149.3-149.4$ & ND & \\
\hline $19 \mathrm{H}-3,166.4-166.5$ & ND & \\
\hline $21 \mathrm{H}-3,183.4-183.5$ & ND & \\
\hline $23 \mathrm{H}-3,198.2-198.3$ & ND & \\
\hline $26 \mathrm{H}-3,220.5-220.6$ & ND & \\
\hline $29 \mathrm{H}-3,243.0-243.1$ & ND & \\
\hline $32 \mathrm{H}-3,269.0-269.1$ & ND & \\
\hline $35 \mathrm{H}-2,293.3-293.4$ & ND & \\
\hline $38 \mathrm{H}-3,315.7-315.8$ & ND & \\
\hline $41 \mathrm{H}-3,337.9-338.0$ & ND & \\
\hline $44 \mathrm{H}-2,355.5-355.6$ & ND & \\
\hline $48 \mathrm{H}-3,377.6-377.7$ & ND & No contamination test \\
\hline $50 \mathrm{H}-3,392.2-392.3$ & ND & \\
\hline $53 X-3,410.7-410.8$ & ND & \\
\hline $56 \mathrm{X}-2,438.2-438.3$ & ND & \\
\hline $59 X-3,467.6-467.6$ & ND & \\
\hline $64 X-3,515.6-515.6$ & ND & \\
\hline $66 \mathrm{X}-1,532.8-532.9$ & ND & \\
\hline $68 X-4,556.6-556.7$ & ND & \\
\hline $70 X-3,574.4-574.5$ & ND & \\
\hline $72 X-2,592.1-592.2$ & ND & \\
\hline $74 X-3,603.02-603.1$ & ND & No contamination test \\
\hline
\end{tabular}

Note: ND = not detected or below significant levels. 
Table T15. Check shot stack summary, Hole U1324A.

Gun azimuth: 0

Gun offset: 49

Gun depth from Schlumberger zero $(\mathrm{m}): 12.6$

Hydrophone depth from Schlumberger zero $(\mathrm{m}): 12.6$

SRD from Schlumberger zero $(\mathrm{m}): 10.6$

Water depth (meters below rig floor, mbrf): 1066.1

Other check shot constants:

True vertical time correction: yes

Surface velocity $(\mathrm{m} / \mathrm{s}): 1524.0$

\begin{tabular}{ccccccr}
\hline $\begin{array}{c}\text { Stack } \\
\text { number }\end{array}$ & $\begin{array}{c}\text { Measured } \\
\text { depth } \\
(\mathrm{mbrf})\end{array}$ & $\begin{array}{c}\text { Shots } \\
\text { stacked } \\
(\mathrm{N})\end{array}$ & $\begin{array}{c}\text { Measured } \\
\text { transit time } \\
(\mathrm{ms})\end{array}$ & $\begin{array}{c}\text { True } \\
\text { vertical } \\
\text { depth from } \\
\text { SRD (mbsl) }\end{array}$ & $\begin{array}{c}\text { Corrected } \\
\text { two-way } \\
\text { traveltime } \\
(\mathrm{ms})\end{array}$ & $\begin{array}{c}\text { Interval } \\
\text { velocity } \\
(\mathrm{m} / \mathrm{s})\end{array}$ \\
\hline 16 & 1149.9 & 5 & 759.84 & 1139.3 & 1520.90 & 1582.64 \\
15 & 1177.0 & 5 & 776.95 & 1166.4 & 1555.15 & 1602.26 \\
14 & 1220.0 & 5 & 803.76 & 1209.4 & 1608.82 & 1654.27 \\
13 & 1250.0 & 5 & 821.88 & 1239.4 & 1645.09 & 1689.34 \\
12 & 1275.5 & 5 & 836.96 & 1264.9 & 1675.28 & 1642.15 \\
11 & 1300.0 & 5 & 851.87 & 1289.4 & 1705.12 & 1596.43 \\
10 & 1325.0 & 7 & 867.51 & 1314.4 & 1736.44 & 1645.45 \\
9 & 1350.0 & 9 & 882.69 & 1339.4 & 1766.83 & 1702.81 \\
8 & 1375.1 & 9 & 897.42 & 1364.5 & 1796.31 & 1708.40 \\
7 & 1400.0 & 9 & 911.99 & 1389.4 & 1825.46 & 1688.26 \\
6 & 1425.1 & 9 & 926.84 & 1414.5 & 1855.19 & 1777.93 \\
5 & 1449.9 & 9 & 940.78 & 1439.3 & 1883.09 & 1802.80 \\
4 & 1495.0 & 9 & 965.78 & 1484.4 & 1933.12 & 1827.46 \\
3 & 1520.0 & 7 & 979.45 & 1509.4 & 1960.49 & 1832.37 \\
2 & 1544.9 & 9 & 993.03 & 1534.3 & 1987.66 & 1851.97 \\
1 & 1565.0 & 9 & 1003.87 & 1554.4 & 2009.37 & 0.00 \\
\hline
\end{tabular}

Note: SRD = seismic reference depth . 
Table T16. Downhole tool deployment, Site U1324.

\begin{tabular}{|c|c|c|c|c|c|c|}
\hline \multirow[b]{2}{*}{ Hole } & \multirow[b]{2}{*}{ Tool } & \multirow[b]{2}{*}{ Deployment } & \multicolumn{2}{|c|}{ Depth } & \multirow{2}{*}{$\begin{array}{l}\text { Date } \\
\text { (Jun } \\
2005 \text { ) }\end{array}$} & \multirow{2}{*}{$\begin{array}{l}\text { Time in } \\
\text { formation } \\
\text { (min) }\end{array}$} \\
\hline & & & $(\mathrm{mbsf})$ & $(m b s l)$ & & \\
\hline \multicolumn{7}{|l|}{ 308- } \\
\hline U1324B & $\mathrm{T} 2 \mathrm{P}$ & 5 & 51.3 & 1108.1 & 21 & 30 \\
\hline U1324B & $\mathrm{T} 2 \mathrm{P}$ & 6 & 89.3 & 1146.1 & 21 & 30 \\
\hline U1324B & $\mathrm{T} 2 \mathrm{P}$ & 7 & 117.8 & 1174.6 & 21 & 40 \\
\hline U1324B & $\mathrm{T} 2 \mathrm{P}$ & 8 & 136.3 & 1193.1 & 21 & 30 \\
\hline U1324B & $\mathrm{T} 2 \mathrm{P}$ & 9 & 368.0 & 1424.8 & 23 & 40 \\
\hline U1324B & $\mathrm{T} 2 \mathrm{P}$ & 10 & 394.5 & 1451.3 & 23 & 30 \\
\hline U1324B & $\mathrm{T} 2 \mathrm{P}$ & 11 & 593.2 & 1650.0 & 25 & 15 \\
\hline U1324C & $\mathrm{T} 2 \mathrm{P}$ & 12 & 50.0 & 1105.7 & 26 & 60 \\
\hline U1324C & $\mathrm{T} 2 \mathrm{P}$ & 13 & 100.0 & 1155.7 & 26 & 60 \\
\hline U1324C & $\mathrm{T} 2 \mathrm{P}$ & 14 & 150.0 & 1205.7 & 26 & 60 \\
\hline U1324C & $\mathrm{T} 2 \mathrm{P}$ & 15 & 200.0 & 1255.7 & 27 & 60 \\
\hline U1324C & $\mathrm{T} 2 \mathrm{P}$ & 16 & 300.0 & 1355.7 & 27 & 90 \\
\hline U1324B & DVTPP & 3 & 229.1 & 1285.9 & 22 & 40 \\
\hline U1324B & DVTPP & 4 & 362.4 & 1419.2 & 23 & 40 \\
\hline U1324B & DVTPP & 5 & 387.9 & 1444.7 & 23 & 10 \\
\hline U1324B & DVTPP & 6 & 464.3 & 1521.1 & 24 & 30 \\
\hline U1324B & DVTPP & 7 & 493.1 & 1549.9 & 24 & 30 \\
\hline U1324B & DVTPP & 8 & 521.9 & 1578.7 & 24 & 25 \\
\hline U1324B & DVTPP & 9 & 541.1 & 1597.9 & 25 & 30 \\
\hline U1324B & DVTPP & 10 & 560.4 & 1617.2 & 25 & 30 \\
\hline U1324B & DVTPP & 11 & 589.2 & 1646.0 & 25 & 45 \\
\hline U1324B & DVTPP & 12 & 608.2 & 1665.0 & 25 & 60 \\
\hline U1324C & DVTPP & 13 & 250.0 & 1305.7 & 27 & 90 \\
\hline U1324C & DVTPP & 14 & 405.0 & 1460.7 & 27 & 90 \\
\hline U1324C & DVTPP & 15 & 505.0 & 1560.7 & 28 & 90 \\
\hline U1324B & APCT & 2 & 51.3 & 1108.1 & 21 & 10 \\
\hline U1324B & APCT & 3 & 79.8 & 1136.6 & 21 & 10 \\
\hline U1324B & APCT & 4 & 108.3 & 1165.1 & 21 & 10 \\
\hline U1324B & APCT & 5 & 136.3 & 1193.1 & 21 & 10 \\
\hline
\end{tabular}

Note: $\mathrm{T} 2 \mathrm{P}=$ temperature/dual pressure probe, DVTPP = Davis-Villinger Temperature-Pressure Probe, APCT = advanced piston corer temperature tool. 
Table T17. Event summary of T2P Deployment 5, Hole U1324B.

\begin{tabular}{rrl}
\hline & Time & \\
Event & $($ CDT $)$ & \\
\hline 1 & & Data logger started at 1 Hz \\
2 & 0640 & T2P on rig floor \\
3 & 0647 & Pressure response chamber removed from T2P tip \\
4 & 0647 & Shroud in place over T2P tip \\
5 & 0648 & T2P connected to spacer \\
6 & 0650 & CDS connected to spacer \\
7 & 0655 & Start lowering T2P downhole, pumps on \\
8 & 0704 & Stop at 515 mbsl, pumps off \\
9 & 0708 & Start lowering probe, pumps on \\
10 & 0712 & Stop at 768 mbsl, pumps off \\
11 & 0714 & Start lowering probe, pumps on \\
12 & 0719 & Stop at 1066 mbsl, pumps off \\
13 & 0722 & Start lowering probe, pumps on at 18 spm \\
14 & 0723 & Bit is 0.5 $\mathrm{m}$ off BOH \\
15 & 0724 & Start lowering probe to land in BHA \\
16 & 0725 & CDS lands in BHA; pumps off \\
17 & 0725 & Raising BHA to 2 m off BOH \\
18 & 0726 & Start penetration of T2P into sediment, 2 m advance of BHA \\
19 & 0727 & End of T2P penetration; bit 0.25 m off bottom of hole \\
20 & 0727 & Raising BHA 2 m off bottom of hole \\
21 & 0732 & Pumping at 11 spm \\
22 & 0757 & Pulling T2P uphole slowly with wireline \\
23 & 0758 & CDS clear of BHA \\
24 & 0800 & Stop at 1067 mbsl, pumps off \\
25 & 0804 & Pulling T2P uphole slowly with wireline \\
26 & 0809 & Stop at 767 mbsl, pumps off \\
27 & 0811 & Pulling T2P uphole slowly with wireline \\
28 & 0815 & Stop at 516 mbsl, pumps off \\
29 & 0817 & Pulling T2P uphole slowly with wireline \\
30 & 0825 & Wireline disconnected from CDS \\
31 & 0825 & CDS extended \\
32 & 0828 & CDS disconnected from spacer \\
33 & 0828 & Spacer disconnected from CDS \\
35 & 0830 & T2P disconnected from spacer \\
36 & & Data downloaded from data logger \\
\hline & &
\end{tabular}

Notes: Depth $=51.3$ mbsf. Date $=21$ June 2005. T2P $=$ temperature/dual pressure probe CDS $=$ colleted delivery system. $\mathrm{BHA}=$ bottom-hole assembly. $\mathrm{CDT}=$ central daylight time. $\mathrm{SPM}=$ strokes per minute. $\mathrm{BOH}=$ bottom of hole. 
Table T18. Event summary of T2P Deployment 6, Hole U1324B.

\begin{tabular}{rcl}
\hline & Time & \\
Event & (CDT) & \\
\hline 1 & $09: 17: 00$ & Data logger started at 1 Hz \\
2 & $11: 15: 19$ & T2P on rig floor \\
3 & $11: 47: 09$ & Start lowering T2P downhole, pumps on \\
4 & $11: 56: 03$ & Stop at 511 mbsl, pumps off \\
5 & $11: 57: 57$ & Start lowering probe, pumps on \\
6 & $12: 03: 05$ & Stop at 761 mbsl, pumps off \\
7 & $12: 04: 57$ & Start lowering probe, pumps on \\
8 & $12: 10: 14$ & Stop at 1058 mbsl, pumps off \\
9 & $12: 16: 30$ & Start lowering probe \\
10 & $12: 18: 50$ & Stop at 1135 mbsl, pumps off \\
11 & $12: 20: 54$ & Start lowering probe to land in BHA \\
12 & $12: 22: 56$ & CDS lands in BHA; pumps off \\
13 & $12: 31: 02$ & Start penetration of T2P into sediment \\
14 & $12: 33: 43$ & End of T2P penetration; bit 1 m off bottom of hole \\
15 & $12: 36: 02$ & Raising BHA 2 m off bottom of hole \\
16 & $12: 42: 09$ & Pumping at 11 spm \\
17 & $13: 08: 17$ & Pulling T2P uphole slowly with wireline \\
18 & $13: 11: 30$ & CDS clear of BHA \\
19 & $13: 13: 40$ & Stop at 1058 mbsl, pumps off \\
20 & $13: 15: 47$ & Pulling T2P uphole slowly with wireline \\
21 & $13: 18: 55$ & Stop at 760 mbsl, pumps off \\
22 & $13: 20: 52$ & Pulling T2P uphole slowly with wireline \\
23 & $13: 23: 50$ & Stop at 511 mbsl, pumps off \\
24 & $13: 25: 46$ & Pulling T2P uphole slowly with wireline \\
25 & $13: 31: 24$ & Wireline disconnected from CDS \\
26 & $13: 32: 30$ & CDS retracted \\
27 & $13: 35: 22$ & CDS disconnected from spacer \\
28 & $13: 37: 31$ & Spacer disconnected from CDS \\
29 & $13: 38: 23$ & T2P out of pipe \\
30 & $13: 50: 30$ & Data downloaded from data logger \\
\hline & & \\
& & \\
& & \\
13 &
\end{tabular}

Notes: Depth $=89.3$ mbsf. Date $=21$ June 2005. $\mathrm{T} 2 \mathrm{P}=$ temperature/dual pressure probe. $\mathrm{CDS}=$ colleted delivery system. $\mathrm{BHA}=$ bottom-hole assembly. $\mathrm{CDT}=$ central daylight time. $\mathrm{SPM}=$ strokes per minute. 
Table T19. Event summary of T2P Deployment 7, Hole U1324B.

\begin{tabular}{rcl}
\hline & Time & \\
Event & $($ CDT $)$ & \\
\hline 1 & $15: 18: 00$ & Data logger started at 1 Hz \\
2 & $15: 56: 13$ & T2P on rig floor \\
3 & $16: 07: 34$ & Start lowering T2P downhole, pumps on \\
4 & $16: 15: 37$ & Stop at 511 mbsl, pumps off \\
5 & $16: 17: 21$ & Start lowering probe, pumps on \\
6 & $16: 20: 55$ & Stop at 761 mbsl, pumps off \\
7 & $16: 22: 48$ & Start lowering probe, pumps on \\
8 & $16: 26: 40$ & Stop at 1058 mbsl, pumps off \\
9 & $16: 30: 00$ & Start lowering probe \\
10 & $16: 33: 23$ & Stop at 1164 mbsl, pumps off \\
11 & $16: 40: 04$ & Start lowering probe to land in BHA \\
12 & $16: 44: 27$ & CDS lands in BHA; pumps off \\
13 & $16: 47: 23$ & Start penetration of T2P into sediment \\
14 & $16: 48: 41$ & End of T2P penetration; bit 1 m off bottom of hole \\
15 & $16: 52: 24$ & Raising BHA 2 m off bottom of hole \\
16 & $16: 58: 15$ & Pumping at 14 spm \\
17 & $17: 28: 50$ & Pulling T2P uphole slowly with wireline \\
18 & $17: 33: 15$ & CDS clear of BHA \\
19 & $17: 34: 00$ & Stop at 1058 mbsl, pumps off \\
20 & $17: 36: 23$ & Pulling T2P uphole slowly with wireline \\
21 & $17: 40: 42$ & Stop at 760 mbsl, pumps off \\
22 & $17: 42: 49$ & Pulling T2P uphole slowly with wireline \\
23 & $17: 46: 02$ & Stop at 511 mbsl, pumps off \\
24 & $17: 48: 12$ & Pulling T2P uphole slowly with wireline \\
25 & $17: 55: 35$ & Wireline disconnected from CDS \\
26 & $17: 56: 39$ & CDS retracted \\
27 & $17: 58: 10$ & CDS disconnected from spacer \\
28 & $17: 59: 55$ & Spacer disconnected from CDS \\
29 & $18: 01: 00$ & T2P out of pipe \\
30 & $18: 08: 18$ & Data downloaded from data logger \\
\hline & & \\
& & \\
& &
\end{tabular}

Notes: Depth $=117.8$ mbsf. Date $=21$ June 2005. T2P $=$ temperature/dual pressure probe. $C D S=$ colleted delivery system. $\mathrm{BHA}=$ bottom-hole assembly. $\mathrm{CDT}=$ central daylight time. $\mathrm{STM}=$ strokes per minute. 
Table T20. Event summary of T2P Deployment 8, Hole U1324B.

\begin{tabular}{rcl}
\hline & Time & \\
Event & (CDT) & \\
\hline 1 & $19: 28: 15$ & \multicolumn{1}{c}{ Data logger started at 1 Hz } \\
2 & $20: 45: 41$ & T2P on rig floor \\
3 & $20: 58: 19$ & Start lowering T2P downhole, pumps on \\
4 & $21: 08: 05$ & Stop at 511 mbsl, pumps off \\
5 & $21: 10: 10$ & Start lowering probe, pumps on \\
6 & $21: 14: 29$ & Stop at 761 mbsl, pumps off \\
7 & $21: 17: 00$ & Start lowering probe, pumps on \\
8 & $21: 21: 21$ & Stop at 1058 mbsl, pumps off \\
9 & $21: 23: 35$ & Start lowering probe \\
10 & $21: 27: 07$ & Stop at 1151 mbsl, pumps off \\
11 & $21: 32: 50$ & Start lowering probe \\
12 & $21: 34: 35$ & Stop at 1181 mbsl, pumps off \\
13 & $21: 38: 25$ & Start lowering probe \\
14 & $21: 43: 12$ & CDS lands in BHA; pumps off \\
15 & $21: 43: 58$ & Start penetration of T2P into sediment \\
16 & $21: 44: 49$ & End of T2P penetration; bit at bottom of hole \\
17 & $21: 45: 21$ & Raising BHA 1.5 m off bottom of hole \\
18 & $22: 16: 41$ & Pulling T2P uphole slowly with wireline \\
19 & $22: 18: 30$ & CDS clear of BHA \\
20 & $22: 20: 50$ & Stop at 1058 mbsl, pumps off \\
21 & $22: 23: 50$ & Pulling T2P uphole slowly with wireline \\
22 & $22: 27: 26$ & Stop at 761 mbsl, pumps off \\
23 & $22: 30: 25$ & Pulling T2P uphole slowly with wireline \\
24 & $22: 33: 40$ & Stop at 511 mbsl, pumps off \\
25 & $22: 36: 00$ & Pulling T2P uphole slowly with wireline \\
26 & $22: 42: 35$ & Wireline disconnected from CDS \\
27 & $22: 45: 08$ & CDS disconnected from spacer \\
28 & $22: 46: 30$ & Spacer disconnected from CDS \\
29 & $22: 47: 15$ & T2P out of pipe \\
30 & $23: 11: 00$ & Data downloaded from data logger \\
\hline & &
\end{tabular}

Notes: Depth $=136.3$ mbsf. Date $=21$ June 2005. T2P $=$ temperature/dual pressure probe. $\mathrm{CDS}=$ colleted delivery system. $\mathrm{BHA}=$ bottom-hole assembly. CDT = central daylight time.

Table T21. Event summary of T2P Deployment 9, Hole U1324B.

\begin{tabular}{rcl}
\hline Event & $\begin{array}{c}\text { Time } \\
(\text { CDT })\end{array}$ & \multicolumn{1}{c}{ Event } \\
\hline 1 & $08: 28: 29$ & Data logger started at 1 Hz \\
2 & $09: 57: 35$ & T2P on rig floor \\
3 & $10: 11: 43$ & Start lowering T2P downhole, pumps on \\
4 & $10: 28: 24$ & Stop at 1058 mbsl, pumps off \\
5 & $10: 33: 36$ & Start lowering probe \\
6 & $10: 45: 14$ & Stop at 1432 mbsl, pumps off \\
7 & $10: 49: 43$ & Start lowering probe \\
8 & $10: 53: 27$ & CDS lands in BHA; pumps off \\
9 & $10: 54: 10$ & Start penetration of T2P into sediment \\
10 & $10: 58: 39$ & End of T2P penetration; bit at bottom of hole \\
11 & $10: 59: 31$ & Raising BHA 2 m off bottom of hole \\
12 & $11: 40: 15$ & Pulling T2P uphole slowly with wireline \\
13 & $11: 48: 13$ & Stop at 1058 mbsl, pumps off \\
14 & $11: 51: 35$ & Pulling T2P uphole slowly with wireline \\
15 & $12: 01: 39$ & Wireline disconnected from CDS \\
16 & $12: 04: 35$ & CDS disconnected from spacer \\
17 & $12: 06: 10$ & Spacer disconnected from CDS \\
18 & $12: 08: 23$ & T2P out of pipe \\
19 & $12: 30: 00$ & Data downloaded from data logger \\
\hline
\end{tabular}

Notes: Depth $=368.0$ mbsf. Date $=23$ June 2005. T2P $=$ temperature/dual pressure probe. $\mathrm{CDS}=$ colleted delivery system. $\mathrm{BHA}=$ bottom-hole assembly. $\mathrm{CDT}=$ central daylight time. 
Table T22. Event summary of T2P Deployment 10, Hole U1324B.

\begin{tabular}{rcl}
\hline Event & $\begin{array}{c}\text { Time } \\
(\text { CDT })\end{array}$ & \\
\hline 1 & $16: 36: 20$ & \multicolumn{1}{c}{ Event } \\
2 & $17: 26: 10$ & T2P on rig floor \\
3 & $17: 57: 34$ & Start lowering T2P downhole, pumps on \\
4 & $18: 10: 58$ & Stop at 1058 mbsl, pumps off \\
5 & $18: 14: 18$ & Start lowering probe \\
6 & $18: 24: 55$ & CDS lands in BHA; pumps off \\
7 & $18: 27: 03$ & Start penetration of T2P into sediment \\
8 & $18: 31: 25$ & End of T2P penetration; bit at bottom of hole \\
9 & $18: 33: 20$ & Raising BHA 2.5 m off bottom of hole \\
10 & $19: 06: 01$ & Pulling T2P uphole slowly with wireline \\
11 & $19: 13: 40$ & Stop at 1058 mbsl, pumps off \\
12 & $19: 16: 47$ & Pulling T2P uphole slowly with wireline \\
13 & $19: 30: 04$ & Wireline disconnected from CDS \\
14 & $19: 37: 00$ & CDS disconnected from spacer \\
15 & $19: 39: 21$ & Spacer disconnected from CDS \\
16 & $19: 40: 11$ & T2P out of pipe \\
17 & $19: 59: 59$ & Data downloaded from data logger \\
\hline
\end{tabular}

Notes: Depth $=394.5$ mbsf. Date $=23$ June 2005. T2P $=$ temperature/dual pressure probe. $\mathrm{CDS}=$ colleted delivery system. $\mathrm{BHA}=$ bottom-hole assembly. $\mathrm{CDT}=$ central daylight time.

Table T23. Event summary of T2P Deployment 11, Hole U1324B.

\begin{tabular}{rcl}
\hline Event & $\begin{array}{c}\text { Time } \\
(\text { GMT })\end{array}$ & \multicolumn{1}{c}{ Event } \\
\hline 1 & $12: 02: 00$ & Data logger started at 1 Hz \\
2 & $12: 18: 13$ & T2P on rig floor \\
3 & $12: 31: 55$ & Start lowering T2P downhole, pumps on \\
4 & $12: 42: 00$ & Stop at 1068 mbsl, pumps off \\
5 & $12: 45: 46$ & Start lowering probe \\
6 & $12: 50: 23$ & Stop at 1510 mbsl, pumps off \\
7 & $12: 56: 38$ & Start lowering probe \\
8 & $12: 58: 11$ & CDS lands in BHA; pumps off \\
9 & $13: 14: 02$ & Pulling T2P uphole slowly with wireline \\
10 & $13: 25: 02$ & Stop at 1067 mbsl, pumps off \\
11 & $13: 28: 02$ & Pulling T2P uphole slowly with wireline \\
12 & $13: 34: 27$ & Wireline disconnected from CDS \\
13 & $13: 38: 21$ & CDS disconnected from spacer \\
14 & $13: 40: 15$ & Spacer disconnected from CDS \\
15 & $13: 46: 40$ & T2P out of pipe \\
16 & $14: 10: 36$ & Data downloaded from data logger \\
& &
\end{tabular}

Notes: Depth $=593.2$ mbsf. Date $=25$ June 2005. T2P $=$ temperature/dual pressure probe. $\mathrm{CDS}=$ colleted delivery system. $\mathrm{BHA}=$ bottom-hole assembly. GMT = Greenwich Mean Time. 
Table T24. Event summary of T2P Deployment 12, Hole U1324C.

\begin{tabular}{|c|c|c|}
\hline Event & $\begin{array}{l}\text { Time } \\
\text { (GMT) }\end{array}$ & Event \\
\hline 1 & & Data logger started at $1 \mathrm{~Hz}$ \\
\hline 2 & $10: 44: 26$ & $\mathrm{~T} 2 \mathrm{P}$ on rig floor \\
\hline 3 & $10: 52: 56$ & Start lowering T2P downhole, pumps on \\
\hline 4 & 11:09:00 & Stop at $491 \mathrm{mbsl}$, pumps off \\
\hline 5 & $11: 11: 37$ & Start lowering probe \\
\hline 6 & $11: 14: 13$ & Stop at $741 \mathrm{mbsl}$, pumps off \\
\hline 7 & $11: 19: 00$ & Stop at $1057 \mathrm{mbsl}$, pumps off \\
\hline 8 & $11: 22: 09$ & Stop at $1095 \mathrm{mbsl}$, pumps off \\
\hline 9 & $11: 28: 08$ & Start lowering probe \\
\hline 10 & $11: 29: 20$ & CDS lands in BHA; pumps off \\
\hline 11 & $11: 32: 50$ & Start penetration of $\mathrm{T} 2 \mathrm{P}$ into sediment \\
\hline 12 & $11: 40: 35$ & End of T2P penetration; bit on bottom of hole \\
\hline 13 & $11: 40: 36$ & Raising BHA $4.5 \mathrm{~m}$ off bottom of hole \\
\hline 14 & $12: 41: 05$ & Pulling T2P uphole slowly with wireline \\
\hline 15 & $12: 44: 52$ & Stop at $1057 \mathrm{mbsl}$, pumps off \\
\hline 16 & $12: 48: 00$ & Pulling T2P uphole slowly with wireline \\
\hline 17 & $12: 54: 09$ & Stop at $741 \mathrm{mbsl}$, pumps off \\
\hline 18 & $12: 56: 09$ & Pulling T2P uphole slowly with wireline \\
\hline 19 & $13: 00: 57$ & Stop at $491 \mathrm{mbsl}$, pumps off \\
\hline 20 & $13: 02: 57$ & Pulling T2P uphole slowly with wireline \\
\hline 21 & & Data downloaded from data logger \\
\hline
\end{tabular}

Notes: Depth $=50.0$ mbsf. Date $=26$ June 2005. T2P $=$ temperature/dual pressure probe. $\mathrm{CDS}=$ colleted delivery system. $\mathrm{BHA}=$ bottom-hole assembly. GMT $=$ Greenwich Mean Time.

Table T25. Event summary of T2P Deployment 13, Hole U1324C.

\begin{tabular}{ccl}
\hline Event & $\begin{array}{c}\text { Time } \\
(\mathrm{GMT})\end{array}$ & \\
\hline 1 & $14: 42: 47$ & Data logger started at 1 Hz \\
2 & $16: 18: 30$ & T2P on rig floor \\
3 & $16: 28: 42$ & Start lowering T2P downhole, pumps on \\
4 & $16: 44: 22$ & Stop at 741 mbsl, pumps off \\
5 & $16: 46: 30$ & Start lowering probe \\
6 & $16: 52: 33$ & Stop at 1057 mbsl, pumps off \\
7 & $16: 54: 39$ & Start lowering probe \\
8 & $17: 03: 38$ & CDS lands in BHA; pumps off \\
9 & $17: 04: 34$ & Start penetration of T2P into sediment \\
10 & $17: 05: 22$ & End of T2P penetration; bit 1 m off bottom of hole \\
11 & $17: 06: 00$ & Raising BHA 2 m off bottom of hole \\
12 & $18: 08: 10$ & Pulling T2P uphole slowly with wireline \\
13 & $18: 11: 22$ & Stop at 1057 mbsl, pumps off \\
14 & $18: 13: 30$ & Pulling T2P uphole slowly with wireline \\
15 & $18: 17: 18$ & Stop at 741 mbsl, pumps off \\
16 & $18: 19: 36$ & Pulling T2P uphole slowly with wireline \\
17 & $18: 22: 53$ & Stop at 491 mbsl, pumps off \\
18 & $18: 24: 29$ & Pulling T2P uphole slowly with wireline \\
19 & $18: 30: 32$ & Wireline disconnected from CDS \\
20 & $18: 34: 39$ & CDS disconnected from spacer \\
21 & $18: 36: 28$ & Spacer disconnected from CDS \\
22 & $18: 36: 28$ & T2P out of pipe \\
23 & & Data downloaded from data logger \\
\hline
\end{tabular}

Notes: Depth $=100.0$ mbsf. Date $=26$ June 2005. T2P $=$ temperature/dual pressure probe. $\mathrm{CDS}=$ colleted delivery system. $\mathrm{BHA}=$ bottom-hole assembly. GMT = Greenwich Mean Time. 
Table T26. Event summary of T2P Deployment 14, Hole U1324C.

\begin{tabular}{rll}
\hline Event & $\begin{array}{c}\text { Time } \\
(\text { GMT })\end{array}$ & \\
\hline 1 & & \multicolumn{1}{c}{ Event } \\
2 & $21: 28: 16$ & Stop at 491 mbsl, pumps off \\
3 & $21: 30: 16$ & Start lowering probe \\
4 & $21: 35: 17$ & Stop at 741 mbsl, pumps off \\
5 & $21: 37: 29$ & Start lowering probe \\
6 & $21: 43: 36$ & Stop at 1057 mbsl, pumps off \\
7 & $21: 45: 49$ & Start lowering probe \\
8 & $21: 49: 31$ & Stop at 1195 mbsl, pumps off \\
9 & $21: 52: 07$ & Start lowering probe \\
10 & $21: 55: 00$ & CDS lands in BHA; pumps off \\
11 & $21: 56: 30$ & Start penetration of T2P into sediment \\
12 & $21: 57: 25$ & End of T2P penetration; bit on bottom of hole \\
13 & $21: 57: 44$ & Raising BHA 2.5 m off bottom of hole \\
14 & $23: 02: 47$ & Pulling T2P uphole slowly with wireline \\
15 & $23: 09: 44$ & Stop at 1057 mbsl, pumps off \\
16 & $23: 14: 53$ & Pulling T2P uphole slowly with wireline \\
17 & $23: 18: 53$ & Stop at 741 mbsl, pumps off \\
18 & $23: 21: 27$ & Pulling T2P uphole slowly with wireline \\
19 & $23: 24: 07$ & Stop at 491 mbsl, pumps off \\
20 & $23: 26: 07$ & Pulling T2P uphole slowly with wireline \\
21 & & Data downloaded from data logger \\
\hline & &
\end{tabular}

Notes: Depth $=150.0$ mbsf. Date $=26$ June 2005. T2P $=$ temperature/dual pressure probe. $\mathrm{CDS}=$ colleted delivery system. $\mathrm{BHA}=$ bottom-hole assembly. GMT $=$ Greenwich Mean Time.

Table T27. Event summary of T2P Deployment 15, Hole U1324C.

\begin{tabular}{ccl}
\hline Event & $\begin{array}{c}\text { Time } \\
(\text { GMT })\end{array}$ & \\
\hline 1 & $0: 49: 19$ & Data logger started at 1 Hz \\
2 & $1: 56: 31$ & T2P on rig floor \\
3 & $2: 09: 04$ & Start lowering T2P downhole, pumps on \\
4 & $2: 17: 40$ & Stop at 491 mbsl, pumps off \\
5 & $2: 19: 52$ & Start lowering probe \\
6 & $2: 24: 36$ & Stop at 741 mbsl, pumps off \\
7 & $2: 26: 51$ & Start lowering probe \\
8 & $2: 32: 55$ & Stop at 1057 mbsl, pumps off \\
9 & $2: 35: 34$ & Start lowering probe \\
10 & $2: 40: 23$ & Stop at 1245 mbsl, pumps off \\
11 & $2: 43: 42$ & Start lowering probe \\
12 & $2: 47: 37$ & CDS lands in BHA; pumps off \\
13 & $2: 48: 02$ & Start penetration of T2P into sediment \\
14 & $2: 49: 28$ & End of T2P penetration; bit 1 m off bottom of hole \\
15 & $2: 52: 20$ & Raising BHA 4.5 m off bottom of hole \\
16 & $3: 53: 17$ & Pulling T2P uphole slowly with wireline \\
17 & $3: 56: 56$ & Stop at 1057 mbsl, pumps off \\
18 & $3: 59: 23$ & Pulling T2P uphole slowly with wireline \\
19 & $4: 02: 52$ & Stop at 741 mbsl, pumps off \\
20 & $4: 05: 07$ & Pulling T2P uphole slowly with wireline \\
21 & $4: 07: 56$ & Stop at 491 mbsl, pumps off \\
22 & $4: 10: 05$ & Pulling T2P uphole slowly with wireline \\
23 & $4: 15: 55$ & Wireline disconnected from CDS \\
24 & $4: 17: 54$ & CDS disconnected from spacer \\
25 & $4: 19: 43$ & Spacer disconnected from CDS \\
26 & $4: 21: 51$ & T2P out of pipe \\
27 & & Data downloaded from data logger \\
\hline & &
\end{tabular}

Notes: Depth $=200.0$ mbsf. Date $=27$ June 2005. T2P $=$ temperature/dual pressure probe. $\mathrm{CDS}=$ colleted delivery system. $\mathrm{BHA}=$ bottom-hole assembly. GMT $=$ Greenwich Mean Time. 
Table T28. Event summary of T2P Deployment 16, Hole U1324C.

\begin{tabular}{rrl}
\hline Event & $\begin{array}{c}\text { Time } \\
(\text { GMT })\end{array}$ & \\
\hline 1 & & \multicolumn{1}{c}{ Event } \\
2 & $11: 18: 00$ & Start logger started at 1 Hz \\
3 & $11: 37: 22$ & Stop at 491 mbsl, pumps off \\
4 & $11: 39: 35$ & Start lowering probe \\
5 & $11: 43: 21$ & Stop at 741 mbsl, pumps off \\
6 & $11: 45: 21$ & Start lowering probe \\
7 & $11: 49: 33$ & Stop at 1057 mbsl, pumps off \\
8 & $11: 52: 30$ & Start lowering probe \\
9 & $11: 57: 30$ & Stop at 1345 mbsl, pumps off \\
10 & $11: 59: 30$ & Start lowering probe \\
11 & $12: 05: 15$ & Start penetration of T2P into sediment \\
12 & $12: 17: 12$ & End of T2P penetration; bit on bottom of hole \\
13 & $12: 22: 15$ & Raising BHA 4 m off bottom of hole \\
14 & $13: 47: 24$ & Pulling T2P uphole slowly with wireline \\
15 & $13: 54: 09$ & Stop at 1057 mbsl, pumps off \\
16 & $13: 57: 00$ & Pulling T2P uphole slowly with wireline \\
17 & $14: 02: 33$ & Stop at 741 mbsl, pumps off \\
18 & $14: 04: 30$ & Pulling T2P uphole slowly with wireline \\
19 & $14: 09: 10$ & Stop at 491 mbsl, pumps off \\
20 & $14: 11: 10$ & Pulling T2P uphole slowly with wireline \\
21 & & Data downloaded from data logger \\
\hline & &
\end{tabular}

Notes: Depth $=300.0$ mbsf. Date $=27$ June 2005. T2P $=$ temperature/dual pressure probe. $\mathrm{BHA}=$ bottom-hole assembly. $\mathrm{GMT}=\mathrm{Greenwich}$ Mean Time. 